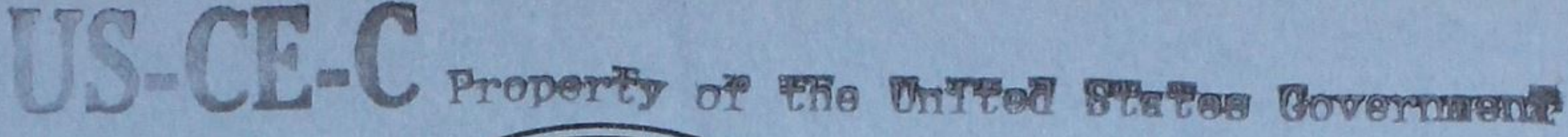

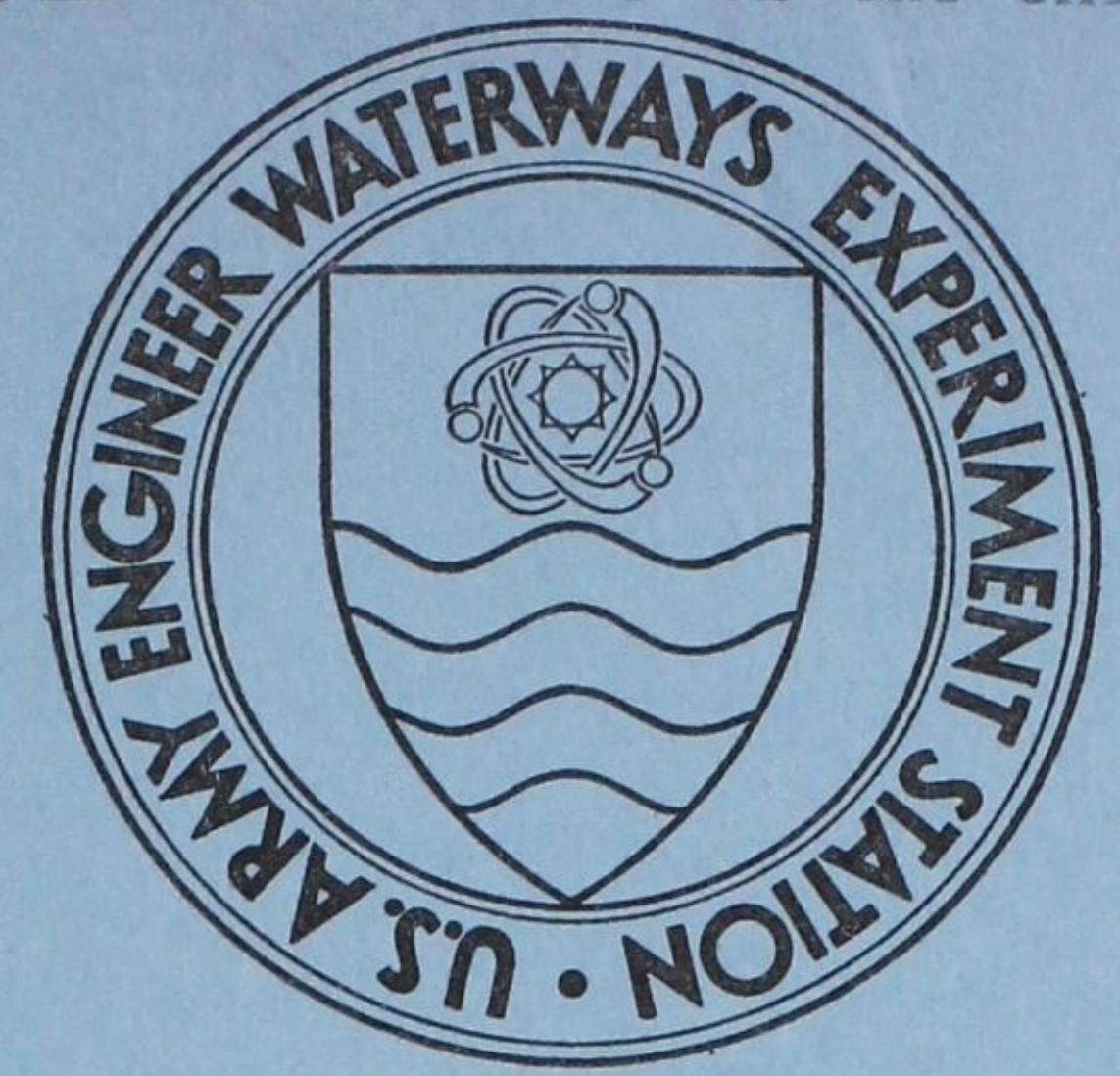

TECHNICAL REPORT S-72-5

\title{
AN EVALUATION OF AN EXISTING PROCEDURE FOR DETERMINING SHEAR MODULI AT DEPTHS BY IN SITU VIBRATORY TECHNIQUE
}

by

J. Fowler

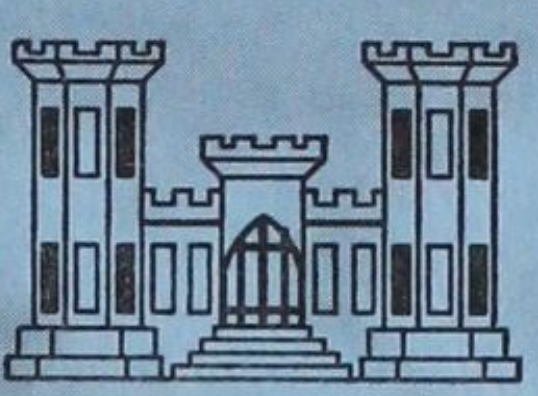

TECHNICAL INFORMATION CENTER

US ARMY ENGINEER WATERWAYS EXPERIMENT STATION

VICKSBURG, MISSISSIPPI

April 1972

Conducted by U. S. Army Engineer Waterways Experiment Station, Vicksburg, Mississippi 


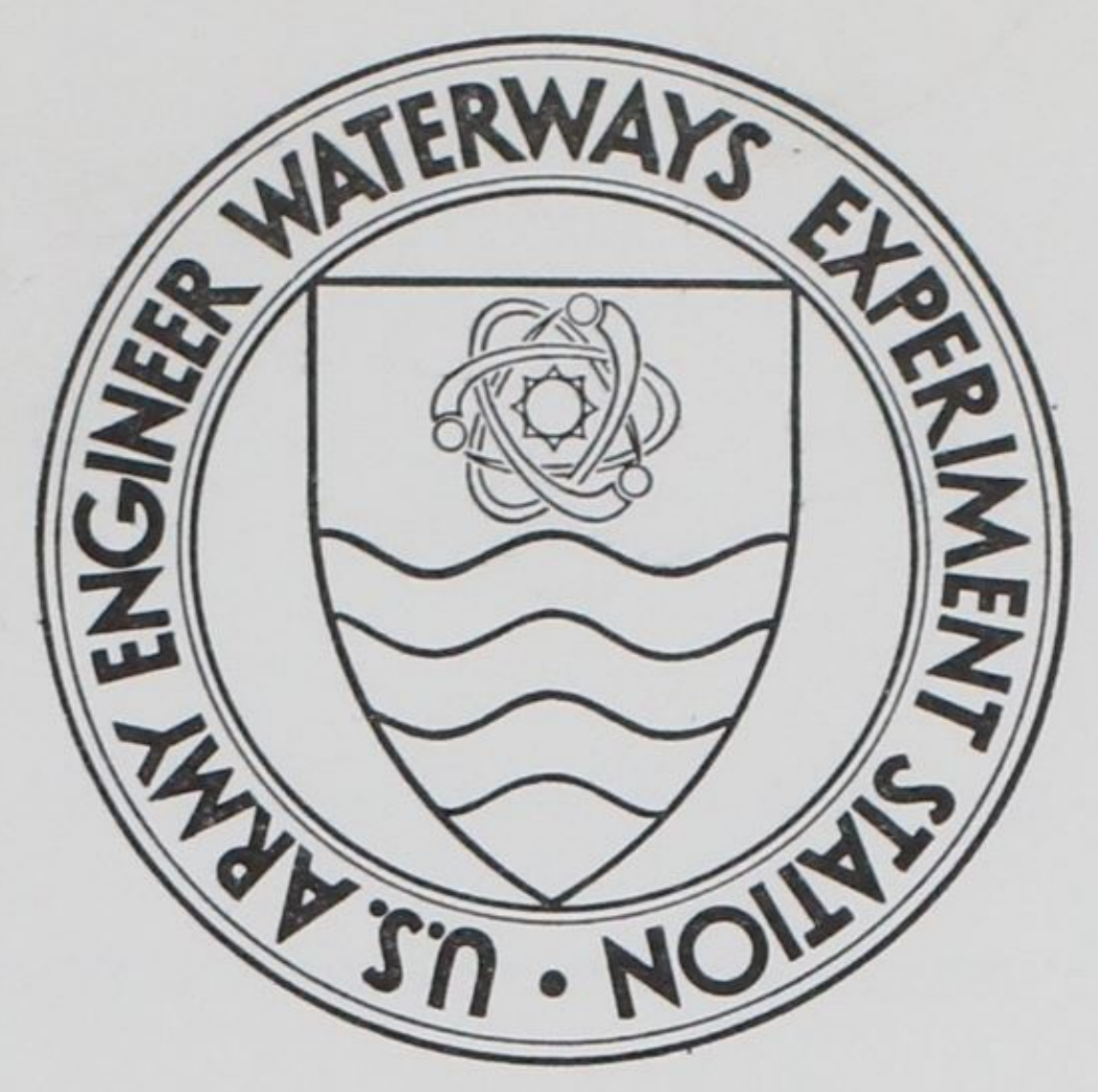

TECHNICAL REPORT S-72-5

\section{AN EVALUATION OF AN EXISTING PROCEDURE FOR DETERMINING SHEAR MODULI AT DEPTHS BY IN SITU VIBRATORY TECHNIQUE \\ by \\ J. Fowler}

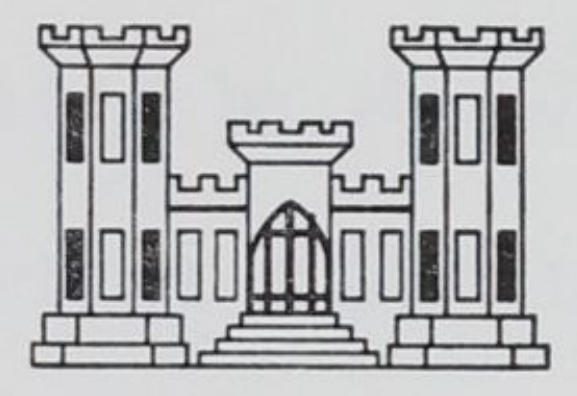

April 1972

Conducted by U. S. Army Engineer Waterways Experiment Station, Vicksburg, Mississippi 
FOREWORD

The investigation described herein was performed by the U. S. Army Engineer Waterways Experiment Station (WES) for the Office, Chief of Engineers, in accordance with the Instructions and Outlines for Development of Engineering Criteria for FrY66 - FY68. This report describes the tests conducted at WES during March and April 1966.

Engineers of the Soil Dynamics Branch, WES, actively engaged in data collection, analysis, and report phases of this study were Messrs. R. W. Cunny, Z. B. Fry, R. F. Ballard, Jr., D. R Casagrande and J. Fowler. The work was done under the general supervision of Mr. W. J. Turnbull, Chief (retired), and J.P. Sale, Chief, and Mr. A. A. Maxwell (deceased), Assistant Chief, and R. G. Ahlvin, Assistant Chief, Soils Division.

The report was prepared by Mr. Jack Fowler, and is essentially a thesis submitted in partial fulfillment of the requirements for the degree of Master of Science in Civil Engineering to the Mississippi State University, State College, Mississippi.

Directors of the Waterways Experiment Station during the preparation and publication of this report were COL John R. Oswalt, $\mathrm{CE}$, COL Levi A. Brown, CE, and COL Ernest D. Peixotto, CE. Technical Directors were Mr. J. B. Tiffany and Mr. F. R. Brown. 


\section{ACKNOWLEDGEMENTS}

The study presented in this thesis is an evaluation of the use of surface-induced vibrations to determine the dynamic soil properties at depth. This investigation was performed at the Waterways Experiment Station (WES) for the Office, Chief of Engineers, in accordance with the Instructions and Outlines for the Development of Engineering Criteria for FY 66 - FY 68. The author is grateful to the personnel and supervisors of the WES for allowing him to perform this study, as well as for their guidance and pertinent comments. Particular appreciation is expressed to Messrs. R. W. Cunny, Z. B. Fry, Jr., R. F. Ballard, Jr., and D. R. Casagrande. The author extends deep appreciation to Mr. H. C. Greer, III, Electrical Engineer, for his suggestions and assistance in assembling and operating the electronic instrumentation used in this study and to Mrs. Dorothy Booth and SP4 R. G. Guernsey for data reduction and preparation of report material. In addition, the writer extends his gratitude to his faculty advisor, Professor R. M. Scholtes, and the remainder of his graduate committee including Professor M. B. Clisby and Assistant Professor E. Springer. The work of Mrs. Gwendolyn W. Reid in assisting with the style and format and typing of the manuscript was invaluable. Appreciation is also extended to Mrs. Modell Holloway for her assistance in typing. 


\section{TABLE OF CONTENTS}

\section{$\underline{\text { Page }}$}

ACKNOWLEDGMENTS

LIST OF TABLES

vi

LIST OF FIGURES

vii

CHAPTER I. INTRODUCTION

1.1 Background

1.2 Purpose and Scope of Investigation

CHAPTER II. PRELIMINARY INVESTIGATION

2.1 Theoretical Basis

2.2 Location of Tests

CHAPTER III. TESTS CONDUCTED

3.1 Test Plan

3.2 Tests Performed and Instrumentation 8

3.2.1 Tests

3.2.2 Instrumentation

CHAPTER IV. TEST RESULTS

4.1 Surface Measurements - Group A

4.1.1 Procedure and Operational Data

4.1.2 Measurements

4.2 Subsurface Measurements - Group B

4.2.1 Procedure and Operational Data

4.2.2 Measurements

4.3 Subsurface Measurements - Group C 
$\underline{\text { Page }}$

4.3.1 Procedure and Operational Data 22

$\begin{array}{lll}4.3 .2 & \text { Measurements } & 22\end{array}$

$\begin{array}{llll}\text { CHAPTER V ANALYS OF RESULTS } & 25\end{array}$

5.1 Conventional Soil Tests 25

5.2 Dynamic Laboratory and Field Moduli 26

5.3 Phase-Velocity Measurements 28

5.4 Particle-Velocity Measurements 28

CHAPTER VI CONCLUSIONS AND RECOMMENDATIONS 35

6.1 Conclusions $\quad 35$

6.2 Recommendations 36

$\begin{array}{ll}\text { ABS TRACT } & 37\end{array}$

APPENDIX A. DETERMINATION OF ELASTIC CHARACTERISTICS OF SOILS BY DYNAMIC FIELD TECHNIQUES 40

APPENDIX B. CONVENTIONAL SOILS TESTS 47

APPENDIX C. DYNAMIC LABORATORY AND FIELD TESTS 74

APPENDIX D. PEAK PARTICLE-VELOCITY MEASUREMENTS 88

APPENDIX E. TABULATION OF PHASE-VELOCITY MEASUREMENTS BETWEEN VERTICAL TRANSDUCERS AT VARIOUS DEPTHS 101

APPENDIX E. PLOTS OF PARTICLE VELOCITY AT VARIOUS DEPTHS 110

$\begin{array}{ll}\text { REFERENCES AND BIBLIOGRAPHY } & 122\end{array}$ 


\section{LIS T OF TABLES}

$\underline{T a b l e}$

$\underline{\text { Page }}$

$1 \quad$ Torsional and Vertical Forces Generated by Variable-Mass Hydraulic Vibrator

B-1 Unconfined Compression Tests

B-2 Triaxial Q Tests

B-3 Direct Shear Tests 53

C-1 In Situ Soil Tests, WES Test Area 81

D-1 Surface Measurements of Peak Particle Velocity 89

D-2 Subsurface Measurements of Peak Particle Velocity Transducers at Various Depth

D-3 Subsurface Measurements of Peak Particle Velocity, Major Transducers at Various Depths in Hole 1 


\section{LIST OF FIGURES}

Figure

$\underline{\text { Page }}$

1 Location of Controlled Test Section

2 Test Site Profile

3 Eccentric Rotating Mass Vibrator and Instrumentation Van

$4 \quad$ Typical Oscillogram

Record Test 5, $25 \mathrm{~Hz}$

5 Velocity Transducers and Canister

6 Group A Test Layout

7 Test Group B

Series III-V

8 Test Group B

Series VI-VIII

9 Test Group C

Series IX-X

10 Comparison of Strength Parameters

11 Comparison of Phase Velocities

I2 Vertical Particle Velocity Ratio versus Depth for Rayleigh Wave

13 Radial Particle Velocity Ratio versus Depth for Rayleigh Wave

B-1 Gradation Curves

B-2 Standard Penetration Resistance and Water Content versus Depth

B-3 Test Site Profile

B-4 Plasticity Chart

B-5 Unconfined Compression Test Report 
B-6 Unconfined Compression Test Report 59

B-7 Unconfined Compression Test Report 60

B-8 Unconfined Compression Test Report 61

B-9 Unconfined Compressive Strength versus Depth 62

B-10 Triaxial Compression Test Report 63

B-11 Triaxial Compression Test Report 64

B-12 Triaxial Compression Test Report 65

B-13 Triaxial Compression Test Report 66

B-14 Triaxial Compression Test Report 67

B-15 Triaxial Compression Test Report 68

B-16 Direct Shear Test Report 69

B-17 Direct Shear Test Report 70

B-18 Direct Shear Test Report 71

B-19 Direct Shear Test Report 72

B-20 Shear Strength versus Depth 73

C-1 Laboratory Shear and Compression Modulus
versus Depth and Soil Profile

C-2 Test Layjout 84

C-3 Typical Refraction Seismic Traverse 85

C-4 Shear Velocity versus Depth 86

C-5 Shear and Compression Modulus versus Depth 87

E-1 Phase Velocity of Vertical Components at $15 \mathrm{~Hz}$ Frequency 
E-2 Phase Velocity of Vertical Components at $20 \mathrm{~Hz}$ Frequency

E-3 Phase Velocity of Vertical Components at $25 \mathrm{~Hz}$ Frequency

E-4 Phase Velocity of Vertical Components at $30 \mathrm{~Hz}$ Frequency

E-5 Phase Velocity of Vertical Components at $35 \mathrm{~Hz}$ Frequency

E-6 Phase Velocity of Vertical Components at $40 \mathrm{~Hz}$ Frequency

E-7 Phase Velocity of Vertical Components at $45 \mathrm{~Hz}$ Frequency

E-8 Phase Velocity of Vertical Components at $50 \mathrm{~Hz}$ Frequency

F-1 Particle Velocity at Various Depths Holes 1-5, Frequency $15 \mathrm{~Hz}$

F-2 Particle Velocity at Various Depths Holes 1-5, Frequency $20 \mathrm{~Hz}$

F-3 Particle Velocity at Various Depths Holes 1-5, Frequency $25 \mathrm{~Hz}$

F-4 Particle Velocity at Various Depths Holes 1-5, Frequency $30 \mathrm{~Hz}$

F-5 Particle Velocity at Various Depths Holes 1-5, Frequency $35 \mathrm{~Hz}$

F-6 Particle Velocity at Various Depths Holes 1-5, Frequency $40 \mathrm{~Hz}$

F-7 Particle Velocity at Various Depths Holes 1-5, Frequency $45 \mathrm{~Hz}$

F-8 Particle Velocity at Various Depths Holes 1-5, Frequency $50 \mathrm{~Hz}$ 
F-9 Vertical Particle Velocity versus Depth

F-10 Radial Particle Velocity versus Depth

F-11 Transverse Particle Velocity versus Depth 


\section{INTRODUCTION}

\subsection{Background}

The investigation described herein was directed toward evaluation of the use of dynamic test procedures for the determination of dynamic in situ soil characteristics - specifically to evaluate the concept that the velocity determined from propagation of a surface wave is applicable to a depth of equal to one half of the wavelength. The U. S. Army Engineer Waterways Experiment Station (WES) has conducted numerous foundation investigations using dynamic techniques to determine the characteristics of subsurface materials. The details of the dynamic test procedure are presented in Appendix A. Subsequently, the procedure was incorporated in Engineer Manual 1110345-310, "Engineering and Design, Foundations Subjected to Vibratory Loads." This manual is used by all elments of the Corps of Engineers responsible for the design of military structures subjected to dynamic loads.

\subsection{Purpose and Scope of Investigation}

The purpose of this investigation was to determine the validity of the procedure described in Appendix A. Tests were conducted in an area where soil characteristics were considered to be uniform in both the horizontal and vertical planes. The tests included the determination of phase velocity between a controlled vibratory source and selected points on the surface and at various depths for a range of force and frequency input. In addition, the amplitude of motion 
(particle velocity) and wave-shape characteristics were determined at the selected distances and depths for measurements made in vertical, radial, and transverse directions. The data obtained were compared to results of dynamic in situ tests conducted in the same area and with theoretical dispersion or attenuation of surface waves with distance and depth in a homogeneous medium to evaluate the concept of velocity determined from the surface wave being applicable to a depth equal to one half of the wavelength. 


\section{PRELIMINARY INVESTIGATION}

\subsection{Theoretical Basis}

A solid that is in equilibrium generally requires 36 elastic constants to describe the stress-strain relations. For an isotropic body, the number of elastic constants reduces to two, and these may be taken to be the Lamé constants $\lambda$ and $G$, or the shear and compression moduli $\mathrm{E}$ and $\mathrm{G}$, or even the shear-wave and compression-wave $\mathrm{v}_{\mathrm{s}}$ and $\mathrm{v}_{\mathrm{p}}$. Assuming that the ground at the WES test site is adequately represented by an isotropic elastic solid, and one of the purposes of this work is to determine $E$ and G as a function of depth by a vibratory technique.

The two elastic parameters describe the linear relation between shear stress and shear strain and between pressure and simple compresion. The existence of two independent elastic constants implies that for an infinite isotropic elastic solid, there are two fundamental and independent types of wave motion called shear waves and compression waves. Any wave motion is associated with a time-dependent displacement of the particles of the solid. A wave for which the particle displacement is in the tangent plane of the wave front is called a shear wave or S-wave. Historically the $\mathrm{S}$ refers to "secondary" arrivals on seismograph records of earthquakes. When the time-dependent displacement is perpendicular to the wave front, the waves are called compression waves or P-waves. The designation P refers to "primary" arrivals on earthquake seismograph records. 
S-waves are not propagated in liquids because liquids do not sustain a shearing strain, while $\mathrm{P}$-waves are propagated in liquids and solids. The phase velocity of $\mathrm{S}-$ and $\mathrm{P}$-waves is given by:

$$
\begin{aligned}
& v_{s}=\sqrt{\frac{G}{\rho}} \\
& v_{p}=\sqrt{\frac{\lambda+2 G}{\rho}}
\end{aligned}
$$

where

$$
\rho=\text { mass density of soil }
$$

These expressions are only valid for infinite elastic media. If free surfaces are present, such as in the case of rods or plates, then different expressions for the P-wave velocity must be used.

When a free surface is present on a large elastic body, it is possible to have another kind of elastic wave propagation that has characteristics of both $\mathrm{P}$ - and S-waves (mainly S-waves) but which has the property of attenuating with depth and propagating along the surface. P- and S-waves propagate downward as well as in a horizontal direction. Surface waves with a vertical and a radial particle displacement producing a retrograde elliptical motion in time are called Rayleigh waves; while surface waves with a particle displacement that is transverse to the direction of propagation are called Love waves. Only Rayleigh waves will be discussed in this thesis.

If the ground is homogeneous, the phase velocity of the Rayleigh waves is independent of frequency and depends only on the elastic 
constants of the ground. For example if Poisson's ratio $v$ has the value of $1 / 4$, then the Rayleigh wave velocity $v_{R}$ equals $0.92 v_{S}$. It can be shown that in general $v_{R} \lesssim v_{S}$. If the elastic half-space is nonhomogeneous, the Rayleigh wave phase velocity is a function of frequency. This phenomenon of the velocity depending on the frequency is called dispersion, and the material in question is said to be dispersive. If the phase velocity is an increasing function of the wavelength, the situation is called normal dispersion. Such a situation occurs when the shear modulus is an increasing function of depth in an elastic half-space. If the shear modulus decreases with depth (such as in the case of a highway pavement overlying a soil base), the Rayleigh wave phase velocity is a decreasing function of wavelength and is referred to as the case of anomalous dispersion. The WES test site is a good example of normal dispersion. The calculation of a dispersion curve giving $v_{R}(\lambda)$ involves the solution of the wave equation, which attenuates with depth and which satisfies the boundary conditions of zero stress at the free surface. This calculation can be quite involved for nonhomogeneous media. For homogeneous media, theory shows that the Rayleigh wave phase velocity is always less than the shear-wave velocity; in fact, $0.875 \mathrm{v}_{\mathrm{S}}<\mathrm{v}_{\mathrm{R}}<0 / 955 \mathrm{v}_{\mathrm{S}}$ for the full variation of Poisson's ratio $0<v<1 / 2$. Experimental data taken by the WES shows that for the case of normal dispersion, the shape of the dispersion curve is very similar to that of shear-wave velocity versus depth curve. The possibility, therefore, arises that for the 
case of normal dispersion, it may be possible to reproduce the shearwave velocity versus depth curve from the dispersion curve by taking $v_{R} \sim v_{S}$ and assuming the depth to be a simple multiple of the wavelength. Empirically, we find that such a factor does exist and has the value $1 / 2$, so that depth $=1 / 2$ wavelength may be taken as an experimentally verified approximation. In this way, the shear modulus is determined as a function of depth from an experimentally determined dispersion curve.

\subsection{Location of Tests}

The site selected for the investigation was a level area on the WES reservation where the turf and top soil had been removed for previous studies (figure 1). Although considerable information was available on general characteristics of the material at the site, a more detailed investigation was deemed necessary to better define the area. Borings were made in the area to obtain samples for both conventional and dynamic laboratory tests. In addition, refraction seismic and vibratory traverses were conducted at the site in accordance with the procedures presented in Appendix A. Details and results of the conventional soils tests conducted are presented in Appendix B; the dynamic laboratory and field tests are reported in Appendix C. 


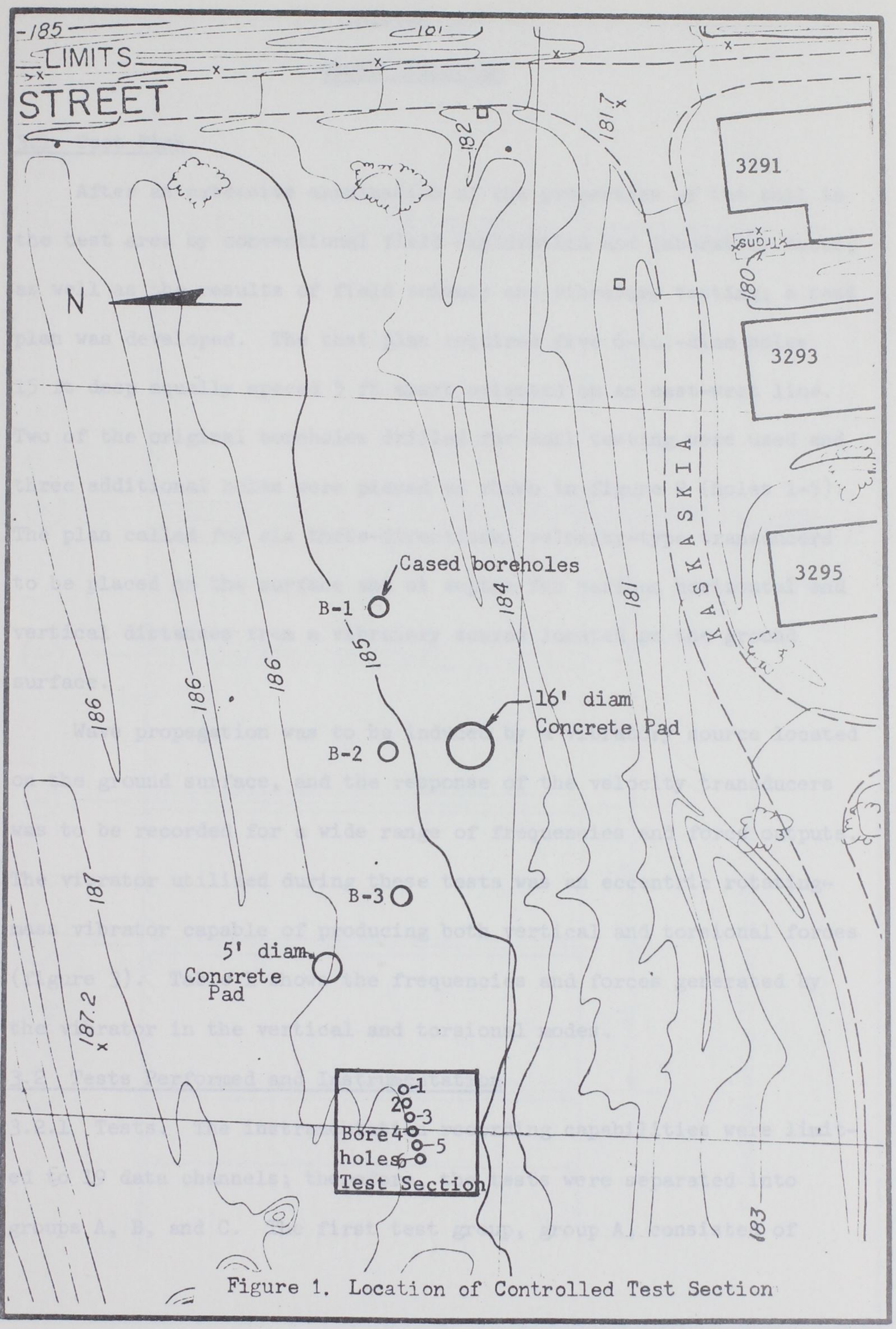




\section{TESTS CONDUCTED}

\subsection{Test Plan}

After an extensive examination of the properties of the soil in the test area by conventional field exploration and laboratory tests, as well as the results of field seismic and vibratory testing, a test plan was developed. The test plan required five 6-in.-diam holes $15 \mathrm{ft}$ deep equally speced $5 \mathrm{ft}$ apart oriented on an east-west line. Two of the original boreholes drilled for soil testing were used and three additional holes were placed as shown in figure 2 (holes 1-5). The plan called for six three-directional velocity-type transducers to be placed on the surface and at depths for various horizontal and vertical distances from a vibratory source located on the ground surface.

Wave propagation was to be induced by a vibratory source located on the ground surface, and the response of the velocity transducers was to be recorded for a wide range of frequencies and force outputs. The vibrator utilized during these tests was an eccentric rotatingmass vibrator capable of producing both vertical and torsional forces (figure 3). Table 1 shows the frequencies and forces generated by the vibrator in the vertical and torsional modes.

\subsection{Tests Performed and Instrumentation}

3.2.1 Tests. The instrumentation recording capabilities were limited to 19 data channels; therefore, the tests were separated into groups A, B, and C. The first test group, group A, consisted of 


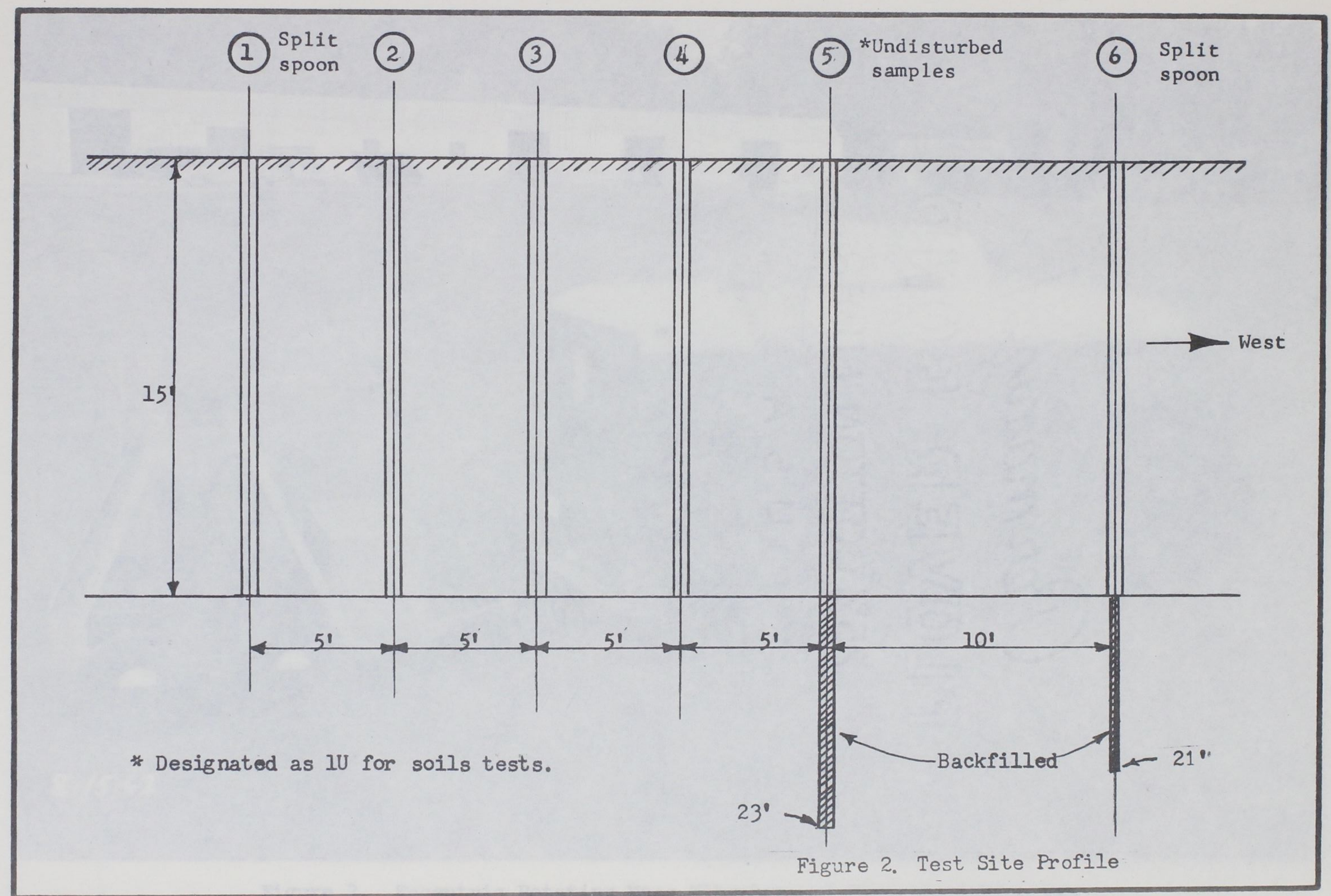




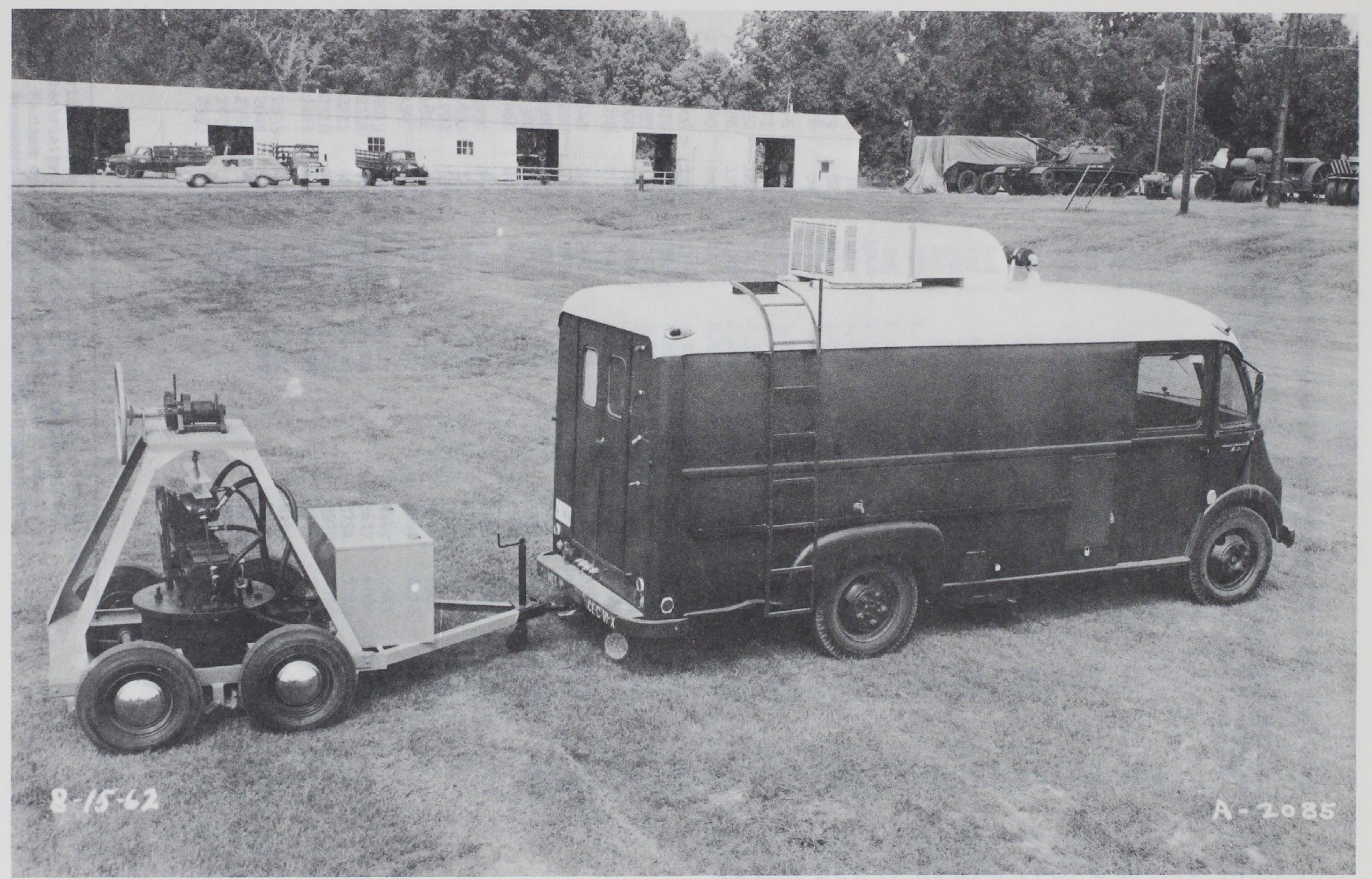

Figure 3. Eccentric Rotating Mass Vibrator and Instrumentation Van 
Table 1

Torsional and Vertical Forces Generated by Varlable-Mass Hydraulic Vibrator

\begin{tabular}{|c|c|c|c|c|c|c|c|c|c|c|}
\hline \multirow{3}{*}{$\begin{array}{c}\text { Fre- } \\
\text { quency } \\
\mathrm{Hz} \\
\end{array}$} & \multicolumn{5}{|c|}{ Torsional Mode* } & \multicolumn{5}{|c|}{ Vertical Mode* } \\
\hline & \multicolumn{5}{|c|}{ Total Wt of Eccentric Masses, Ib** } & \multicolumn{5}{|c|}{ Total Wt of Eccentric Masses, lb** } \\
\hline & 5.00 & 9.60 & 14.48 & 19.00 & 40.00 & 5.00 & 9.60 & 14.48 & 19.00 & 40.00 \\
\hline 1 & 1.2 & 2.3 & 3.5 & 4.6 & $9 \cdot 7$ & 2.1 & 4.0 & 6.0 & $7 \cdot 9$ & 16.6 \\
\hline 2 & 4.8 & 8.1 & 14.0 & 18.4 & 38.7 & 8.3 & 13.9 & 24.0 & 31.5 & 66.2 \\
\hline 3 & 10.7 & 20.6 & 31.1 & 40.7 & 85.8 & 18.4 & 35.3 & 53.2 & 69.8 & 147 \\
\hline 4 & 19.0 & 36.6 & 55.1 & 72.4 & 152 & 32.6 & 62.6 & 94.4 & 124 & 261 \\
\hline 5 & 29.8 & 57.2 & 86.4 & 113 & 238 & 51.0 & 97.9 & 148 & 194 & 408 \\
\hline 6 & 42 & 82 & 124 & 162 & 343 & 73.5 & 141 & 213 & 279 & 588 \\
\hline 7 & 58 & 112 & 169 & 221 & 467 & 100 & 192 & 290 & 380 & 801 \\
\hline 8 & 76 & 146 & 220 & 289 & 609 & 130 & 250 & 378 & 496 & 1,043 \\
\hline 9 & 96 & 185 & 279 & 366 & 773 & 165 & 317 & 478 & 627 & 1,321 \\
\hline 10 & 119 & 228 & 345 & 453 & 955 & 204 & 392 & 591 & 776 & 1,634 \\
\hline 11 & 144 & 277 & 418 & 546 & 1,153 & 247 & 475 & 716 & 939 & 1,977 \\
\hline 12 & 171 & 330 & 497 & 653 & 1,373 & 294 & 565 & 852 & 1,118 & 2,354 \\
\hline 13 & 201 & 386 & 582 & 766 & 1,610 & 345 & 662 & 998 & 1,310 & 2,758 \\
\hline 14 & 233 & 448 & 676 & 888 & 1,868 & 400 & 768 & 1,158 & 1,519 & 3,199 \\
\hline 15 & 268 & 515 & 778 & 1, & 2,146 & 459 & 882 & 1,330 & 1,746 & 3,675 \\
\hline 16 & 305 & 586 & 885 & 1,160 & 2,442 & 523 & 1004 & 1,514 & 1,986 & 4,182 \\
\hline 17 & 344 & 662 & 1000 & 1,310 & 2,757 & 590 & 1134 & 1,709 & 2,243 & 4,722 \\
\hline 18 & 386 & 742 & 1120 & 1,468 & 3,088 & 661 & 1269 & 1,914 & 2,512 & 5,288 \\
\hline 19 & 429 & 827 & 1245 & 1,634 & 3,440 & 736 & 1414 & 2,133 & 2,799 & 5,892 \\
\hline 20 & 476 & 916 & 1380 & 1,812 & 3,814 & 816 & 1568 & 2,364 & 3,103 & 6,532 \\
\hline 21 & 526 & 1010 & 1525 & 1,998 & 4,207 & 901 & 1730 & 2,608 & 3,422 & 7,205 \\
\hline 22 & 577 & 1110 & 1671 & 2,193 & 4,618 & 989 & 1899 & 2,863 & 3,756 & 7,909 \\
\hline 23 & 630 & 1210 & 1825 & 2,394 & 5,042 & 1079 & 2072 & 3,125 & 4,101 & 8,634 \\
\hline 24 & 686 & 1320 & 1987 & 2,608 & 5,491 & 1175 & 2257 & 3,404 & 4,467 & 9,404 \\
\hline 25 & 745 & 1430 & 2157 & 2,831 & 5,960 & 1276 & 2450 & $3 ; 694$ & 4,848 & 10,207 \\
\hline 26 & 806 & 1550 & 2334 & 3,062 & 6,447 & 1380 & 2651 & 3,997 & 5,244 & \\
\hline 27 & 870 & 1670 & 2518 & 3,304 & 6,957 & 1489 & 2860 & 4,312 & 5,658 & \\
\hline 28 & 935 & 1794 & 2705 & 3,550 & 7,474 & 1600 & 3072 & 4,633 & 6,079 & \\
\hline 29 & 1000 & 1924 & 2902 & 3,808 & 8,018 & 1716 & 3296 & 4,970 & 6,522 & \\
\hline 30 & 1070 & 2060 & 3107 & 4,077 & 8,584 & 1837 & 3529 & 5,321 & 6,982 & \\
\hline 31 & 1145 & 2200 & 3318 & 4,354 & 9,167 & 1962 & 3768 & 5,682 & 7,456 & \\
\hline 32 & 1220 & 2345 & 3536 & 4,640 & 9,769 & 2091 & 4016 & 6,055 & 7,946 & \\
\hline 33 & 1300 & 2491 & 3757 & 4,930 & 10.381 & 2222 & 4267 & 6,434 & 8,443 & \\
\hline 34 & 1380 & 2646 & 3989 & 5,235 & & 2359 & 4531 & 6,832 & 8,965 & \\
\hline 35 & 1460 & 2804 & 4228 & 5,548 & & 2500 & 4802 & 7,241 & 9,501 & \\
\hline 36 & 1550 & 2967 & 4474 & 5,871 & & 2646 & 5081 & 7,662 & 10,054 & \\
\hline 37 & 1633 & 3134 & 4727 & 6,203 & & 2796 & 5368 & 8,095 & & \\
\hline 38 & 1721 & 3304 & 4983 & 6,539 & & 2947 & 5659 & 8,533 & & \\
\hline 39 & 1812 & 3481 & 5249 & 6,888 & & 3104 & 5962 & 8,989 & & \\
\hline 40 & 1907 & 3662 & 5522 & 7,247 & & 3266 & 6272 & 9,457 & & \\
\hline 41 & 2013 & 3832 & 5807 & 7,627 & & 3447 & 6563 & 9,944 & & \\
\hline 42 & 2112 & 4022 & 6094 & 8,003 & & 3617 & 6887 & 10,435 & & \\
\hline 43 & 2213 & 4215 & 6387 & 8,389 & & 3791 & 7219 & 10,938 & & \\
\hline 44 & 2318 & 4413 & 6687 & 8,783 & & 3970 & 7558 & & & \\
\hline 45 & 2424 & 4617 & 6995 & 9,188 & & 4152 & 7906 & & & \\
\hline 46 & 2533 & 4824 & 7309 & 9,600 & & 4339 & 8261 & & & \\
\hline 47 & 2645 & 5036 & 7631 & 10.022 & & 4530 & 8624 & & & \\
\hline 48 & 2759 & 5253 & 7959 & & & 4725 & 8995 & & & \\
\hline 49 & 2875 & 5474 & 8294 & & & 4923 & 9374 & & & \\
\hline 50 & 2993 & 5700 & 8636 & & & 5126 & 9761 & & & \\
\hline
\end{tabular}

* Vertical mode - force, lb; torsionel mode - torque, ft-lb.

** Eccentricity of the unbalanced mass is 4.0 inches.

Note: Maximum operating force level 10,000 pound.

Recommend 5,000 pound for continuous operation. 
surface measurements made on a line away from the vibrator at constant vibratory forces and various frequencies. Group A was divided into two series with the vibrator operated in the vertical and torsional modes for series I and II, respectively. Group B consisted of series III through VIII with vertical and torsional tests conducted for each series. The transducers were positioned at different locations and elevations so that complete coverage of the borehole profile could be obtained for frequencies ranging from 10 to $50 \mathrm{~Hz}$. The vibrator was operated at various locations. Group C was similar to the series of tests conducted for group A except that the transducers were equally spaced in one borehole instead of on the surface. The vibrator was operated over a wide range of frequencies and forces. The tabulation below shows the plan of tests.

\begin{tabular}{|c|c|c|c|}
\hline Group & Description of Tests & $\begin{array}{l}\text { Series } \\
\text { No. }\end{array}$ & Mode of Vibration \\
\hline A & Surface measurements & $\begin{array}{l}\text { I } \\
\text { II }\end{array}$ & $\begin{array}{l}\text { Vertical } \\
\text { Torsional }\end{array}$ \\
\hline B & $\begin{array}{l}\text { Subsurface measurements with } \\
\text { transducers at various depths: } \\
\text { Major transducers on surface } \\
\text { and at 15-ft depth }\end{array}$ & III & Vertical and Torsional \\
\hline & $\begin{array}{l}\text { Major transducers at } 15-\mathrm{ft} \\
\text { depth }\end{array}$ & IV & Vertical and Torsional \\
\hline & $\begin{array}{l}\text { Major transducers at } 12-\mathrm{ft} \\
\text { depth }\end{array}$ & V & Vertical and Torsional \\
\hline & $\begin{array}{l}\text { Major transducers at } 9-f t \\
\text { depth }\end{array}$ & VI & Vertical and Torsional \\
\hline & $\begin{array}{l}\text { Major transducers at 6-ft } \\
\text { depth }\end{array}$ & VII & Vertical and Torsional \\
\hline & $\begin{array}{l}\text { Major transducers at } 3-f t \\
\text { depth }\end{array}$ & VIII & Vertical and Torsional \\
\hline
\end{tabular}




\begin{tabular}{|c|c|c|c|}
\hline Group & Description of Tests & $\begin{array}{l}\text { Series } \\
\text { No. } \\
\end{array}$ & Mode of Vibration \\
\hline C & $\begin{array}{l}\text { Subsurface measurements with } \\
\text { major transducers at various } \\
\text { depths in hole } 1 \text {. Vibrator } \\
10 \mathrm{ft} \text { from hole } 1 \text {. }\end{array}$ & IX & Vertical and Torsional \\
\hline
\end{tabular}

3.2.2 Instrumentation. A thirty-six channel, direct-readout oscillograph recorder was used to record the signal from the velocity-type transducers used during the tests. The signals were amplified with DC amplifers and terminated at the recorder. After the vibrator frequency and force level were set for each test, the recorder was turned on for approximately 5 to 10 seconds. A typical oscillogram of the resulting measured motion is shown in figure 4.

Selection of the transducer to be used to measure the displacements, velocities, frequencies, and phase relationships was given careful consideration. Moving-coil velocity-type pickups were chosen for sensitivity, uniform phase relationships, and frequency response. A total of 19 transducers, each with a natural frequency of $2.5 \mathrm{~Hz}$ and a sensitivity of $96.3 \mathrm{millivolt} / \mathrm{ips}$, were used throughout the test program.

One vertical transducer was located about 6 in. from the base of the vibrator during the entire test program. Six groups of transducers were each positioned on aluminum mounts (figure 5) to monitor movements in the vertical, radial, and transverse directions as related to the vibrator. Each triaxial array was sealed in a watertight 

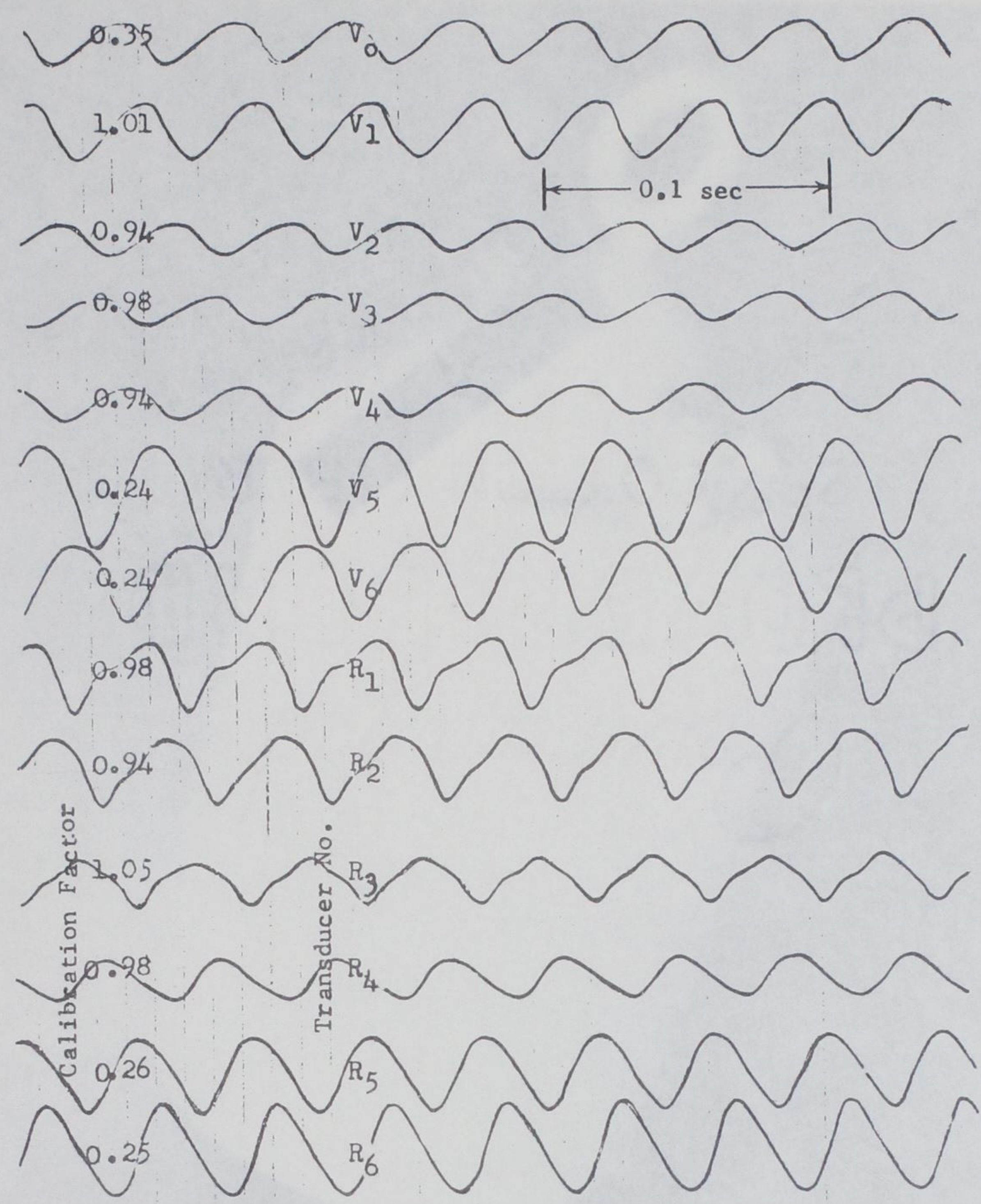

, 01 (n)
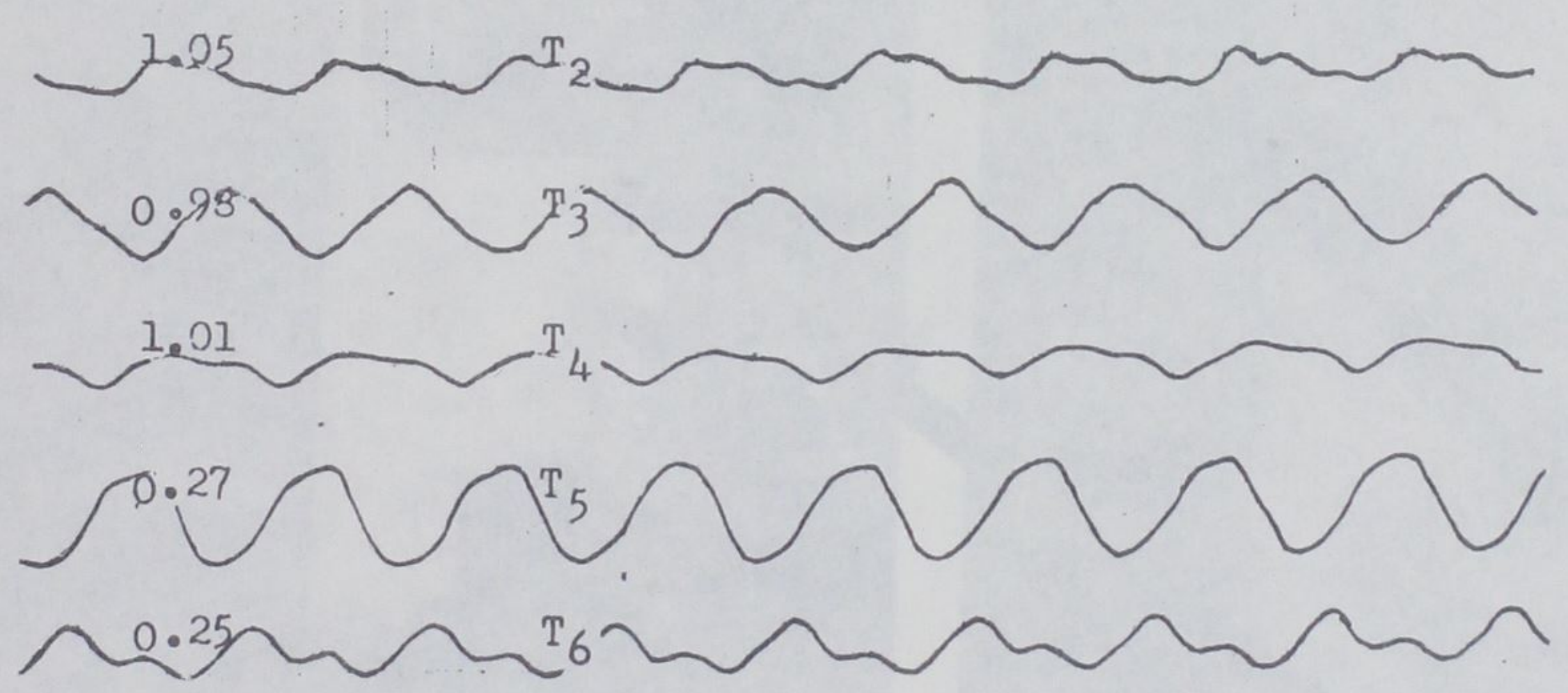

Peak Particle Velocity

$$
\begin{aligned}
\text { Vel }=\frac{(\mathrm{C})(\mathrm{m})}{2} \cdot \quad \mathrm{C}= & \text { Calibration, inches per sec/inch } \\
\mathrm{m}= & \text { Peak-to-Peak amplitude measured } \\
& \text { from record. }
\end{aligned}
$$

Figure 4. Typical Oscillogram Record Test $5,25 \mathrm{~Hz}$ 


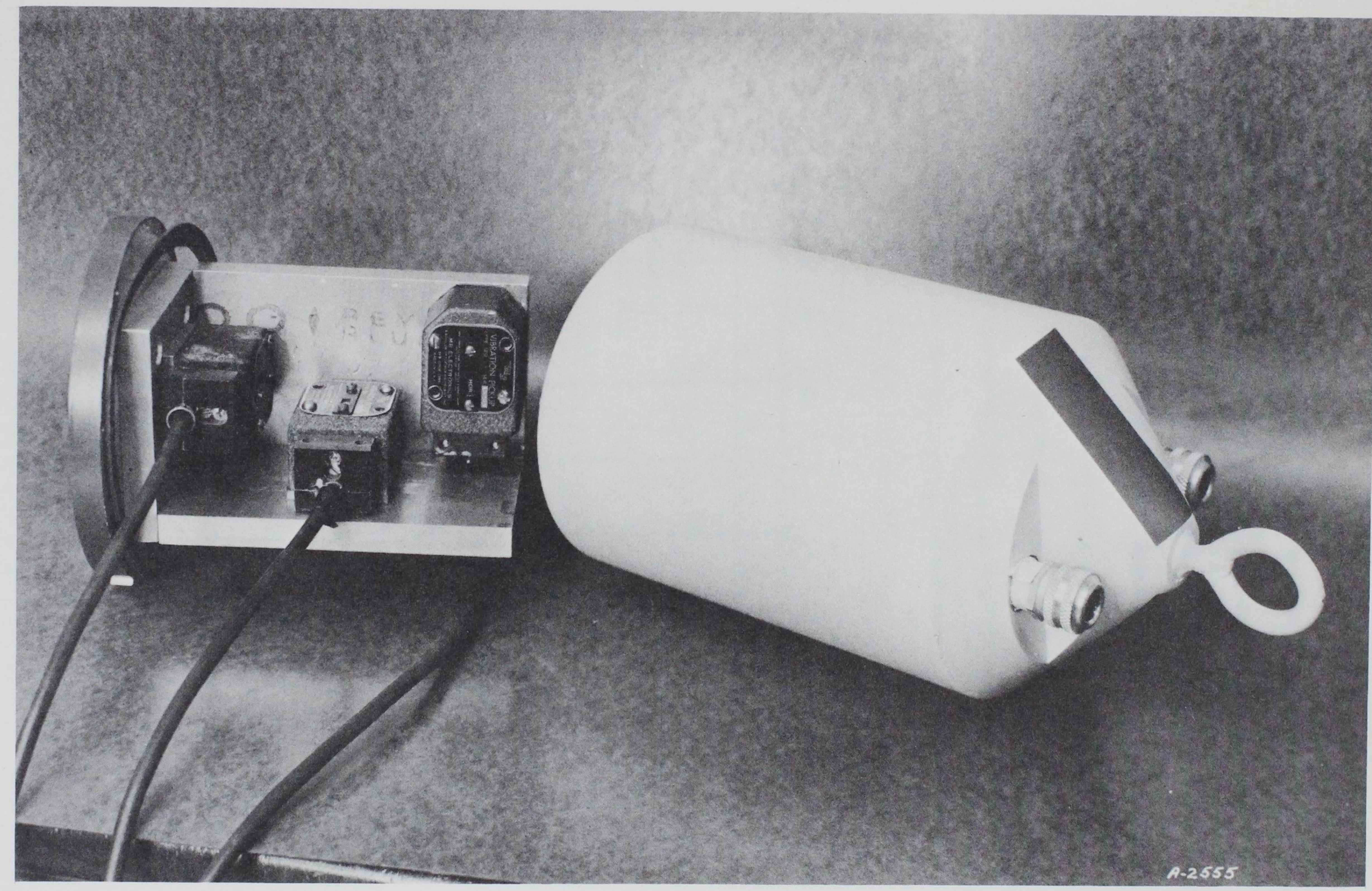

Figure 5. Velocity Transducers and Canister 
canister. Prior to each test, the canisters that housed the transducers were seated on clean, well-graded sand on the ground surface or in the boreholes. A compacted sand backfill was used to raise the canisters to different elevations in the boreholes. 


\section{TEST RESULTS}

\subsection{Surface Measurements - Group A}

4.1.1 Procedure and Operational Data. The first tests conducted were measurements on the ground surface. An attempt was made to maintain a constant force at various frequencies in the vertical and torsional modes. The data obtained during the torsion tests were not analyzed in this report. The vibrator was positioned 10 ft east of borehole 1 with the transducers positioned as shown in the diagram below:

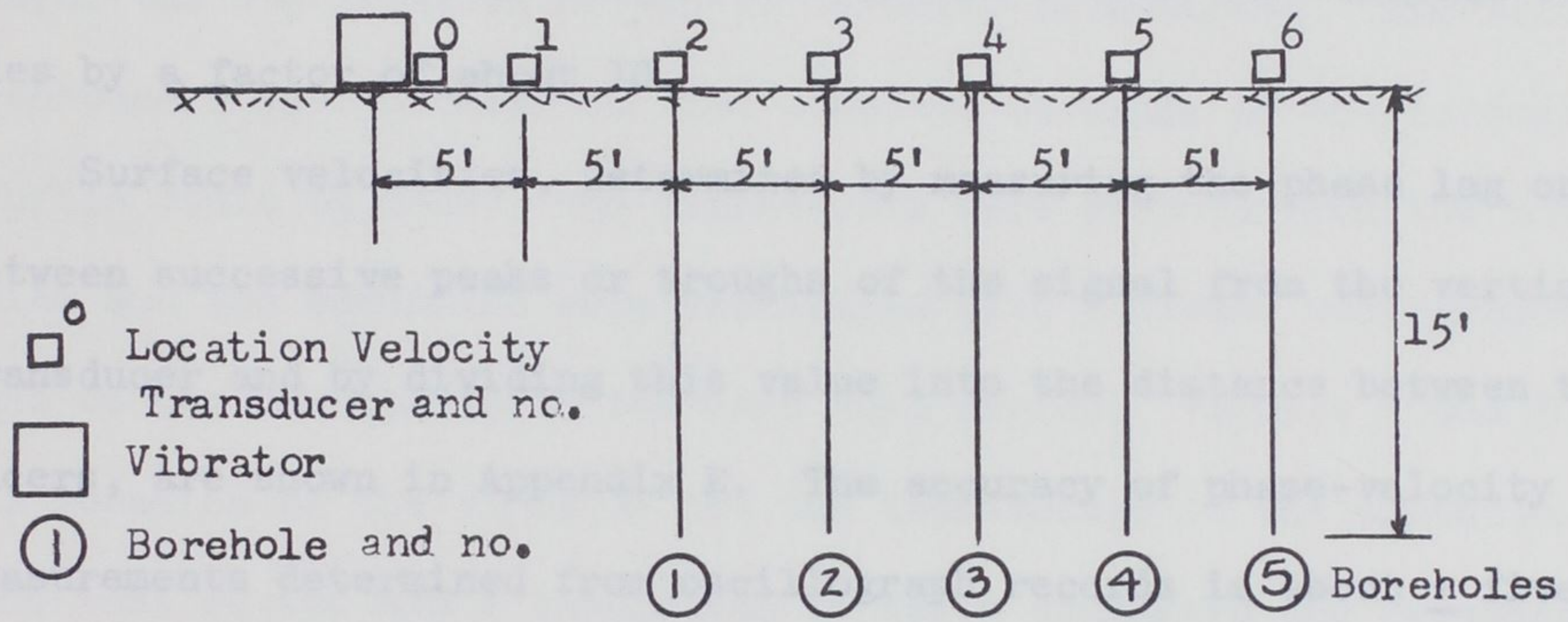

Figure 6. Group A test layout

The tests conducted were designated as series I and II for the vertical and torsional tests, respectively. Tabulated below are details of the tests.

Series I - Vertical Frequencies Force

Test No.

1

2

3

4

5

$\mathrm{Hz}$
$9-13$
$13-18$
$15-21$
$18-26$
$25-36$
-

1321-2758

$1310-2512$

1330-2608

1269-2651

$1276-2646$

\begin{tabular}{|c|c|c|}
\hline Test No. & $\begin{array}{l}\text { Frequencies } \\
\mathrm{Hz}\end{array}$ & $\begin{array}{r}\text { Torque } \\
\text { ft-lb }\end{array}$ \\
\hline 6 & $9 \cdot-13$ & 773 \\
\hline 7 & $13-18$ & $766-1468$ \\
\hline 8 & $15-21$ & $778-1525$ \\
\hline $9,9 a$ & $18-26$ & $742-1550$ \\
\hline 10 & $25-36$ & $745-1550$ \\
\hline
\end{tabular}


4.1.2 Measurements. The data recorded on the oscillograph were reduced by manual scaling techniques in terms of peak particle velocities and are tabulated in Appendix D, table D-1. Where no data are shown in the table, either the magnitude of the signal was not large enough to register or there was an instrumentation failure during the test. Maximum particle velocity on the surface was about 0.30 ips and occurred about $5 \mathrm{ft}$ from the vibrator operating in the vertical mode between 19 and $20 \mathrm{~Hz}$. Motion away from the vibrator generally increased to a point $5 \mathrm{ft}$ from the vibrator and then decreased. The measurements in the torsional mode were less than the vertical velocities by a factor of about 10 .

Surface velocities, determined by measuring the phase lag or time between successive peaks or troughs of the signal from the vertical transducer and by dividing this value into the distance between transducers, are shown in Appendix E. The accuracy of phase-velocity measurements determined from oscillograph records is about \pm five percent. Appendix E compares shear-wave velocities measured by the procedure outlined in Appendix $A$ and the phase-velocity measurements obtained from the oscillograph records recorded on the surface and at various depths. The phase velocities on the surface ranged from 380 to 500 fps for frequencies ranging from 10 to $36 \mathrm{~Hz}$. 


\subsection{Subsurface Measurements - Group B}

4.2.1 Procedure and Operational Data. The second group of tests consisted of subsurface measurements made with the vibrator located on the surface over borehole $I$ and $10 \mathrm{ft}$ and $20 \mathrm{ft}$ away from hole 1 . Vertical and torsional tests were conducted through a frequency range of 10 to $50 \mathrm{~Hz}$ with vibratory forces ranging from 392 to $9790 \mathrm{lb}$ in the vertical mode and torques ranging from 228 to $5720 \mathrm{ft}-\mathrm{lb}$ in the torsional mode. Test group B was divided into test series III - VIII with each series representing a different location of the vibrator and/or the six triaxial arrays of velocity transducers. The velocity transducers were located so that complete coverage of the borehole profile could be made. The transducers were removed from the boreholes and the boreholes were backfilled with a clean, well-graded sand to the new elevation for each test series. Figures 7 and 8 show the location of the vibrator and the transducers in the boreholes for each test series and a tabulation of tests conducted and frequency ranges .

4.2.2 Measurements. The particle-velocity measurements for group B were reduced from the oscillograph records in the same manner as those in group $A$ and are tabulated in Appendix D, table D-2. The magnitudes of the particle velocities during the vertical tests were greater near the surface and near the first borehole than at any other place in the borehole profile.

Phase-velocity measurements made between adjacent transducers are 


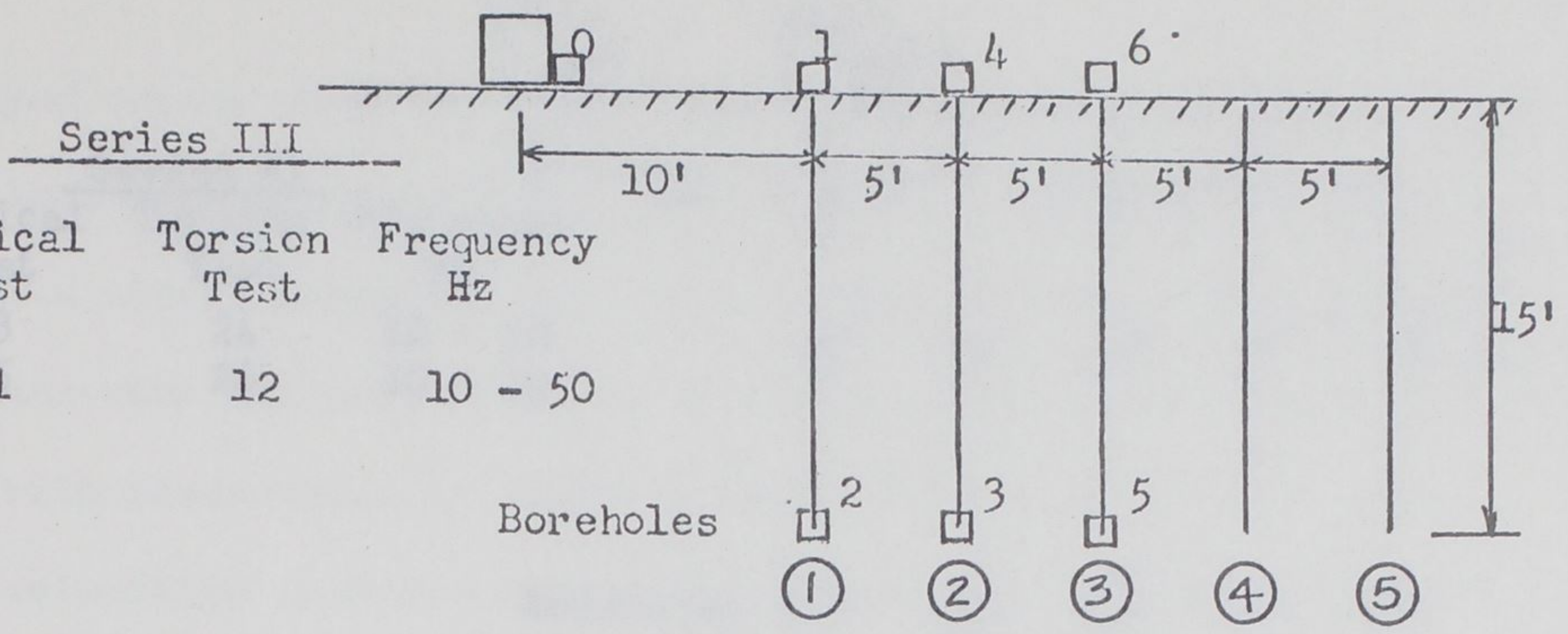

Vertical Torsion Frequency Test
11
12
$10-50$

Boreholes
(1)
(2)
(3)
(4)

(5)

Vertical Torsion Frequency

$$
\begin{array}{cc}
\text { Test } & \text { Test } \\
13 & 14 \\
15 & 16 \\
17 & 18
\end{array}
$$
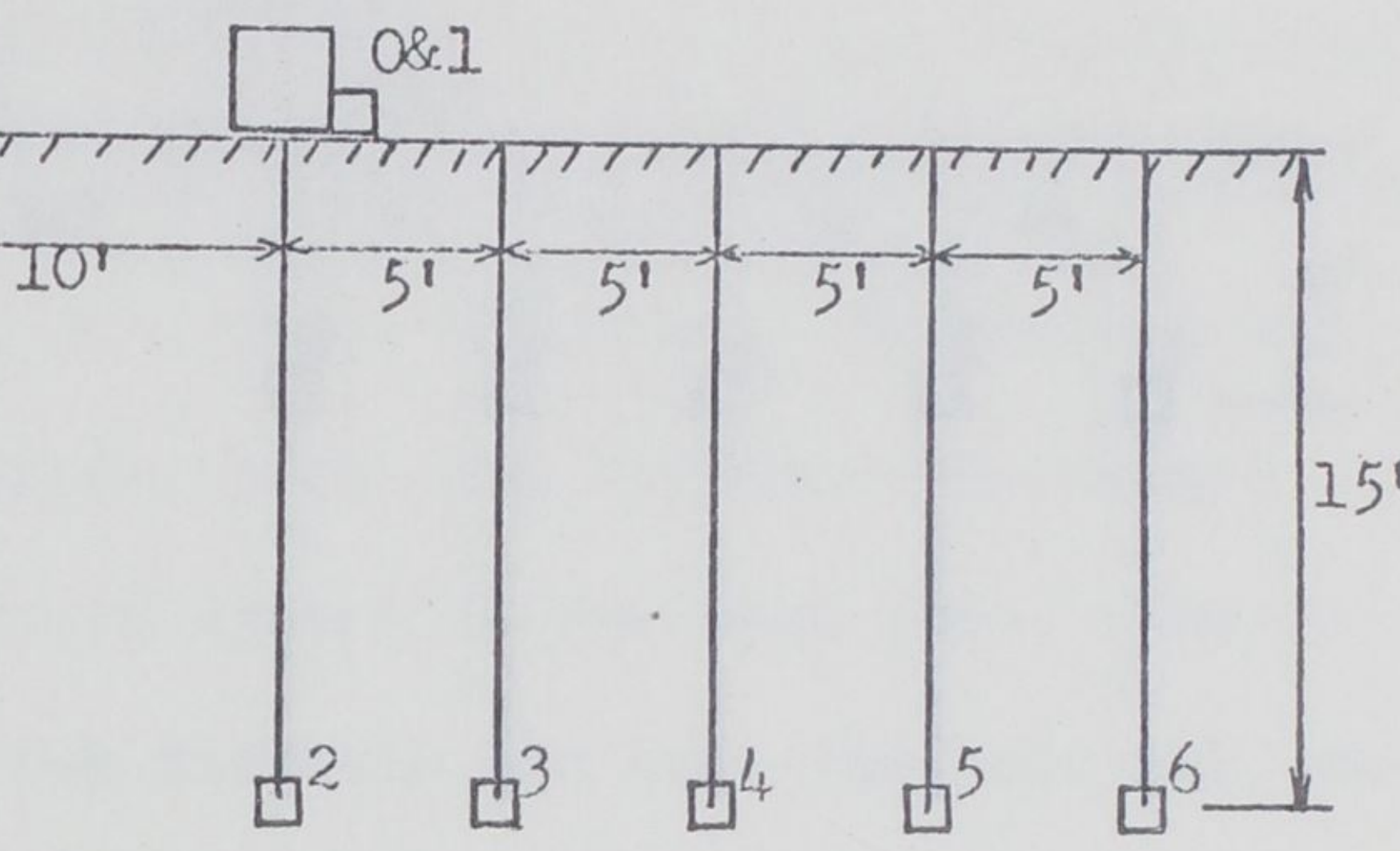

\section{Verties $V$}

Vertical Torsion Frequency

Test

19

21

20

22

$10-50$

$10-50$

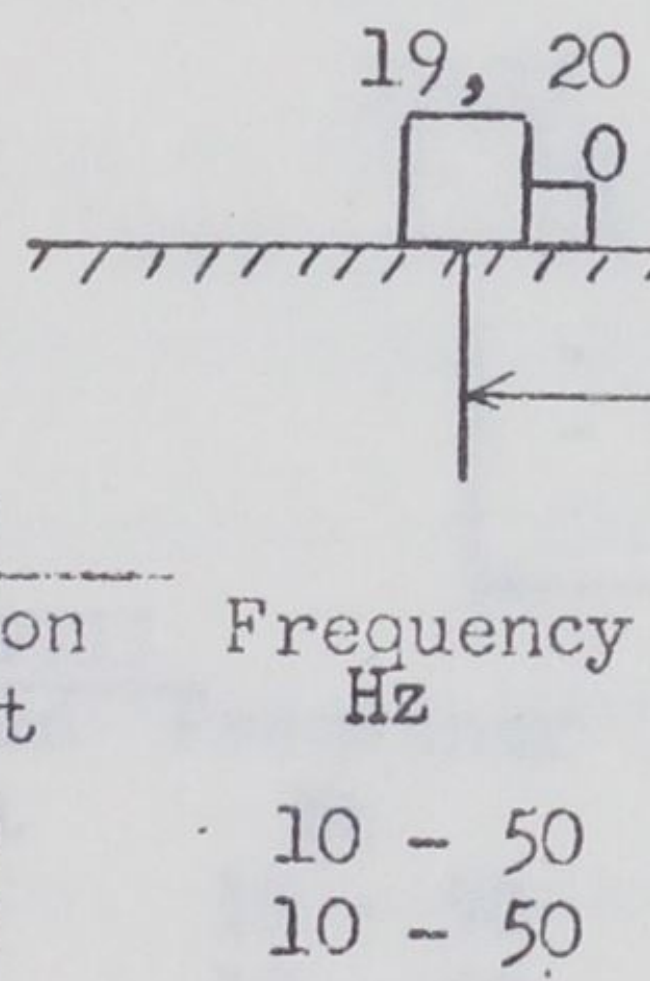

$\square^{0}$ Iocation Velocity Transducer and number

Vibrator

(1) Borehole and number
Figure 7 Test Group B Series III-V 


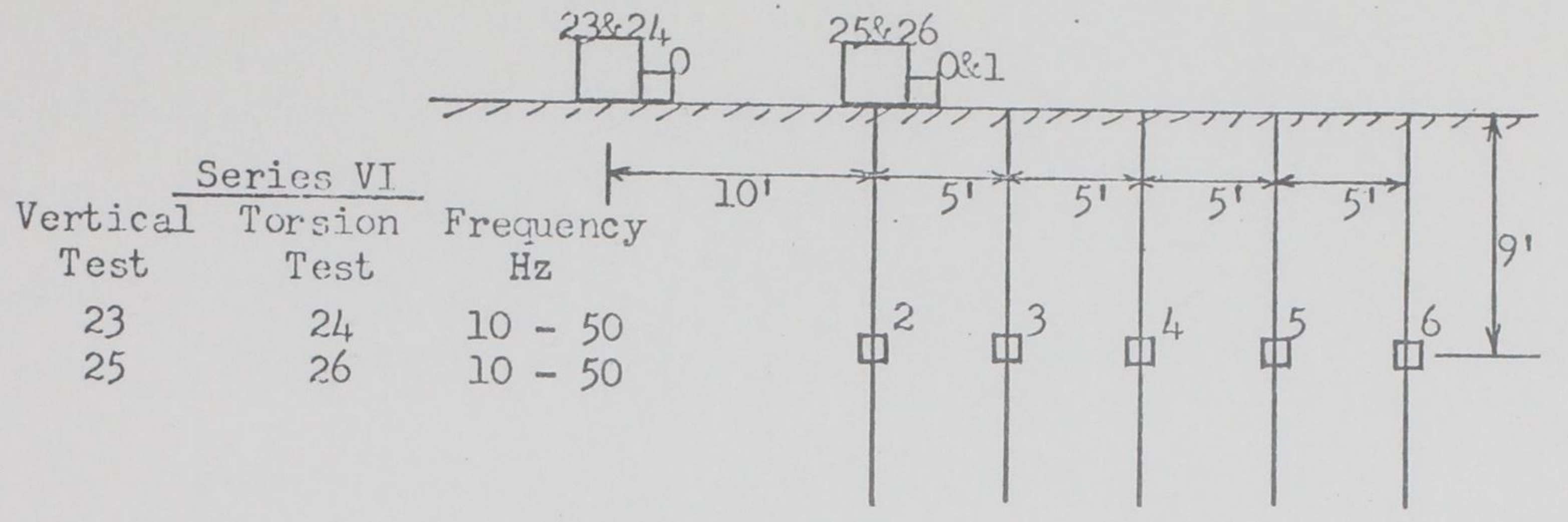

Boreholes (1) (2) (3) (4) (5)

Vertical Torsion Frequency

Test Test $\mathrm{Hz}$

$\begin{array}{lll}28 & 27 & 10-50 \\ 30 & 29 & 10-50\end{array}$

Vertical Series VIII

Test Test

Hiz

$32 \quad 31 \quad 10-50$

$34 \quad 33 \quad 10-50$

$\square^{0}$ Location Velocity Transducers and number

Vibrator

(1) Borchole and number

Figure 8. Test Group.B

Series VI-VIII 
displayed versus depth on a grid pattern of the boreholes and transducer locations in Appendix E. Each figure in Appendix E presents data at a single frequnecy and compares the one-half wavelength depths and shear-wave velocity computed by the procedure discussed in Appendix A with phase-velocity values listed in the grid pattern. The phase velocities from the grid system varied from 120 to 900 ips for frequencies ranging from 15 to $50 \mathrm{~Hz}$.

\subsection{Subsurface Measurements - Group C}

4.3.1 Procedure and Operational Data. Test group C was very similar to group A except that the transducers were located in one borehole at 3-ft intervals from the surface to a depth of $15 \mathrm{ft}$. Borehole 1 was backfilled with a clean, well-graded sand, and the sand was tamped with a rod and plate to the desired elevation for each test. The vibrator was located both $10 \mathrm{ft}$ from the hole and over the hole for test series IX and $X$, respectively, and operated in the vertical and torsional mode at each location. The vibrator frequency ranged from 9 to $50 \mathrm{~Hz}$, the force in the vertical mode varied from 776 to $9790 \mathrm{lb}$, and torque for the torsion tests varied from 453 to 5700 ft-lb. Figure 9 shows the location of the vibrator and transducer for each test series and a tabulation of tests conducted and frequency ranges. 4.3.2 Measurements. The subsurface particle velocity data acquired during the conduct of test series IX and $X$ are tabulated in Appendix D, table D-3. Recorded particle-velocity measurements for the vertical and torsional modes were in the same magnitude as those recorded 


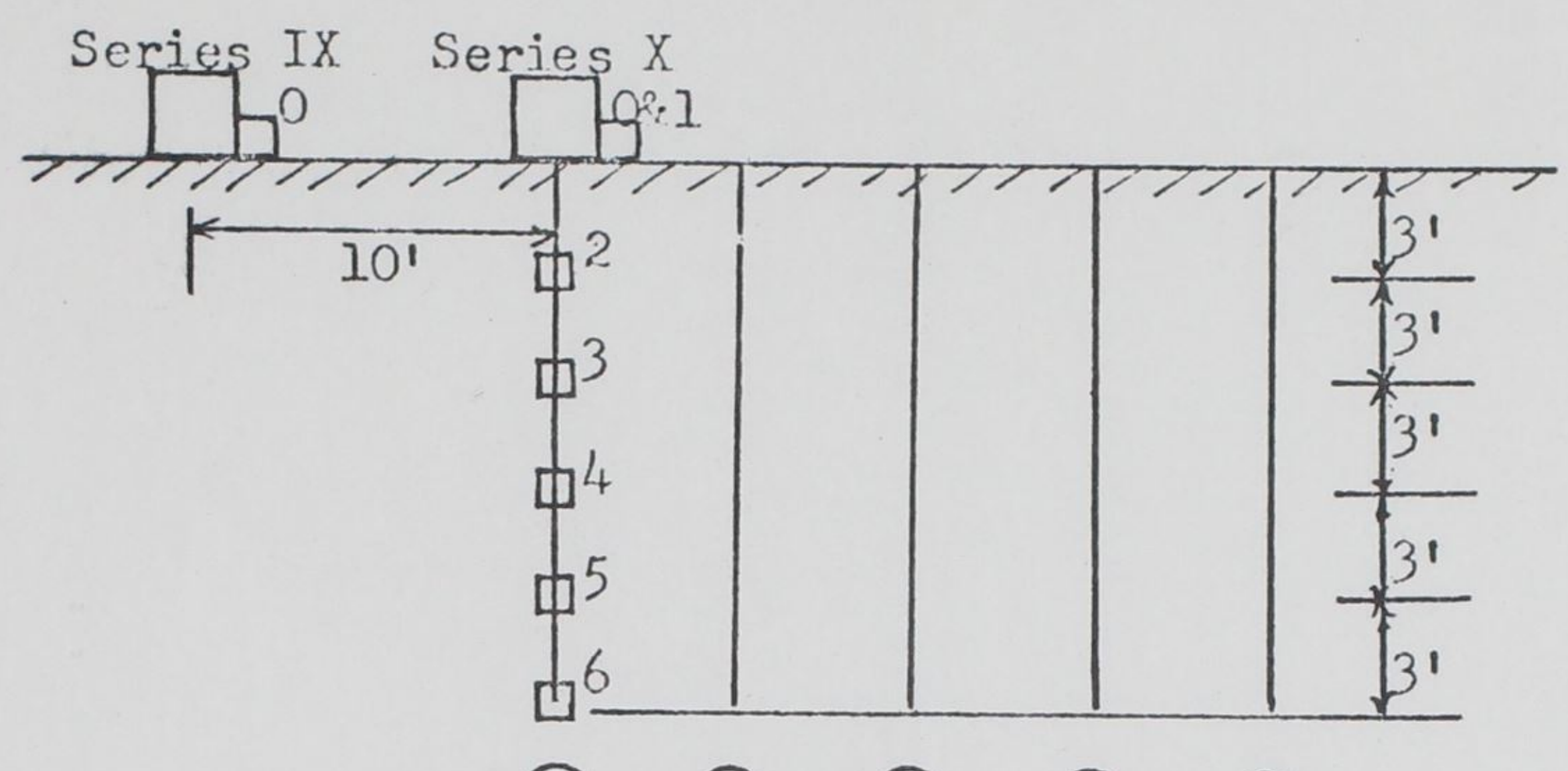

Boreholes (1) (2) (3) (4) (5)

\section{Serjes IX}

Vertical Test Frequency, $\mathrm{Hz}$ Torsion Test Frequency, $\mathrm{Hz}$

$\begin{array}{rr}35 & 10-50 \\ 36 & 12-114 \\ 37 & 9-12 \\ 38 & 15-21 \\ 39 & 18-26 \\ 49 & 25-36\end{array}$

41

42

43

44

45

46

$$
\begin{array}{r}
25-36 \\
18-26 \\
10-50 \\
13-18 \\
9-13 \\
15-21
\end{array}
$$

Series X

\begin{tabular}{cccc}
\hline Vertical Test & Frequency, Hz & Torsion “est & Frequency, \\
53 & $25-36$ & 47 & $15-21$ \\
54 & $18-26$ & 48 & $18-26$ \\
55 & $10-50$ & 49 & $10-50$ \\
56 A & $13-18$ & 50 & $13-18$ \\
57 & $15-21$ & 51 & $9-13$ \\
58 & $9-12$ & 52 & $25-36$
\end{tabular}
$\square^{0}$ Location Velocity Transducer
and number

Vibrator

(1) Borehole and number

Figure 9. Test Group C Series IX-X 
24.

during groups $\mathrm{A}$ and $\mathrm{B}$. The particle velocities in general decreased with depth. No phase-velocity measurements were made for this test group. 


\section{ANALYSIS OF RESULTS}

An analysis of the conventional soil tests and dynamic field and laboratory tests was made to determine relative homogeneity of the loess test section to a depth of $15 \mathrm{ft}$. An analysis was also made of the particle-velocity measurements, shear-wave velocities determined by the procedure outlined in Appendix A, and the phase velocities determined between adjacent vertical transducers located in the borehole profile. The analysis was made to determine the ralationship between the Rayleigh-wave velocity, particle velocity, and shear-wave velocity and the half-wave depth relationship of the shear-wave velocity.

\subsection{Conventional Soil Tests}

Conventional soils tests that included visual classifications, gradation analysis, Atterburg limits, densities, and water contents did not indicate any major differences or changes in the soil materials to a depth of $20 \mathrm{ft}$. Counts of the blows per ft taken during the split spoon sample tests indicated that the standard penetration resistance varied from 5 to 19 for a depth of about $20 \mathrm{ft}$. The visual classification and graduation indicated that the 15-ft-deep test section was a silty clay material (loess). The water content varied from about 23-33 percent; the wet density varied from about 110 to 120 pcf; the liquid limit varied from 28 to 36 , the plastic limit varied from about 23 to 26; and plasticity index varied from about 4 to 13 . The 
unconsolidated-undrained Q-test indicated shear strengths to be uniform with depth, varying from about 0.20 to 0.53 tons $/ \mathrm{sq}$ ft from the surface to a depth of $20 \mathrm{ft}$. Direct shear strengths were also uniform with depth varying from about 0.20 to 0.60 tons/sq ft. The unconfined compression strength ranged from 0.6 to 1.2 tons/sq ft. A comparison of the conventional static strength parameters is shown in a composite plot in figure 10; the parameters include standard penetration resistance, direct shear, and unconfined compressive strength versus depth. These data indicate that the soil materials are fairly homogeneous in strength from the surface to a depth of about $20 \mathrm{ft}$.

\subsection{Dynamic Laboratory and Field Moduli Tests}

Dynamic laboratory and field tests, conducted to determine the elastic and shear moduli of the soil, indicated that the field and laboratory test exhibited about the same values. The dynamic moduli determined in the laboratory and field test are shown versus depth in figure 10. The laboratory shear moduli varied from about 4200 to 8000 psi, and the field shear moduli varied from 5500 to 7200 psi from near the surface to a depth about $20 \mathrm{ft}$. The average compression (Young's) moduli were about three times the shear moduli. The close agreement of the laboratory and field measurements of the dynamic moduli is considered to be excellent. Both the dynamic moduli and the conventional soil measurements demonstrate that the test section soil is fairly homogeneous to a depth of about $20 \mathrm{ft}$. 

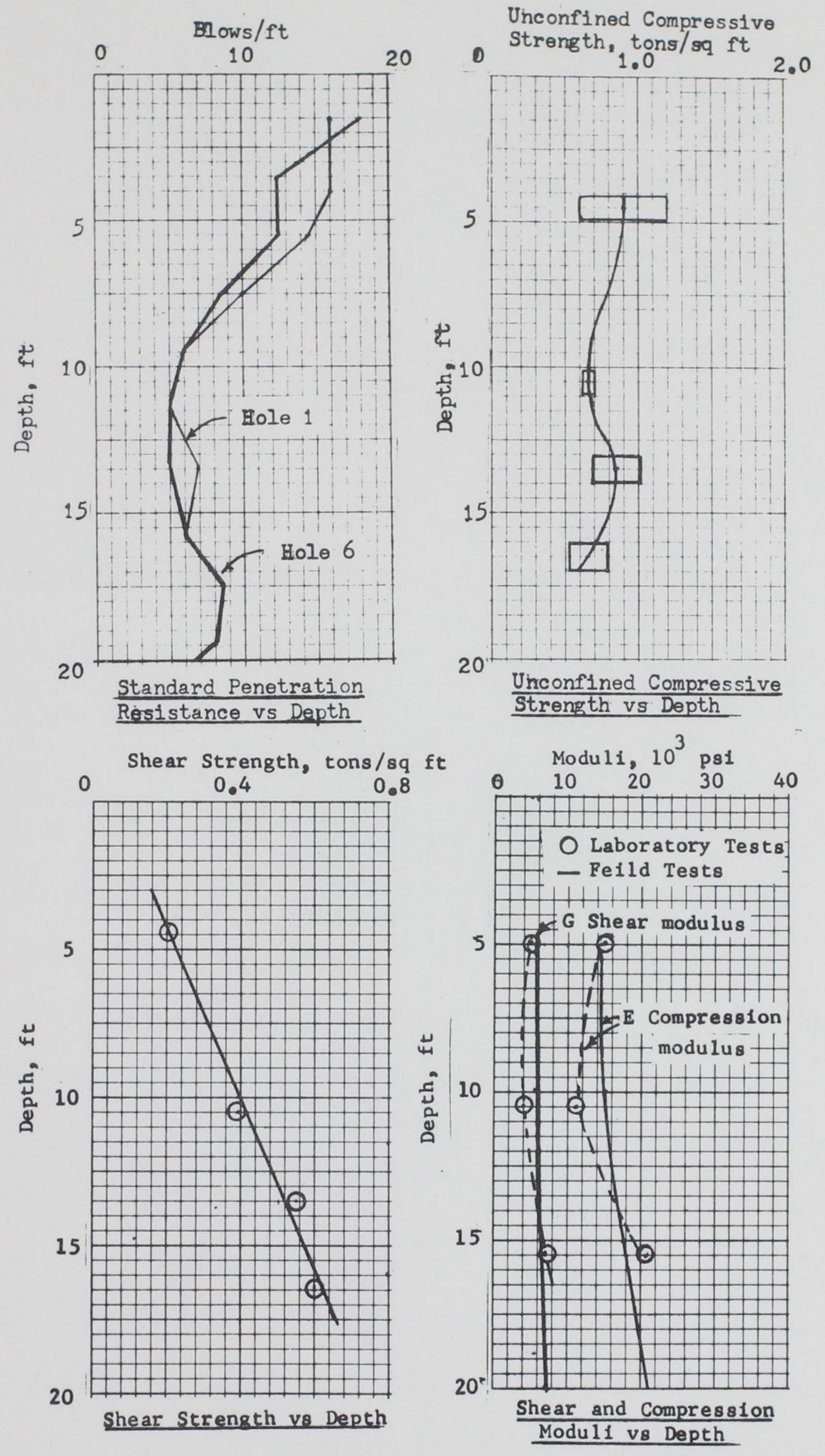

Figure 10. Comparsion of Strength Parameters 


\subsection{Phase-Velocity Measurements}

Comparisons were made of phase velocities from the dynamic laboratory tests, surface wave tests described in Appendix A, and from the velocity pickups buried at various depths in the test section. A comparison of the phase velocities determined from each method is shown plotted versus depth in figure 11. The laboratory and surface velocities were plotted at one half the wave length for individual frequencies from 15 to $50 \mathrm{~Hz}$. Subsurface phase velocities were determined at a depth of one half the wavelength (Appendix A) from the phase-velocity profiles shown in Appendix E. The phase velocities varied from about $450 \mathrm{fps}$ near the surface to about 530 fps at a depth of about $20 \mathrm{ft}$. The laboratory, surface, and subsurface phase velocities shown plotted in figure 11 indicate that each method exhibited about the same velocity for the depth of the test section. The phase-velocity data indicate that a fairly homogeneous material exists beneath the test section but does not necessarily confirm the concept that the surface wave propagates through a depth equal to one half the wavelength. The phase-velocity data (conventional and dynamic laboratory tests and field tests) confirm the homogeneity of the test section.

\subsection{Particle-Velocity Measurements}

The peak particle-velocity measurements versus distances for various depths below the ground surface for the vertical, radial, and transverse direction are plotted in Appendix F, figures F-l through F-8, for a range of frequencies from 15 to $50 \mathrm{~Hz}$. Each figure 


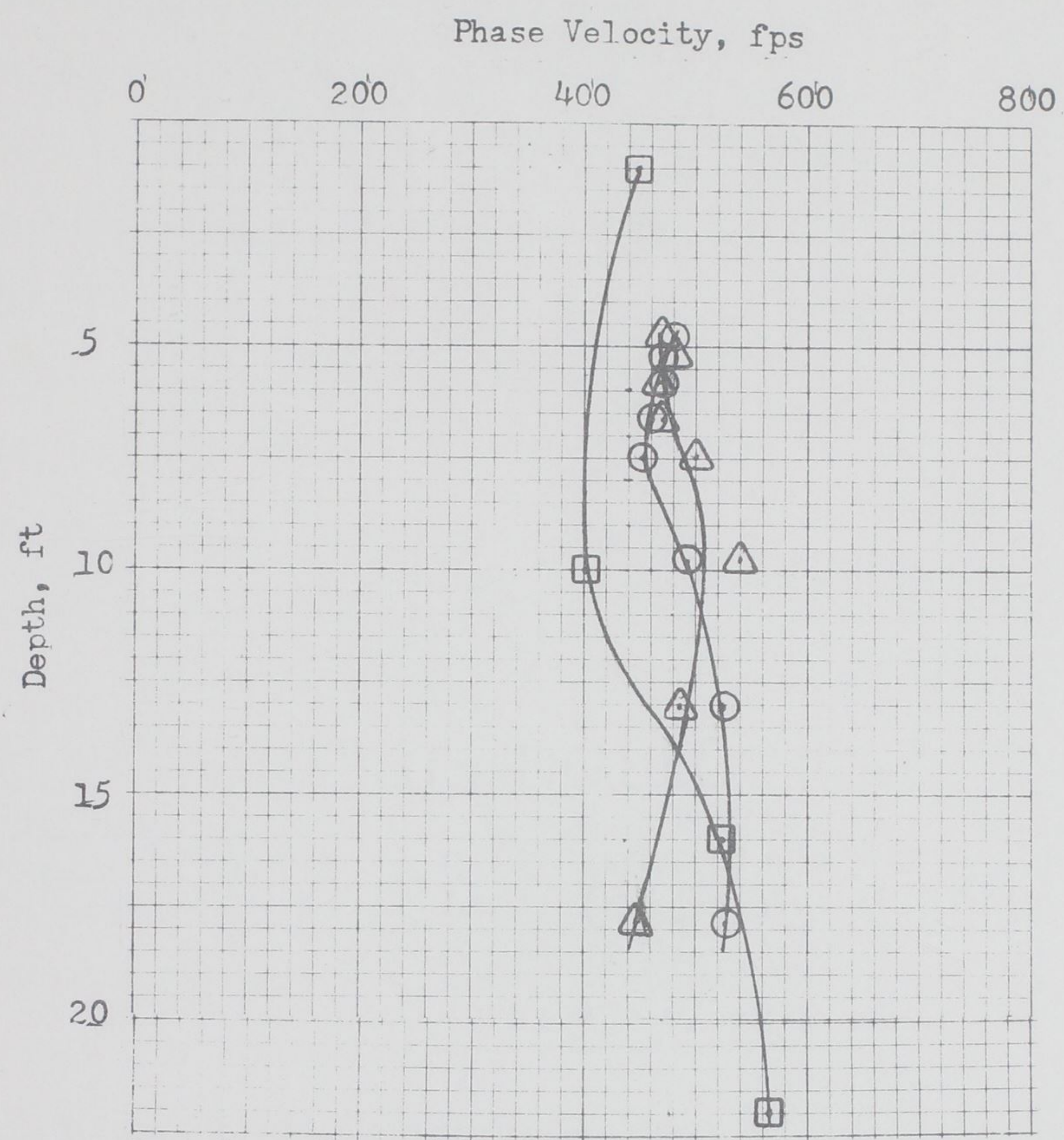

Symbol Phase Velocities

$\odot$ Velocity line $V-I$, surface

$\triangle$ Laboratory tests, subsurface

[.] Subsurface velocities determined at $\lambda / 2$ from the buried velocity transducers

Figure 11. Comparison of Phase Velocities 
presents data on particle velocities at a single frequency that was taken from test mun where the vibrator was located $10 \mathrm{ft}$ from hole $I$ and operated at about the same eccentric load. The peak particle velocities for the vertical, radial, and transverse directions with respect to vibrator location are plotted on the same vertical axis at each borehole location. The vertical particle velocities measured from the vibrator generally attenuated with distance; whereas, the radial and transverse measurement showed very little attenuation with distance.

Since figures F-l through F-8 only show particle velocity versus distance at given depths, a second series of plots were made that included particle velocity versus depth measured simultaneously in hole 1. Figures F-9 through F-ll include measurements made in the ver cal, radial, and trasverse directions, respectively, for a range of frequencies and eccentric loadings with the vibrator located $10 \mathrm{ft}$ from hole 1 and then located directly over the hole. The vertical particle velocity versus depth measured $10 \mathrm{ft}$ from the vibrator attenuated with depth for all frequencies except $50 \mathrm{~Hz}$. The particle velocity directly beneath the vibrator changed very little with depth at the lower frequencies but the values observed above 20 $\mathrm{Hz}$ showed an increase at a depth of about $3 \mathrm{ft}$ and then a decrease. The radial component plotted versus depth (Figure F-10) for the vibrator located $10 \mathrm{ft}$ from the hole showed very little change with depth. The radial particle velocity change directly beneath the vibrator attenuated to a depth of about $6 \mathrm{ft}$ and then remained constant 
to $15 \mathrm{ft}$. The transverse component plotted in figure F-ll for the vibrator located $10 \mathrm{ft}$ away from the hole indicated an increase in movement on the surface with an increase in frequency but remained fairly constant in amplitude from a depth of 3 to $15 \mathrm{ft}$. The transverse component measured directly beneath the vibrator decreased very little in magnitude from the surface to a depth of $15 \mathrm{ft}$.

The vertical and radial measurements discussed in the previous paragraphs are plotted in figures 12 and 13 as particle velocity ratio versus depth for the Rayleigh wave. The ratio of the particle velocity at some depth $\mathrm{z}$ to the surface particle velocity was plotted versus the depth-to-wavelength ratio for each frequency. The theoretical dispersion curves shown in figure 12 for different Poisson's ratios and points for the vertical components measured 10 ft from the vibrator are in very close agreement. This close agreement would suggest that the soil at the site of the investigation is a fair example of a homogeneous elastic half space. The radial components shown in figure 13 are also compared with the theoretical curves for different Poisson's ratio, except that these values were taken from measurements directly beneath the vibrator. The radial components $10 \mathrm{ft}$ from hole 1 were so scattered that only 10 percent of the values would plot on the graph. The field data for the radial components agree well with the theoretical curve. The dotted lines represent an envelope of the negative curves. The horizontal particle velocity depth-surface ratio and the depth-wavelength ratio fall into a narrow 


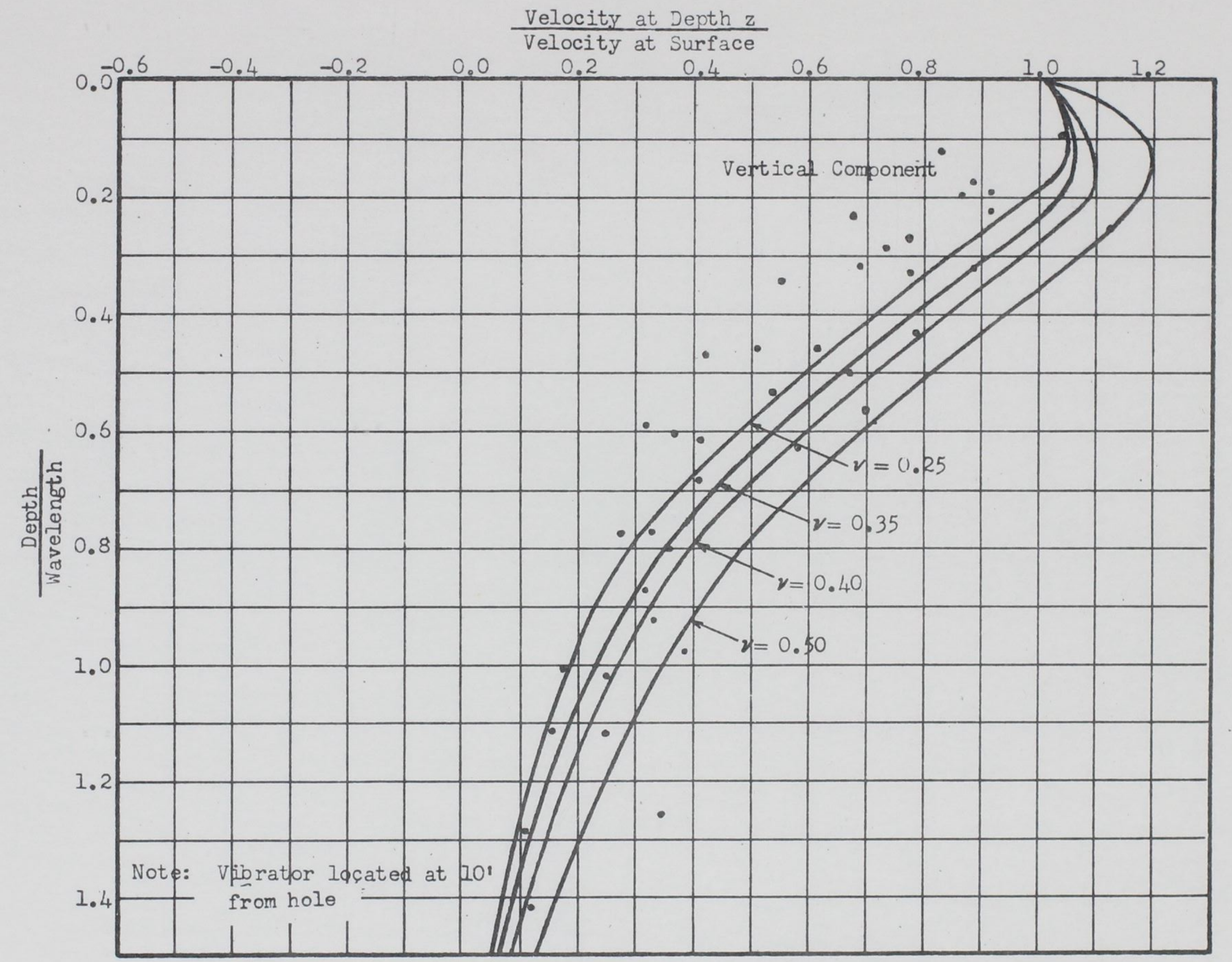

Figure 12. Vertical Particle Velocity Ratio versus Depth for Rayleigh Wave 


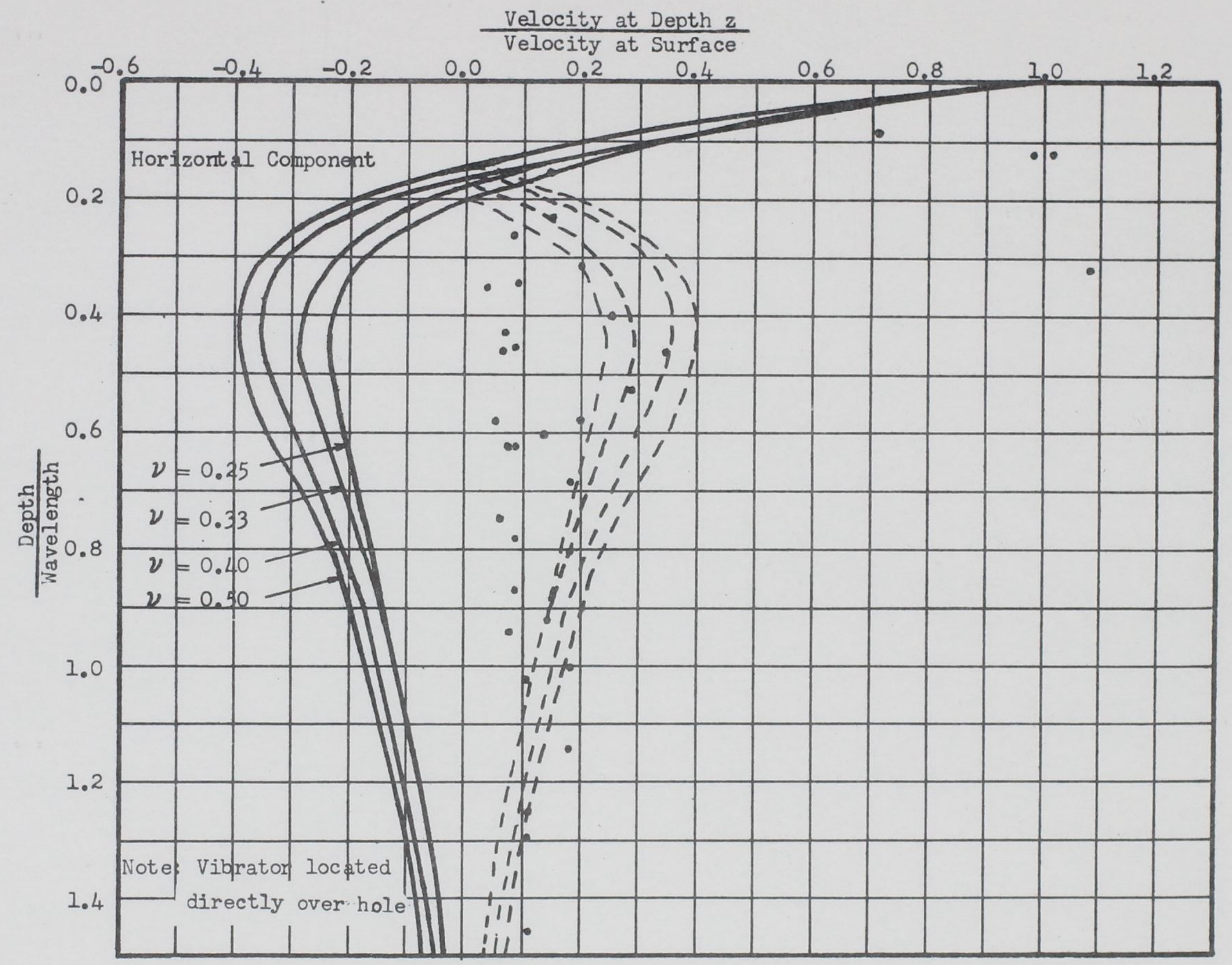

Figure 13. Radial Particle Velocity Ratio versus Depth for Rayleigh Wave 
pattern with very little scatter. The particle-velocity data do not suggest any physical relationship to exist to support the theory that surface waves penetrate the soil for a depth equal to one half the wavelength. The vertical particle velocity attenuated with an increase in depth from the vibrating source and there was relatively no change in the radial component with depth. 


\section{CHAPTER VI}

\section{CONCLUSIONS AND RECOMMENDATIONS}

\subsection{Conclusions}

It was concluded from the particle-velocity measurements that the soil at the site of the investigation represents a fairly homogeneous elastic half-space that causes very little dispersion of a vibrating wave in the medium. These data provide no explanation of or proof to support the theory that surface waves penetrate the soil for a depth equal to one half the wavelength. However, comparison of phase-velocity measurements reduced from the records from surface and subsurface transducers in the borehole profile and the shearwave velocities derived by the method outlined in Appendix A indicates excellent agreement of the methods of measurement.

It was further concluded from the analysis of the test results that the existing concept that the surface-wave propagates through a depth approximately equal to half the wavelength cannot be verified from tests of a homogeneous medium where there is practically no dispersion of the wave.

The shear-wave velocity varied from about 450 fps near the surface to about $530 \mathrm{fps}$ at a depth of about $20 \mathrm{ft}$. The conventional and dynamic laboratory and field tests of soil from the site indicated the soil represent a homogeneous elastic half-space. It is, therefore, concluded that the dynamic procedures outlined in Appendix A provide a reliable description of subsurface conditions at a site and accurate values of the in situ moduli of the medium and should be 
used in conjunction with conventional soils exploration and laboratory tests for the design of foundations subject to vibratory loads. 6.2 Recommendations

It is recommended that further studies of similar nature should be conducted and analysis of accumulated data be continued. Based on the agreement of the measurements and values obtained from the field test section, it is believed that additional studies are justified to further evaluate present criteria. Controlled test sections could be constructed or areas with various soil conditions could be selected that would include more dispersive materials or layered systems. The information thus obtained would be beneficial in evaluating present procedures for determining in situ soil characteristics. 


\section{ABSTRACT}

Jack Fowler, Master of Science, 1972

Department: Civil Engineering

Major: Soil Mechanics

Title of Thesis: An Evaluation of An Existing Procedure For Determining Shear Moduli at Depths by In Situ Vibratory Technique

Directed by Professor Robert M. Scholtes

Pages in Thesis, 123. Words in Abstract, 474.

\section{ABSTRACT}

The Corps of Engineers has been determining the dynamic characteristic of soil and pavement systems by the use of surface-induced vibrations for approximately 10 years. This non-destructive vibratory technique is utilized by all federal agencies involved in planning the design of space-craft launch and operation facilities, antiballistic missile sites, heavy weapons, air field and road construction, radar towers or structures to house delicate electronic equipment when accurate and quick information pertaining to the ability of the soils to resist deformation is required. The Corps of Engineers has been actively engaged in improving and developing equipment and procedures for determining the elastic moduli (and thus the resistance to deformation) of foundation soils by vibratory techniques. 
The basic theory assumes that the Rayleigh waves generated by the vertical oscillations of a vibrator on the soils surface are for all practical purposes considered to be shear-waves. When the waves are propagated at a known frequency, the wave velocity is determined by the product of the wave length and frequency. The shear-wave velocity propagation is assumed to take place within a depth equal to about one half the wavelength.

The purpose of this investigation was to validate the existing theory by determining shear moduli from the displacements, velocities, frequencies, phase relationship, and wave shape characteristics recorded versus distance and depth from a vibratory source placed on the ground surface. Specifically to evaluate the concept that the surface wave propagates through a depth about equal to one half the wavelength.

The results of this investigation indicated that the test section represented a fairly homogeneous elastic half-space which causes very little dispersion of a vibrating wave. Phase velocity measurements determined from surface and subsurface transducers were in excellent agreement. The conventional and dynamic laboratory and field tests of the soil from the site also indicated that the soil represented a homogeneous elastic half-space. The data collected offered no explanation or proof to support the theory that surface waves penetrate the soil for a depth equal to one half the wavelength. 
It was concluded from the analysis of the existing concept, that the surface wave propagates through a depth approximately equal to half the wavelength, cannot be verified from tests of a homogeneous medium where there is practically no dispersion of the wave. It was also concluded, however, that the vibratory technique does provide a reliable description of the subsurface condition and that the accurate values of in situ moduli of the medium should be used in conjunction with conventional soils exploration and laboratory tests for the design of foundations subjected to dynamic loads. It was recommended that similar tests be conducted on test sections that would include more dispersive soil materials or layered systems. Additional information from similar tests would be beneficial in verifying the present procedures for determing in situ soil characteristics. 
APPENDIX A

DETERMINATION OF ELAS TIC CHARACTERISTICS OF

SOILS BY DYNAMIC FIELD TECHNIQUES 


\section{APPENDIX A \\ DETERMINATION OF ELASTIC CHARACTERISTICS OF \\ SOILS BY DYNAMIC FIELD TECHNIQUES}

This appendix is a resume of the usual tests performed and methods employed in the investigation of in situ soils by dynamic techniques. While every test described herein may not be applicable to the study described in the main text, they are presented to describe better the methods and the basic theories on which the procedures are based.

\section{$\underline{\text { Seismic Tests }}$}

Seismic tests ${ }^{1,2}$ are made to determine the velocity of compression waves in the soil; this velocity value is used in conjunction with other data to determine Poisson's ratio. The seismic data are collected first so that the presence of unusual subsurface conditions, if any, can be revealed, and on the basis of this information, the vibration lines can be located to the best advantage. Data obtained with seismic equipment consist principally of the time required for a compression wave to travel from a seismic source to a point of measurement.

Data are plotted in graphic form as impulse distance versus travel time. The reciprocal of the slope of the line drawn to connect the plotted points indicates the velocity of the wave through each subsurface medium encountered. A distinct break in the slope of the 
line indicates that the wave has probably passed through an interface between two subsurface layers having different velocities. The depth below the surface at which the first interface occurs can be calculated from the following equation:

$$
D_{1}=\frac{x_{1}}{2} \sqrt{\frac{v_{2}-v_{1}}{v_{2}+v_{1}}}
$$

where

$D_{1}=$ depth, in feet, from the surface to the first interface, $L$

$x_{1}=$ distance, in feet, from seismic source to point at which first change in slope occurs, L

$v_{1}=$ compression-wave velocity, in feet per second, in first layer of material encountered, $\mathrm{LT}^{-1}$

$\mathrm{v}_{2}=$ compression-wave velocity, in feet per second, in second layer of material encountered, $\mathrm{LT}^{-1}$

If a second interface is encountered, the depth can be calculated from the following equation:

$$
D_{2}=\frac{5}{6} D_{1}+\frac{x_{2}}{2} \sqrt{\frac{v_{3}-v_{2}}{v_{3}+v_{2}}}
$$

where

$D_{2}=$ depth, in feet, from the surface to the second interface, $L$ $\mathrm{X}_{2}=$ distance, in feet, from seismic source to point at which second change in slope occurs, L

$\mathrm{v}_{3}=$ compression-wave velocity, in feet per second, in third layer of material encountered, $\mathrm{LT}^{-1}$ 
If additional interfaces occur, equations are available to determine their depth.

\section{Vibration Tests}

Vibration tests are conducted to determine both the frequency and the velocity of shear waves in the soil. The vibration tests are performed with a high-frequency electromagnetic vibrator and lowfrequency counterrotating-mass vibrator, in accordance with the procedure outlined in WES Miscellaneous Paper No. 4-577, A Procedure for Determining Elastic Moduli of Soils by Field Vibratory Techniques. The referenced report explains in detail how wavelengths of propagated Rayleigh waves (treated as shear waves) of known frequency are used to determine the shear and compression moduli of subsurface materials. Wave Propagation

When sustained vibrations are induced into a soil, concentric waves are propagated outward from the source. If the waves are propagated at a known frequency $f$, then $V=\lambda f$

where

$$
\begin{aligned}
& v=\text { wave velocity, } L T^{-1} \\
& \lambda=\text { wavelength }, L \\
& f=\text { frequency of the vibrator, cycles } T^{-1}
\end{aligned}
$$

Shear wave velocity and surface (Rayleigh) wave velocity are related by Poisson's ratio. For Poisson's ratios ranging from 0.2 to 0.5 , the difference in velocities is less than 6 percent. 
Therefore, for practical purposes, shear waves can be considered to have the same velocity as surface waves. Thus, shear velocities can be determined by the vibratory tests described.

Computation of elastic moduli and Poisson's ratios

Wave velocity is dependent upon the waveform and the ratio of the elasticity of the medium to its mass density $\rho$. The relation of shear modulus of elasticity $G$ and shear wave velocity $v_{S}$ is as follows :

$$
G=v_{S}^{2} \rho
$$

where

$$
\begin{aligned}
& \mathrm{G}=\text { shear modulus of soil, } \mathrm{FL}^{-2} \\
& \mathrm{v}_{\mathrm{S}}=\text { shear-wave velocity, } \mathrm{LT}^{-1} \\
& \rho=\text { mass density of soil, } \gamma / \mathrm{g}, \mathrm{FL}^{-4} \mathrm{~T}^{-2} \\
& \gamma=\text { wet unit weight of soil, } \mathrm{FL}^{-3} \\
& g=\text { acceleration of gravity, } \mathrm{LT}^{-2}
\end{aligned}
$$

With the assumption that compression-wave velocity and shearwave velocity were determined for comparable materials, Poisson's ratio can be calculated from the ratio of velocities $v_{r}$ :

$$
\mathrm{v}_{\mathrm{r}}=\frac{\mathrm{v}_{\mathrm{c}}}{\mathrm{v}_{\mathrm{s}}}
$$

Poisson's ratio $\nu$ is then

$$
v=\frac{v_{r}^{2}-2}{2\left(v_{r}^{2}-1\right)}
$$


The compression modulus E (Young's modulus) can be determined by :

$$
\mathrm{E}=2(1+\nu) \mathrm{G} \quad \text { (reference 5) }(\mathrm{A} 7)
$$

It should be noted here that equations A4 through A7 are for homogeneous, isotropic, elastic materials.

Method of Computation

The preceding paragraphs have discussed the theory and mathematics utilized in the seismic and vibratory techniques for obtaining Poisson's ratio and the elastic moduli of soils. To present and utilize properly the data collected, a definite pattern, or sequence of computation, has evolved as experience progressed.

The basic data obtained by means of the vibratory technique are plotted as distances from vibrator to successive half or whole wavelengths versus the number of wavelengths. The wavelength for a particular frequency is determined as the reciprocal of the slope of the line through the plotted data points. The velocity of the shear wave is then determined by equation A3. A compression-wave velocity, which is determined by use of equations $\mathrm{Al}$ and $\mathrm{A} 2$, is used together with the shear-wave velocity to determine a Poisson's ratio by equation A6. Caution should be exercised to ensure selection of the shear-wave and compression-wave velocities for corresponding media or depths. Based on experience of the WES, it appears that variations in $\mathrm{E}$ and $\mathrm{G}$ correlate best with conventional exploration methods when it is assumed that the depth for the computed 
value of $E$ and $G$ is one half the length of the surface wave. Therefore, the computed values of $\mathrm{E}$ and $\mathrm{G}$ are considered to be the elastic moduli at such a depth. Using one half the length of the surface wave as the depth at which the velocity of propagation of that wave occurs, and the velocity of the compression wave at a corresponding depth, a Poisson's ratio can be obtained for materials at different depths. The elastic moduli, $\mathrm{E}$ and $\mathrm{G}$, can then be computed by means of equations $A 7$ and $A 4$, respectively. It is usually convenient to plot $E$ and $G$ versus depth, which again is considered to be one half the wavelength of the surface wave. Such a plot provides a visual picture of the change in soil characteristics with increasing depth. The depth can also be expressed as overburden pressure in pounds per square inch, thus providing a comparison of $E$ and $G$ with increasing pressure. 
APPENDIX B

CONVENTIONAL SOILS TESTS 
APPENDIX B

CONVENTIONAL SOILS TESTS

Drilling, collection, and classification of soil samples for the field and laboratory soil tests were conducted by personnel of the WES Inspection Exploration Section and Soils Test Section. Collection of undisturbed soil samples, split spoon sampling and recording blows per ft, and soil classification were conducted during drilling operations. Conventional laboratory tests that were conducted on split spoon samples, included visual classification, gradation analysis, Atterburg limits, and water content determinations. Specific gravity tests and triaxial unconsolidated-undrained compressional (Q) tests were performed on undisturbed samples taken from Shelby tubes.

Data from the field and laboratory tests are shown in tables B-1 through $\mathrm{B}-3$. The soil at the site ranged from light to dark brown and gray silty clay (CL) to a depth of about $13.0 \mathrm{ft}$, with variation of soft and firm, brown and gray clayey silts (ML) from 13.0 to $125 \mathrm{ft}$ with a limestone layer at about 125 ft (determined during other investigations near the test area). Gradation curves for the subsurface materials at different depths are shown in figure B-l. The largest particle size was about $0.1 \mathrm{~mm}$ with 98 percent by weight finer than the No. 200 sieve size $(0.074 \mathrm{~mm})$. The standard penetration resistance blow count per ft for two holes, one 15 and one $22 \mathrm{ft}$ deep, are shown in figure B-2. A profile of the test area is shown in figure B-3, with the location of boreholes used for soil sampling and for instrumentation. 
The following ranges of soil properties were determined for the soil from the surface to a depth of about $22 \mathrm{ft}$.

$\begin{array}{lcl}\text { Specific gravity } & 2.68-2.71 \\ \text { Water content, } \% & 23.0-33.8 \\ \text { Dry unit weight, pcf } & 84-95 \\ \text { Void ratio } & 0.83-0.93 \\ \text { Liquid limit } & 28-36 \\ \text { Plastic limit } & 23-26 \\ \text { Plasticity index } & 41.1-100 \\ \text { Degree of saturation, } \% & 71.13\end{array}$

The plasiticity index versus liquid limit of samples from boring 1 are plotted on figure B-4.

Four specimens of undisturbed soil from average depths of 4.5 , 10.5, 13.5, and $16.5 \mathrm{ft}$, respectively, were used to determine the unconfined shear strength. The test specimens were nominally 1.4 in. in diam and $3.0 \mathrm{in.} \mathrm{long} \mathrm{and} \mathrm{were} \mathrm{tested} \mathrm{under} \mathrm{controlled-strain} \mathrm{con-}$ ditions. The results of these tests are shown in table B-l and figures B-5 through B-8. The unconfined compressive strengths were very uniform from $4 \mathrm{ft}$ to a depth of about $17 \mathrm{ft}$. The variation of compressive strength with depth is shown in figure B-9. The unconfined compressive strength ranged from about 0.6 to 1.2 tons/sq ft or 8.3 to $16.6 \mathrm{psi}$.

A total of six unconsolidated-undrained Q-tests were performed on undisturbed specimens from average depths of $4.5,7.8,10.5,13.5$, 
16.4, and $18.3 \mathrm{ft}$. Specimens were nominally $1.4 \mathrm{in}$. in diam and 3.0 in. high. The data from these tests are shown in table B-2 and figures $\mathrm{B}-10$ through $\mathrm{B}-15$. The cohesion $\mathrm{C}$ ranged from 0.2 to 0.5 tons/sq ft (2.8 to $6.9 \mathrm{psi}$ ) and the angle of friction $\varnothing$ decreased with depth, ranging from $12 \mathrm{deg}$ at the surface to 0 deg below a depth of about $13 \mathrm{ft}$. The shear strength varied with depth from 0.20 to 0.65 tons $/ \mathrm{sq}$ ft or 2.8 to $9.0 \mathrm{psi}$.

Direct shear tests were conducted on four undisturbed samples taken from average depths of $4.4,10.5,13.5$, and $16.4 \mathrm{ft}$. Initially, specimens were 3 in. square and 0.502 in. thick. The cohesion $\mathrm{C}$ ranged from 0.02 to 0.06 tons $/ \mathrm{sq}$ ft $(0.28$ to $0.82 \mathrm{psi})$ and the angle of friction $\varnothing$ ranged from 31 to $34 \mathrm{deg}$. The data from these tests are presented in table B-3 and in figure B-16 through B-19. Figure B-20 shows that shear strength increased as depth increased. 
Table B-I

Unconfined Compression Tests

\begin{tabular}{|c|c|c|c|c|c|c|c|c|c|}
\hline \multirow{2}{*}{$\begin{array}{c}\text { Depth } \\
\mathrm{ft} *\end{array}$} & \multirow[b]{2}{*}{ Material Description } & \multicolumn{2}{|c|}{$\begin{array}{c}\text { Unit Weight } \\
\text { pcf }\end{array}$} & \multirow{2}{*}{$\begin{array}{c}\text { Water } \\
\text { Content } \\
\% \\
\end{array}$} & \multirow{2}{*}{$\begin{array}{l}\text { Void } \\
\text { Ratio }\end{array}$} & \multirow{2}{*}{$\begin{array}{c}\text { Degree of } \\
\text { Saturation } \\
\%\end{array}$} & \multirow{2}{*}{$\begin{array}{l}\text { Specific } \\
\text { Gravity }\end{array}$} & \multirow{2}{*}{$\begin{array}{l}\text { Unconfined } \\
\text { Compressive } \\
\text { Strength } \\
\text { tons/sq ft }\end{array}$} & \multirow{2}{*}{$\begin{array}{c}\text { Undrained } \\
\text { Shear } \\
\text { Strength } \\
\text { tons/sq ft }\end{array}$} \\
\hline & & Wet & Dry & & & & & & \\
\hline $4.1-4.8$ & Silty clay (CL), brown & 112 & 91 & 24 & 0.86 & 74.0 & 2.68 & $0.60-1.19$ & $0.30-0.60$ \\
\hline $10.1-10.9$ & Silty clay (CL), brown & 116 & 87 & 33 & 0.93 & 96.0 & 2.68 & $0.64-0.70$ & $0.35-0.32$ \\
\hline $13.0-14.0$ & Clayey silt (ML), brown & 120 & 91 & 33 & 0.87 & 100.0 & 2.71 & $0.68-1.02$ & $0.34-0.51$ \\
\hline $16.0-16.9$ & Clayey silt (ML), brown & 121 & 93 & 31 & 0.84 & 99.0 & 2.71 & $0.52-0.78$ & $0.26-0.39$ \\
\hline
\end{tabular}

Forehole IU

Data from Figures B5-B8 


\section{Triaxial Q Tests}

\begin{tabular}{|c|c|c|c|c|c|c|c|c|c|c|}
\hline $\begin{array}{l}\text { Borehole } \\
\text { Location } \\
\end{array}$ & $\begin{array}{c}\text { Depth } \\
\mathrm{ft}\end{array}$ & $\begin{array}{c}\text { Material } \\
\text { Description } \\
\end{array}$ & $\begin{array}{l}\text { Approxi- } \\
\text { mate Dry } \\
\text { Unit } W t \\
\text { pcf } \\
\end{array}$ & $\begin{array}{c}\text { Approxi- } \\
\text { mate } \\
\text { Water } \\
\text { Content } \\
\% \\
\end{array}$ & $\begin{array}{c}\text { Angle of } \\
\text { Friction } \\
\emptyset, \text { deg } \\
\end{array}$ & $\begin{array}{l}\text { Cohesion, } \\
\text { C } \\
\text { tons/ } \\
\text { sq ft } \\
\end{array}$ & $\begin{array}{l}\text { Approximate } \\
\text { Avg Over- } \\
\text { burden } \\
\text { Pressure } \\
\text { tons/sq ft }\end{array}$ & $\begin{array}{l}\text { Chamber } \\
\text { Pressure } \\
\text { psi } \\
\end{array}$ & $\begin{array}{l}\text { Compressive } \\
\text { Strength } \\
\text { tons/sq ft } \\
\end{array}$ & $\begin{array}{c}\text { Shear } \\
\text { Strength } \\
\text { tons/sq ft } \\
\end{array}$ \\
\hline \multirow[t]{6}{*}{$1 \mathrm{U}$} & $4.1-4.8$ & $\begin{array}{l}\text { Silty clay } \\
(\mathrm{CL}) \text {, brown }\end{array}$ & 91 & 23 & 12 & 0.3 & 0.25 & $\begin{array}{r}3.5 \\
7.0 \\
21.0\end{array}$ & $\begin{array}{l}0.98 \\
1.00 \\
1.58\end{array}$ & $\begin{array}{l}0.53 \\
0.53 \\
0.65\end{array}$ \\
\hline & $7.5-8.0$ & $\begin{array}{l}\text { Silty clay } \\
(\mathrm{CL}) \text {, brown }\end{array}$ & 93 & 28 & 5 & 0.2 & 0.44 & $\begin{array}{r}6.2 \\
21.0\end{array}$ & $\begin{array}{l}0.43 \\
0.62\end{array}$ & $\begin{array}{l}0.20 \\
0.21\end{array}$ \\
\hline & $10.1-10.9$ & $\begin{array}{l}\text { Silty clay } \\
(\mathrm{CL}) \text {, brown }\end{array}$ & 86 & 32 & 3 & 0.3 & 0.60 & $\begin{array}{r}8.5 \\
21.0 \\
42.0\end{array}$ & $\begin{array}{l}0.65 \\
0.72 \\
0.88\end{array}$ & $\begin{array}{l}0.32 \\
0.33 \\
0.33\end{array}$ \\
\hline & $13.0-14.0$ & $\begin{array}{l}\text { Clayey silt } \\
(\mathrm{ML}) \text {, brown }\end{array}$ & 91 & 32 & 0 & 0.5 & 0.78 & $\begin{array}{l}10.8 \\
21.0 \\
42.0\end{array}$ & $\begin{array}{l}1.01 \\
0.94 \\
0.99\end{array}$ & $\begin{array}{l}0.49 \\
0.49 \\
0.49\end{array}$ \\
\hline & $16.0-16.9$ & $\begin{array}{l}\text { Clayey silt } \\
(\mathrm{ML}) \text {, brown }\end{array}$ & 93 & 31 & 0 & 0.4 & 0.96 & $\begin{array}{l}13.2 \\
21.0 \\
42.0\end{array}$ & $\begin{array}{l}0.60 \\
0.78 \\
1.12\end{array}$ & $\begin{array}{l}0.42 \\
0.42 \\
0.42\end{array}$ \\
\hline & $17.6-19.0$ & $\begin{array}{l}\text { Silt } \\
\text { (ML), grey }\end{array}$ & 95 & 29 & 0 & 0.5 & 1.14 & $\begin{array}{r}7.0 \\
15.0 \\
21.0\end{array}$ & $\begin{array}{l}0.86 \\
0.91 \\
1.03\end{array}$ & $\begin{array}{l}0.47 \\
0.47 \\
0.47\end{array}$ \\
\hline
\end{tabular}

Data obtained from Figures B]1-B15 
Table B-3

Direct Shear Tests

\begin{tabular}{|c|c|c|c|c|c|c|c|c|c|c|}
\hline $\begin{array}{l}\text { Borehole } \\
\text { Location } \\
\end{array}$ & $\begin{array}{c}\text { Depth } \\
\mathrm{ft}\end{array}$ & $\begin{array}{c}\text { Material } \\
\text { Description } \\
\end{array}$ & $\begin{array}{l}\text { Approxi- } \\
\text { mate Dry } \\
\text { Unit Wt } \\
\text { pcf } \\
\end{array}$ & $\begin{array}{c}\text { Approxi- } \\
\text { mate } \\
\text { Water } \\
\text { Content } \\
\% \\
\end{array}$ & $\begin{array}{c}\text { Angle of } \\
\text { Friction } \\
\emptyset, \text { deg } \\
\end{array}$ & $\begin{array}{l}\text { Cohesion } \\
\text { C } \\
\text { tons/ } \\
\text { sq ft } \\
\end{array}$ & $\begin{array}{l}\text { Approximate } \\
\text { Avg Over- } \\
\text { burden } \\
\text { Pressure } \\
\text { tons/sq ft }\end{array}$ & $\begin{array}{l}\text { Normal Stress } \\
\text { tons/sq ft } \\
\end{array}$ & $\begin{array}{l}\text { Shear Strength } \\
\text { tons } / \mathrm{sq} \mathrm{ft} \\
\end{array}$ & $\begin{array}{c}\text { Shear } \\
\text { Strength at } \\
\text { Overburden } \\
\text { Pressure } \\
\text { tons/sq ft } \\
\end{array}$ \\
\hline \multirow[t]{4}{*}{ IU } & $4.1-4.8$ & $\begin{array}{l}\text { S.ilty clay } \\
(\mathrm{CL}) \text {, brown }\end{array}$ & 88 & 23 & 31 & 0.06 & 0.25 & $\begin{array}{l}0.5 \\
1.5 \\
3.0\end{array}$ & $\begin{array}{l}0.38 \\
0.96 \\
1.86\end{array}$ & 0.20 \\
\hline & $10.1-10.9$ & $\begin{array}{l}\text { Silty clay } \\
(\mathrm{CL}) \text {, brown }\end{array}$ & 84 & 32 & 33 & 0.02 & 0.58 & $\begin{array}{l}0.5 \\
1.5 \\
3.0\end{array}$ & $\begin{array}{l}0.35 \\
0.96 \\
1.98\end{array}$ & 0.38 \\
\hline & $13.0-14.0$ & $\begin{array}{l}\text { Clayey silt } \\
(\mathrm{ML}), \text { brown }\end{array}$ & 87 & 31 & 34 & 0.03 & 0.75 & $\begin{array}{l}0.5 \\
1.5 \\
3.0\end{array}$ & $\begin{array}{l}0.37 \\
1.05 \\
2.05\end{array}$ & 0.55 \\
\hline & $16.0-16.9$ & $\begin{array}{l}\text { Clayey silt } \\
(\mathrm{ML}) \text {, brown }\end{array}$ & 90 & 30 & 32 & 0.02 & 0.93 & $\begin{array}{l}0.5 \\
1.5 \\
3.0\end{array}$ & $\begin{array}{l}0.34 \\
0.97 \\
1.88\end{array}$ & 0.60 \\
\hline
\end{tabular}




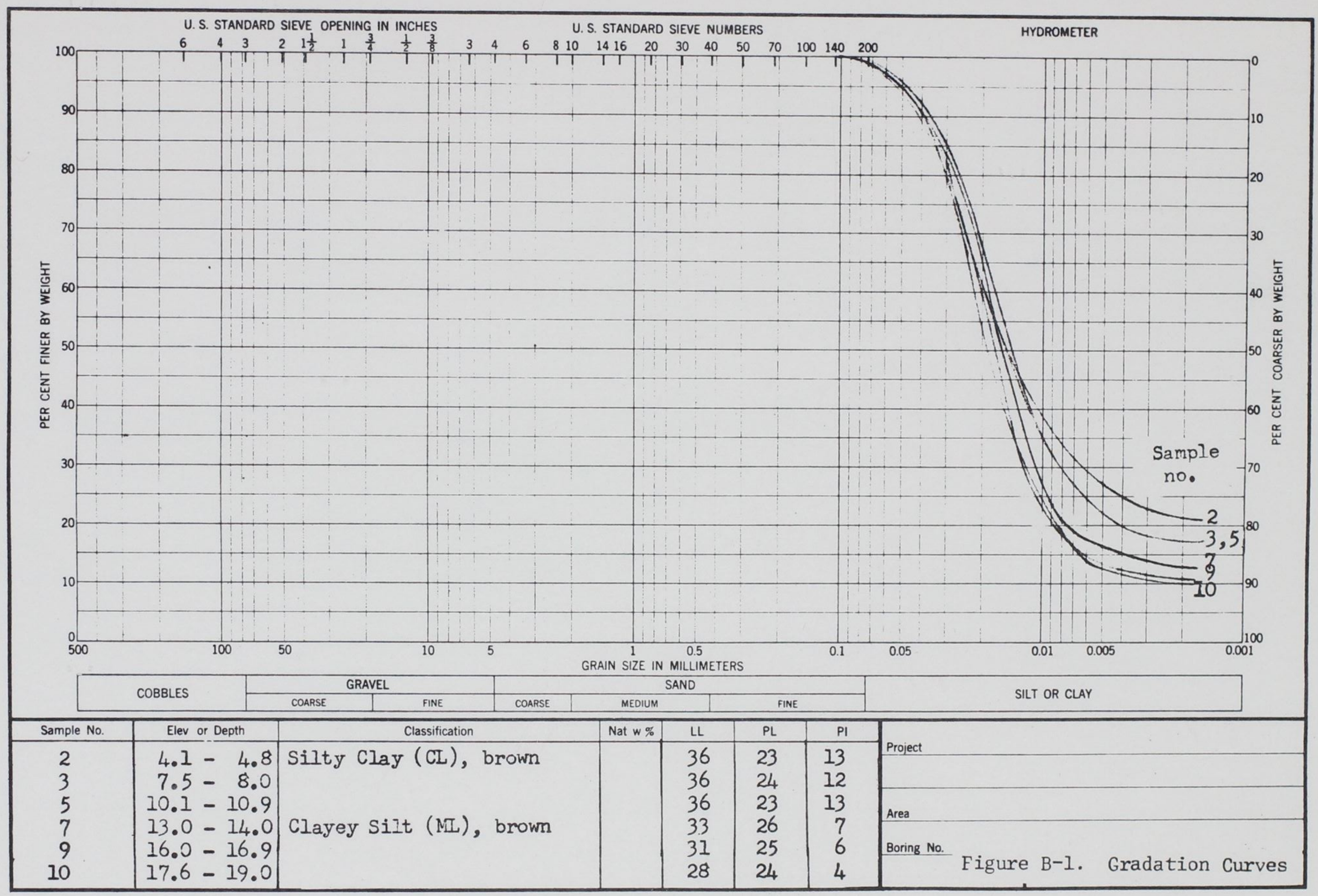




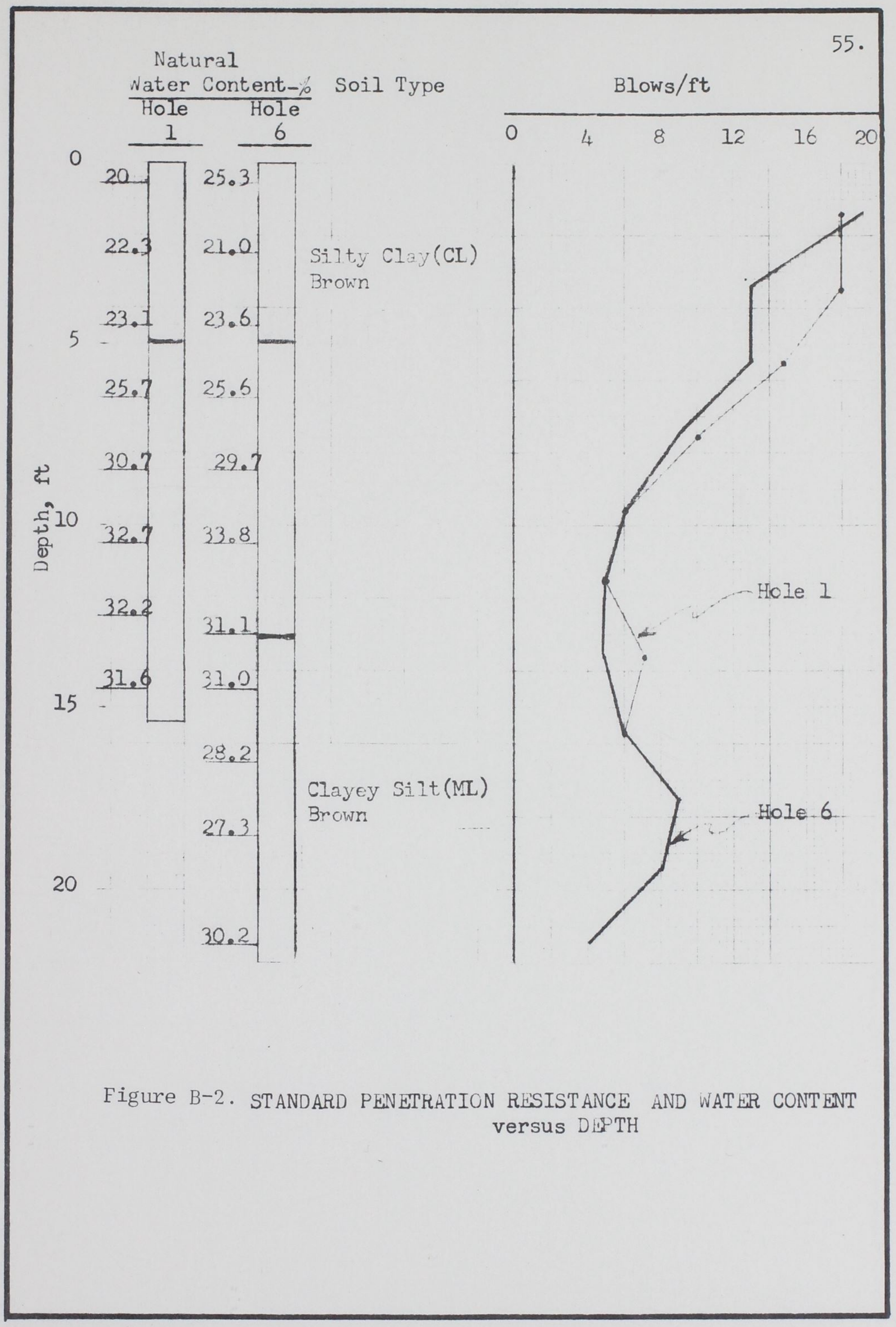




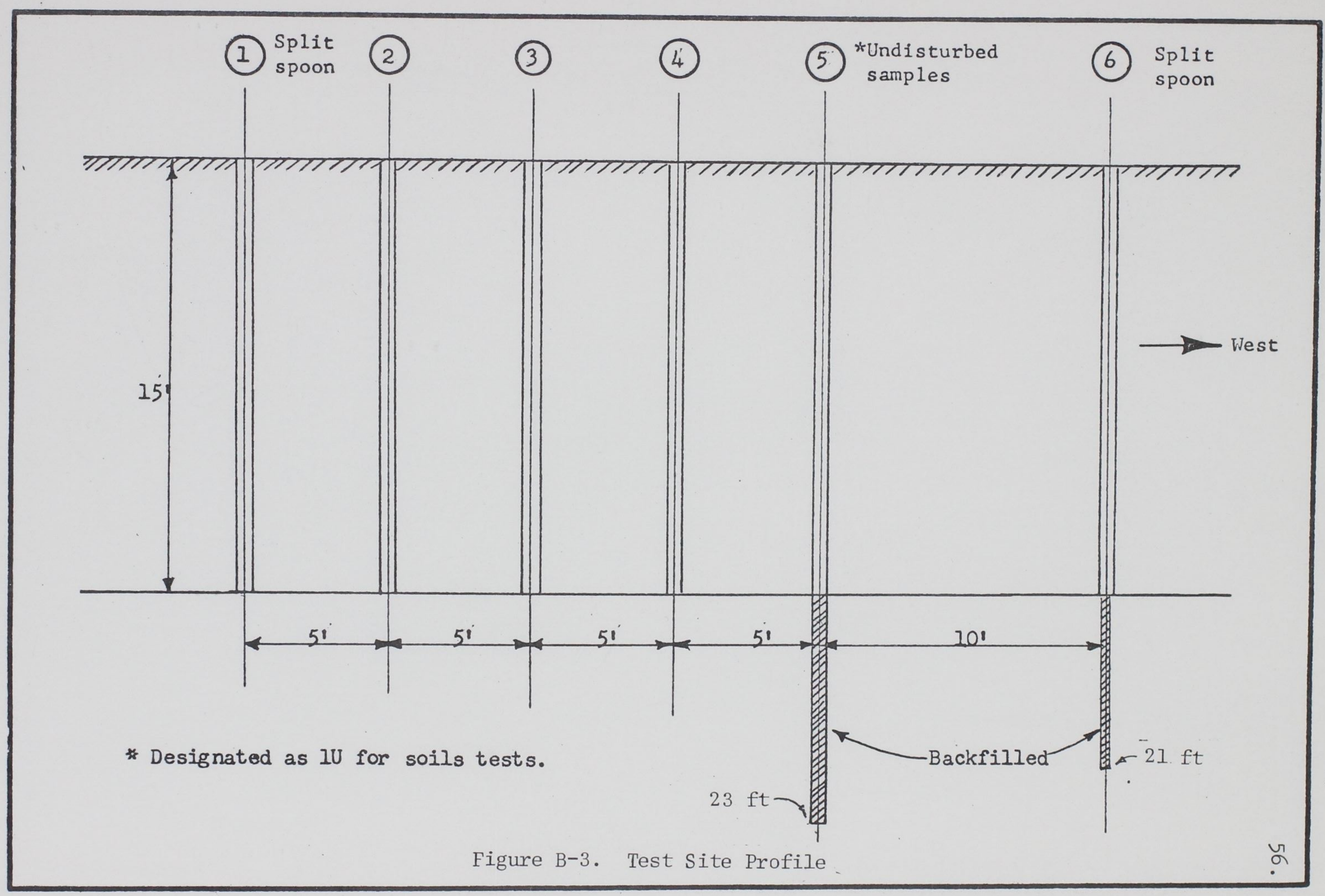




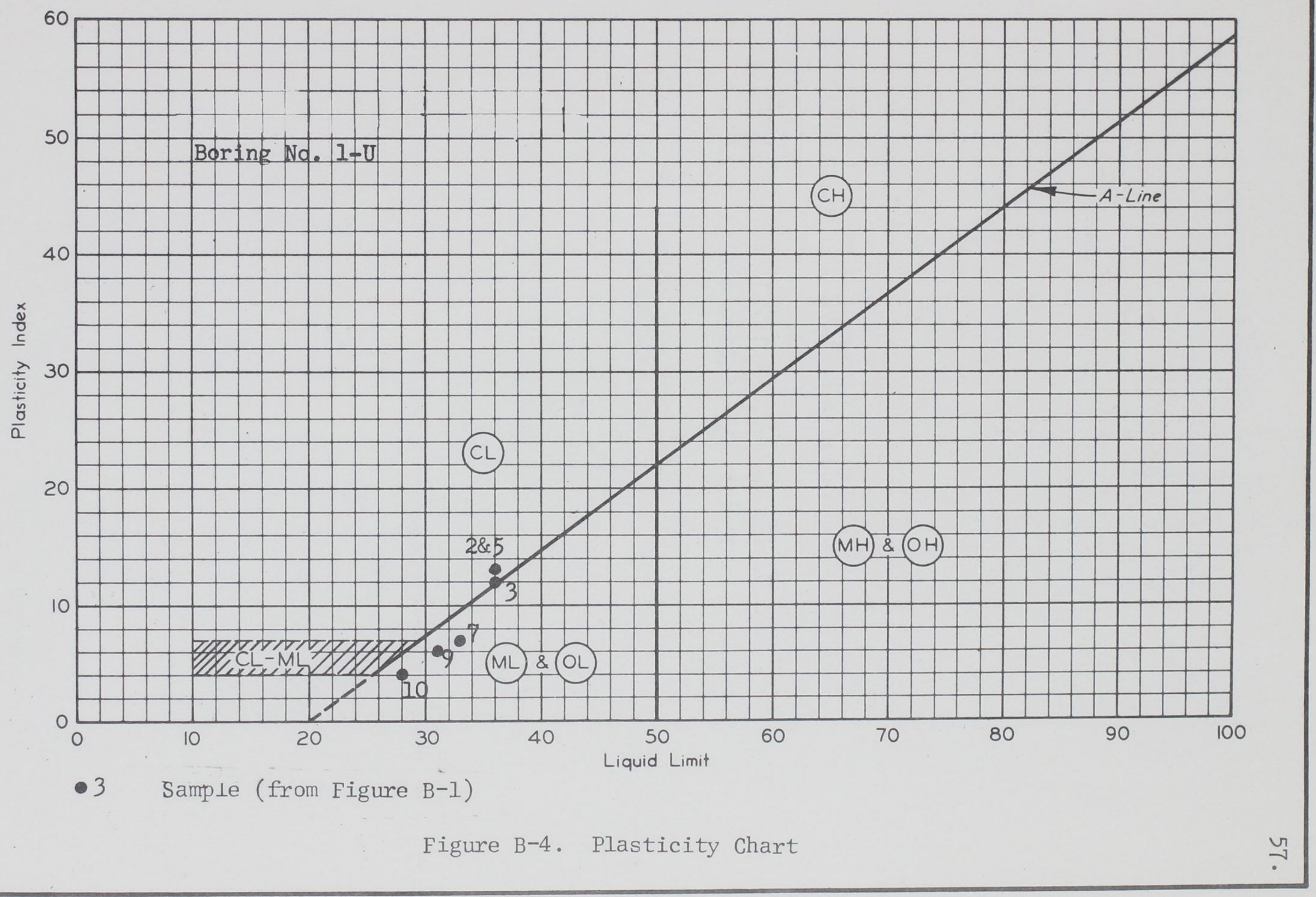


58.

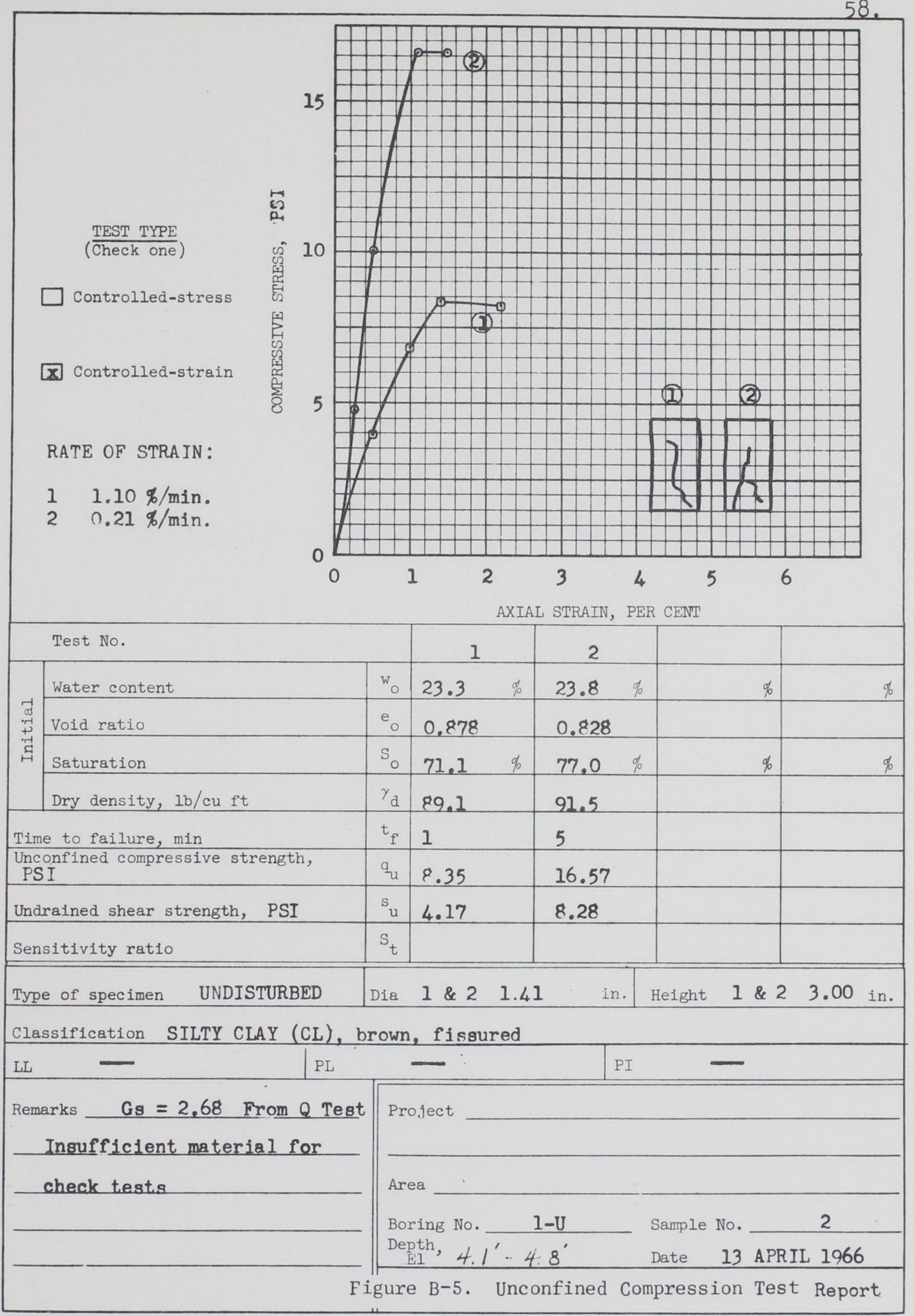




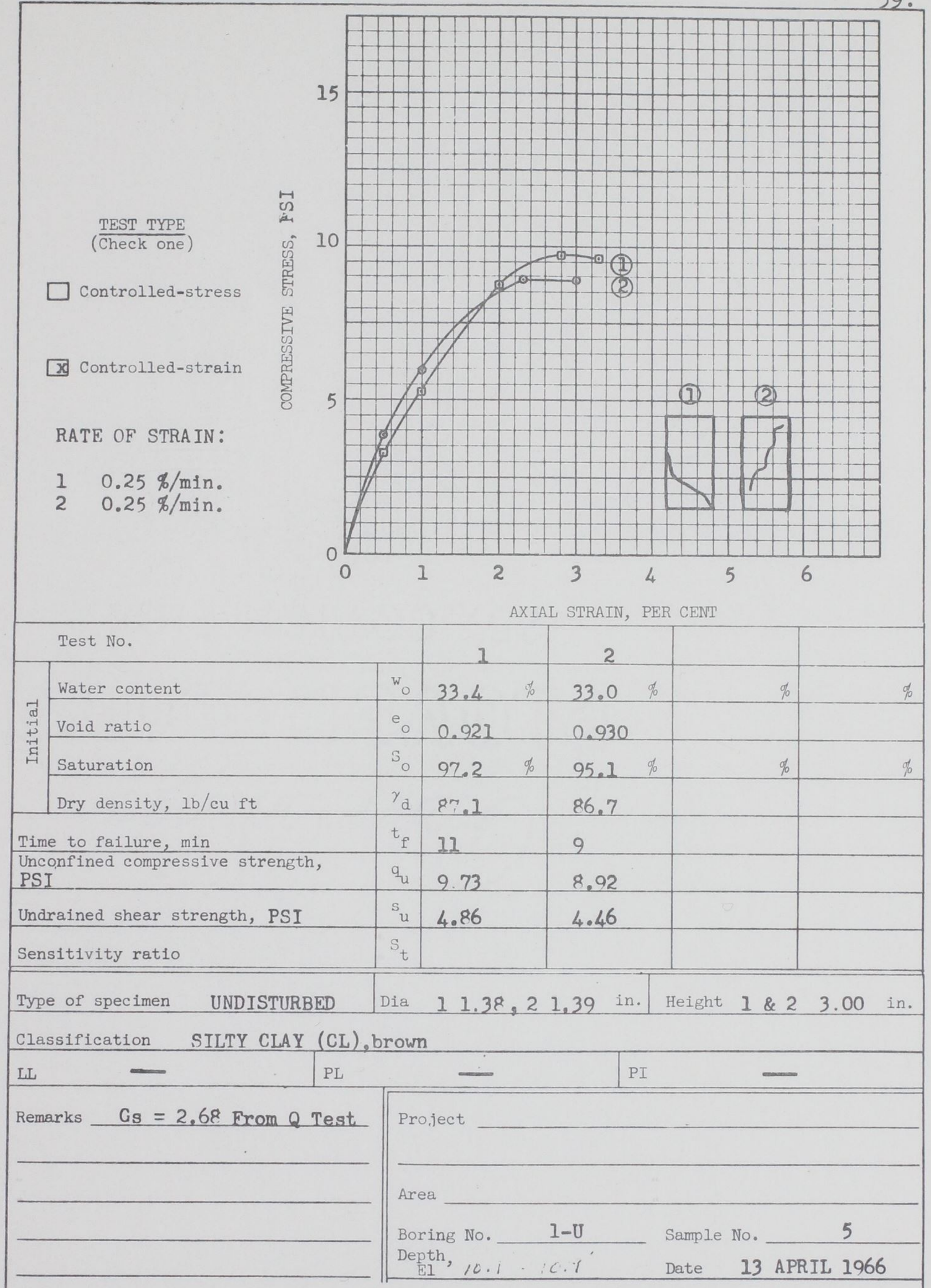

Figure B-6. Unconfined Compression Test Report 
60.

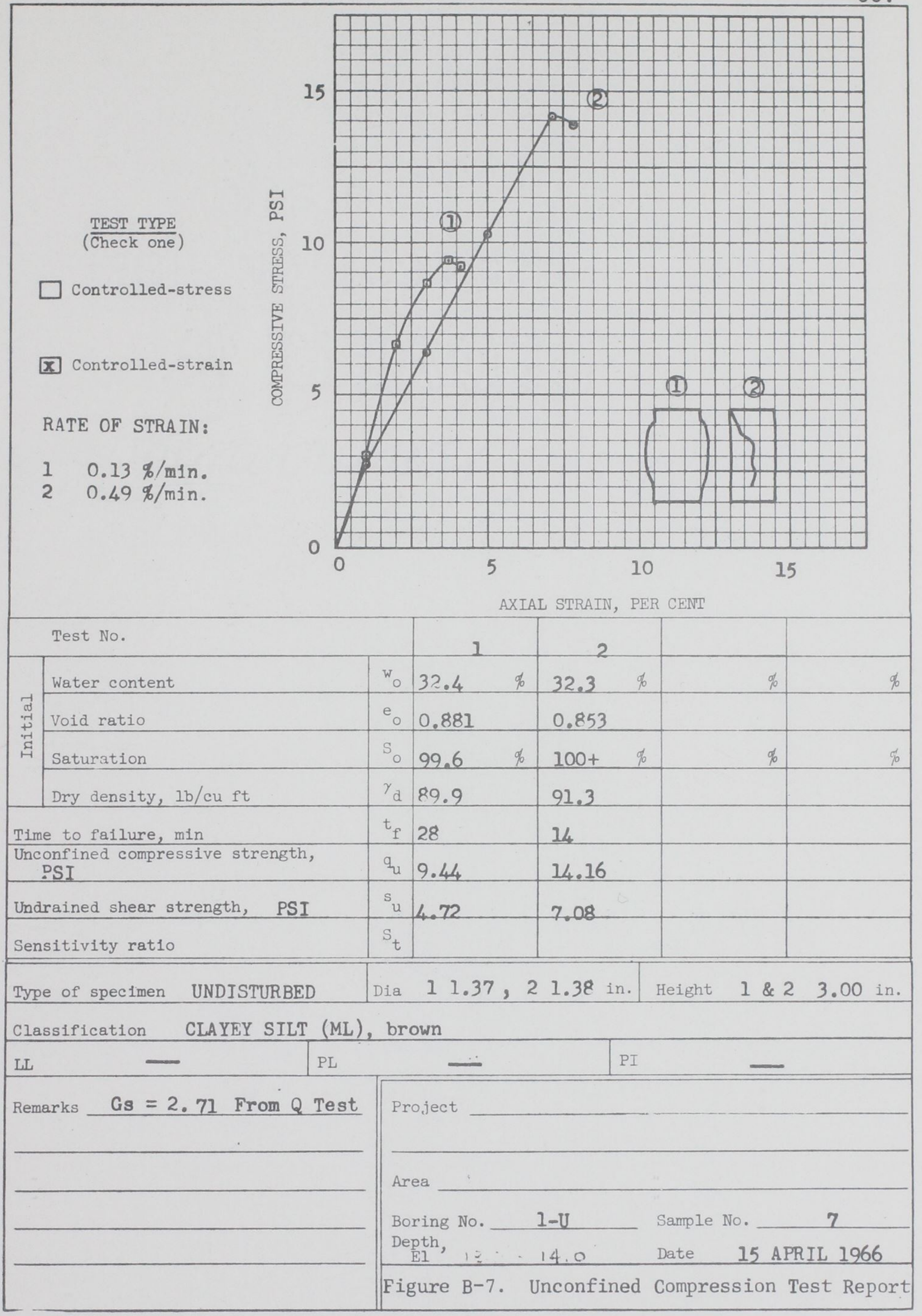


61.

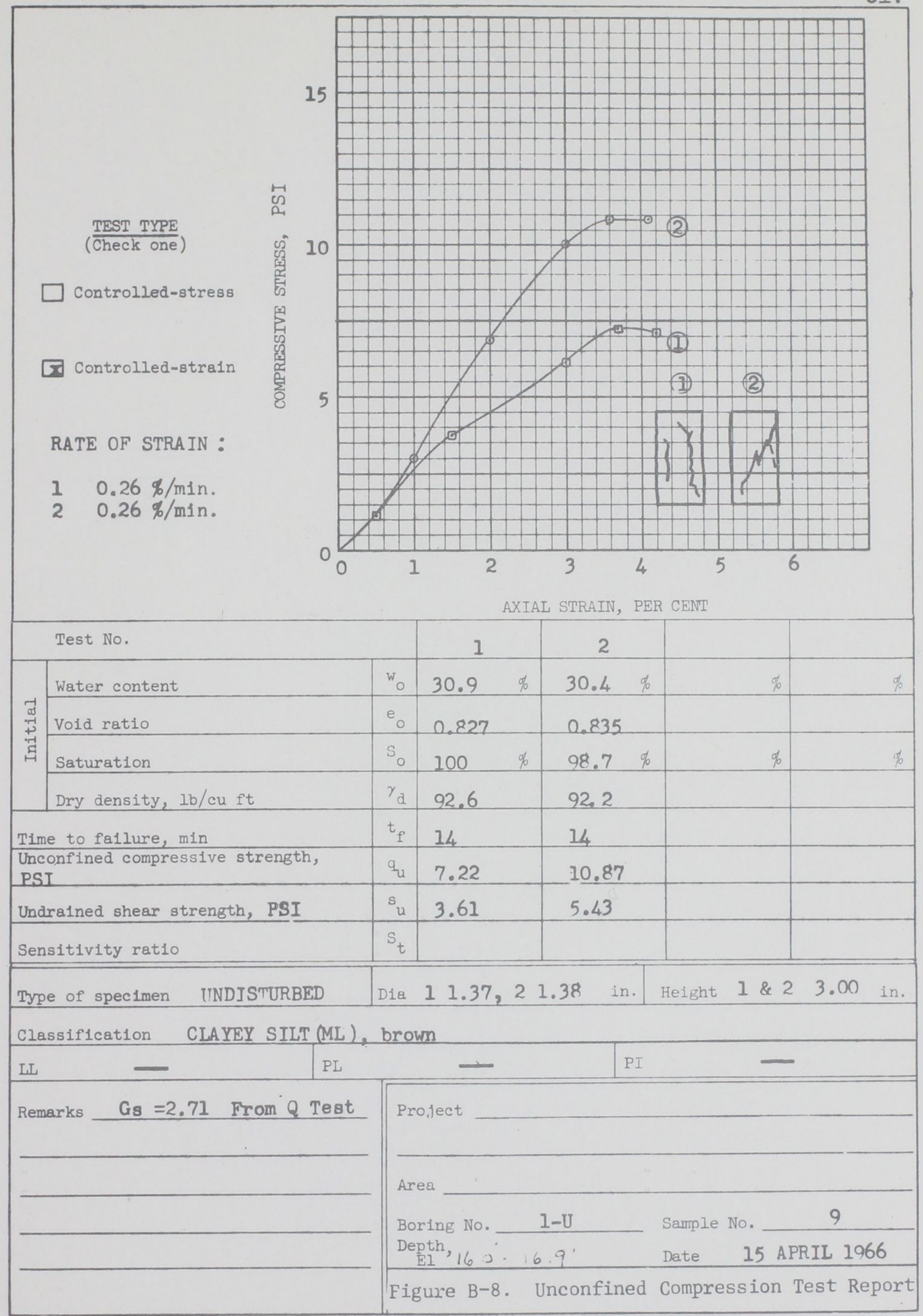




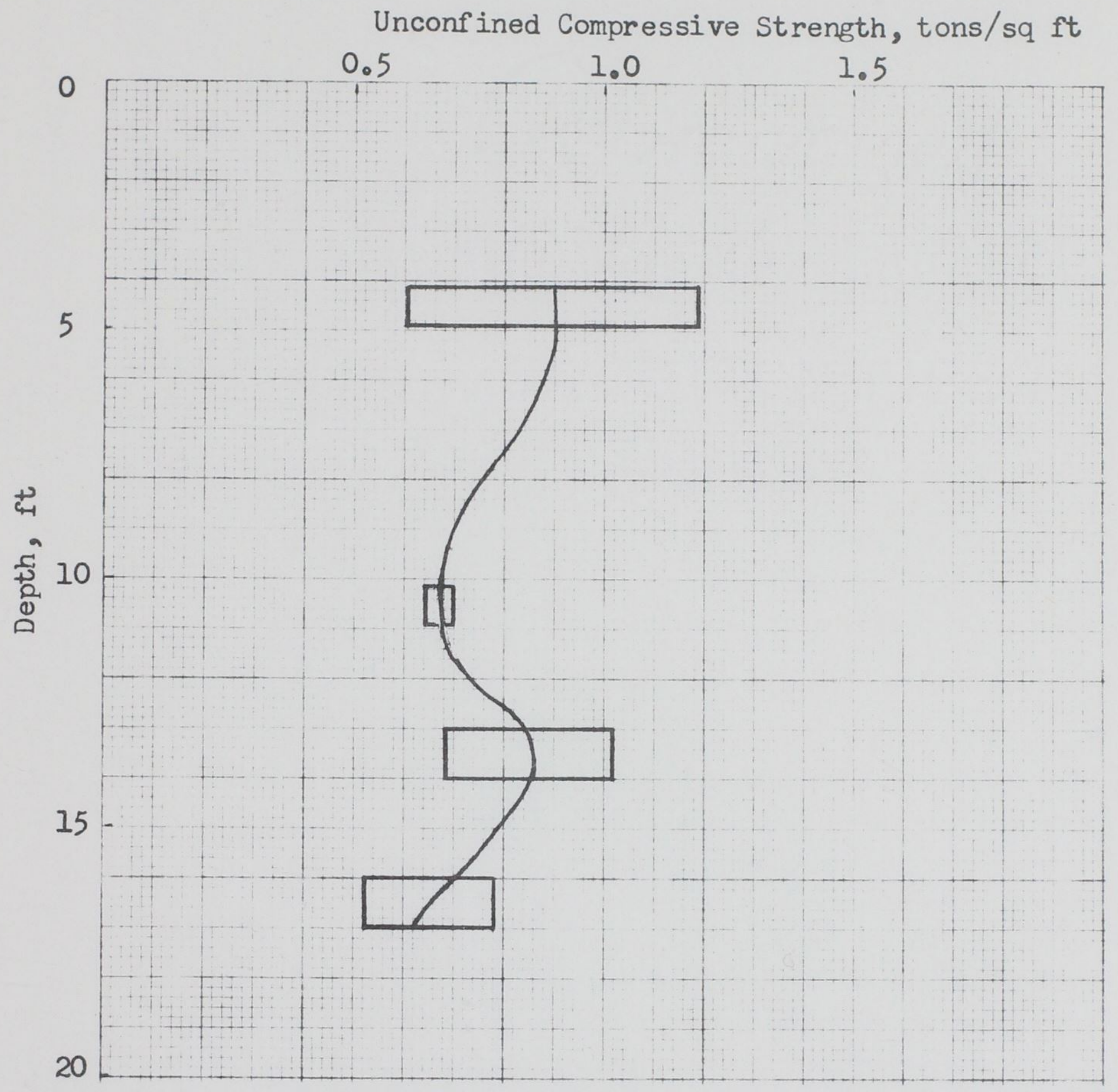

Figure B-9. Unconfined Compressive Strength Versus Depth 


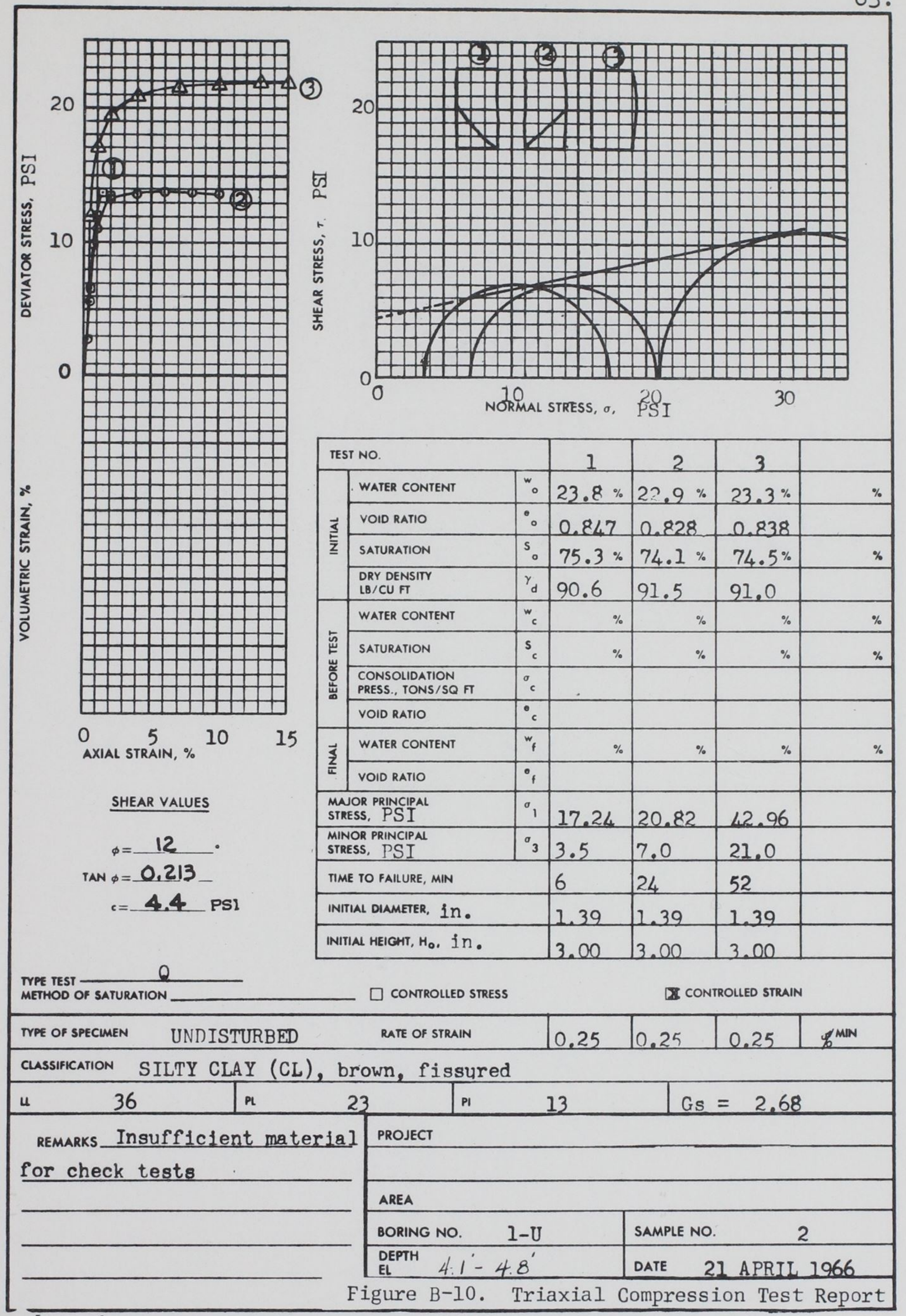




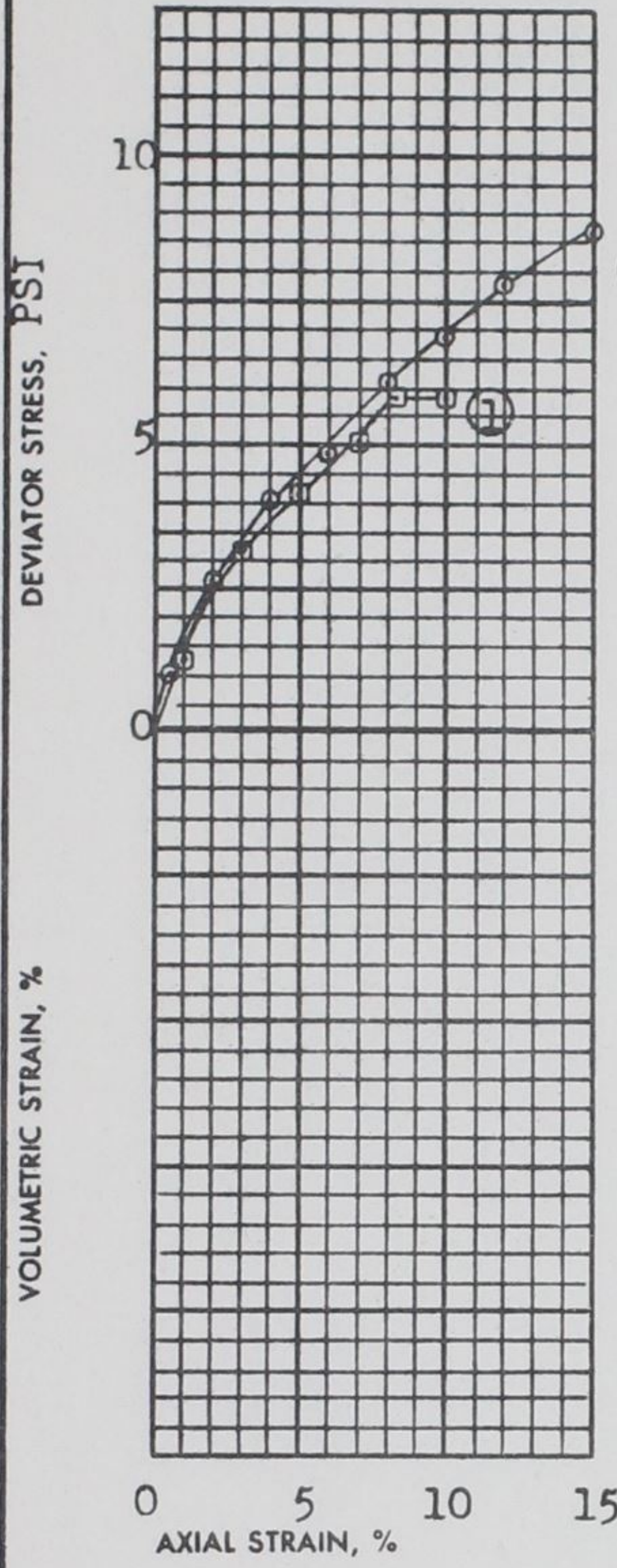

$$
\begin{aligned}
& \text { SHEAR VALUES } \\
& \phi=5^{\circ} . \\
& \operatorname{TAN} \phi=0.087 \\
& c=2.2 \text { PSI }
\end{aligned}
$$

\begin{tabular}{|c|c|c|c|c|c|c|}
\hline \multicolumn{3}{|c|}{ TEST NO. } & 1 & 2 & & \\
\hline \multirow{4}{*}{$\underline{\underline{z}}$} & WATER CONTENT & "。 & $28.0 \%$ & $28.0 \%$ & $\%$ & $\%$ \\
\hline & VOID RATIO & $\therefore$ & 0.797 & 0.791 & & \\
\hline & SATURATION & s。 & $94.2 \%$ & $94.9 \%$ & $\%$ & $\%$ \\
\hline & $\begin{array}{l}\text { DRY DENSITY } \\
\text { LB/CU FT }\end{array}$ & $\gamma_{d}$ & 93.1 & 93.4 & & \\
\hline \multirow{4}{*}{ 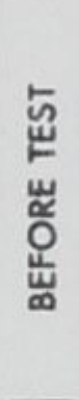 } & WATER CONTENT & $w_{c}$ & $\%$ & $\%$ & $\%$ & $\%$ \\
\hline & SATURATION & $s_{c}$ & $\%$ & $\%$ & $\%$ & $\%$ \\
\hline & $\begin{array}{l}\text { CONSOUDATION } \\
\text { PRESS., TONS/SQ FT }\end{array}$ & ${ }^{\circ}{ }_{c}$ & & & & \\
\hline & VOID RATIO & ${ }^{\circ}{ }_{C}$ & & & & \\
\hline \multirow{2}{*}{$\frac{\vec{z}}{\frac{3}{2}}$} & WATER CONTENT & $w_{f}$ & $\%$ & $\%$ & $\%$ & $\%$ \\
\hline & VOID RATIO & ${ }^{\circ} \mathrm{f}$ & & & & \\
\hline \multicolumn{2}{|c|}{$\begin{array}{l}\text { MAOR PRINCIPAL } \\
\text { STRESS, PSI }\end{array}$} & $\sigma_{1}$ & 12.06 & 29.67 & & \\
\hline \multicolumn{2}{|c|}{$\begin{array}{l}\text { MINOR PRINCIPAL } \\
\text { STRESS, PSI }\end{array}$} & $\sigma_{3}$ & 6.2 & 21.0 & & \\
\hline \multicolumn{3}{|c|}{ TIME TO FAILURE, MIN } & 33 & 60 & & \\
\hline \multicolumn{3}{|c|}{ INITIAL DIAMETER, in. } & 1.38 & 1.37 & & \\
\hline \multicolumn{3}{|c|}{ INITIAL HEIGHT, Ho, in. } & 3.00 & & & \\
\hline
\end{tabular}

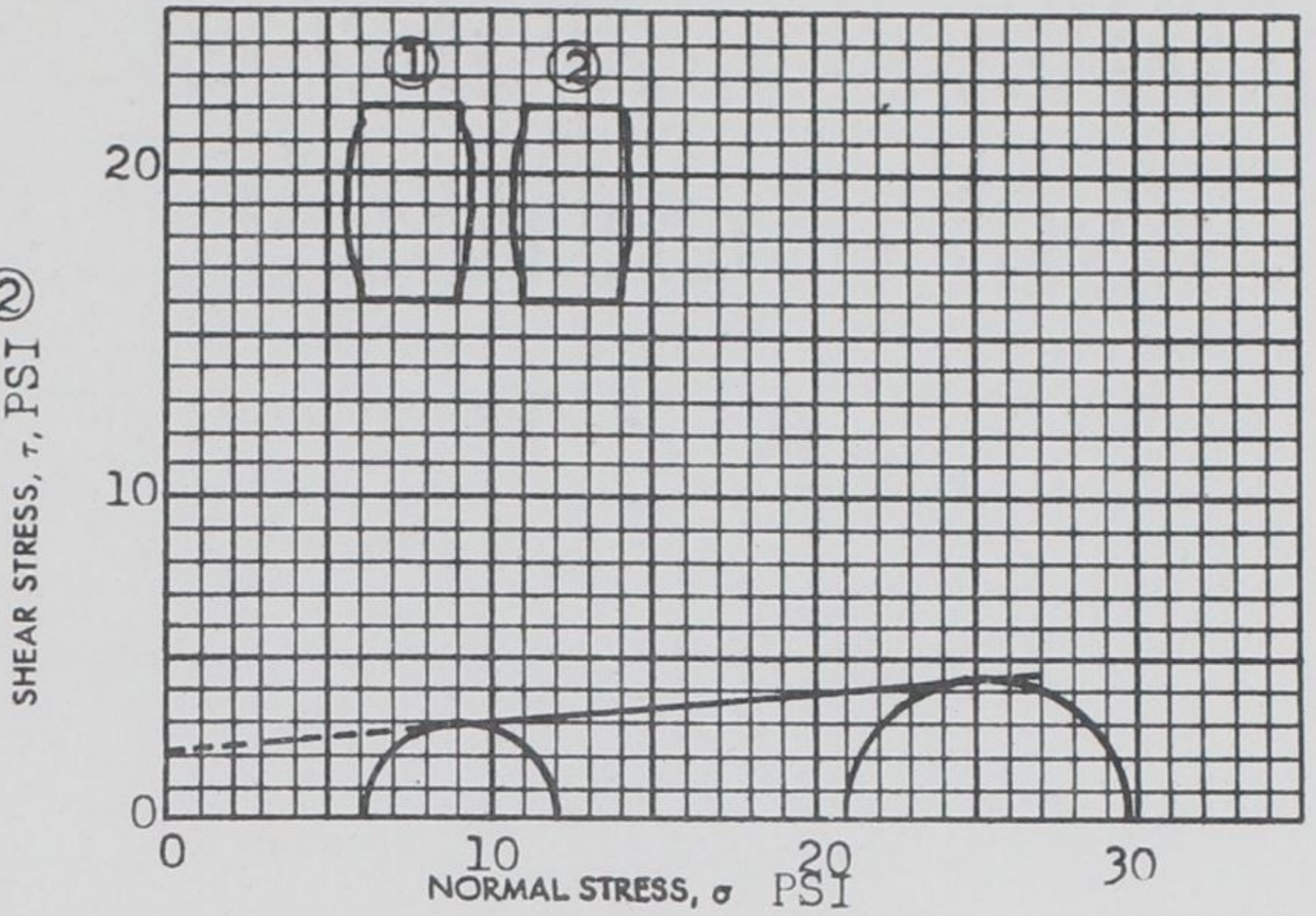

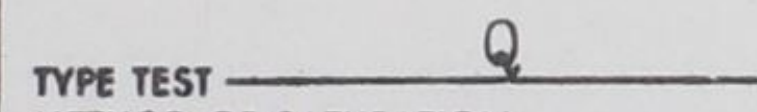

$\square$ CONTROLLED STRESS

I9 CONTROLLED STRAIN

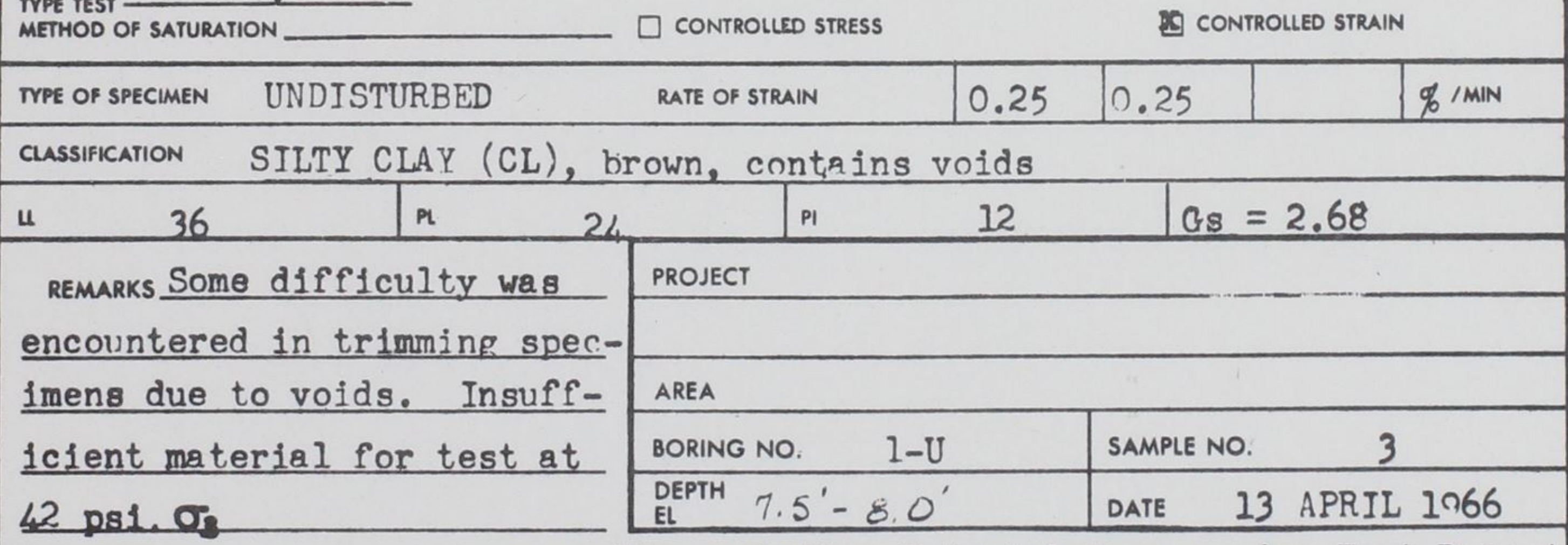

Figure B-ll. Triaxial Compression Test Report 


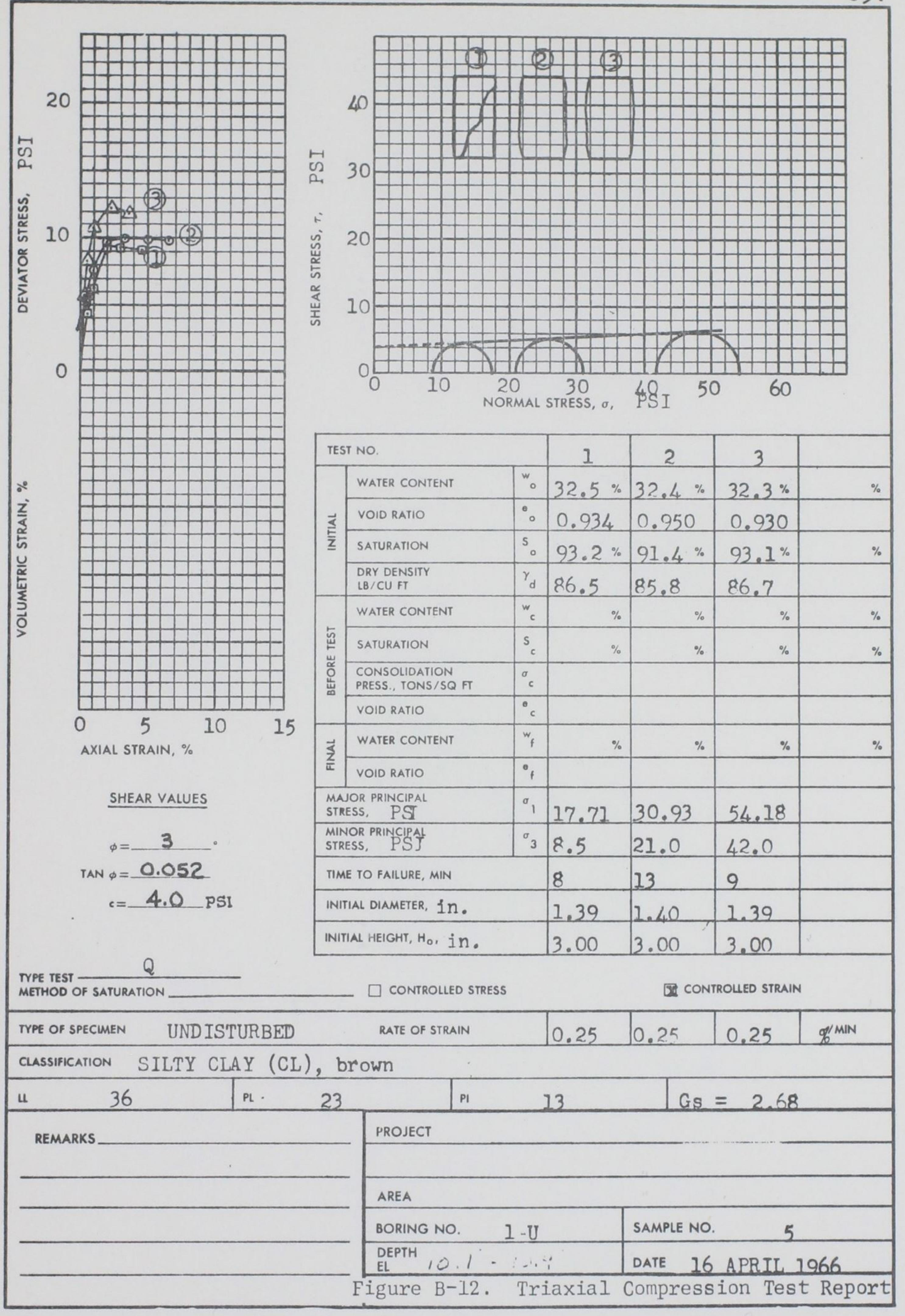




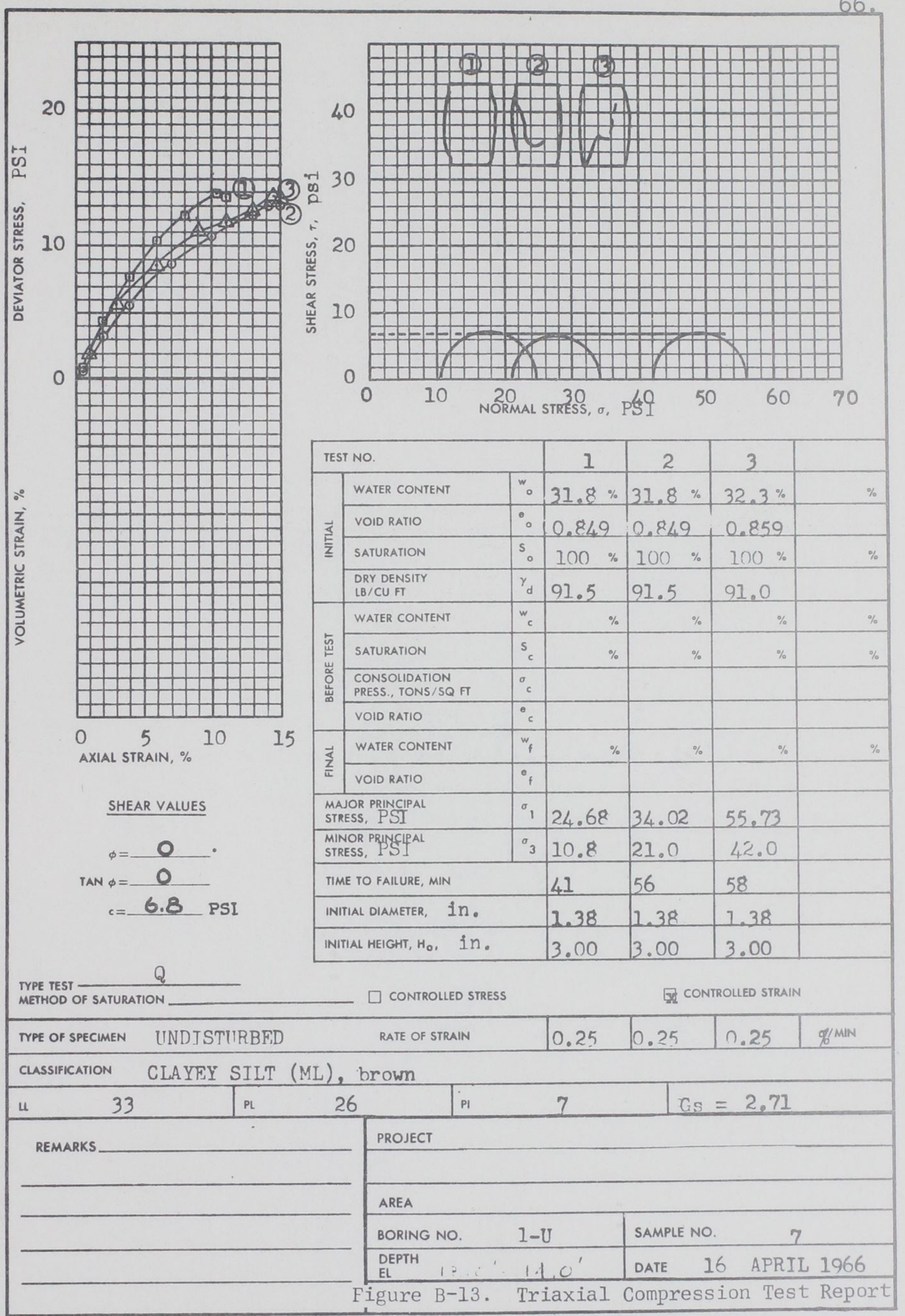


67.

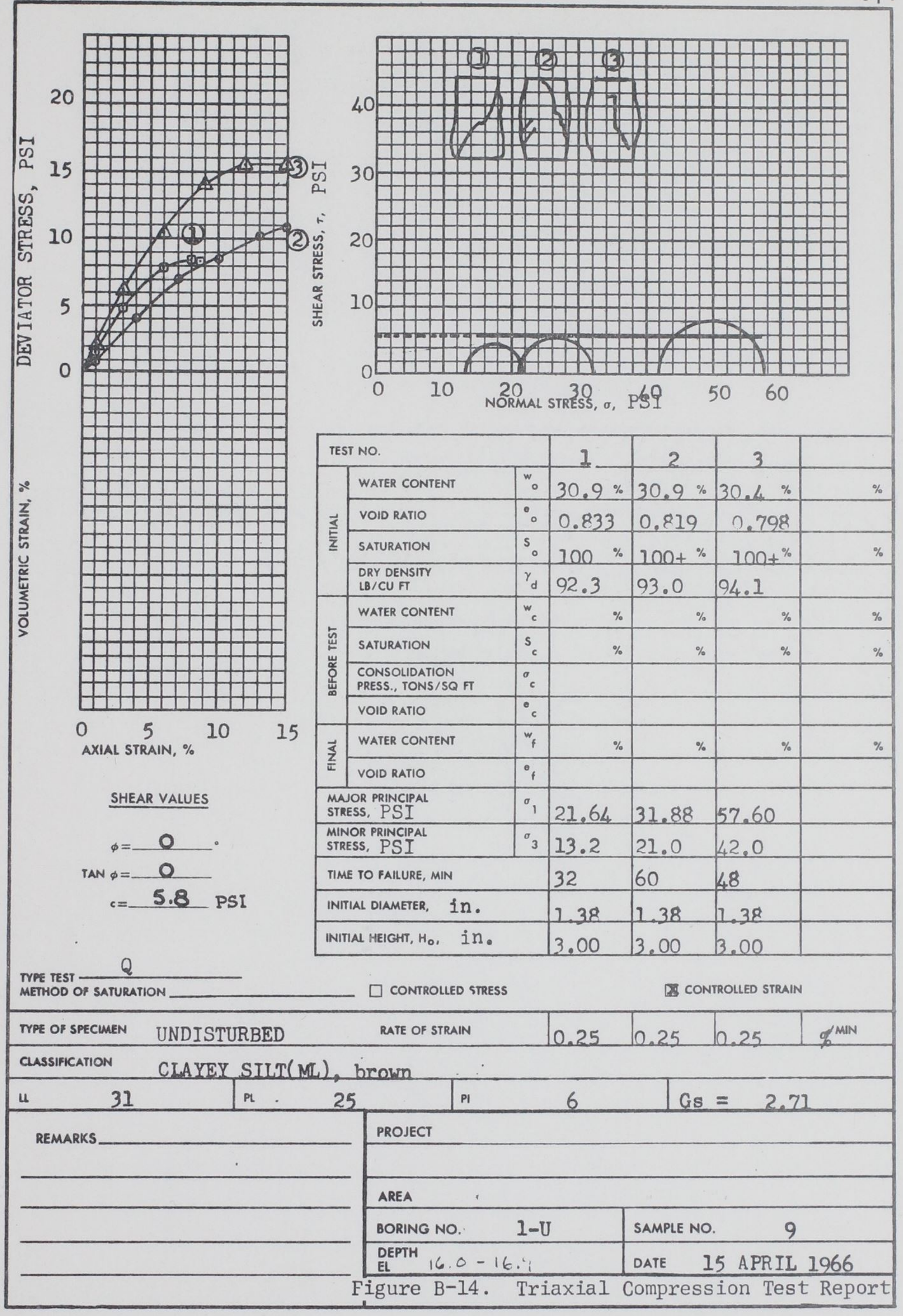




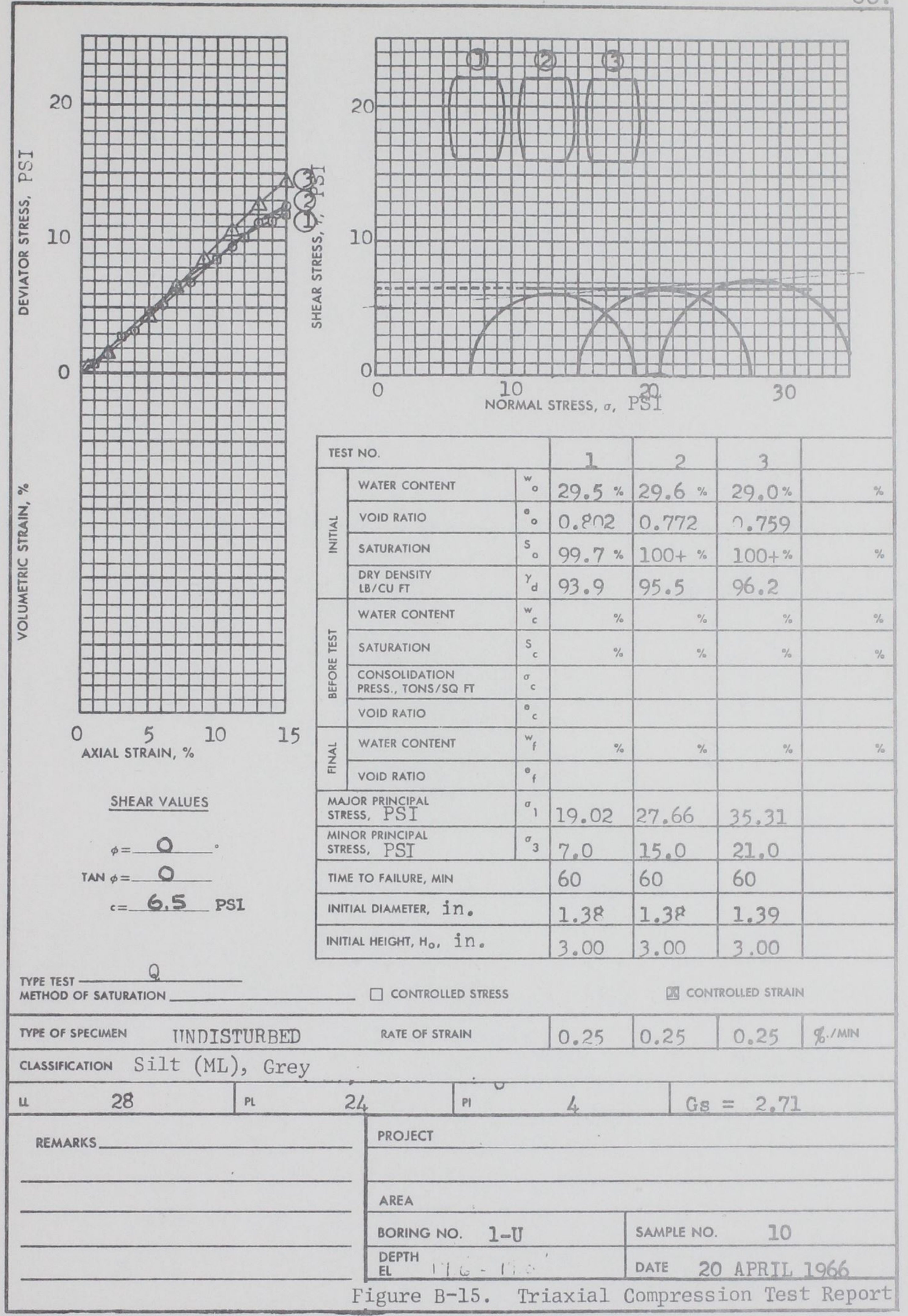




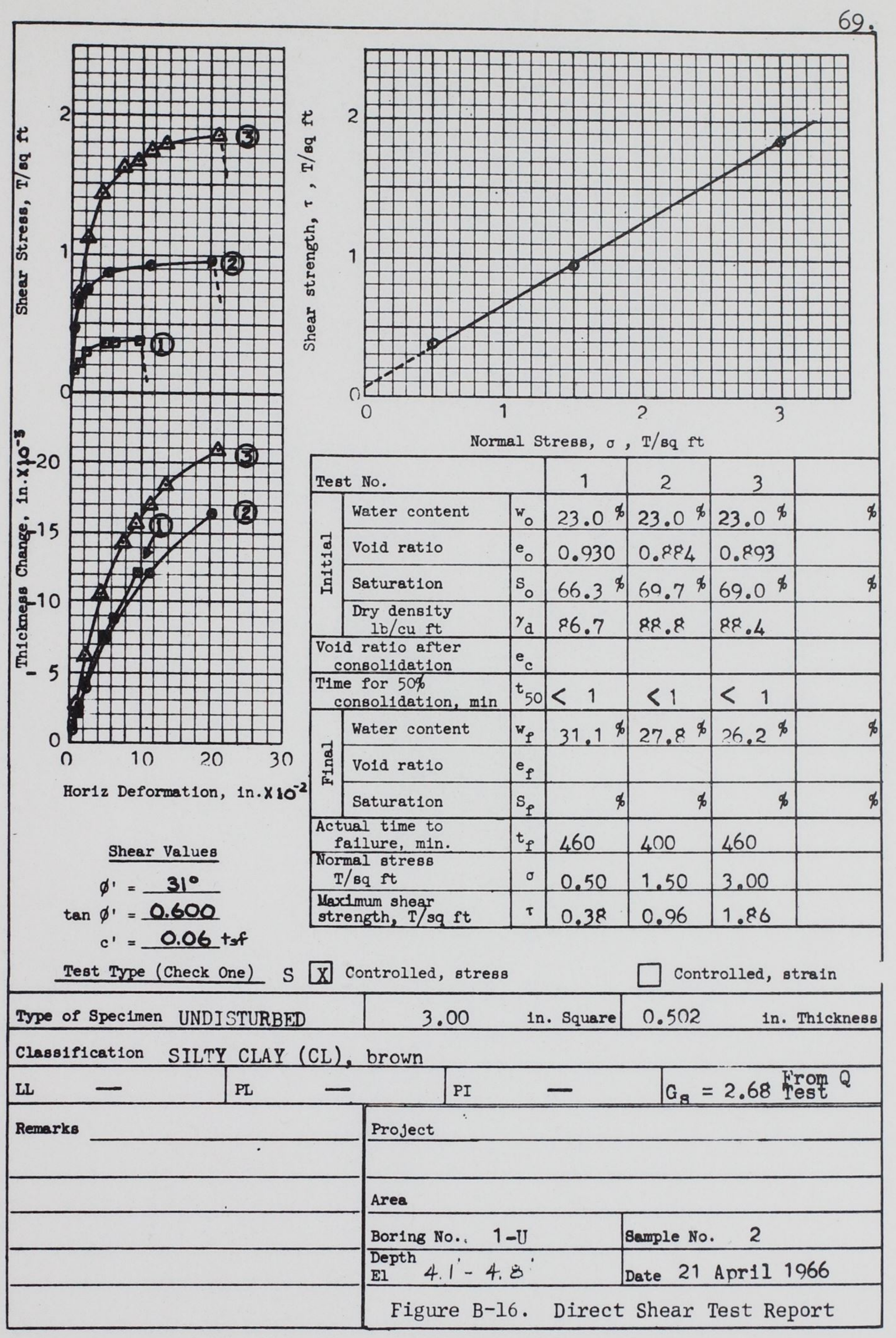


70.
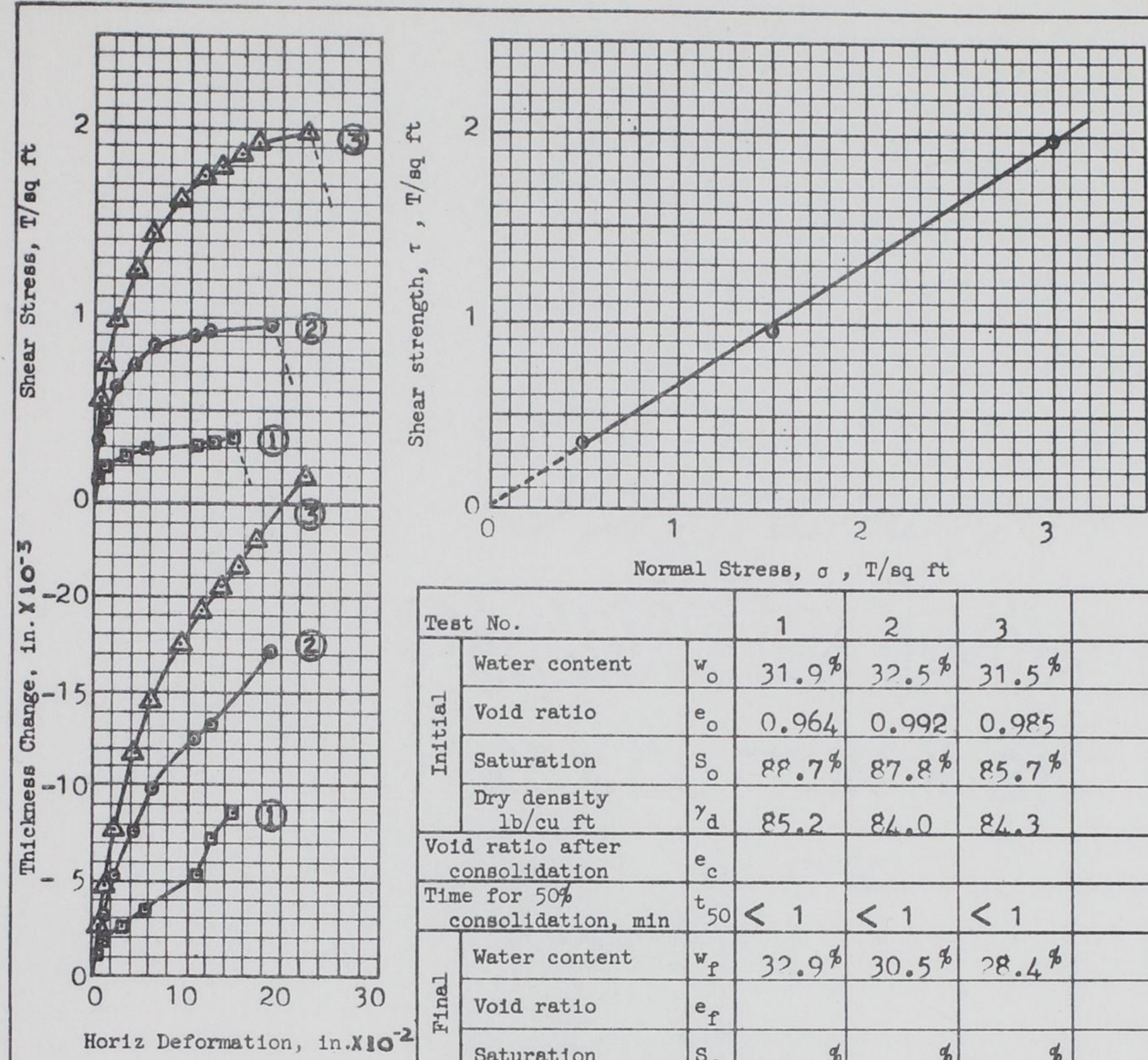

\begin{tabular}{|c|c|c|c|c|c|c|}
\hline \multicolumn{3}{|c|}{ Test No. } & 1 & 2 & 3 & \\
\hline \multirow{4}{*}{ 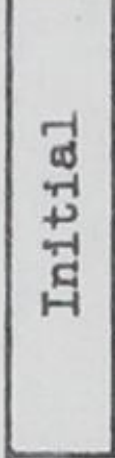 } & Water content & $w_{0}$ & $31.9 \%$ & $37.5 \%$ & $31.5^{\%}$ & क \\
\hline & Vo1d ratio & $e_{0}$ & 0.964 & 0.992 & 0.985 & \\
\hline & Saturation & $\mathrm{s}_{0}$ & $89.7 \%$ & $87.8^{\%}$ & $85.7 \%$ & क \\
\hline & $\begin{array}{l}\text { Dry density } \\
\text { lb/cu ft }\end{array}$ & $\gamma_{d}$ & 85.2 & 8h. 0 & 84.3 & \\
\hline \multicolumn{2}{|c|}{$\begin{array}{c}\text { Vo1d rat1o after } \\
\text { consolidation }\end{array}$} & $e_{c}$ & & & & \\
\hline \multicolumn{2}{|c|}{$\begin{array}{l}\text { Time for } 50 \% \\
\text { consolidation, min }\end{array}$} & $t_{50}$ & $<1$ & $<1$ & $<1$ & \\
\hline \multirow{3}{*}{ 离 } & Water content & $w^{f}$ & $37.9 \%$ & $30.5^{x}$ & $28.4^{\%}$ & $\phi$ \\
\hline & Vo1d rat1o & $e_{f}$ & & & & \\
\hline & Saturation & $S_{p}$ & का & क & \% & क \\
\hline \multicolumn{2}{|c|}{$\begin{array}{l}\text { Actual time to } \\
\text { Pallure, min. }\end{array}$} & $t_{f}$ & 380 & 400 & 460 & \\
\hline \multicolumn{2}{|c|}{ 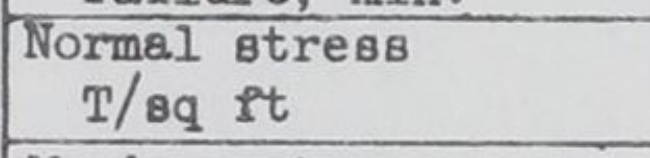 } & $\sigma$ & 0.50 & 1.50 & 3.00 & \\
\hline \multicolumn{2}{|c|}{$\begin{array}{l}\text { Laximum shegr } \\
\text { strength, } \mathrm{T} / \mathrm{sq} \mathrm{ft}\end{array}$} & $\tau$ & 0.35 & 0.96 & 1.98 & \\
\hline
\end{tabular}

Test Type (Check One) S $\mathrm{X}$ Controlled, stress

$\square$ Controlled, strain

\begin{tabular}{|l|ll|ll|}
\hline Type of Specimen UNDISTURBED & 3.00 & in. Square & 0.502 & in. Thickness \\
\hline
\end{tabular}

Classification SILTY CLAY (CL), brown

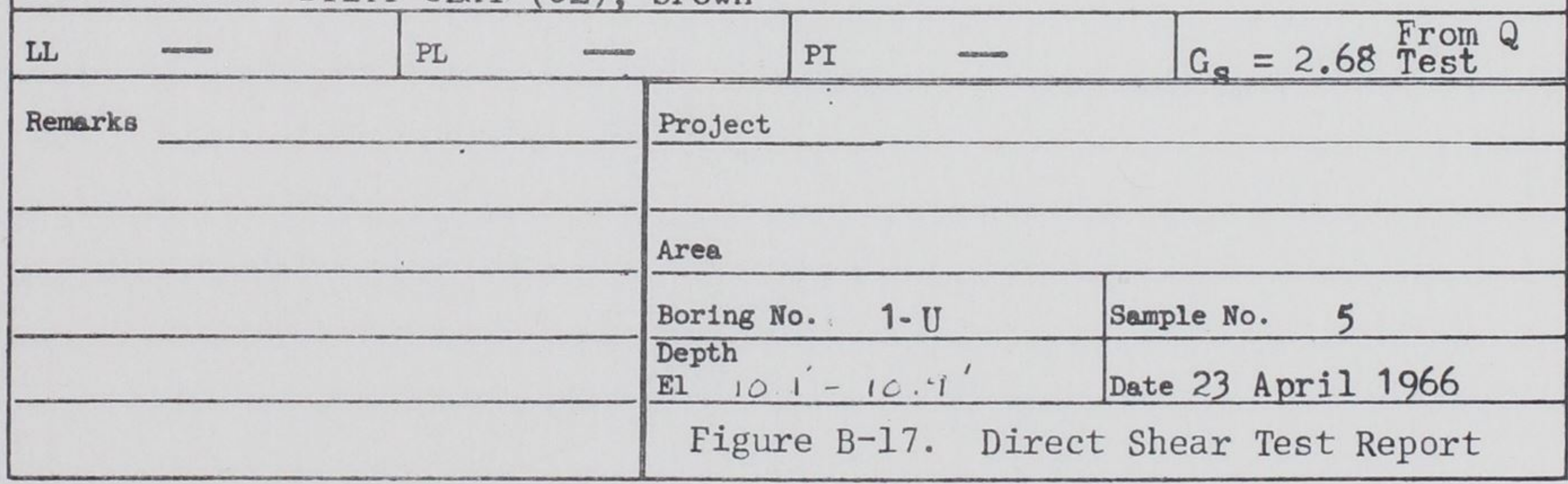




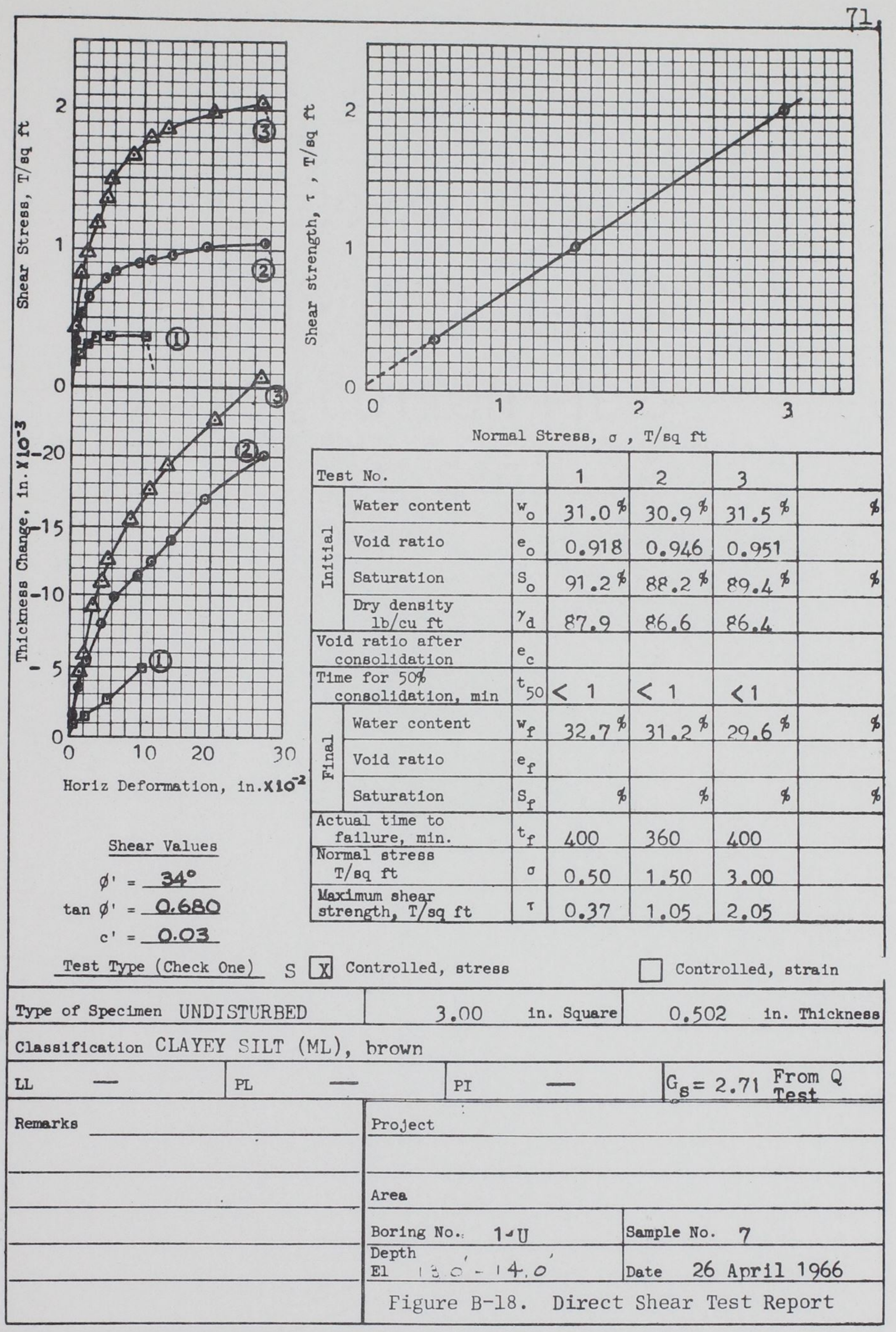



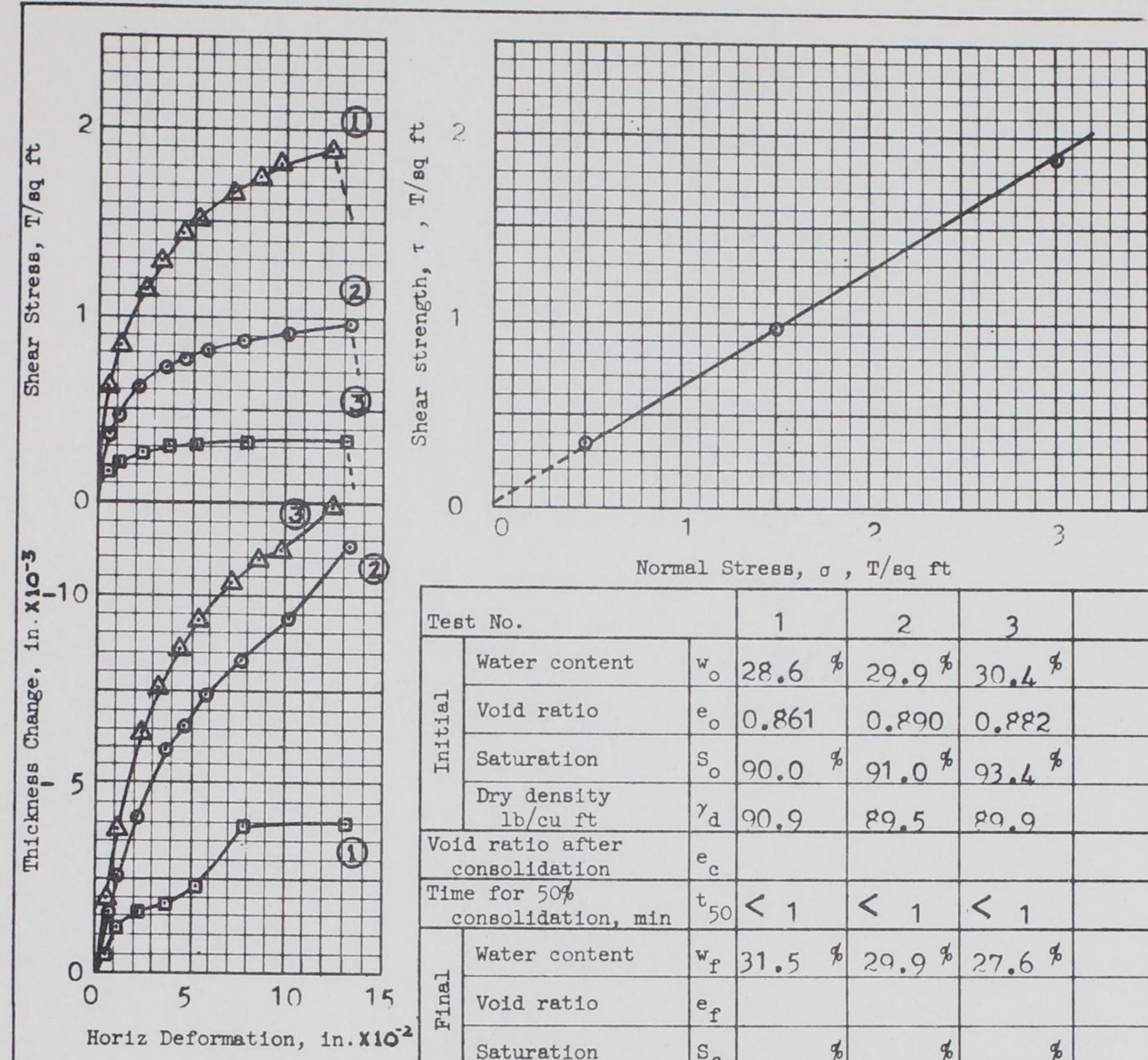

\begin{tabular}{|c|c|c|c|c|c|c|}
\hline \multicolumn{3}{|c|}{ Test No. } & 1 & 2 & 3 & \\
\hline \multirow{4}{*}{ 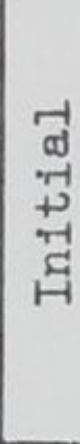 } & Water content & $w_{0}$ & $28.6 \%$ & $29.9^{\%}$ & $30.4^{\%}$ & \% \\
\hline & Vold ratio & $e_{0}$ & 0.861 & 0.890 & 0.882 & \\
\hline & Saturation & $\mathrm{s}_{0}$ & $90.0 \%$ & $91.0^{\%}$ & $93.4^{\%}$ & क \\
\hline & $\begin{array}{l}\text { Dry density } \\
\mathrm{Ib} / \mathrm{cu} \mathrm{ft}\end{array}$ & $\gamma_{d}$ & 90.9 & 89.5 & 90.9 & \\
\hline \multicolumn{2}{|c|}{$\begin{array}{l}\text { Vold ratio after } \\
\text { consolidation }\end{array}$} & $e_{c}$ & & & & \\
\hline \multicolumn{2}{|c|}{$\begin{array}{l}\text { Time for } 50 \% \\
\text { consolidation, min }\end{array}$} & $t_{50}$ & $<1$ & $<1$ & $<1$ & \\
\hline \multirow{3}{*}{$\sum_{i=1}^{\infty}$} & Water content & $w^{f}$ & $31.5 \%$ & $29.9^{\%}$ & $27.6 \%$ & क \\
\hline & Vold rat1o & $e_{f}$ & & & & \\
\hline & Saturat1on & $s_{p}$ & का & $\%$ & $\%$ & क \\
\hline \multicolumn{2}{|c|}{$\begin{array}{l}\frac{1}{\text { Actual time to }} \\
\text { fallure, min. }\end{array}$} & $t_{f}$ & 300 & 280 & 380 & \\
\hline \multicolumn{2}{|c|}{$\begin{array}{l}\text { Normal stress } \\
\mathrm{T} / \mathrm{sq} \mathrm{ft}\end{array}$} & $\sigma$ & 0.50 & 1.50 & 3.00 & \\
\hline \multicolumn{2}{|c|}{$\begin{array}{l}\text { Maximum shear } \\
\text { strength, T/sq } \mathrm{ft}\end{array}$} & $\tau$ & 0.34 & 0.97 & 1.88 & \\
\hline
\end{tabular}

$$
\begin{aligned}
\frac{\text { Shear Values }}{32^{\circ}} & \\
\phi^{\prime} & =\frac{0.630}{\tan \phi^{\prime}}=\frac{0.630}{0.02} \\
c^{\prime} & =0.02
\end{aligned}
$$

$\square$ Controlled, strain

Test Type (Check One) S X Controlled, stress

\begin{tabular}{|l|ll|ll|}
\hline Type of Specimen UNDISTURBED & 3.00 & 1n. Square & 0.502 & in. Thickness \\
\hline
\end{tabular}

Clase1fication CLA YEY SILT (ML), brown

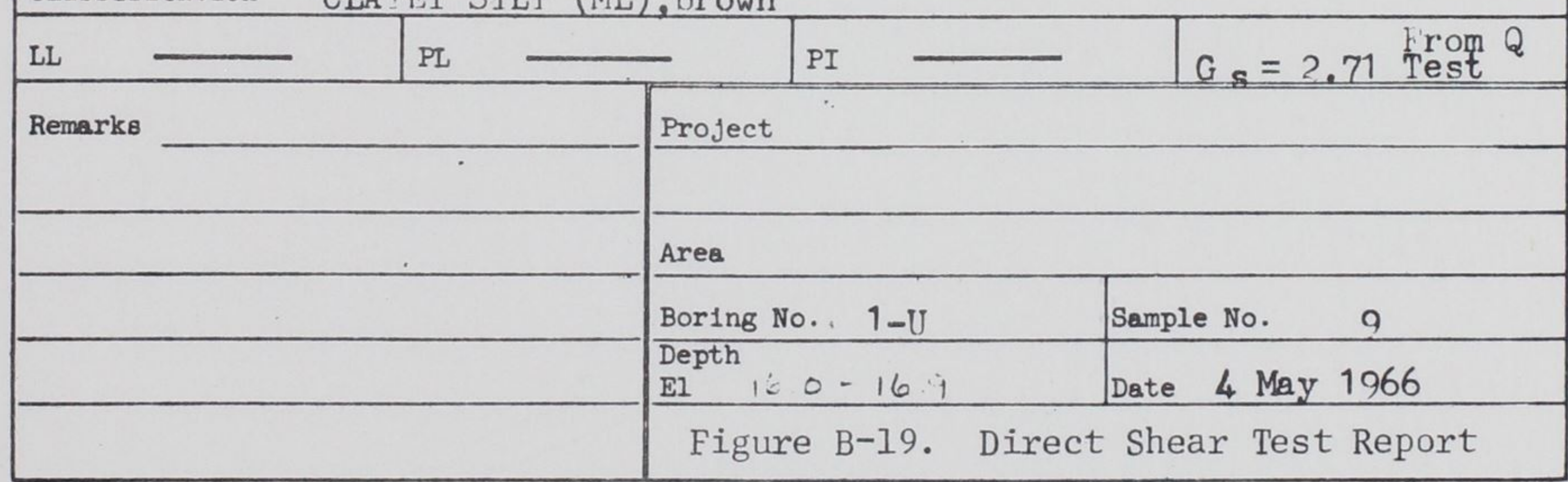




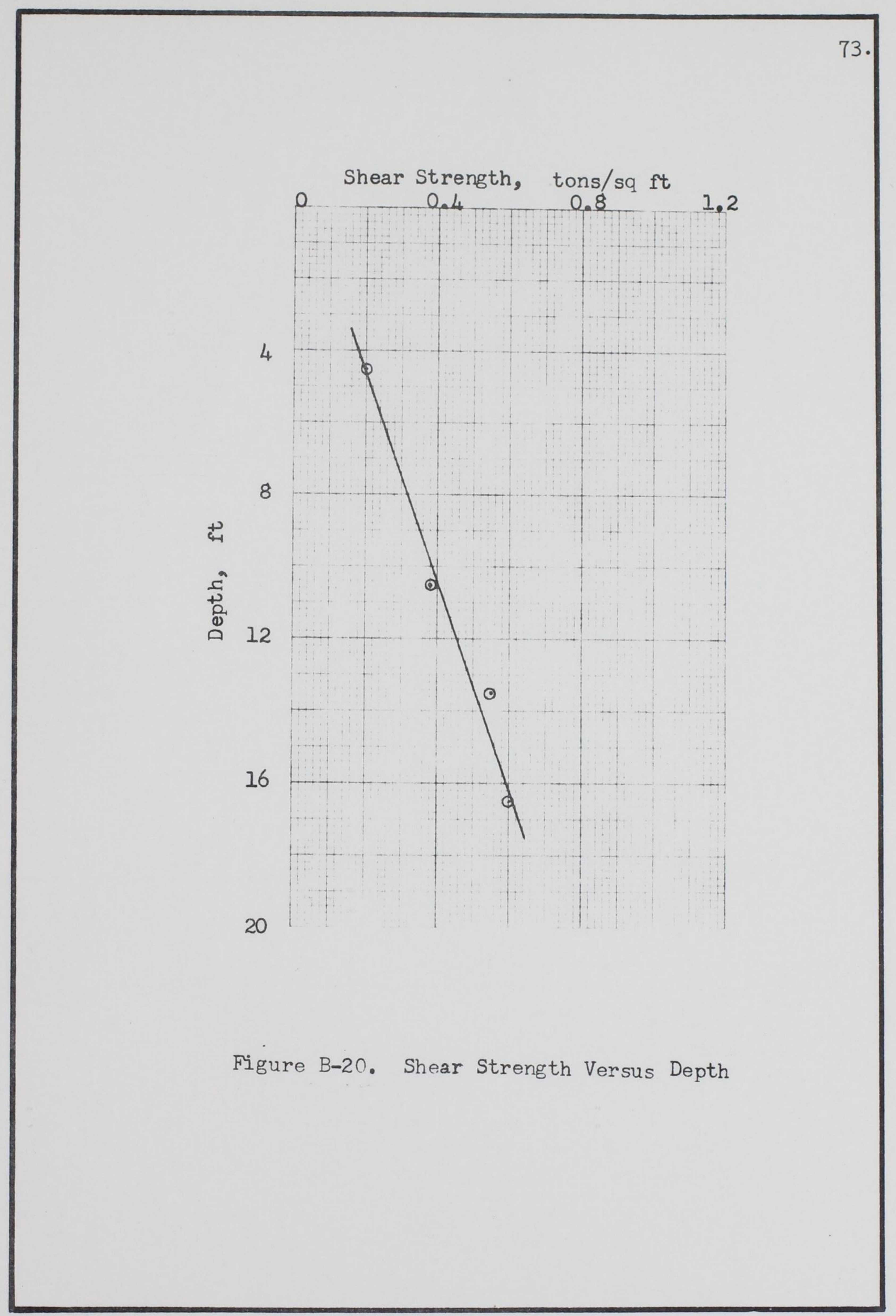


APPENDIX C

DYNAMIC LABORATORY AND FIELD TESTS 


\section{APPENDIX C \\ DYNAMIC LABORATORY AND FIELD TESTS}

\section{Dynamic Laboratory Tests}

Vibratory tests were conducted on four undisturbed soil specimens in the WES soil dynamics laboratory to determine dynamic moduli for comparison with those moduli determined in the field. The test procedure and apparatus are described in detail in U. S. Army Material Command Cold Regions Research and Engineering Laboratory (CRREL) Technical Report No. 173, "Measurement of Complex Moduli and Damping of Soils under Dynamic Loads: Laboratory Test Apparatus, Procedure, and Analysis."

The test procedure is referred to as the resonant column technique. When this method is used, the sample response is monitored for a range of frequencies in both the longitudinal and torsional modes of excitation to determine the resonant frequency of the soil column. The fundamental resonant frequency of the sample is assumed to be the lowest frequency at which the ratio of the acceleration at the top of the sample to that at the bottom of the sample is a maximum, and the phase angle between the sine wave at the top and bottom of the sample approaches $90 \mathrm{deg}$. The desired dynamic soil properties can then be found by means of the following relations:

$$
\begin{aligned}
G & =16 f_{t}^{2} L^{2} \rho \\
E & =16 f_{1}^{2} L^{2} \rho \\
v_{S} & =4 f_{t} L
\end{aligned}
$$




$$
\begin{aligned}
& v_{1}=r_{1} L \\
& \left.v_{c}=v_{1}\left(\frac{1-v}{(1+v)(1-2 v)}\right)\right)^{1 / 2} \\
& \nu=\frac{E}{2 G}-1
\end{aligned}
$$

where

$$
\begin{aligned}
G & =\text { shear modulus } \\
f_{t} & =\text { fundamental torsional resonant frequency } \\
L & =\text { length of the sample } \\
\rho & =\text { mass density of the sample } \\
E & =\text { compression (Young's) modulus } \\
f_{I} & =\text { fundamental longitudinal resonant frequency } \\
v_{S} & =\text { shear wave velocity } \\
v_{I} & =\text { longitudinal wave velocity } \\
v_{c} & =\text { compression wave velocity } \\
\nu & =\text { Poisson's ratio }
\end{aligned}
$$

The equations given above are simplified versions that consider the elastic case only. Equations are available, however, that consider the soil to be a viscoelastic material and yield a value for the damping property and values of moduli and velocity that account for material damping.

The results obtained from this type of laboratory test, like those obtained from any other conventional laboratory tests, are dependent upon the quality and representativeness of the sample. Ideally, it is desirable to have undisturbed samples; if the samples 
are remolded, the water content and density should be the same as those of the undisturbed material. Also, the stress conditions for either the undisturbed or remolded sample should be the same as those for the material in situ. Under most circumstances, it is generally impossible to obtain an accurate estimate of the state of stress of either in situ material or remolded specimens. Therefore, in situ residual stresses generally are not reproduced in remolded samples, and the confining pressure for the laboratory specimens can only approximate that for the in situ material.

The test specimens, $4 \mathrm{in}$. in diam and about $15 \mathrm{in.}$ long, were inclosed in a rubber membrane and placed upright in a triaxial chamber. Confining pressure was applied by gas pressure in the chamber. The tests were conducted by vibrating each specimen from the bottom in longitudinal and torsional modes and measuring the amplitudes of the induced waves by means of accelerometers attached to the bottom and top of specimen. Velocities and moduli were then calculated from the ratio of the amplitudes measured by the top and bottom accelerometers, the specimen length, and wave frequency at resonance.

Four undisturbed soil specimens from hole 1 (described in Appen$\operatorname{dix} B)$ were tested at confining pressures representative of the pressure of overburden material to a depth of about $22 \mathrm{ft}$ from the ground surface.

The data obtained from the dynamic laboratory tests are plotted in figure $\mathrm{C}-1$ as the laboratory moduli versus depth. The average 
laboratory shear moduli for samples from the ground surface to a depth of $22 \mathrm{ft}$ ranged from 4200 to 8000 psi. Poisson's ratio varied from 0.37 to 0.49 .

\section{Field Tests}

\section{$\underline{\text { Refraction Seismic Tests }}$}

Refraction seismic tests were conducted to determine the compression-wave velocity of the soil in the test area. The compression-wave velocity and the shear-wave velocity are used together in determining Poisson's ratio and the elastic moduli of the soil. This method is outlined in Appendix A.

Four seismic lines run in the test area, shown in figure C-2, were oriented in north, south, east, and west directions. A geophone was placed on the ground surface near the boreholes, and a signal was produced by striking a circular steel plate with a sledgehammer. The steel plate was placed on the ground at various distances measured from the geophone, and the test repeated. The compression-wave velocity was computed from the time measured for the first wave arrival and the distance of the geophone from the energy source.

Compression-wave velocity data for the traverses are shown in table $\mathrm{C}-1$. The average velocity was about 1060 fps for an average depth of about $13 \mathrm{ft}$. The average compression-wave velocity in the second zone was approximately 4600 fps. A selected plot of time versus distance for a refraction seismic traverse is shown in 
figure C-3. Seismic traverses conducted during other tests near the test area indicated that the limestone layer was at a depth of about 125 ft and had a compression-wave velocity of about 10,000 fps. Vibration Test

A low-frequency, hydraulic motor-driven, eccentric-mass vibrator with a maximum force level of 10,000 Ibs and the capability of producing sinusoidal motion in the vertical direction within a frequency range of $1-50 \mathrm{~Hz}$ was used in determining the shear-wave velocities through the soil in accordance with the procedure outlined in Appendix A. A total of four vibration traverses, oriented north, south, east, and west, were conducted in the test area. Figure C-2 shows the relative location of the boreholes and vibrator and the direction of the traverses.

The shear-wave velocity data obtained from the four traverses are shown in table $\mathrm{C}-1$ and are plotted versus depth in figure $\mathrm{C}-4$. The data indicated that the average shear wave velocity increased very slightly from about 460 to $600 \mathrm{fps}$ between about 5 to $30 \mathrm{ft}$. Shear and Compression Moduli

Using the field data and the procedures described in Appendix A, shear and compression (Young's) moduli were calculated. These data are tabulated in table $\mathrm{C}-1$ and are plotted versus depth in figure $\mathrm{C}-5$. The average shear moduli increased uniformly from approximately 5500 to 9000 psi between depths of about 5 to $30 \mathrm{ft}$. The average compression moduli increased from about 15,000 psi at a depth of 5 ft to 
80.

about $27,000 \mathrm{psi}$ at a depth of $30 \mathrm{ft}$. Poisson's ratios ranged from 0.36 to 0.50 
Table C-1

In -Situ Soil Tests, WES Test Area

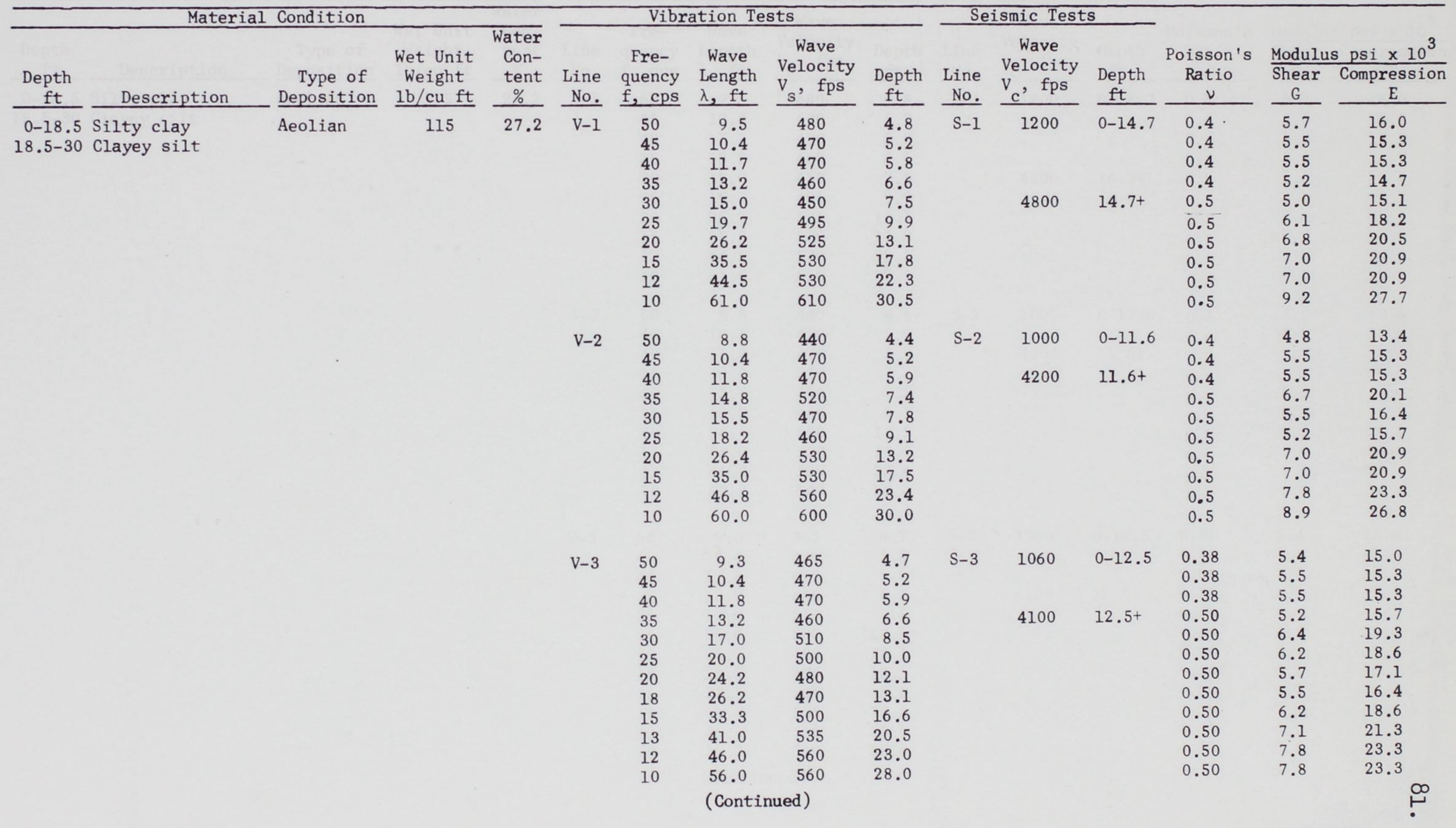


Table C-1 (Concluded)

\begin{tabular}{|c|c|c|c|c|c|c|c|c|c|c|c|c|c|c|c|}
\hline \multicolumn{5}{|c|}{ Material Condition } & \multicolumn{5}{|c|}{ Vibration Tests } & \multicolumn{3}{|c|}{ Seismic Tests } & \multirow[b]{2}{*}{$\begin{array}{c}\text { Poisson's } \\
\text { Ratio } \\
\nu \\
\end{array}$} & \\
\hline $\begin{array}{c}\text { Depth } \\
\mathrm{ft}\end{array}$ & Description & $\begin{array}{c}\text { Type of } \\
\text { Deposition }\end{array}$ & $\begin{array}{l}\text { Wet Unit } \\
\text { Weight } \\
\text { lb/cu ft } \\
\end{array}$ & $\begin{array}{c}\text { Water } \\
\text { Con- } \\
\text { tent } \\
\% \\
\end{array}$ & $\begin{array}{r}\text { Line } \\
\text { No. }\end{array}$ & $\begin{array}{l}\text { Fre- } \\
\text { quency } \\
\underline{\mathrm{f}, \mathrm{Hz}}\end{array}$ & $\begin{array}{l}\text { Wave } \\
\text { Length } \\
\lambda, \mathrm{ft} \\
\end{array}$ & $\begin{array}{l}\text { Wave } \\
\text { Velocity } \\
\mathrm{V}_{\mathrm{s}} \text {, fps } \\
\end{array}$ & $\begin{array}{l}\text { Depth } \\
\mathrm{ft} \\
\end{array}$ & $\begin{array}{l}\text { Line } \\
\text { No. }\end{array}$ & $\begin{array}{l}\text { Wave } \\
\text { Velocity } \\
v_{c}, \text { fps } \\
\end{array}$ & $\begin{array}{l}\text { Depth } \\
\mathrm{ft}\end{array}$ & & $\begin{array}{l}\text { Modulus } \\
\text { Shear } \\
\quad G \\
\end{array}$ & $\frac{\text { s psi } \times 10^{3}}{\text { Compression }} \frac{E}{E}$ \\
\hline $\begin{array}{r}0-18.5 \\
18.5-30\end{array}$ & $\begin{array}{l}\text { Silty clay } \\
\text { Clayey silt }\end{array}$ & Aeolian & 115 & 27.2 & V-4 & $\begin{array}{l}50 \\
45 \\
40 \\
35 \\
30 \\
25 \\
20 \\
18 \\
15 \\
13 \\
12 \\
10\end{array}$ & $\begin{array}{r}9.3 \\
10.2 \\
11.6 \\
13.6 \\
16.0 \\
21.2 \\
25.0 \\
29.8 \\
34.0 \\
41.5 \\
49.5 \\
61.4\end{array}$ & $\begin{array}{l}465 \\
460 \\
465 \\
475 \\
480 \\
508 \\
500 \\
536 \\
510 \\
541 \\
595 \\
614\end{array}$ & $\begin{array}{r}4.7 \\
5.1 \\
5.8 \\
6.8 \\
8.0 \\
10.6 \\
12.5 \\
14.9 \\
17.0 \\
20.7 \\
24.7 \\
30.7\end{array}$ & S-4 & $\begin{array}{l}1000 \\
5000\end{array}$ & $\begin{array}{l}0-13.2 \\
13.2+\end{array}$ & $\begin{array}{l}0.36 \\
0.36 \\
0.36 \\
0.50 \\
0.50 \\
0.50 \\
0.50 \\
0.50 \\
0.50 \\
0.50 \\
0.50 \\
0.50\end{array}$ & $\begin{array}{l}5.4 \\
5.2 \\
5.4 \\
5.6 \\
5.7 \\
6.4 \\
6.2 \\
7.1 \\
6.4 \\
7.3 \\
8.8 \\
9.3\end{array}$ & $\begin{array}{l}14.5 \\
14.2 \\
14.5 \\
16.8 \\
17.1 \\
19.2 \\
18.6 \\
21.4 \\
19.3 \\
21.8 \\
26.3 \\
28.0\end{array}$ \\
\hline
\end{tabular}


83.

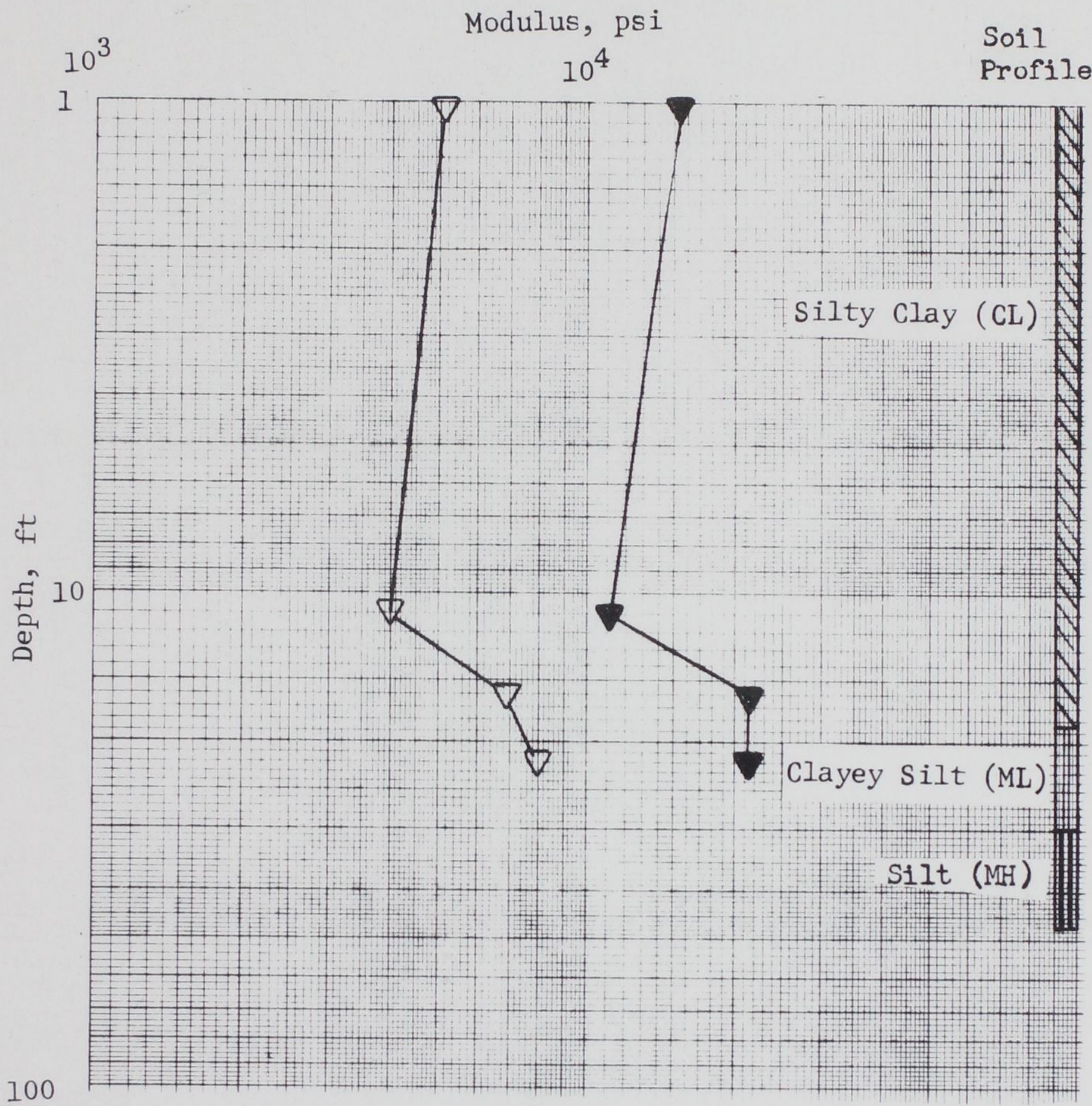

$\nabla$ Shear Modulus

- Compression

Modulus

Figure C-I. Laboratory Shear and Compression Modulus Versus Depth and Soil Profile 


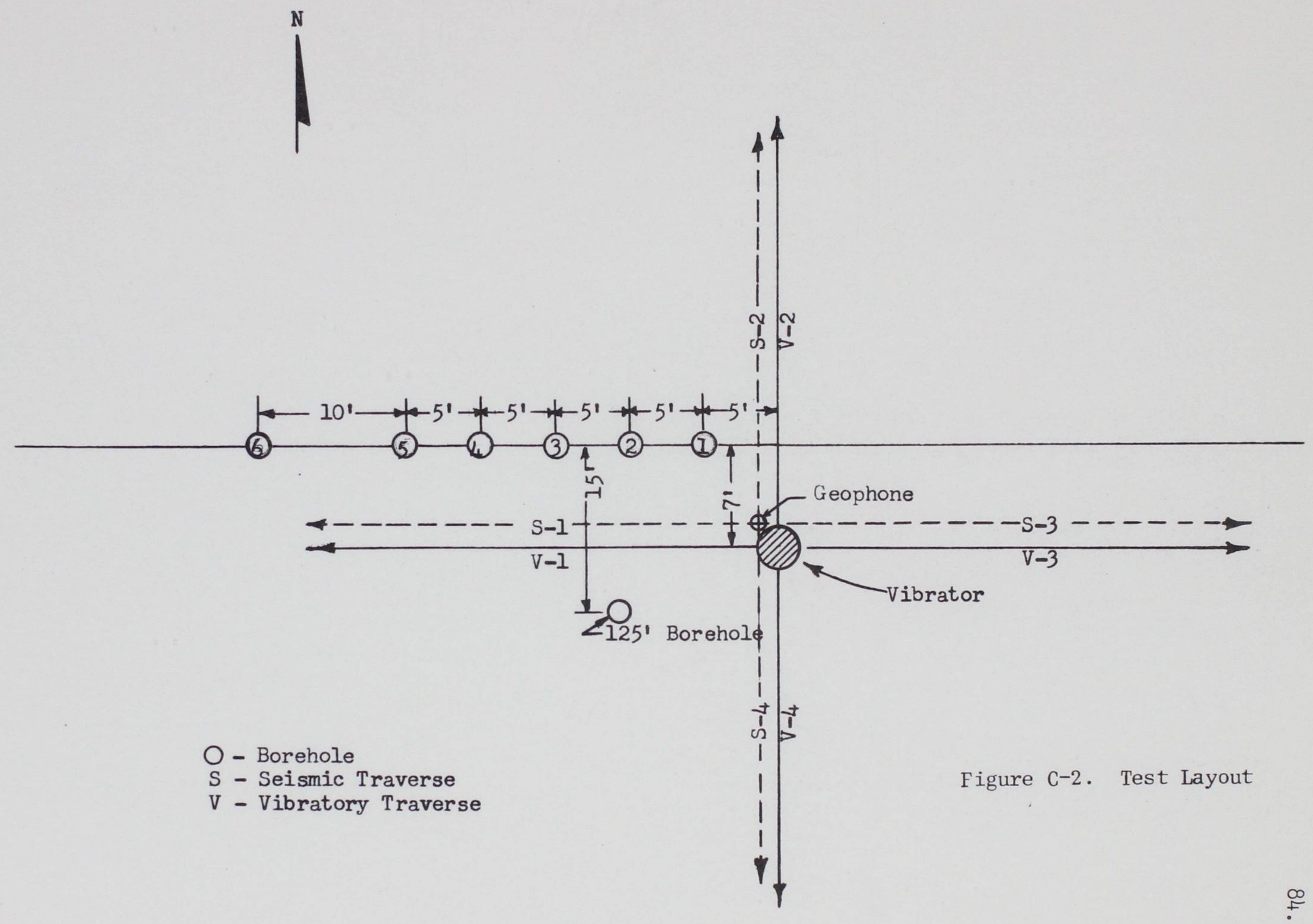




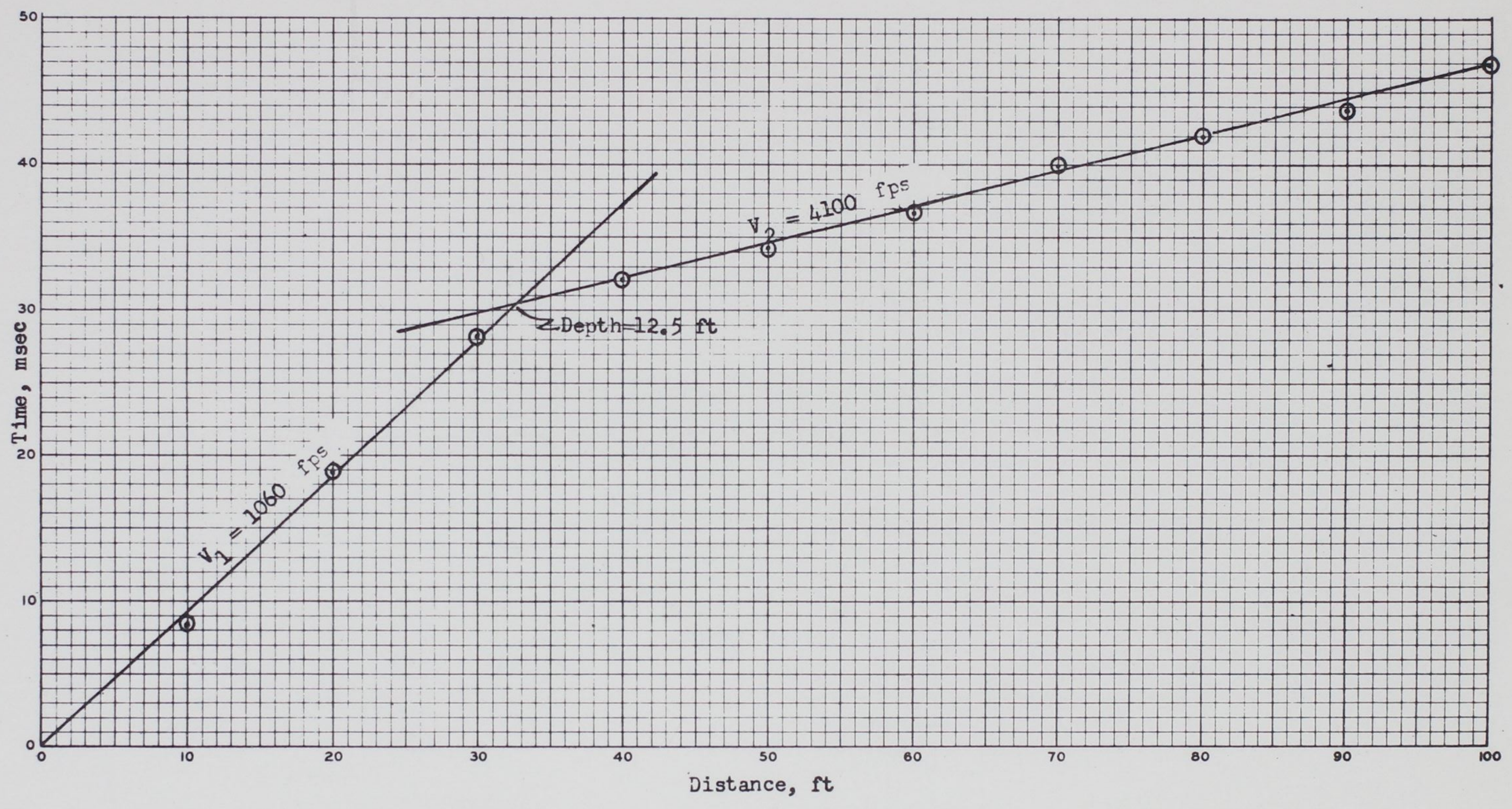

Figure C-3. Typical Refraction Seismic Traverse 


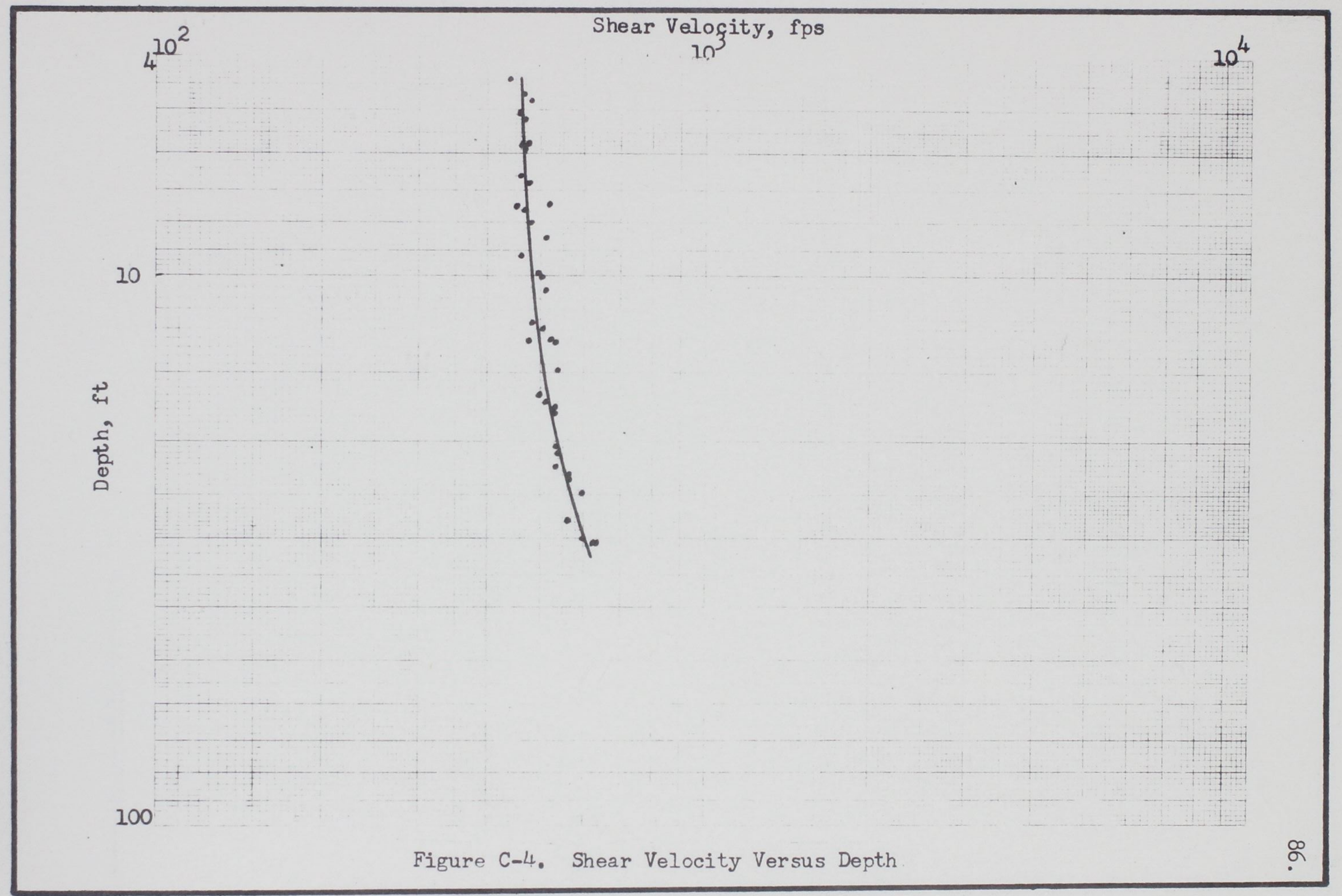




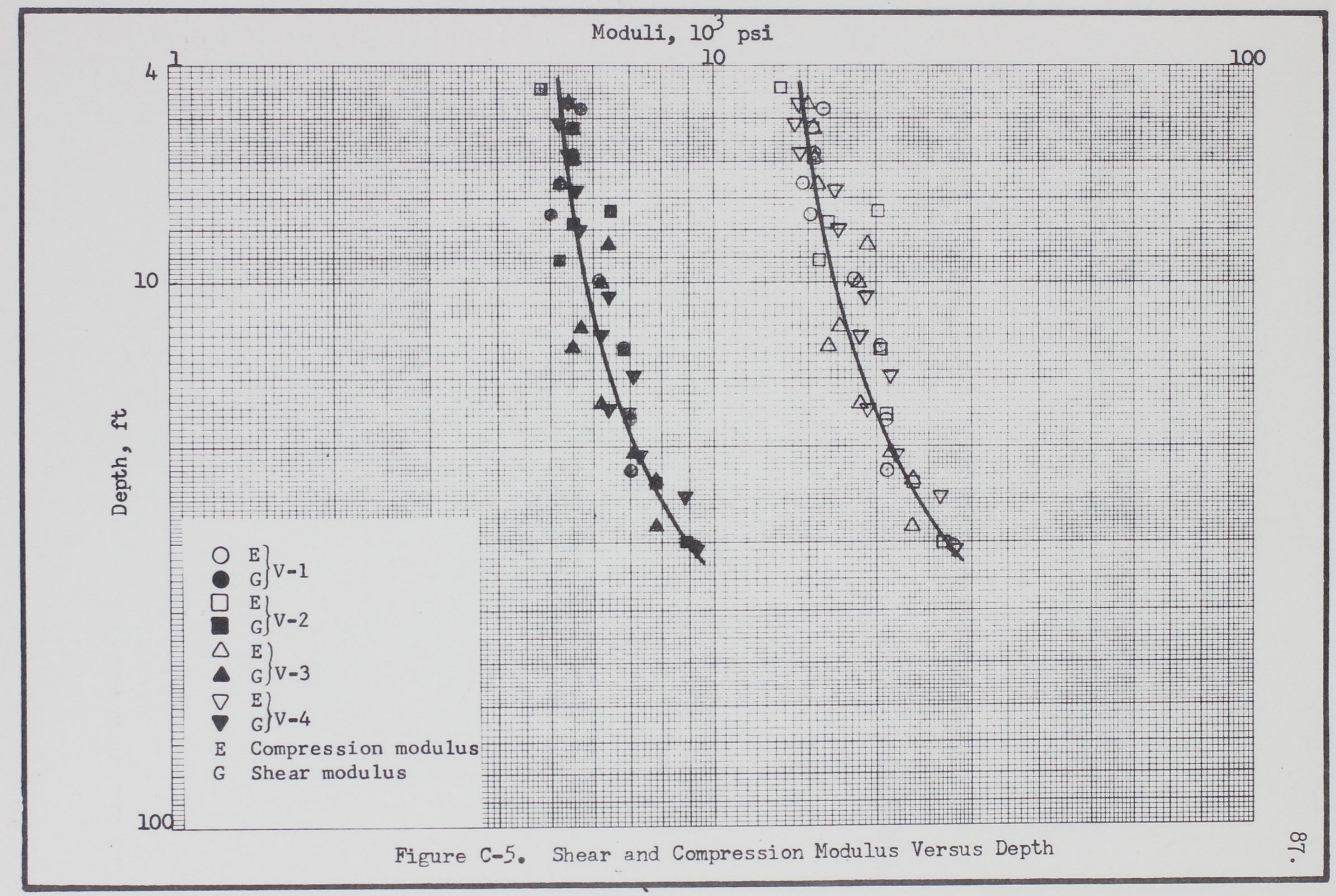


APPENDIX D

PEAK PARTICLE VELOCITY MEASUREMENTS 
Table $\mathrm{D}$-1

Group A

Surfuce Measurements of Peak Particle Velocity

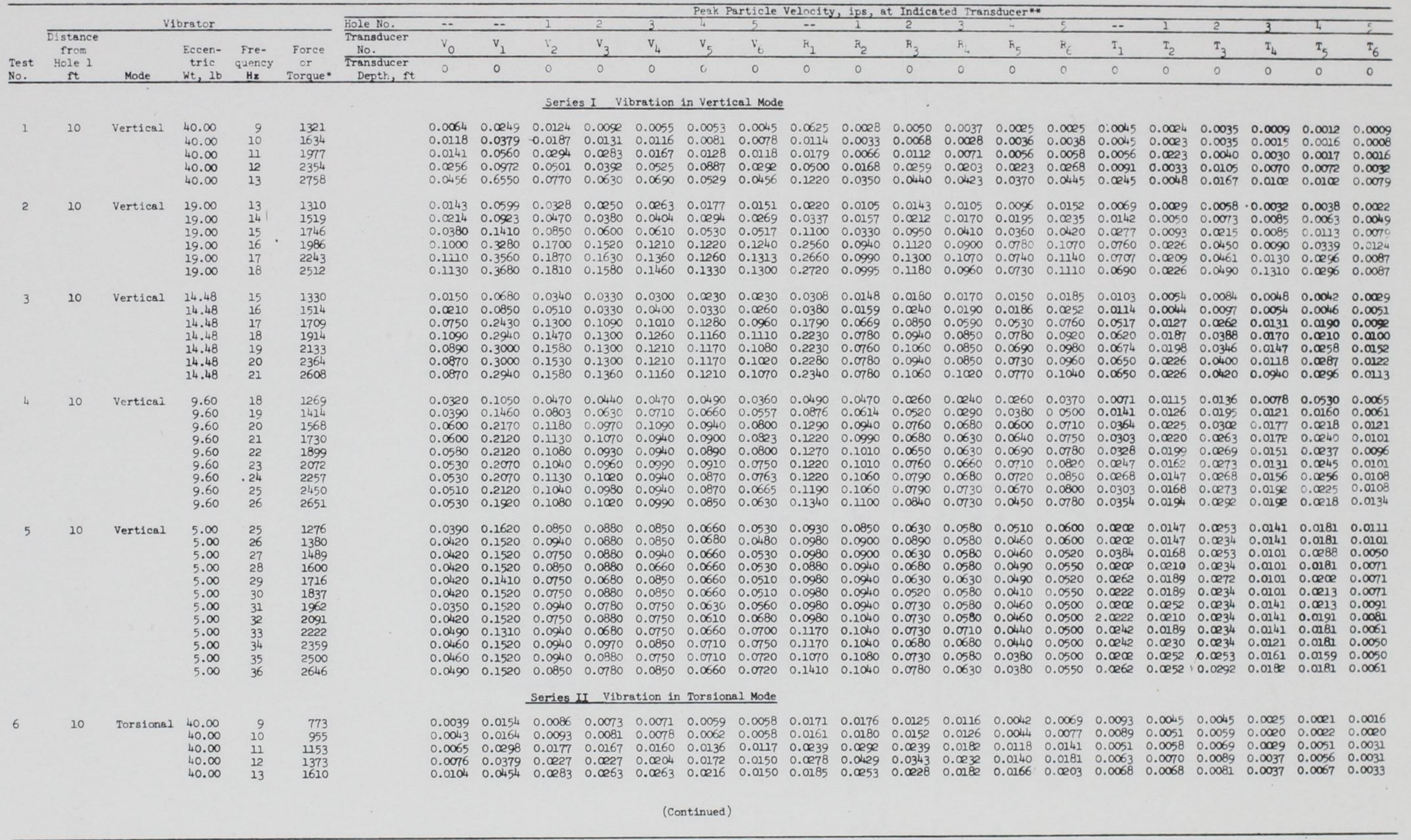

* Vertical mode - force, $1 \mathrm{~b}$; torsional mode - torque, $\mathrm{ft}-1 \mathrm{~b}$.
*.* $\mathrm{V}_{0}$ located on ground surface, $0.5 \mathrm{ft}$ from base of vibrator; $\mathrm{V}_{1}, \mathrm{R}_{1}$, and $\mathrm{T}_{1}$ located on ground surface, $5 \mathrm{ft}$ from Hole 1. 
Table $D-1$

$G$ roup $A$

Surface Measurements of Peak Particle Velocity

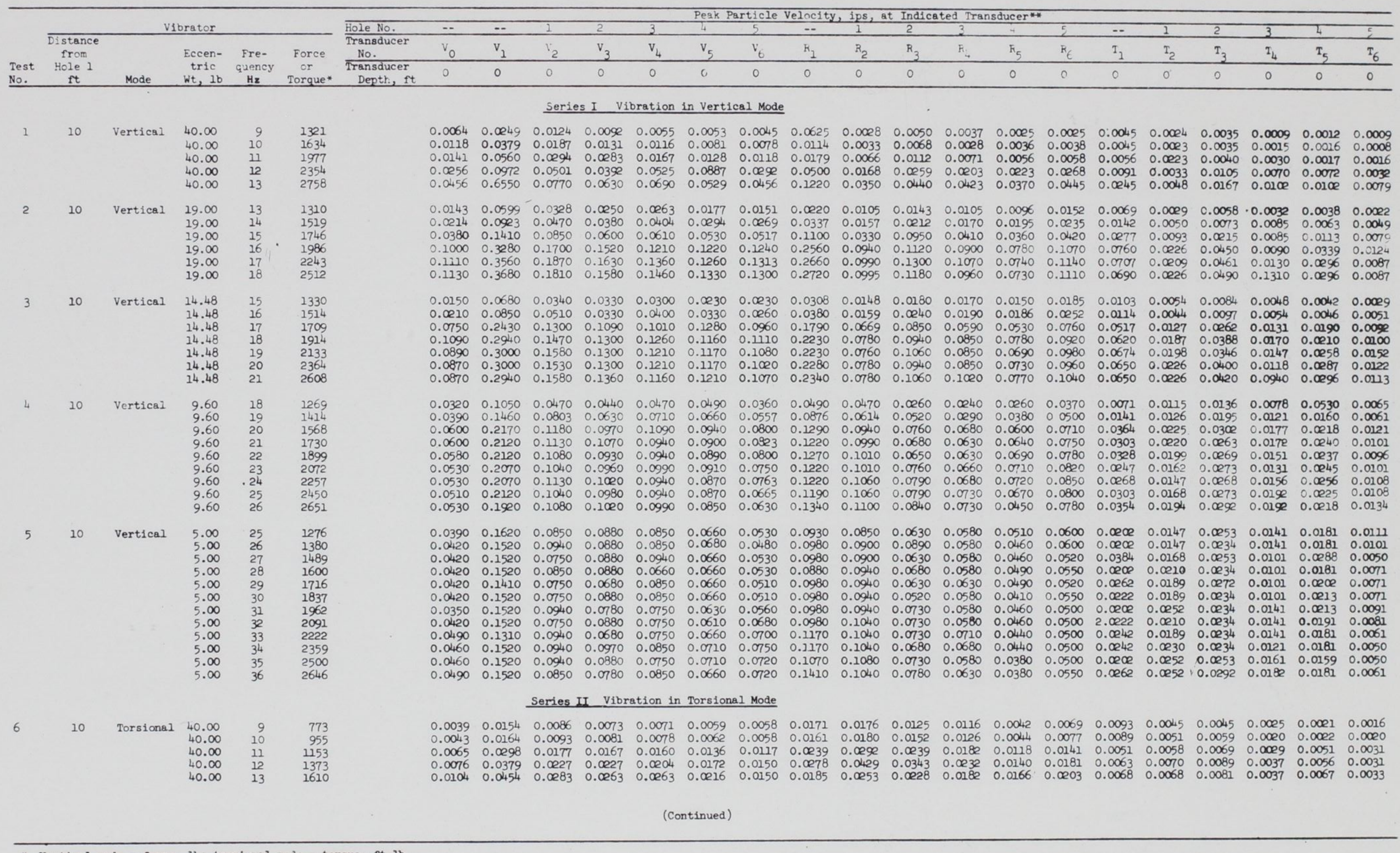

* Vertical mode - force, $1 \mathrm{~b} ;$ torsional mode - torque, ft-1b.
** $\mathrm{V}_{0}$ located on ground surface, $0.5 \mathrm{ft}$ from base of vibrator; $\mathrm{V}_{1}, \mathrm{R}_{1}$, and $\mathrm{T}_{1}$ located on ground surface, $5 \mathrm{ft}$ from Hole 1. 
Table D-1 (Concluded)

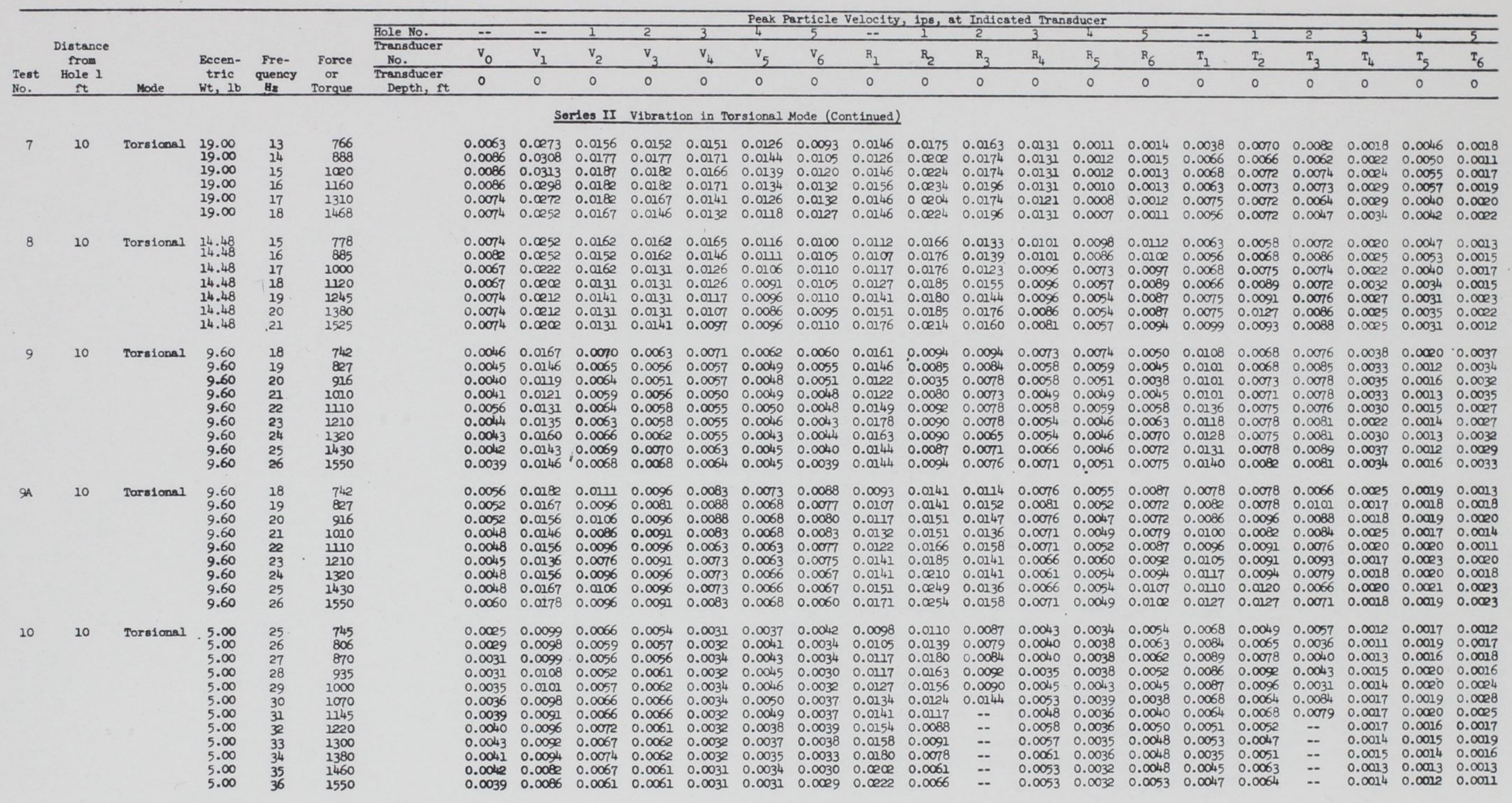


Subsurface Measurements of Peak Particle Velocity Transducers at Var1ous Depth

\begin{tabular}{|c|c|c|c|c|c|c|c|c|c|c|c|c|c|c|c|c|c|c|c|c|c|c|c|c|c|}
\hline \multirow[b]{3}{*}{ lest } & \multirow{2}{*}{\multicolumn{3}{|c|}{$\frac{\text { Vibrator }}{\text { Eccen- }}$}} & \multirow[b]{2}{*}{ Force } & \multirow{2}{*}{$\begin{array}{l}\text { Hole No. } \\
\text { Transducer } \\
\text { Not. }\end{array}$} & \multirow{2}{*}{$\ddot{v_{0}}$} & \multirow{2}{*}{$\overline{-}$} & \multirow{2}{*}{$\frac{1}{v_{0}}$} & \multirow{2}{*}{$\frac{2}{v_{3}}$} & \multirow{2}{*}{$\frac{2}{v_{4}}$} & \multicolumn{8}{|c|}{ 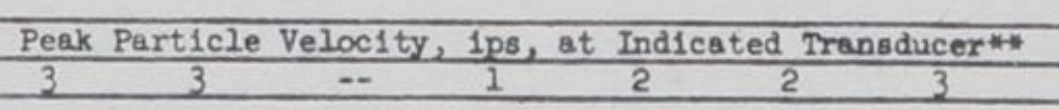 } & \multirow{2}{*}{$\frac{3}{R_{6}}$} & \multirow{2}{*}{$\ddot{T}$} & \multirow{2}{*}{$\frac{1}{T_{2}}$} & \multirow{2}{*}{$\frac{2}{T_{3}}$} & \multirow{2}{*}{$\frac{2}{T_{4}}$} & \multirow{2}{*}{$\frac{3}{T_{5}}$} & \multirow{2}{*}{$\frac{3}{T_{6}}$} \\
\hline & & & & & & & & & & & $v_{5}$ & $v_{6}$ & $R_{1}$ & $\mathrm{R}_{2}$ & $R_{3}$ & $R_{4}$ & $R_{5}$ & ${ }_{5}$ & & & & & & & \\
\hline & $\begin{array}{l}\text { Hole } 12 \\
\text { ft }\end{array}$ & Mode & $\begin{array}{l}\text { tric } \\
\text { wt, } \\
\text { wb }\end{array}$ & $\begin{array}{c}\text { or } \\
\text { Torque* }\end{array}$ & $\begin{array}{l}\text { Transsuducer } \\
\text { Depth, ft }\end{array}$ & 0 & 0 & 15 & 15 & 0 & 15 & 0 & 0 & 25 & 15 & $\circ$ & 15 & 15 & $\circ$ & 0 & 25 & 15 & $\circ$ & 15 & ${ }_{0}$ \\
\hline
\end{tabular}

Surface and at 15-1t Depth

\begin{tabular}{|c|c|c|c|c|c|c|c|c|c|c|c|c|c|c|c|c|c|c|c|c|c|c|c|c|c|}
\hline 11 & 10 & Vertícal & $\begin{array}{l}9.60 \\
9.60 \\
9.60 \\
9.60 \\
9.60 \\
9.60 \\
9.60 \\
9.60 \\
9.60 \\
9.60 \\
9.60 \\
9.60\end{array}$ & $\begin{array}{l}10 \\
12 \\
15 \\
20 \\
25 \\
30 \\
30 \\
35 \\
35 \\
40 \\
45 \\
50\end{array}$ & $\begin{array}{r}302 \\
565 \\
862 \\
1568 \\
2450 \\
3529 \\
3529 \\
4800 \\
4800 \\
6272 \\
7960 \\
9790\end{array}$ & & $\begin{array}{l}0.0097 \\
0.0168 \\
0.0093 \\
0.0336 \\
0.0800 \\
0.0752 \\
0.0787 \\
0.0800 \\
0.0950 \\
0.0967 \\
0.1090 \\
0.1590\end{array}$ & $\begin{array}{l}0.0152 \\
0.030 \\
0.0195 \\
0.0760 \\
0.1440 \\
0.1240 \\
0.1270 \\
0.17270 \\
0.140 \\
0.1400 \\
0.1460 \\
0.2270\end{array}$ & $\begin{array}{l}0.0107 \\
0.0185 \\
0.0117 \\
0.030 \\
0.0477 \\
0.0312 \\
0.0321 \\
0.0224 \\
0.0243 \\
0.0117 \\
0.0146 \\
0.0497\end{array}$ & $\begin{array}{l}0.0078 \\
0.0146 \\
0.0078 \\
0.0243 \\
0.0418 \\
0.0311 \\
0.0321 \\
0.0292 \\
0.0341 \\
0.0360 \\
0.0428 \\
0.0720\end{array}$ & $\begin{array}{l}0.0132 \\
0.0341 \\
0.014 \\
0.0149 \\
0.0968 \\
0.1140 \\
0.1440 \\
0.1360 \\
0.1540 \\
0.1510 \\
0.1580 \\
0.1800 \\
0.2140\end{array}$ & $\begin{array}{l}0.0066 \\
0.0133 \\
0.0078 \\
0.0205 \\
0.02079 \\
0.0238 \\
0.0446 \\
0.0287 \\
0.0320 \\
0.0435 \\
0.0492 \\
0.0565\end{array}$ & $\begin{array}{l}0.0110 \\
0.0256 \\
0.0172 \\
0.0697 \\
0.1360 \\
0.1340 \\
0.1360 \\
0.1330 \\
0.1290 \\
0.1360 \\
0.1210 \\
0.1730\end{array}$ & $\begin{array}{l}0.0051 \\
0.0448 \\
0.0122 \\
0.0620 \\
0.1500 \\
0.2150 \\
0.1890 \\
0.27110 \\
0.2040 \\
0.1410 \\
0.2750 \\
0.22260\end{array}$ & 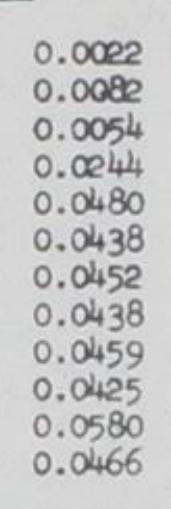 & $\begin{array}{c}0.0056 \\
\because \\
\because \\
\because \\
\because \\
\because \\
\because \\
\because\end{array}$ & $\begin{array}{l}0.0036 \\
0.0190 \\
0.0908 \\
0.070 \\
0.2120 \\
0.1610 \\
0.190 \\
0.1905 \\
0.1450 \\
0.0456 \\
0.0488 \\
0.0365\end{array}$ & 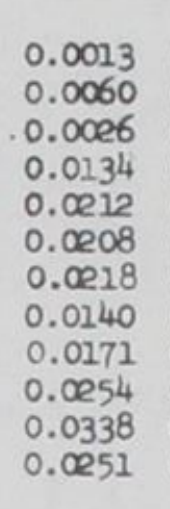 & 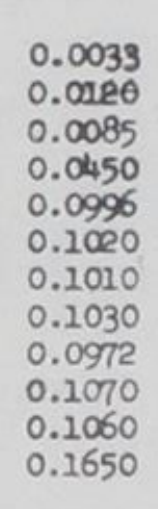 & 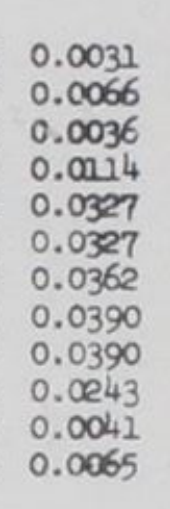 & 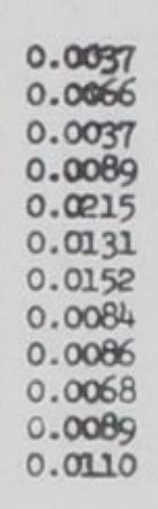 & 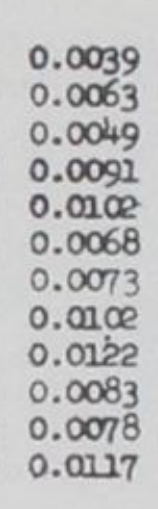 & 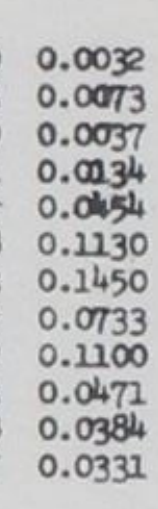 & 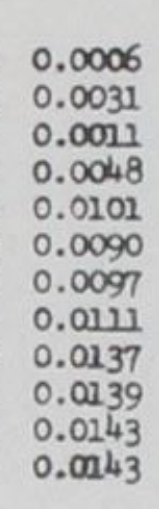 & 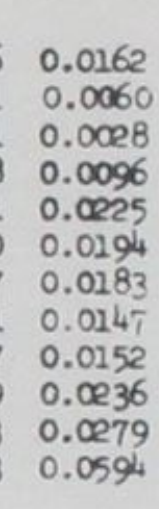 \\
\hline 12 & 10 & Tora1onal & $\begin{array}{l}9.60 \\
9.60 \\
9.60 \\
9.60 \\
9.60 \\
9.60 \\
9.60 \\
9.60 \\
9.60 \\
9.60\end{array}$ & $\begin{array}{l}10 \\
12 \\
15 \\
20 \\
25 \\
30 \\
35 \\
40 \\
45 \\
50\end{array}$ & $\begin{array}{r}228 \\
330 \\
515 \\
916 \\
1430 \\
2060 \\
2810 \\
3670 \\
4650 \\
5720\end{array}$ & & $\begin{array}{l}0.0038 \\
0.00060 \\
0.0048 \\
0.0044 \\
0.00040 \\
0.0059 \\
0.0048 \\
0.0052 \\
0.00086 \\
0.0108\end{array}$ & $\begin{array}{l}0.0100 \\
0.0114 \\
0.0110 \\
0.0100 \\
0.0078 \\
0.0100 \\
0.0100 \\
0.0078 \\
0.0110 \\
0.0105\end{array}$ & $\begin{array}{l}0.0037 \\
0.0068 \\
0.00031 \\
0.0002 \\
0.0017 \\
0.0056 \\
0.0063 \\
0.0007 \\
0.0109 \\
0.0083\end{array}$ & $\begin{array}{l}0.0028 \\
0.0043 \\
0.0016 \\
0.0015 \\
0.0023 \\
0.0033 \\
0.0042 \\
0.0034 \\
0.0062 \\
0.0152\end{array}$ & $\begin{array}{l}0.0101 \\
0.002 \\
0.0116 \\
0.0096 \\
0.0111 \\
0.0111 \\
0.0006 \\
0.0076 \\
0.00066 \\
0.0078\end{array}$ & $\begin{array}{l}0.0024 \\
0.0009 \\
0.0015 \\
0.0000 \\
0.0004 \\
0.00626 \\
0.0035 \\
0.0055 \\
0.0090 \\
0.0153\end{array}$ & $\begin{array}{l}0.0078 \\
0.0178 \\
0.0100 \\
0.00076 \\
0.0056 \\
0.0078 \\
0.0081 \\
0.0071 \\
0.00666 \\
0.0066\end{array}$ & $\begin{array}{l}0.0088 \\
0.0115 \\
0.0126 \\
0.0177 \\
0.0146 \\
0.0263 \\
0.0126 \\
0.0209 \\
0.00068 \\
0.0068\end{array}$ & 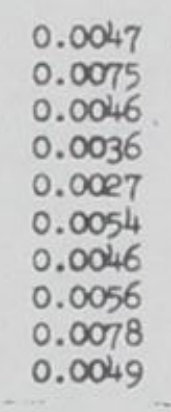 & $\begin{array}{c}0.0049 \\
0.0089 \\
-\because \\
\because- \\
\because- \\
\because \\
-\end{array}$ & 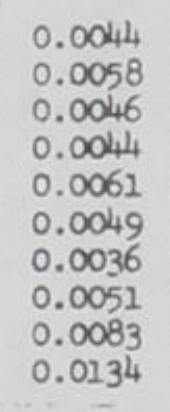 & $\begin{array}{l}0.0029 \\
0.0065 \\
0.0068 \\
0.0016 \\
0.00023 \\
0.0038 \\
0.0028 \\
0.0031 \\
0.0031 \\
0.0447 \\
0.0057\end{array}$ & $\begin{array}{l}0.0110 \\
0.0161 \\
0.0105 \\
0.0083 \\
0.0076 \\
0.0100 \\
0.0080 \\
0.064 \\
0.0054 \\
0.0557\end{array}$ & 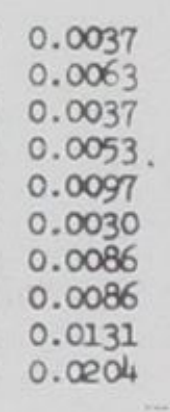 & $\begin{array}{l}0.0033 \\
0.033 \\
0.0033 \\
0.0038 \\
0.036 \\
0.0032 \\
0.0042 \\
0.0061 \\
0.0098 \\
0.0058\end{array}$ & 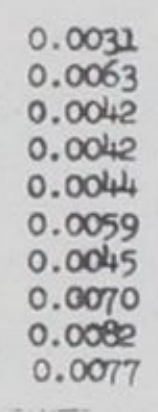 & $\begin{array}{l}0.0101 \\
0.0178 \\
0.013131 \\
0.0147 \\
0.0288 \\
0.00084 \\
0.0058 \\
0.0037 \\
0.0047 \\
0.0120\end{array}$ & $\begin{array}{l}z \\
\ddot{z} \\
\ddot{z} \\
\ddot{z} \\
0.0000 \\
0.000 \\
0.0000\end{array}$ & $\begin{array}{l}0.0032 \\
0.0029 \\
0.0011 \\
0.0013 \\
0.0009 \\
0.0038 \\
0.0038 \\
0.0028 \\
0.0035 \\
0.0044\end{array}$ \\
\hline \multirow{2}{*}{\multicolumn{6}{|c|}{ vibrator }} & & $\ldots$ & - & 1 & 2 & 2 & 3 & 3 & $\because$ & $\frac{2 \mathrm{pgs},}{1}$ & $\frac{t \text { Indicate }}{2}$ & $\frac{\operatorname{ted} 7 x}{2}$ & & 3 & - & 1 & 2 & 2 & 3 & 3 \\
\hline & & & & & & & $\mathrm{v}_{0}$ & $v_{1}$ & $v_{2}$ & $v_{3}$ & $v_{4}$ & $v_{5}$ & $v_{6}$ & $\mathrm{R}_{1}$ & $R_{2}$ & $\mathrm{R}_{3}$ & $R_{4}$ & $\mathrm{R}_{5}$ & $\mathrm{R}_{6}$ & $T_{1}$ & $T_{2}$ & $T_{3}$ & $T_{4}$ & $T_{5}$ & $T_{6}$ \\
\hline & & & & & T & & 0 & 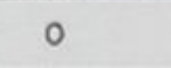 & 15 & 15 & 15 & 15 & 15 & 0 & 15 & 25 & 25 & 19 & 15 & & 15 & 15 & 15 & 15 & 15 \\
\hline
\end{tabular}

Series IV Major Transducers on Surface and at 15-ft Depth

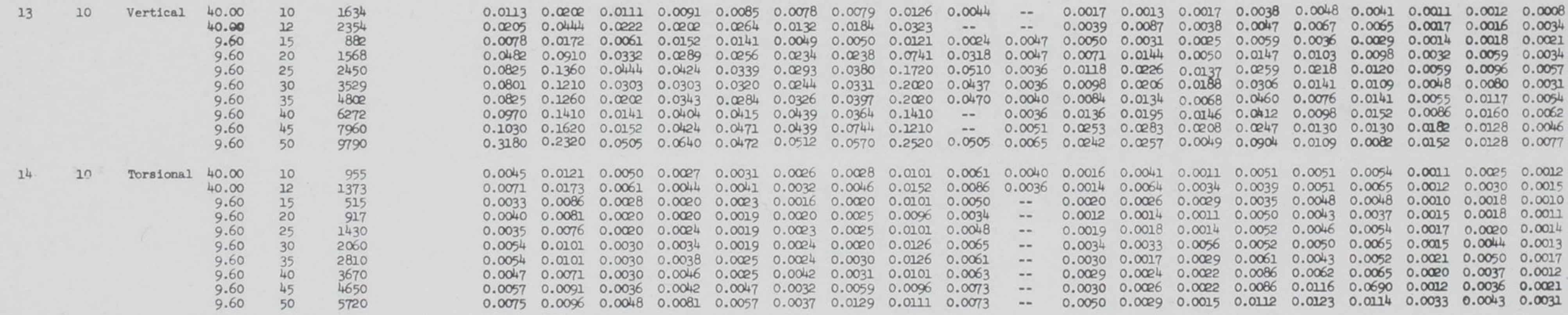


Table D-2 (Continued)

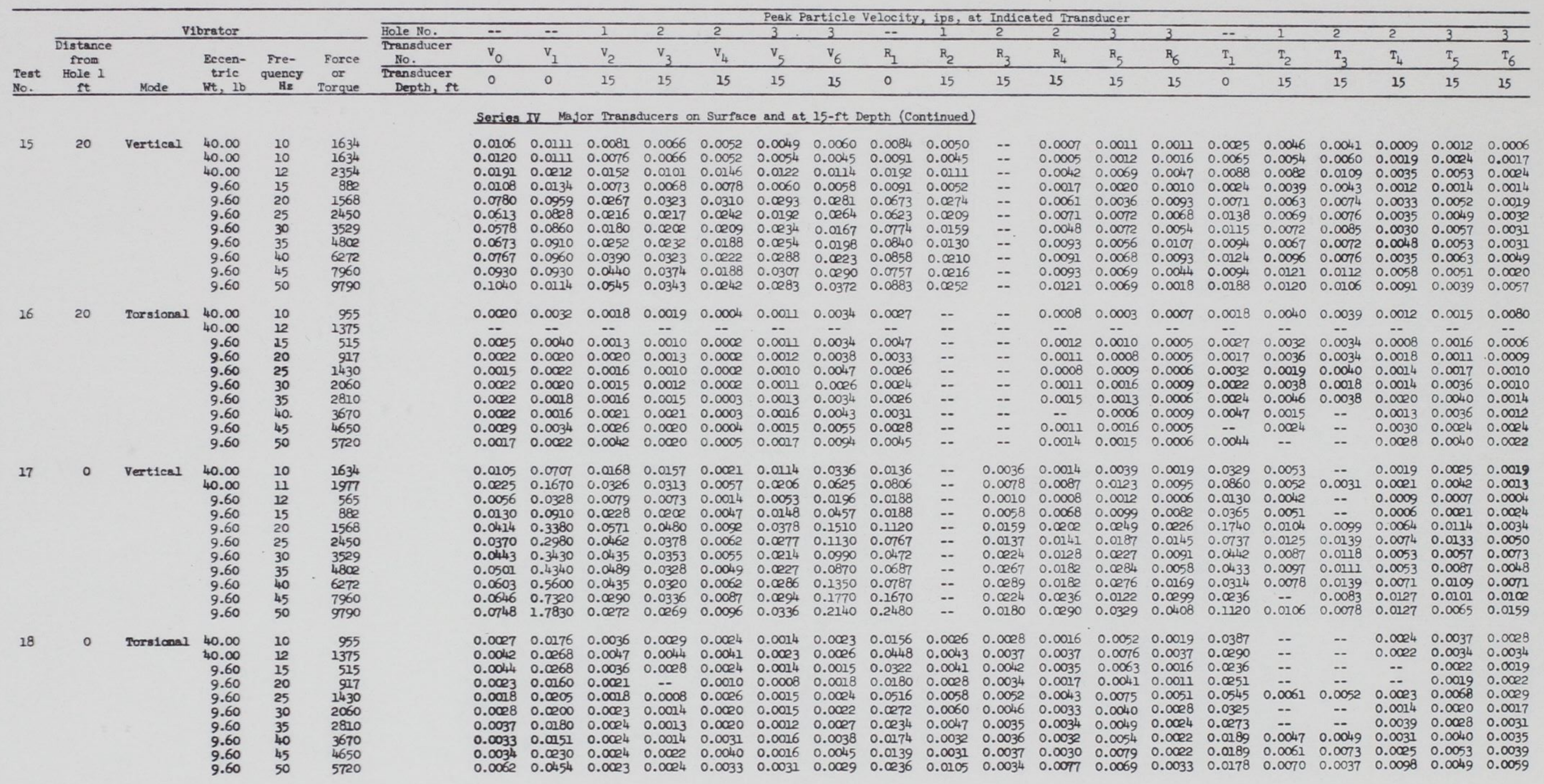


Table D-2 (Continued)

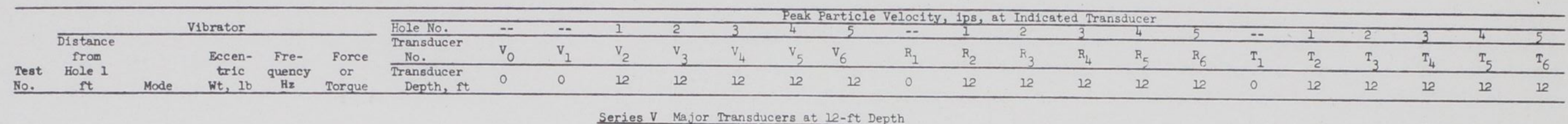

Series $V$ Major Transducers at 12 -ft Depth

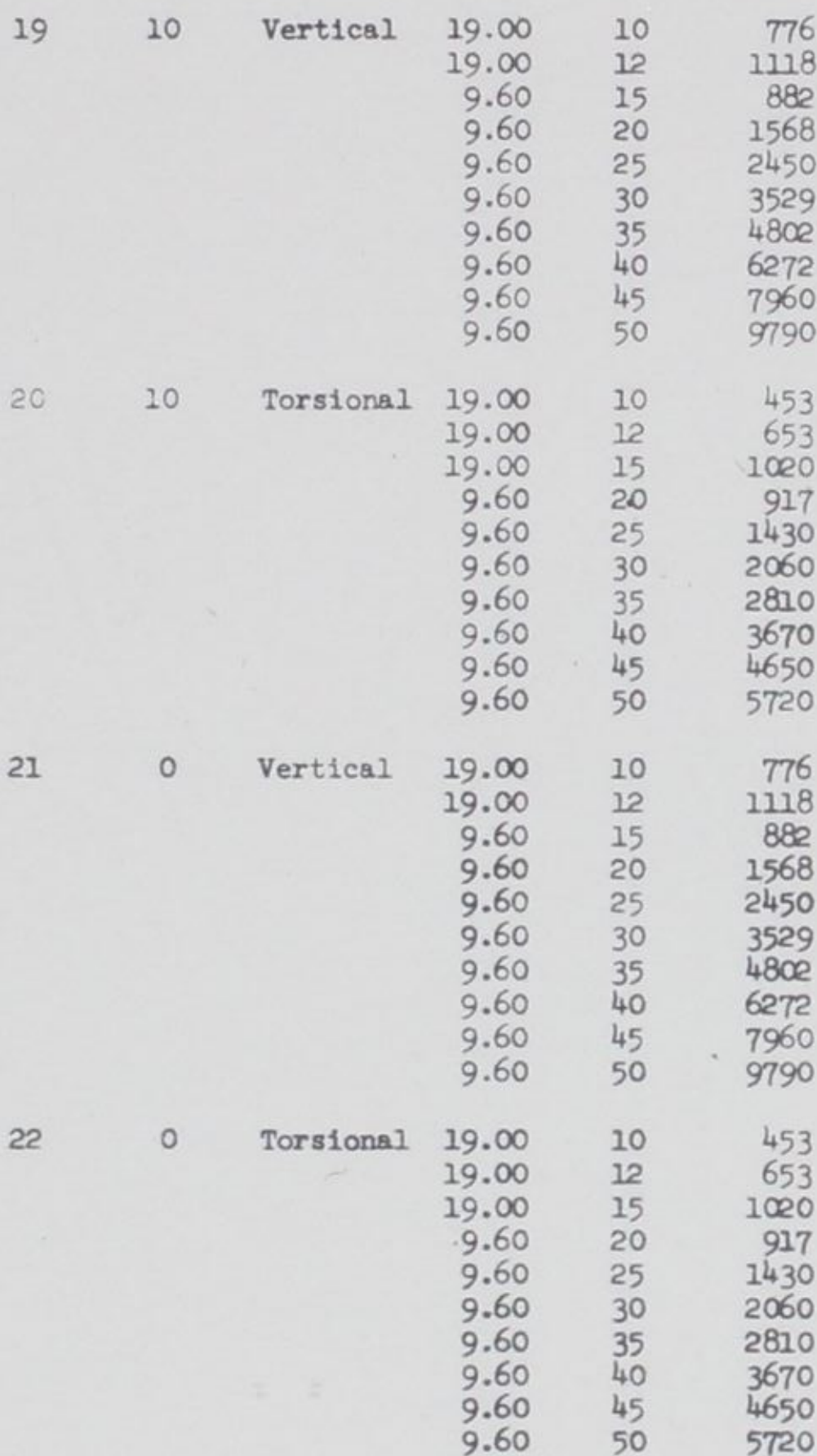

$\begin{array}{lllllllllllllllllll}0.2660 & 0.0058 & 0.0047 & 0.0038 & 0.0024 & 0.0027 & 0.0028 & 0.0026 & 0.0042 & 0.0065 & 0.0028 & 0.0005 & 0.0005 & 0.0080 & 0.0032 & 0.0002 & 0.0008 & 0.0014 & 0.0007 \\ 0.6900 & 0.0153 & 0.0099 & 0.0086 & 0.0094 & 0.0083 & 0.0102 & 0.0154 & 0.0050 & 0.0056 & 0.0024 & 0.0016 & 0.0006 & 0.0118 & 0.0063 & 0.00044 & 0.0008 & 0.0035 & 0.0008\end{array}$

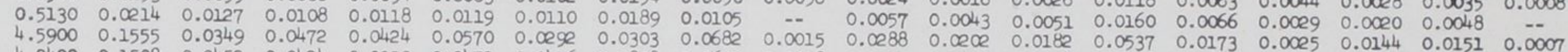

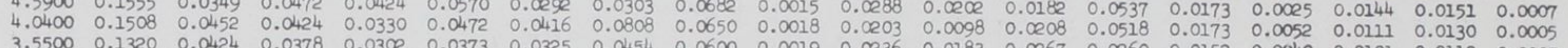

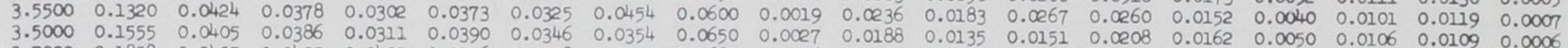

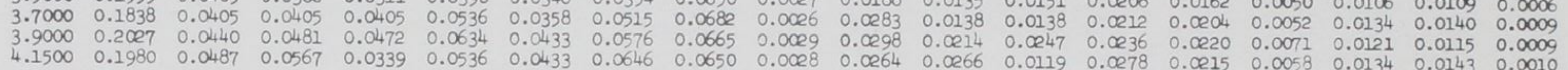
$\begin{array}{lllllllllllllllllllll}2.6300 & 0.0070 & 0.0026 & 0.0021 & 0.0024 & 0.0024 & 0.0025 & 0.0149 & 0.0059 & -- & 0.0014 & 0.0009 & 0.0010 & 0.0113 & - & - & - & 0.0018 & 0.0022 & --\end{array}$

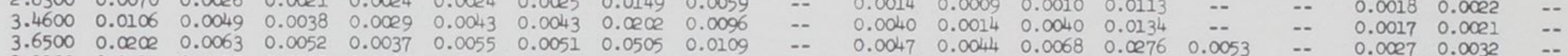

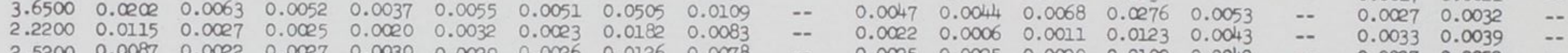
$\begin{array}{lllllllllllllllllll}2.5200 & 0.0007 & 0.0022 & 0.0027 & 0.0030 & 0.0029 & 0.0026 & 0.0126 & 0.0078 & - & 0.0025 & 0.0025 & 0.0020 & 0.0109 & 0.0042 & -- & 0.00027 & 0.0052 & - \\ 2.6200 & 0.0125 & 0.0054 & 0.0039 & 0.0036 & 0.0005 & 0.0016 & 0.0346 & 0.0073 & -. & 0.0047 & 0.0050 & 0.0037 & 0.0241 & 0.0063 & -- & 0.0037 & 0.0054 & --\end{array}$

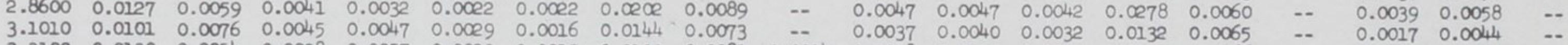

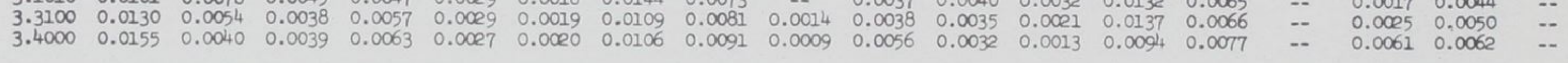
$\begin{array}{llllllllllllllllllll}0.5910 & 0.0472 & 0.0083 & 0.0092 & 0.0083 & 0.0067 & 0.0075 & 0.0208 & 0.0059 & -- & 0.0020 & 0.0014 & 0.0017 & 0.0142 & 0.0052 & 0.0104 & 0.0014 & 0.0017 & - \\ 0.8380 & 0.0975 & 0.0219 & 0.0187 & 0.0165 & 0.0150 & 0.0143 & 0.0758 & 0.0061 & -- & 0.0080 & 0.0083 & 0.0056 & 0.0189 & 0.0067 & - & 0.0015 & 0.0021 & --\end{array}$

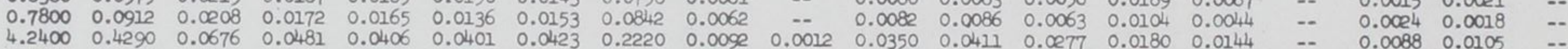

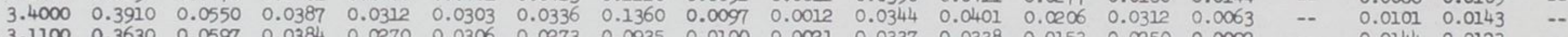

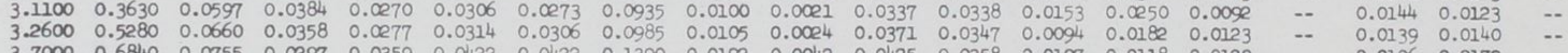

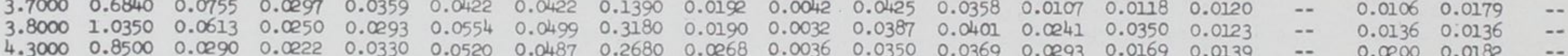
4.

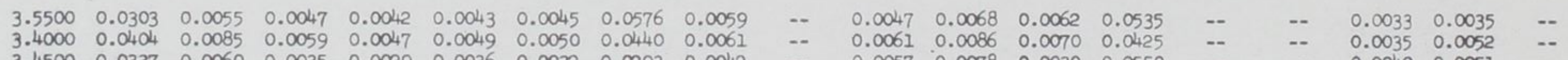

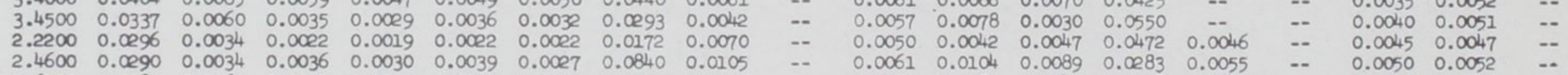

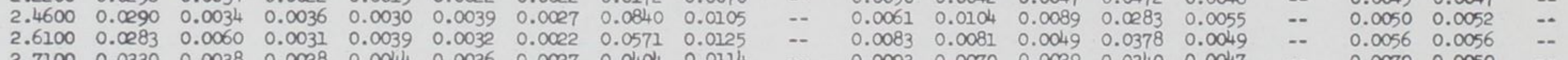

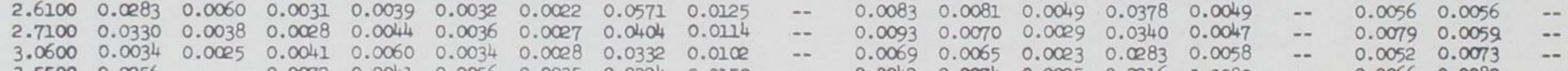

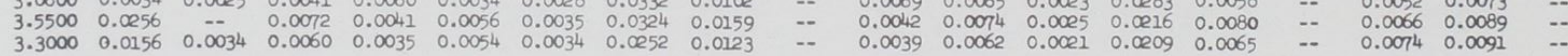


Table D-2 (Continued)

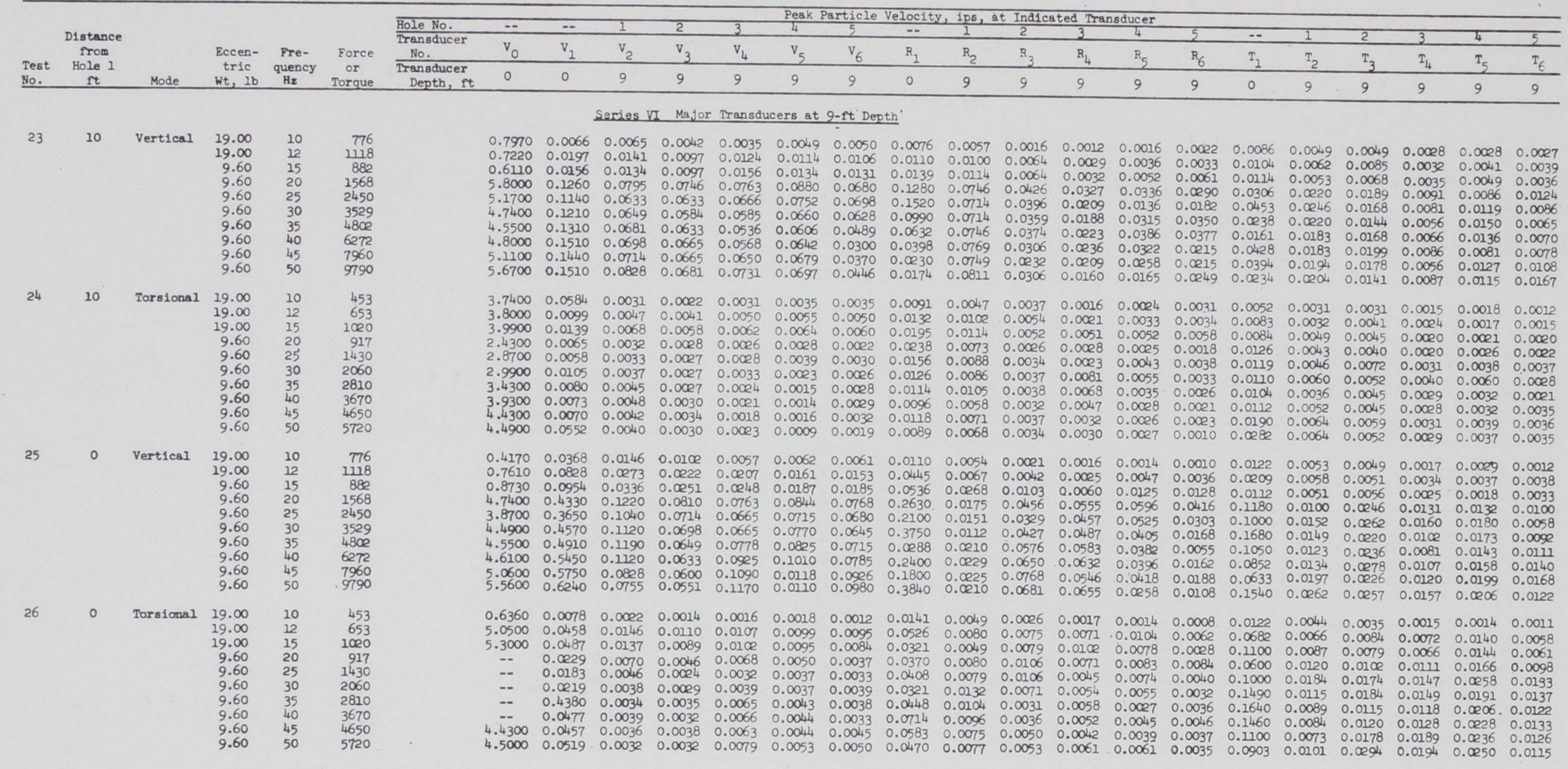


Table D-2 (Continued)

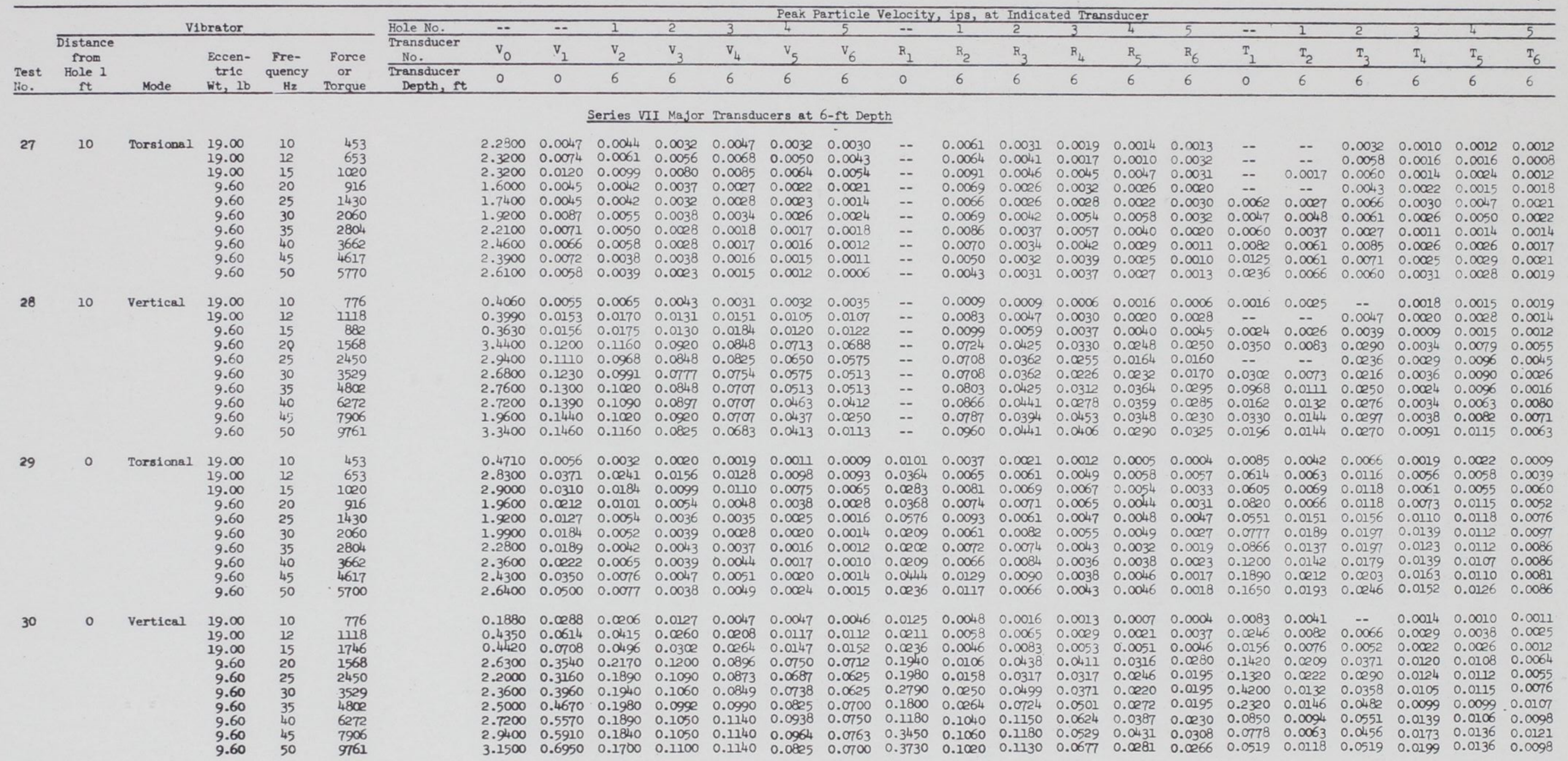


Table D-2 (Concluded)

\begin{tabular}{|c|c|c|c|c|c|c|c|c|c|c|c|c|c|c|c|c|c|c|c|c|c|c|c|c|c|}
\hline & & & orator & & & Hole №. & -- & $\cdots$ & 1 & 2 & 3 & $\frac{\text { Peas }}{4}$ & $\frac{\frac{c 12 c 1}{5}}{5}$ & $\frac{100}{-1}$ & $\frac{\frac{1 p s}{1}}{1}$ & $\frac{\ln a}{2}$ & $\frac{219}{3}$ & $\frac{u \text { uncer }}{4}$ & 5 & $\ldots$ & 1 & 2 & 3 & 4 & 5 \\
\hline & $\begin{array}{l}\text { Distance } \\
\text { from }\end{array}$ & & Eecen- & Fre- & Force & $\begin{array}{l}\text { Transducer } \\
\text { No. }\end{array}$ & $v_{0}$ & $\mathrm{v}_{1}$ & $\mathrm{v}_{2}$ & $\mathrm{v}$ & $v_{4}$ & $\mathrm{v}_{5}$ & $\mathrm{v}_{6}$ & $\mathrm{R}_{1}$ & $\mathrm{R}_{2}$ & $\mathrm{R}_{3}$ & $\mathrm{R}_{4}$ & $\mathrm{R}_{5}$ & $\mathrm{R}_{6}$ & $\mathrm{~T}_{1}$ & $\mathrm{~T}_{2}$ & $\mathrm{~T}_{3}$ & $\mathrm{~T}_{4}$ & $\mathrm{~T}_{5}$ & $\mathrm{I}_{6}$ \\
\hline $\begin{array}{l}\text { Test } \\
\text { loo. }\end{array}$ & $\begin{array}{l}\text { Hole } 1 \\
\mathrm{ft}\end{array}$ & Mode & $\begin{array}{l}\text { tric } \\
\text { wt, } 1 \mathrm{~b}\end{array}$ & 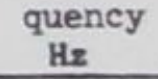 & $\begin{array}{l}\text { or } \\
\text { Torque }\end{array}$ & $\begin{array}{l}\text { Transiducer } \\
\text { Depth, ft }\end{array}$ & $\circ$ & 0 & 3 & 3 & 3 & 3 & 3 & 0 & 3 & 3 & 3 & 3 & 3 & 0 & 3 & 3 & 3 & 3 & 3 \\
\hline
\end{tabular}

Series VIII Major Transducers at 3-ft Depth

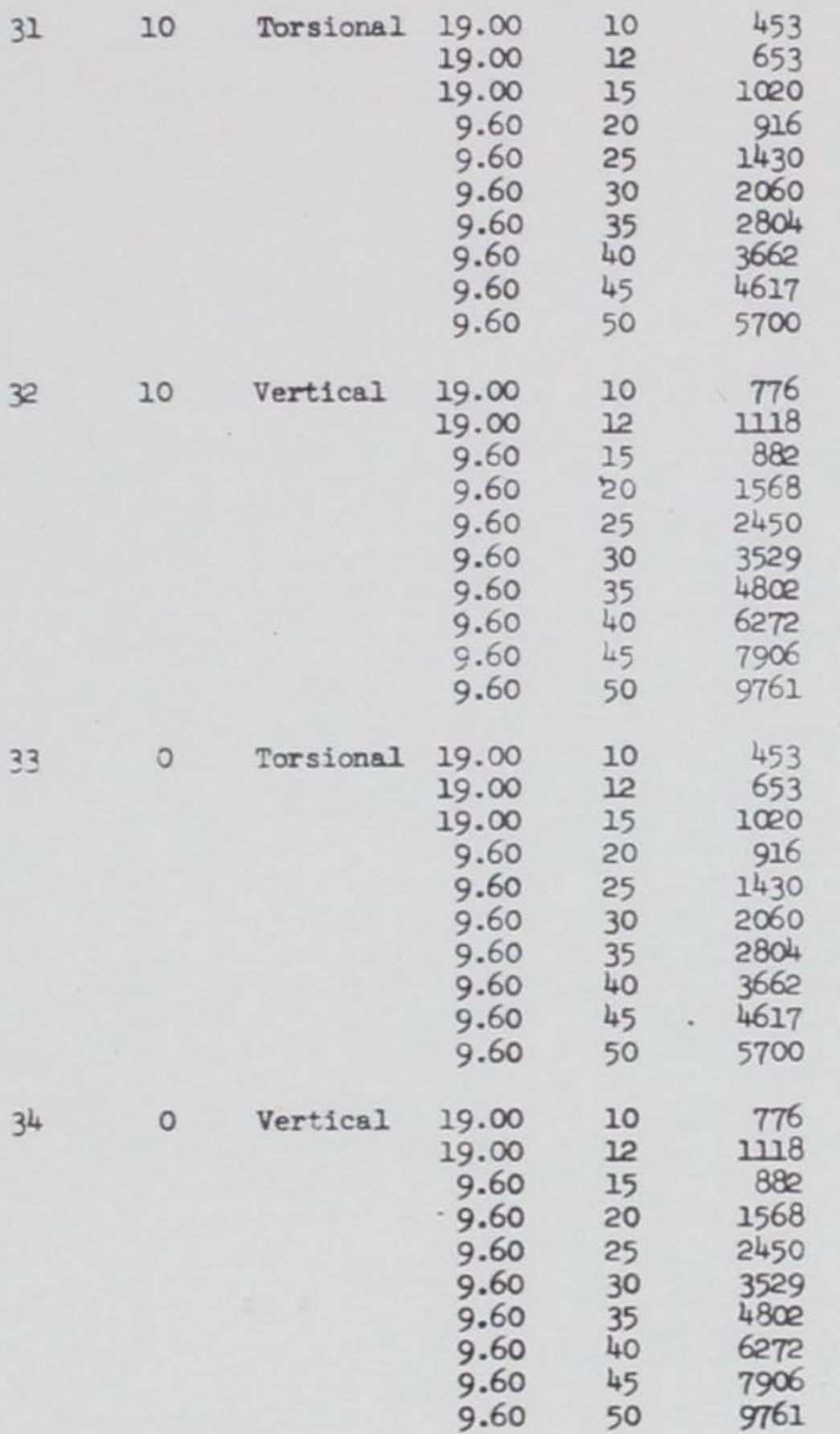

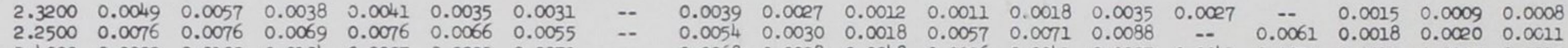

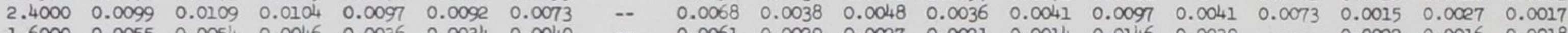
$\begin{array}{lllllllllllllllllllll}1.6000 & 0.0052 & 0.0052 & 0.0039 & 0.0033 & 0.0039 & 0.0038 & -- & 0.0061 & 0.0036 & 0.0021 & 0.0013 & 0.0015 & 0.0134 & 0.0071 & 0.0080 & 0.0030 & 0.0040 & 0.0027\end{array}$

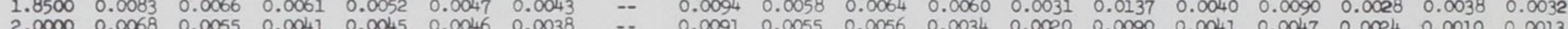

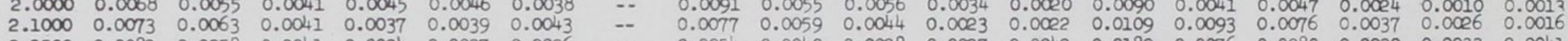

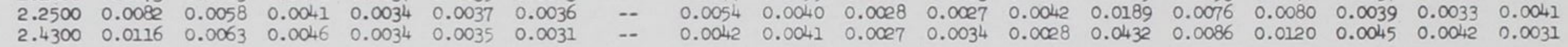

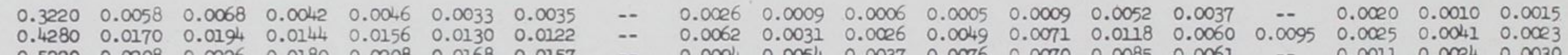

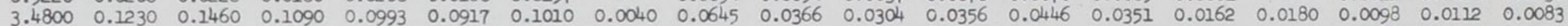

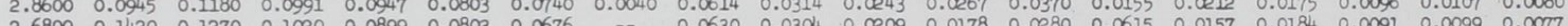

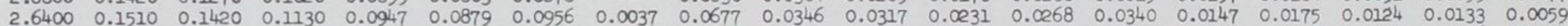

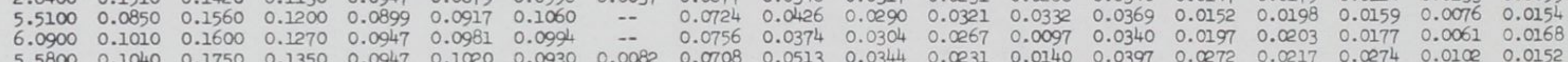
$\begin{array}{llllllllllllllllllll}0.6810 & 0.0120 & 0.0118 & 0.0063 & 0.0045 & 0.0034 & 0.0033 & 0.0158 & 0.0027 & 0.0034 & - & 0.0012 & 0.0010 & 0.0270 & - & 0.0054 & 0.0029 & 0.0022 & 0.0013\end{array}$

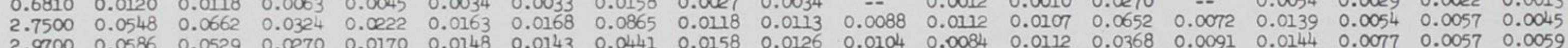
$\begin{array}{llllllllllllllllllll}1.9200 & 0.0358 & 0.3260 & 0.0165 & 0.0099 & 0.0089 & 0.0080 & 0.0170 & 0.0064 & 0.0101 & 0.0079 & 0.0038 & 0.0053 & 0.0538 & 0.009 & 0.0087 & 0.0066 & 0.0071 & 0.0048\end{array}$ $\begin{array}{llllllllllllllllllll}1.9600 & 0.0501 & 0.0198 & 0.0113 & 0.0061 & 0.0051 & 0.0042 & 0.0349 & 0.0076 & 0.0124 & 0.0063 & 0.0056 & 0.0038 & 0.0598 & 0.0154 & 0.0222 & 0.0108 & 0.0079 & 0.0055\end{array}$

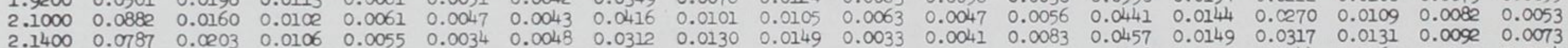

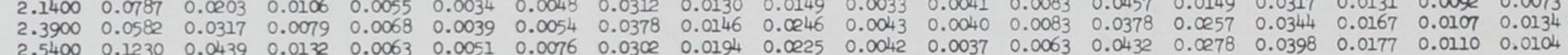
$\begin{array}{lllllllllllllllllll}0.2420 & 0.0307 & 0.0354 & 0.0156 & 0.0090 & 0.0058 & 0.0058 & - & 0.0022 & 0.0019 & - & 0.0009 & - & 0.0109 & 0.0025 & 0.0047 & 0.0017 & 0.0015 & 0.0014\end{array}$ $\begin{array}{lllllllllllllllllll}0.5250 & 0.0779 & 0.0445 & 0.0416 & 0.0255 & 0.0203 & 0.0203 & 0.0590 & 0.0104 & 0.0116 & 0.0054 & 0.0094 & 0.0071 & 0.0425 & -. & 0.0111 & 0.0047 & 0.0038 & 0.0024\end{array}$

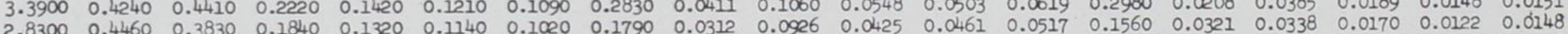
$\begin{array}{llllllllllllllllllll}2.8700 & 0.4830 & 0.3910 & 0.2030 & 0.1230 & 0.1320 & 0.1090 & 0.1090 & 0.0255 & 0.1040 & 0.0472 & 0.0503 & 0.0598 & 0.0755 & 0.0350 & 0.0392 & 0.0165 & 0.0172 & 0.0138\end{array}$

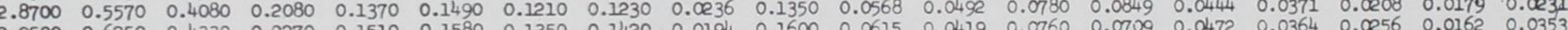

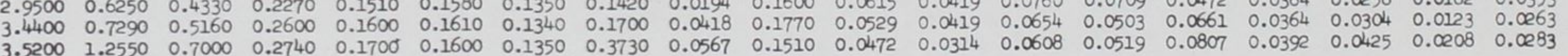


Table $D-3$

Group C

Subsurface Measurements of Peak Particle Velocity, Major Transducer: at Various Deptis in Hole 1

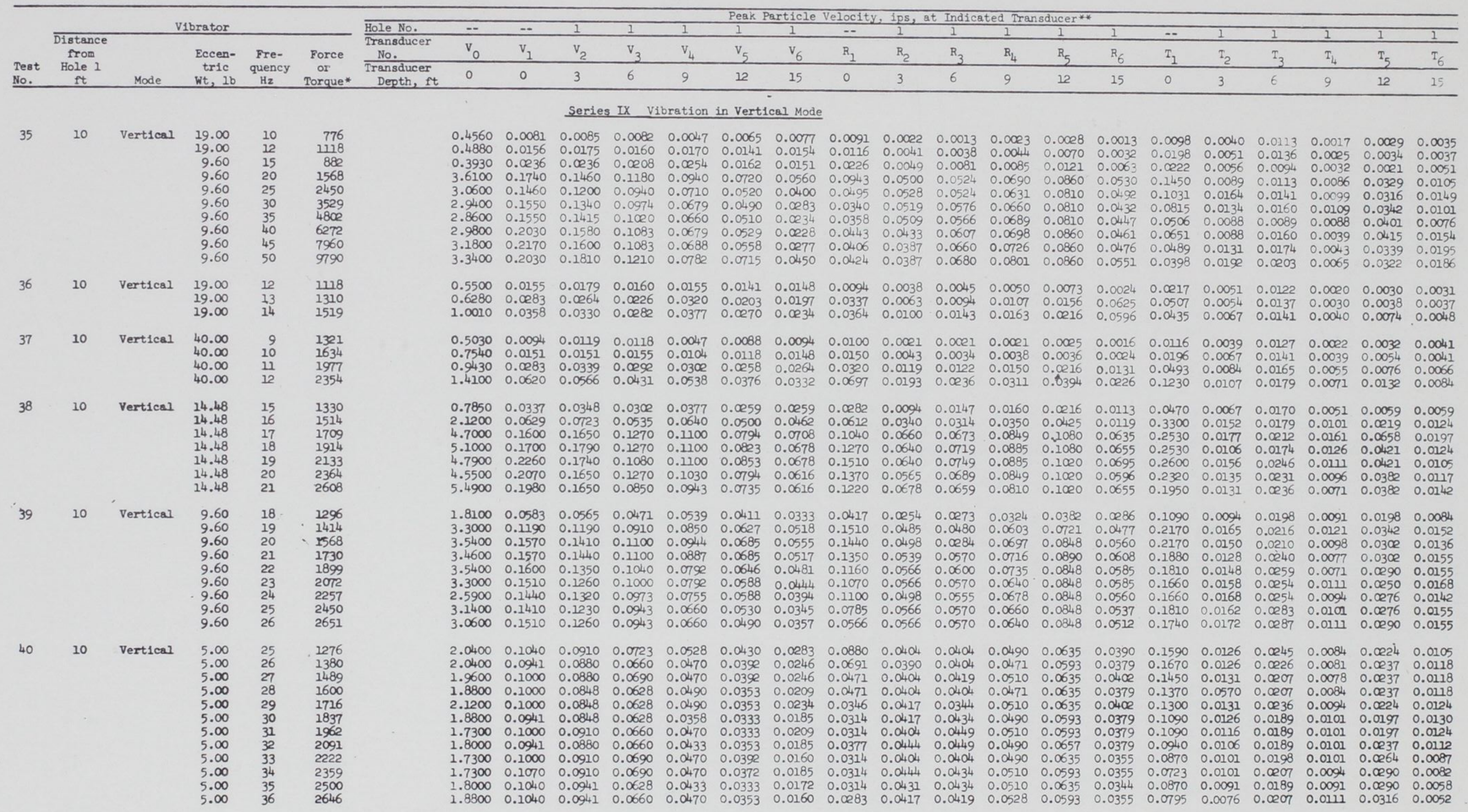

(cont1nued)

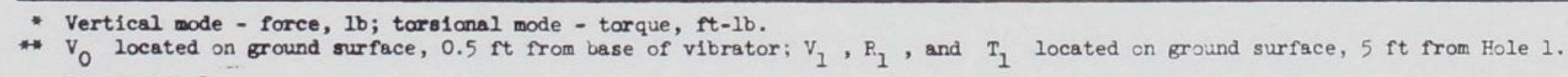

$\mathrm{V}=$ vertical
$\mathrm{R}=$ ratilial
$\mathrm{T}=\mathrm{transvers}$

1 of 4 sheets $)$
} 
Table $\mathrm{D}-\hat{3}$ (Continued)

\begin{tabular}{|c|c|c|c|c|c|}
\hline & \multicolumn{5}{|c|}{ Vibrator } \\
\hline $\begin{array}{l}\text { Test } \\
\text { To. }\end{array}$ & $\begin{array}{c}\text { Distance } \\
\text { from } \\
\text { Hole } 1 \\
\text { ft }\end{array}$ & Mode & $\begin{array}{l}\text { Ecen- } \\
\text { tric } \\
\text { th } 10\end{array}$ & $\begin{array}{c}\text { Fre- } \\
\text { quency } \\
\mathrm{Hz}\end{array}$ & $\begin{array}{l}\text { Force } \\
\text { or } \\
\text { Torgue }\end{array}$ \\
\hline 41 & 10 & Torsional & $\begin{array}{l}5.00 \\
5.00 \\
5500 \\
5.00 \\
5.00 \\
5500 \\
5.00 \\
5.00 \\
5500 \\
5.00 \\
5.00 \\
5.00\end{array}$ & $\begin{array}{l}25 \\
26 \\
27 \\
28 \\
29 \\
30 \\
31 \\
32 \\
33 \\
34 \\
35 \\
36\end{array}$ & $\begin{array}{l}1276 \\
1380 \\
1489 \\
1600 \\
1716 \\
1837 \\
1962 \\
2091 \\
22222 \\
2359 \\
2500 \\
2646\end{array}$ \\
\hline
\end{tabular}

\begin{tabular}{|c|c|c|c|c|}
\hline 42 & 10 & Torsional & $\begin{array}{l}9.6 \\
9.6 \\
9.6 \\
9.6 \\
9.6 \\
9.6 \\
9.6 \\
9.6 \\
9.6\end{array}$ & \\
\hline 43 & 10 & Torsional & $\begin{array}{r}19 . \alpha \\
19 . \alpha \\
19.0 \\
9.6 \\
9.6 \\
9.6 \\
9.6 \\
9.6 \\
9.6 \\
9.6\end{array}$ & \\
\hline 44 & 10 & Torsional & $\begin{array}{l}19 . \alpha \\
19.0 \\
19.0 \\
19.0 \\
19.0 \\
19.0\end{array}$ & \\
\hline 45 & 10 & Torsional & $\begin{array}{l}40.0 \\
40.0 \\
40.0 \\
40.0 \\
40.0\end{array}$ & \\
\hline 46 & 10 & Torsional & $\begin{array}{l}14.4 \\
14.4 \\
14.4 \\
14.4 \\
14.4 \\
14.4\end{array}$ & \\
\hline
\end{tabular}

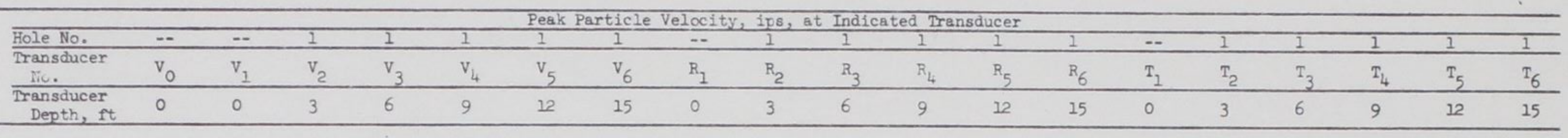
Series IX Vibration in Torsional Kode

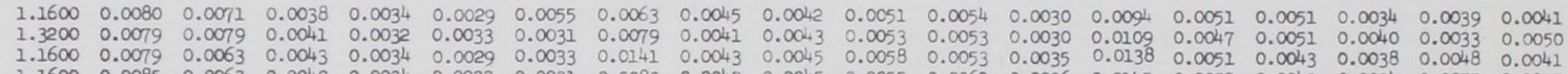

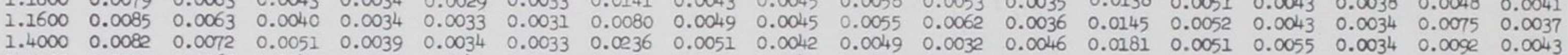

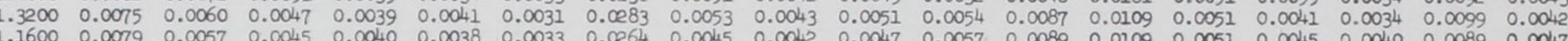

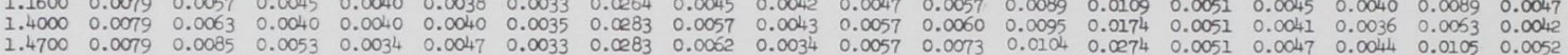

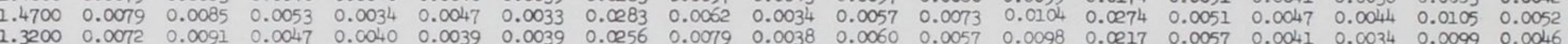

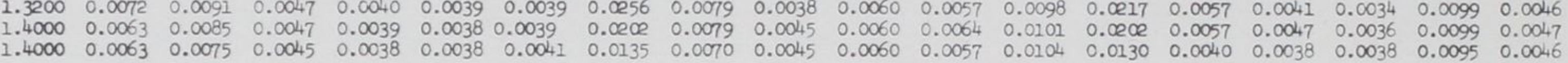

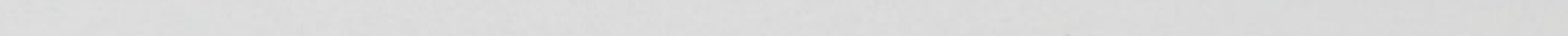

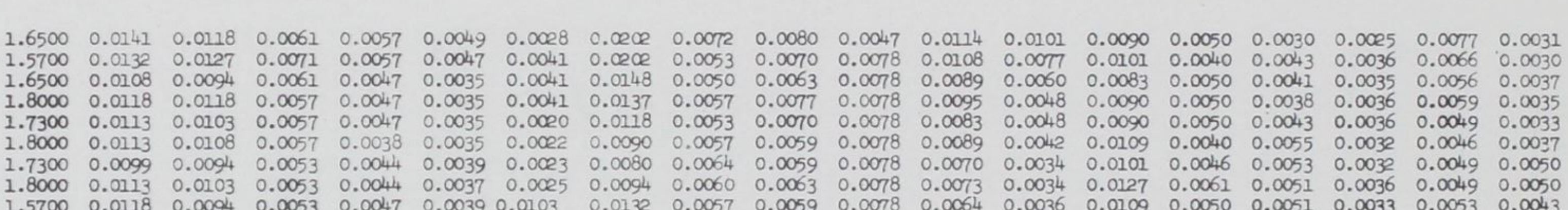
$\begin{array}{llllllllllllllllllll}.5700 & 0.0118 & 0.0094 & 0.0053 & 0.0047 & 0.0039 & 0.0103 & 0.0132 & 0.0057 & 0.0059 & 0.0078 & 0.0064 & 0.0036 & 0.0109 & 0.0050 & 0.0051 & 0.00033 & 0.0053 & 0.0043\end{array}$

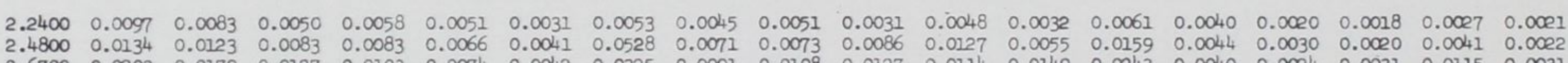

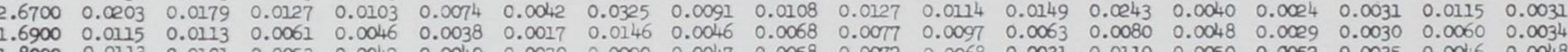

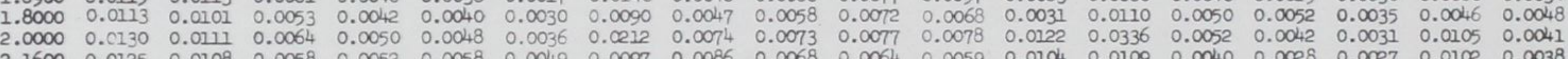

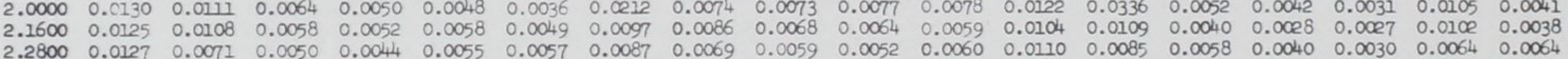

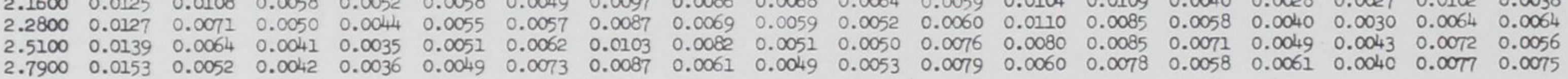

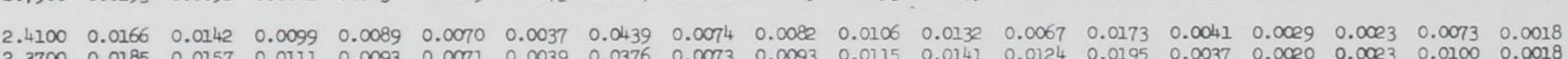

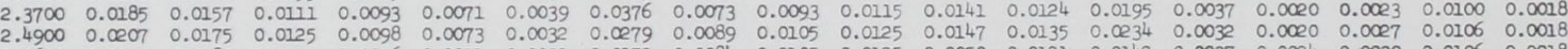

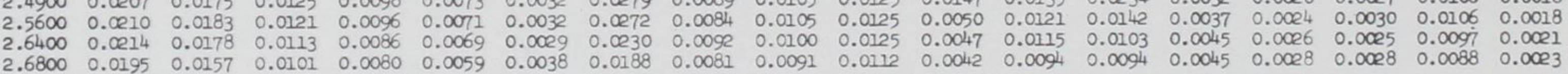

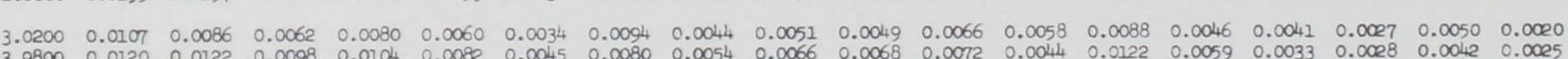

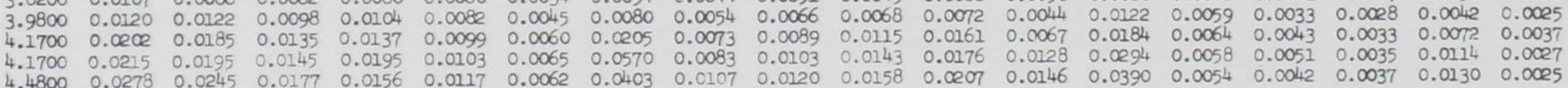
$\begin{array}{lllllllllllllllllll}.1000 & 0.0161 & 0.0125 & 0.0089 & 0.0071 & 0.0056 & 0.0028 & 0.0264 & 0.0066 & 0.0079 & 0.0098 & 0.0127 & 0.0113 & 0.0187 & 0.0047 & 0.0021 & 0.0022 & 0.0080 & 0.0021\end{array}$

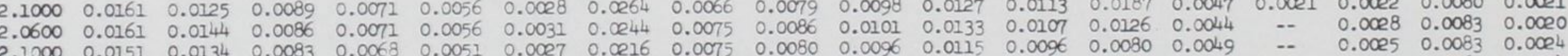

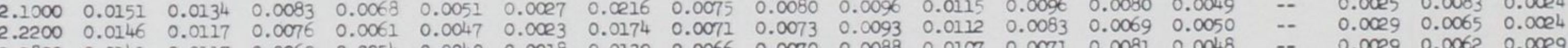

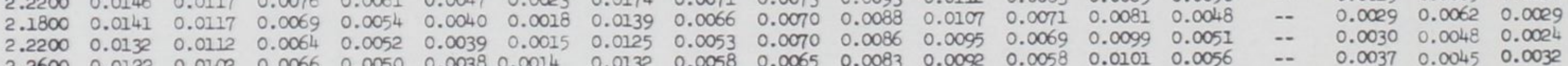


Table D-3 (Cortinued)

\begin{tabular}{|c|c|c|c|c|c|c|c|c|c|c|c|c|c|c|c|c|c|c|c|c|c|c|c|c|c|}
\hline & & & & & & & & & & & & & 1 & & & & & & & & & & & & \\
\hline & $\begin{array}{l}\text { trom } \\
\text { trole } \\
\text { tal }\end{array}$ & & $\begin{array}{c}\text { Eccen- } \\
\text { tric }\end{array}$ & $\begin{array}{l}\text { Fre-- } \\
\text { Fuency }\end{array}$ & $\begin{array}{l}\text { Force } \\
\text { or }\end{array}$ & 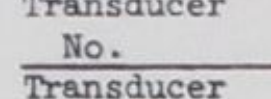 & $v_{0}$ & $v_{1}$ & $v_{2}$ & $v_{3}$ & $\mathrm{v}_{4}$ & $v_{5}$ & $v_{6}$ & $R_{1}$ & $\mathrm{R}_{2}$ & $R_{3}$ & $R_{4}$ & $R_{5}$ & $\mathrm{R}_{6}$ & $\mathrm{~T}_{1}$ & $\mathrm{~T}_{2}$ & $\mathrm{~T}_{3}$ & $\tau_{4}$ & $\mathrm{~T}_{5}$ & $\mathrm{~T}_{6}$ \\
\hline & & Mode & $w_{\mathrm{wt}, \text {, }} \mathrm{b}$ & 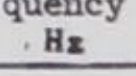 & $\begin{array}{l}\text { Torque } \\
\text { Tor }\end{array}$ & $\begin{array}{l}\text { rastacer } \\
\text { Depth, ff }\end{array}$ & & & 3 & 6 & 9 & 12 & 15 & - & 3 & 6 & 9 & 12 & 15 & $\circ$ & 3 & 6 & 9 & 12 & 15 \\
\hline & & & & & & & & Seri & $\operatorname{ces} \delta \mathrm{V}$ & ibration & in forsi & Lona1 Mod & de (cont1 & inued) & & & & & & & & & & & \\
\hline 47 & 。 & Torsional & $\begin{array}{r}14.48 \\
14.48 \\
14.48 \\
14.48 \\
14.48 \\
14.48 \\
14.48\end{array}$ & $\begin{array}{l}15 \\
16 \\
17 \\
18 \\
19 \\
20 \\
21\end{array}$ & $\begin{array}{r}778 \\
885 \\
1000 \\
1120 \\
1245 \\
1380 \\
1525\end{array}$ & & $\begin{array}{l}2.6400 \\
2.56500 \\
2.52500 \\
2.50000 \\
2.56500 \\
2.55200 \\
2.56000\end{array}$ & $\begin{array}{l}0.0622 \\
0.05399 \\
0.0521 \\
0.0538 \\
0.0505 \\
0.0477 \\
0.0455\end{array}$ & $\begin{array}{l}0.1000 \\
0.0852 \\
0.0755 \\
0.0657 \\
0.0560 \\
0.0585 \\
0.0510\end{array}$ & $\begin{array}{l}0.0332 \\
0.02073 \\
0.02054 \\
0.02014 \\
0.0185 \\
0.0186 \\
0.0166 \\
0.0166\end{array}$ & $\begin{array}{l}0.0551 \\
0.0202 \\
0.0174 \\
0.0173 \\
0.0132 \\
0.0138 \\
0.0118 \\
0.09090\end{array}$ & $\begin{array}{l}0.0146 \\
0.0126 \\
0.0110 \\
0.01103 \\
0.0000 \\
0.0095 \\
0.00659 \\
0.0069\end{array}$ & $\begin{array}{l}0.0064 \\
0.0055 \\
0.0053 \\
0.0004 \\
0.00036 \\
0.00036 \\
0.0036 \\
0.0036\end{array}$ & $\begin{array}{l}0.0666 \\
0.0666 \\
0.0585 \\
0.0554 \\
0.0455 \\
0.0453 \\
0.0438 \\
0.0505\end{array}$ & $\begin{array}{l}0.0210 \\
0.0224 \\
0.0239 \\
0.0248 \\
0.0273 \\
0.0278 \\
0.0038 \\
0.0332\end{array}$ & $\begin{array}{l}0.0089 \\
0.00077 \\
0.0006 \\
0.0008 \\
0.008 \\
0.0108 \\
0.0110 \\
0.0126\end{array}$ & $\begin{array}{l}0.0066 \\
0.0066 \\
0.0056 \\
0.0050 \\
0.0058 \\
0.0060 \\
0.0060 \\
0.0117\end{array}$ & $\begin{array}{l}0.0067 \\
0.0067 \\
0.00663 \\
0.0059 \\
0.0058 \\
0.0068 \\
0.0061 \\
0.0074\end{array}$ & $\begin{array}{l}0.0050 \\
0.00555 \\
0.0054 \\
0.0053 \\
0.0053 \\
0.00555 \\
0.00554 \\
0.0054\end{array}$ & 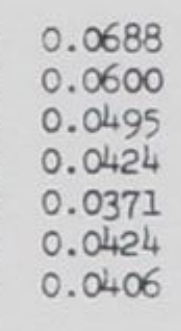 & $\begin{array}{l}0.0207 \\
0.02077 \\
0.02063 \\
0.0268 \\
0.02093 \\
0.0283 \\
0.0833 \\
0.0318\end{array}$ & $\begin{array}{l}0.0087 \\
0.00100 \\
0.00093 \\
0.0093 \\
0.0010 \\
0.01087 \\
0.0087 \\
0.0100\end{array}$ & $\begin{array}{l}0.0073 \\
0.0076 \\
0.0059 \\
0.0049 \\
0.0058 \\
0.0058 \\
0.0052 \\
0.0054\end{array}$ & $\begin{array}{l}0.0098 \\
0.010101 \\
0.01014 \\
0.0078 \\
0.0078 \\
0.0062 \\
0.0062 \\
0.0067\end{array}$ & $\begin{array}{l}0.0052 \\
0.0551 \\
0.0049 \\
0.04047 \\
0.0044 \\
0.04045 \\
0.0056\end{array}$ \\
\hline 48 & 。 & Torsiona 1 & $\begin{array}{l}9.60 \\
9.60 \\
9.60 \\
99.60 \\
9.60 \\
9.60 \\
9.60 \\
9.60 \\
9.60\end{array}$ & $\begin{array}{l}18 \\
19 \\
20 \\
21 \\
22 \\
23 \\
24 \\
25 \\
26\end{array}$ & $\begin{array}{r}742 \\
827 \\
916 \\
1010 \\
1110 \\
1210 \\
1320 \\
1340 \\
1550\end{array}$ & & 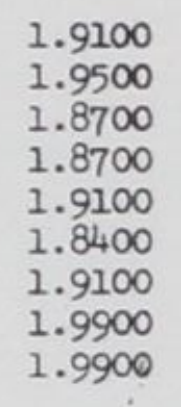 & 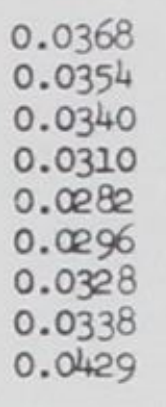 & $\begin{array}{l}0.04988 \\
0.04778 \\
0.0468 \\
0.0516 \\
0.0440 \\
0.0420 \\
0.0425 \\
0.0425 \\
0.0446 \\
0.0390\end{array}$ & $\begin{array}{l}0.0153 \\
0.01138 \\
0.0134 \\
0.0119 \\
0.0110 \\
0.0100 \\
0.01005 \\
0.01010 \\
0.0110 \\
0.0105\end{array}$ & $\begin{array}{l}0.0197 \\
0.00098 \\
0.00088 \\
0.0001 \\
0.0001 \\
0.0009 \\
0.0005 \\
0.0055 \\
0.0002 \\
0.0047\end{array}$ & 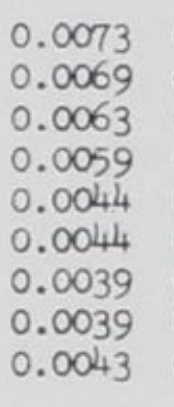 & 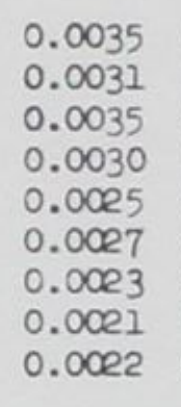 & 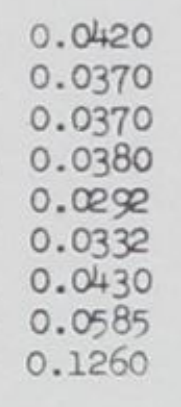 & 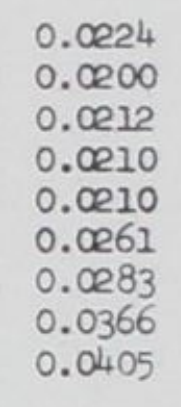 & $\begin{array}{l}0.0075 \\
0.0000 \\
0.0007 \\
0.0006 \\
0.0007 \\
0.0105 \\
0.0177 \\
0.0117 \\
0.0121 \\
0.0128\end{array}$ & $\begin{array}{l}0.0042 \\
0.00049 \\
0.000414 \\
0.00050 \\
0.0072 \\
0.0066 \\
0.0066 \\
0.0109 \\
0.01090 \\
0.0114\end{array}$ & 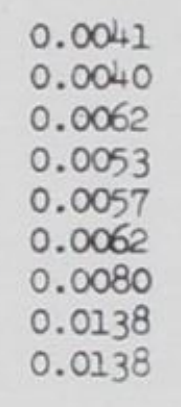 & 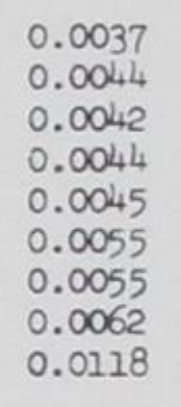 & 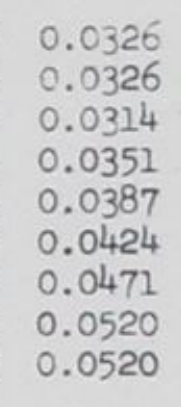 & 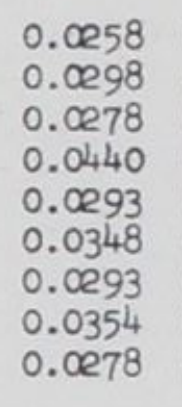 & $\begin{array}{l}0.0083 \\
0.0100 \\
0.01000 \\
0.0100 \\
0.01012 \\
0.0102 \\
0.0100 \\
0.0105 \\
0.0105 \\
0.0100\end{array}$ & $\begin{array}{l}0.0053 \\
0.00044 \\
0.0059 \\
0.0051 \\
0.0013 \\
0.0045 \\
0.0045 \\
0.0057 \\
0.0058 \\
0.00082\end{array}$ & 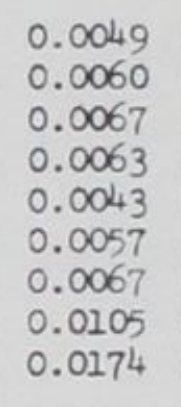 & $\begin{array}{l}0.0014 \\
0.0049 \\
0.0056 \\
0.0053 \\
0.0047 \\
0.0052 \\
0.0052 \\
0.0059 \\
0.0065\end{array}$ \\
\hline 49 & 。 & Torsional & $\begin{array}{r}19.00 \\
19.00 \\
19.00 \\
9.60 \\
9.60 \\
9.60 \\
9.60 \\
9.60 \\
9.60 \\
9.60\end{array}$ & $\begin{array}{l}10 \\
12 \\
15 \\
20 \\
25 \\
30 \\
35 \\
40 \\
45 \\
50\end{array}$ & 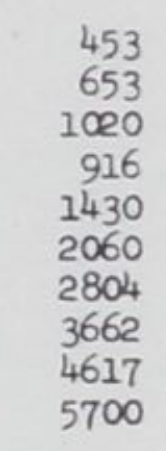 & & 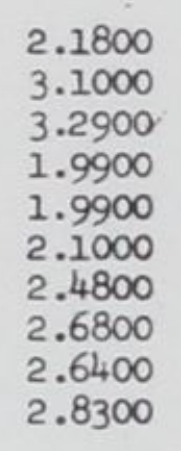 & 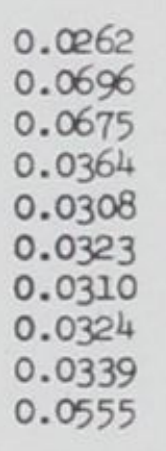 & 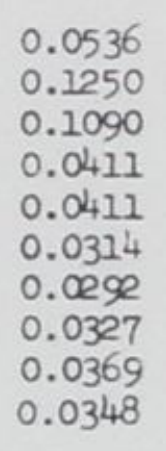 & 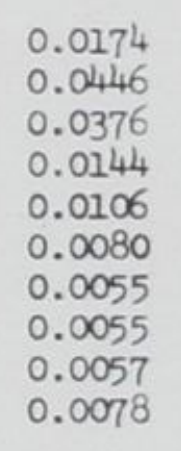 & 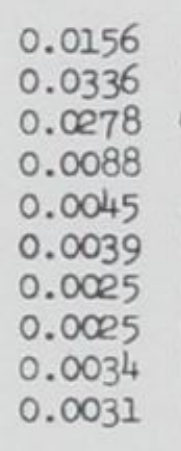 & 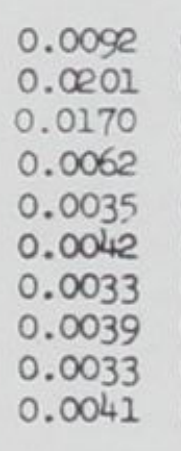 & 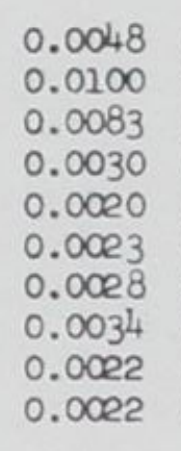 & 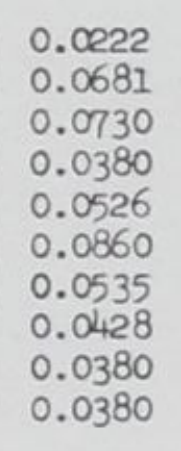 & 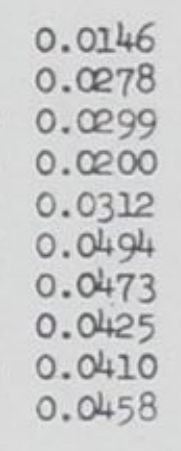 & 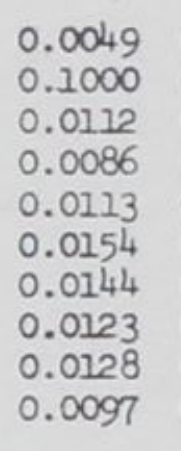 & 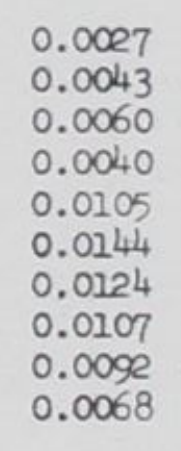 & 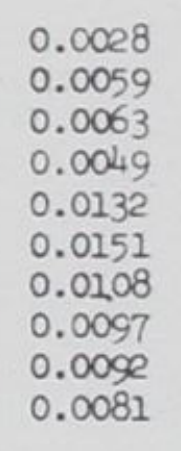 & 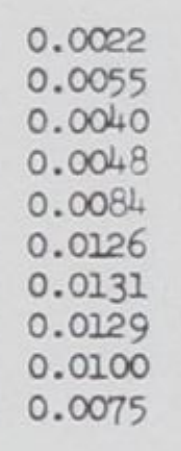 & 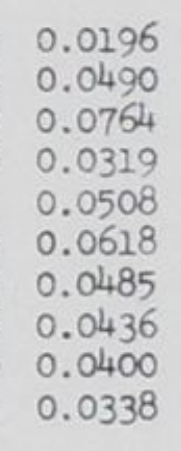 & 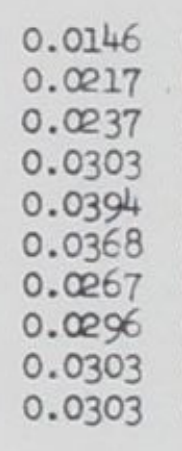 & 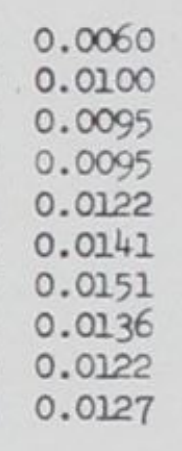 & 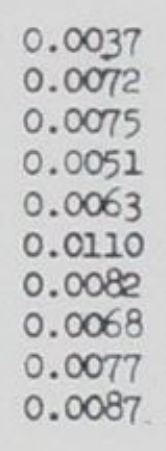 & 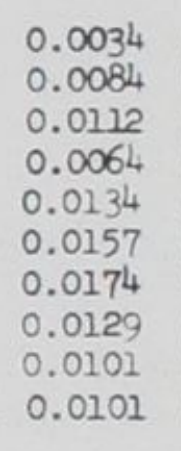 & 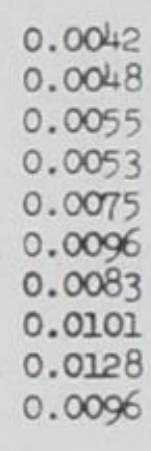 \\
\hline 50 & $\circ$ & Torsiona 1 & $\begin{array}{l}19.00 \\
19.00 \\
19.00 \\
19.00 \\
19.00 \\
19.00\end{array}$ & $\begin{array}{l}13 \\
14 \\
15 \\
16 \\
17 \\
18\end{array}$ & $\begin{array}{r}766 \\
888 \\
1080 \\
11960 \\
1310 \\
1468\end{array}$ & & $\begin{array}{l}3.1 .1400 \\
3.1000 \\
3.11800 \\
3.1000 \\
3.100000 \\
3.1000\end{array}$ & $\begin{array}{l}0.06666 \\
0.0677 \\
0.060616 \\
0.0596 \\
0.0566 \\
0.0535\end{array}$ & $\begin{array}{l}0.1310 \\
0.1230 \\
0.12150 \\
0.091010 \\
0.0746 \\
0.06988\end{array}$ & 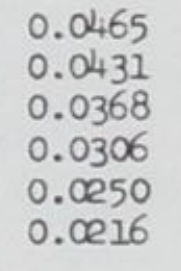 & $\begin{array}{l}0.0340 \\
0.0326 \\
0.02727 \\
0.02024 \\
0.0195 \\
0.0165\end{array}$ & $\begin{array}{l}0.0060 \\
0.0200 \\
0.0164 \\
0.0164 \\
0.0149 \\
0.0128 \\
0.0108\end{array}$ & $\begin{array}{l}0.01000 \\
0.0008 \\
0.0000 \\
0.0009 \\
0.0006 \\
0.0054\end{array}$ & $\begin{array}{l}0.0763 \\
0.1055 \\
0.02828 \\
0.0650 \\
0.0595 \\
0.0520\end{array}$ & 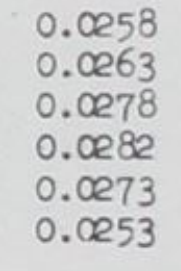 & $\begin{array}{l}0.0044 \\
0.0127 \\
0.02094 \\
0.0109 \\
0.0110 \\
0.0119\end{array}$ & $\begin{array}{l}0.0055 \\
0.0055 \\
0.0006 \\
0.00040 \\
0.0030 \\
0.00382\end{array}$ & $\begin{array}{l}0.0075 \\
0.0007 \\
0.00050 \\
0.0055 \\
0.00046 \\
0.00447\end{array}$ & $\begin{array}{l}0.0 .047 \\
0.00010 \\
0.00035 \\
0.00049 \\
0.00014 \\
0.0051\end{array}$ & $\begin{array}{l}0.0556 \\
0.0774 \\
0.0700 \\
0.06005 \\
0.0520 \\
0.04771\end{array}$ & 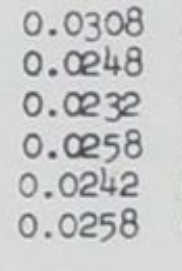 & $\begin{array}{l}0.0085 \\
0.0107 \\
0.01020 \\
0.01000 \\
0.0097 \\
0.0100\end{array}$ & $\begin{array}{l}0.0053 \\
0.0051 \\
0.0059 \\
0.00047 \\
0.0049 \\
0.0051\end{array}$ & $\begin{array}{l}0.0095 \\
0.0123 \\
0.0121 \\
0.0007 \\
0.00098 \\
0.0087\end{array}$ & $\begin{array}{l}0.0 .044 \\
0.0093 \\
0.0047 \\
0.00035 \\
0.0035 \\
0.00214\end{array}$ \\
\hline 51 & $\circ$ & Torsional & $\begin{array}{l}40.00 \\
40.00 \\
40.00 \\
40.00 \\
40.00\end{array}$ & $\begin{array}{l}9 \\
10 \\
11 \\
12 \\
13\end{array}$ & $\begin{array}{r}773 \\
955 \\
1153 \\
1373 \\
1610\end{array}$ & & 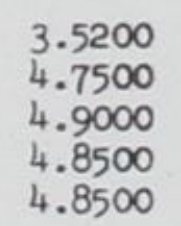 & $\begin{array}{l}0.0323 \\
0.0616 \\
0.0658 \\
0.05954 \\
0.09950\end{array}$ & $\begin{array}{l}0.0684 \\
0.1150 \\
0.1560 \\
0.1580 \\
0.1620\end{array}$ & $\begin{array}{l}0.02222 \\
0.0410 \\
0.0456 \\
0.0555 \\
0.06525 \\
0.0570\end{array}$ & $\begin{array}{l}0.0190 \\
0.0355 \\
0.0352 \\
0.0228 \\
0.0462 \\
0.0423\end{array}$ & $\begin{array}{l}0.0113 \\
0.0190 \\
0.01926 \\
0.0268 \\
0.0268 \\
0.0442\end{array}$ & $\begin{array}{l}0.0062 \\
0.0013 \\
0.0136 \\
0.0136 \\
0.0133 \\
0.0121\end{array}$ & $\begin{array}{l}0.0373 \\
0.0715 \\
0.1010 \\
0.1000 \\
0.1260\end{array}$ & $\begin{array}{l}0.0165 \\
0.0169 \\
0.0350 \\
0.0355 \\
0.0425 \\
0.0466\end{array}$ & $\begin{array}{l}0.0052 \\
0.0106 \\
0.0128 \\
0.0007 \\
0.0077 \\
0.0164\end{array}$ & $\begin{array}{l}0.0036 \\
0.0054 \\
0.0088 \\
0.0089 \\
0.0089 \\
0.0106\end{array}$ & $\begin{array}{l}0.0030 \\
0.0078 \\
0.0088 \\
0.0019 \\
0.0119 \\
0.0121\end{array}$ & $\begin{array}{l}0.0025 \\
0.0047 \\
0.00075 \\
0.0005 \\
0.0118 \\
0.0121\end{array}$ & $\begin{array}{l}0.0246 \\
0.0443 \\
0.04727 \\
0.04029 \\
0.00962\end{array}$ & $\begin{array}{l}0.0187 \\
0.0187 \\
0.0242 \\
0.02027 \\
0.0888 \\
0.0313\end{array}$ & $\begin{array}{l}0.0056 \\
0.0095 \\
0.0 .0956 \\
0.01026 \\
0.0126\end{array}$ & $\begin{array}{l}0.0037 \\
0.00050 \\
0.0060 \\
0.00079 \\
0.0074\end{array}$ & $\begin{array}{l}0.0027 \\
0.0024 \\
0.00041 \\
0.00012 \\
0.0123 \\
0.0137\end{array}$ & $\begin{array}{l}0.0030 \\
0.00044 \\
0.0057 \\
0.0063 \\
0.0067\end{array}$ \\
\hline 58 & 。 & Torsional & $\begin{array}{l}5.00 \\
5.00 \\
5.00 \\
5.00 \\
5.00 \\
5.00 \\
5.00 \\
5.00 \\
5.00 \\
5.00 \\
5.00 \\
5.00\end{array}$ & $\begin{array}{l}25 \\
26 \\
27 \\
28 \\
29 \\
30 \\
31 \\
32 \\
33 \\
34\end{array}$ & $\begin{array}{r}745 \\
806 \\
870 \\
935 \\
1030 \\
1007 \\
1145 \\
1220 \\
1300 \\
1380 \\
1460 \\
1550\end{array}$ & & 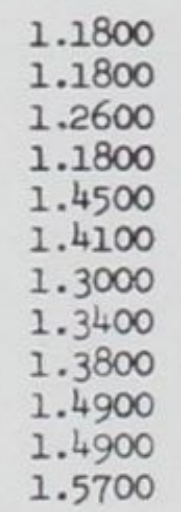 & 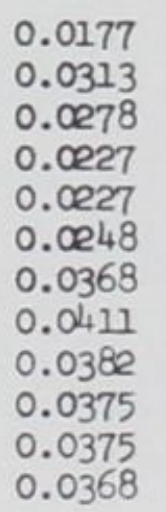 & $\begin{array}{l}0.0311 \\
0.0316 \\
0.0316 \\
0.0322 \\
0.0325 \\
0.0365 \\
0.0356 \\
0.022929 \\
0.02925 \\
0.0253 \\
0.02038 \\
0.02533 \\
0.0263\end{array}$ & 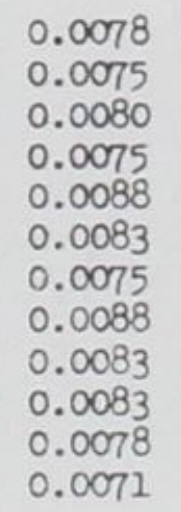 & 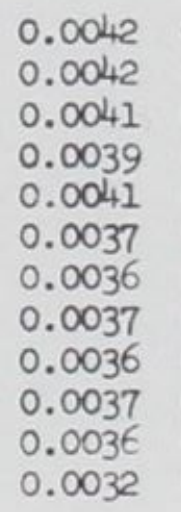 & 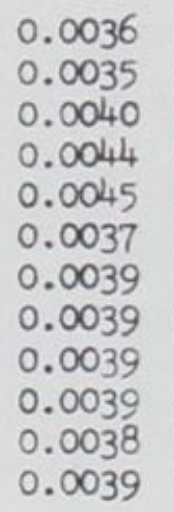 & 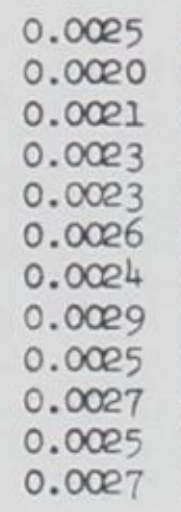 & 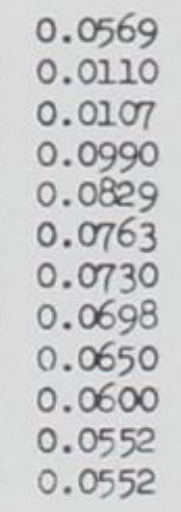 & 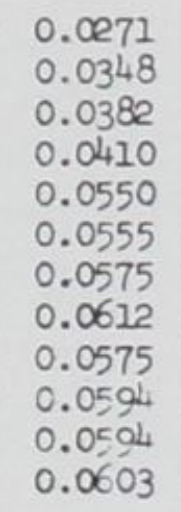 & $\begin{array}{l}0.01010 \\
0.0114 \\
0.0126 \\
0.01262 \\
0.01912 \\
0.0220 \\
0.0220 \\
0.0226 \\
0.0215 \\
0.0189 \\
0.0194 \\
0.0210\end{array}$ & 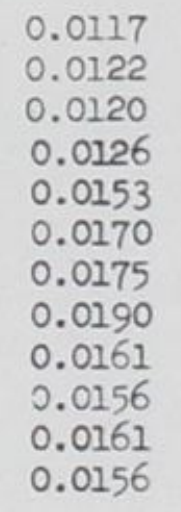 & 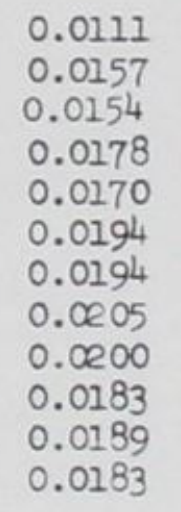 & 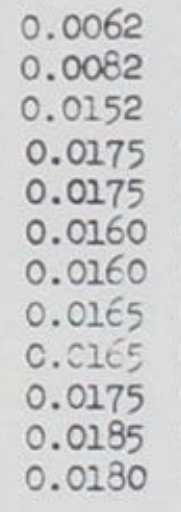 & 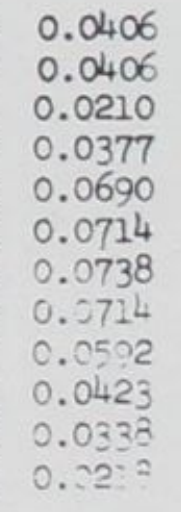 & 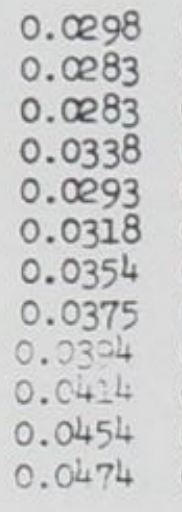 & 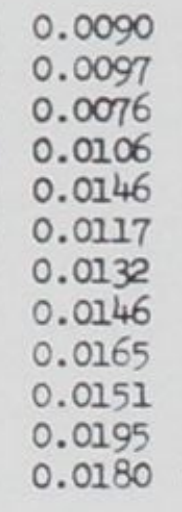 & 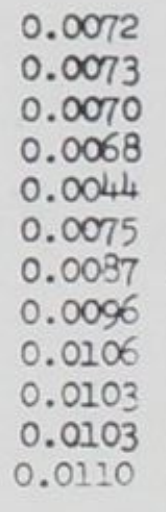 & 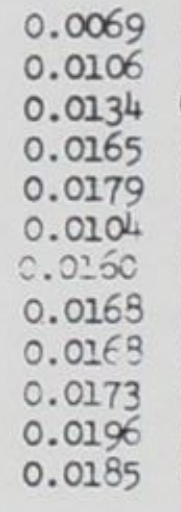 & 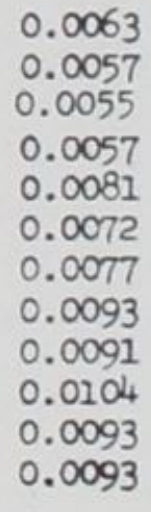 \\
\hline
\end{tabular}


Table D-3 (Concluded)

\begin{tabular}{|c|c|c|c|c|c|c|c|c|c|c|c|c|c|c|c|c|c|c|c|c|c|c|c|c|c|}
\hline & & & brator & & & 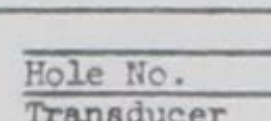 & $\pi$ & -- & & & - & eak & 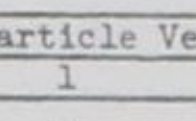 & - & 2 & $\frac{1201}{12}$ & $\frac{d \tan s}{1}$ & $\begin{array}{l}\text { sducer } \\
\text { inu }\end{array}$ & & & & & & T- & 1 \\
\hline & Distancana & & Eccen- & Fre- & force & & $v_{0}$ & $v_{1}$ & $v_{2}$ & $v_{3}$ & $v_{4}$ & $v_{5}$ & $\mathrm{v}_{6}$ & $R_{1}$ & $R_{2}$ & $R_{3}$ & $R_{4}$ & $R_{5}$ & $\mathrm{R}_{6}$ & $T_{1}$ & $\mathrm{~T}_{2}$ & $T_{3}$ & $\pi_{4}$ & $T_{5}$ & $\mathrm{~T}_{6}$ \\
\hline & & Mode & $\operatorname{tr} 1$ & $\begin{array}{c}\text { quencency } \\
-\mathrm{Hz}_{3}\end{array}$ & $\begin{array}{l}\text { or } \\
\text { Torque }\end{array}$ & $\begin{array}{l}\text { cer } \\
\text { itt }\end{array}$ & $\circ$ & $\circ$ & 3 & 6 & 9 & 12 & 15 & 0 & 3 & 6 & 9 & 12 & 25 & 0 & 3 & 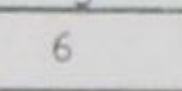 & 9 & 12 & 15 \\
\hline & & & & & & & & & Serie & es $x$ Vib & bration 1 & ic & cal Mode & & & & & & & & & & & & \\
\hline 53 & $\sigma$ & vertical & $\begin{array}{l}5.00 \\
5.00 \\
5.00 \\
5.00 \\
5.00 \\
5.00 \\
5.00 \\
5.00 \\
5.00 \\
5.00 \\
5.00 \\
5.00\end{array}$ & $\begin{array}{l}25 \\
26 \\
27 \\
28 \\
29 \\
30 \\
31 \\
32 \\
33 \\
34 \\
35 \\
36\end{array}$ & $\begin{array}{l}1276 \\
1380 \\
1489 \\
1600 \\
1716 \\
1837 \\
1962 \\
2091 \\
2222 \\
2359 \\
2550 \\
2646\end{array}$ & & 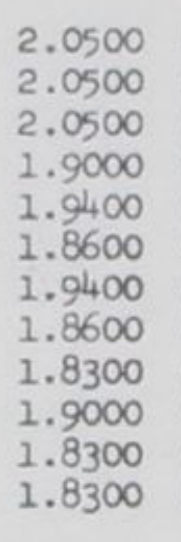 & 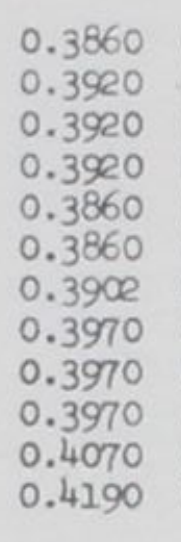 & $\begin{array}{l}0.7740 \\
0.7740 \\
0.7520 \\
0.7520 \\
0.7250 \\
0.7470 \\
0.7520 \\
0.740 \\
0.7300 \\
0.7300 \\
0.7520 \\
0.740 \\
0.7400 \\
0.7300\end{array}$ & 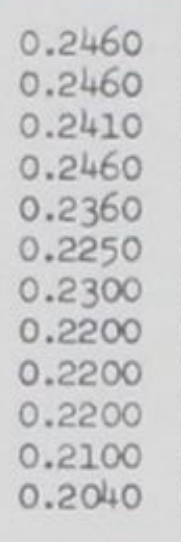 & 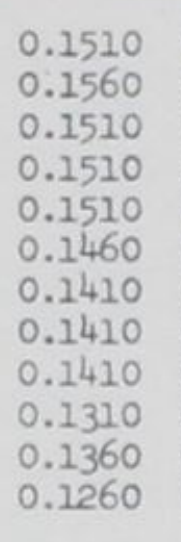 & 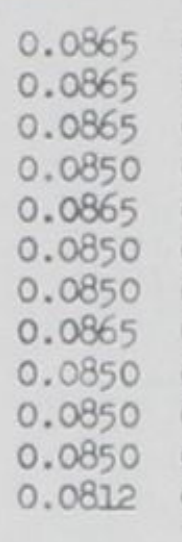 & $\begin{array}{l}0.0488 \\
0.0475 \\
0.0463 \\
0.0450 \\
0.0454 \\
0.0424 \\
0.04366 \\
0.04111 \\
0.03988 \\
0.0386 \\
0.0368 \\
0.03988 \\
0.0363 \\
0.0373\end{array}$ & 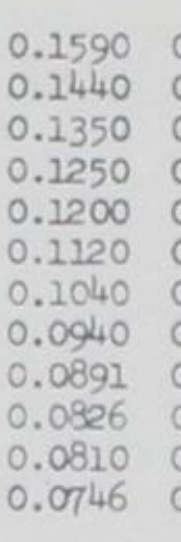 & 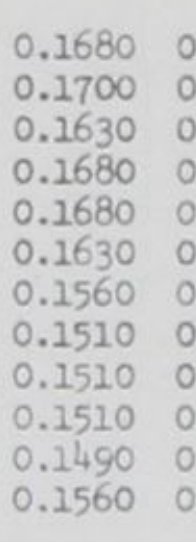 & 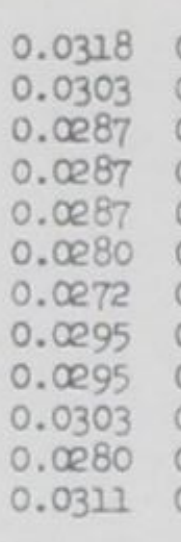 & 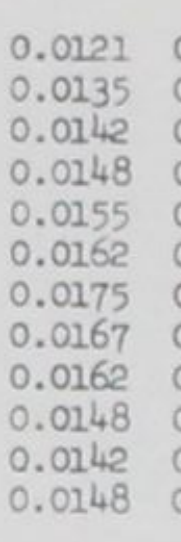 & 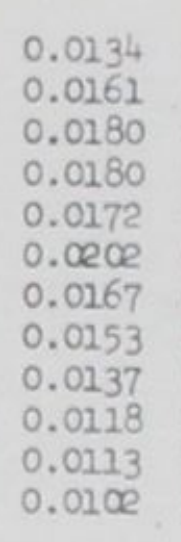 & $\begin{array}{l}0.0094 \\
0.0125 \\
0.01250 \\
0.0145 \\
0.01445 \\
0.017176 \\
0.0197 \\
0.02077 \\
0.0187 \\
0.0176 \\
0.0176 \\
0.01445 \\
0.0145 \\
0.0140\end{array}$ & 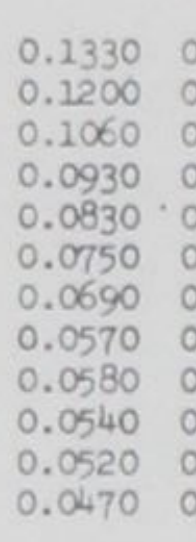 & 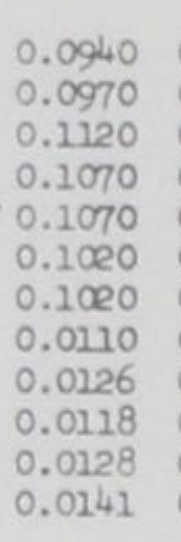 & 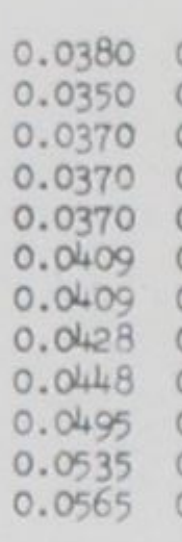 & 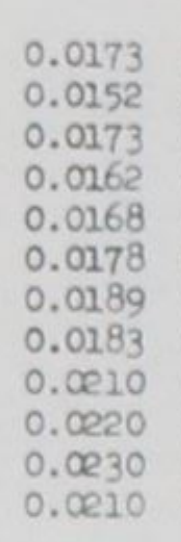 & 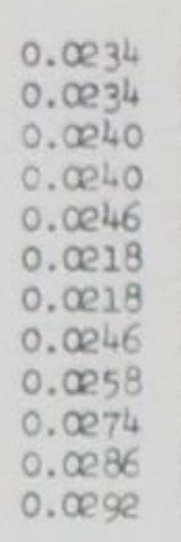 & 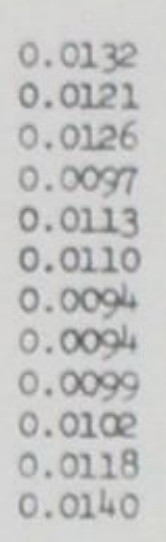 \\
\hline 54 & 。 & Vertical & $\begin{array}{l}9.60 \\
9.60 \\
9.60 \\
9.60 \\
9.60 \\
9.60 \\
9.60 \\
9.60 \\
9.60\end{array}$ & $\begin{array}{l}18 \\
19 \\
20 \\
21 \\
22 \\
23 \\
24 \\
25 \\
26\end{array}$ & $\begin{array}{l}1269 \\
1414 \\
1568 \\
1730 \\
1899 \\
20972 \\
22557 \\
2450 \\
2651\end{array}$ & & 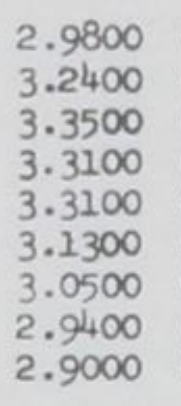 & $\begin{array}{l}0.4020 \\
0.5220 \\
0.5440 \\
0.5550 \\
0.5530 \\
0.5320 \\
0.5220 \\
0.55050 \\
0.4950 \\
0.55000\end{array}$ & $\begin{array}{l}0.9930 \\
1.11300 \\
1.2300 \\
1.2300 \\
1.2000 \\
1.12900 \\
1.1100 \\
1.1450 \\
1.1200\end{array}$ & 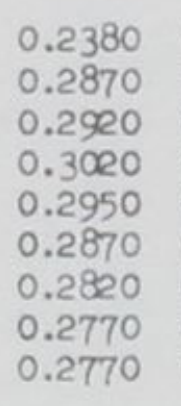 & $\begin{array}{l}0.1700 \\
0.11900 \\
0.2020 \\
0.2020 \\
0.2000 \\
0.2000 \\
0.1900 \\
0.1900 \\
0.1900 \\
0.12850\end{array}$ & $\begin{array}{l}0.0945 \\
0.1110 \\
0.11150 \\
0.1170 \\
0.1170 \\
0.1130 \\
0.11100 \\
0.1000 \\
0.1000 \\
0.1050\end{array}$ & 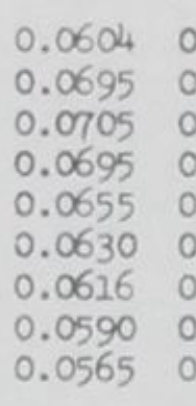 & $\begin{array}{l}0.3310 \\
0.2830 \\
0.2530 \\
0.2430 \\
0.2190 \\
0.1900 \\
0.1900 \\
0.1750 \\
0.1150 \\
0.1510\end{array}$ & 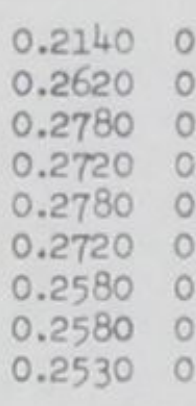 & 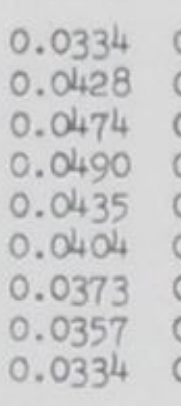 & $\begin{array}{l}0.0127 \\
0.01273 \\
0.0137 \\
0.0132 \\
0.0156 \\
0.0156 \\
0.01424 \\
0.0146 \\
0.1175\end{array}$ & 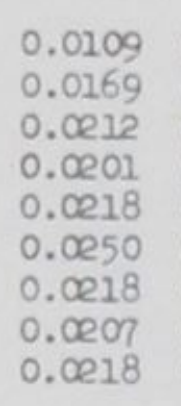 & $\begin{array}{l}0.0057 \\
0.0148 \\
0.0158 \\
0.0166 \\
0.0162 \\
0.0132 \\
0.0142 \\
0.0150 \\
0.0153 \\
0.0155 \\
0.0155\end{array}$ & $\begin{array}{l}0.1900 \\
0.3300 \\
0.2830 \\
0.2500 \\
0.2500 \\
0.2250 \\
0.18100 \\
0.1630 \\
0.1450 \\
0.1450 \\
0.1310\end{array}$ & 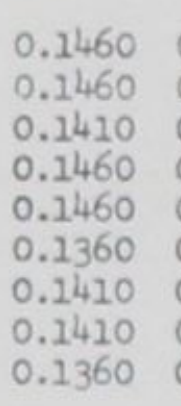 & 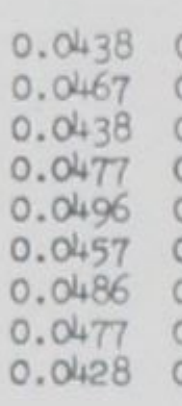 & 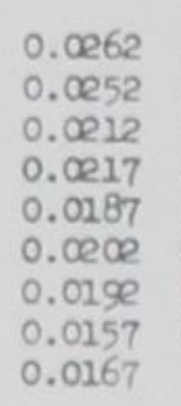 & 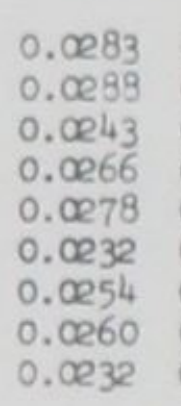 & 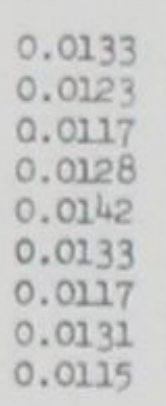 \\
\hline 55 & 。 & Vertical & $\begin{array}{r}19.00 \\
19.00 \\
9.60 \\
9.60 \\
9.60 \\
9.60 \\
9.60 \\
9.60 \\
9.60 \\
9.60\end{array}$ & $\begin{array}{l}10 \\
12 \\
15 \\
20 \\
25 \\
30 \\
35 \\
40 \\
45 \\
50\end{array}$ & $\begin{array}{r}776 \\
1118 \\
882 \\
1568 \\
2450 \\
3529 \\
4802 \\
6272 \\
7906 \\
9761\end{array}$ & & 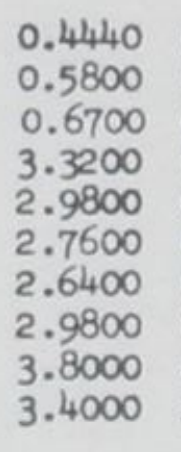 & 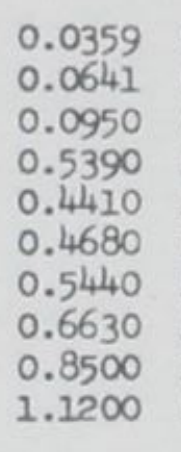 & $\begin{array}{l}0.0612 \\
0.1320 \\
0.12120 \\
0.2150 \\
1.0500 \\
1.2000 \\
1.1200 \\
1.2000 \\
1.3100 \\
1.1300\end{array}$ & 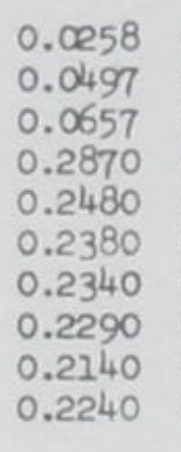 & 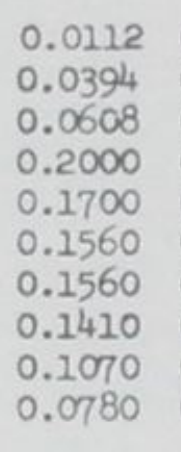 & 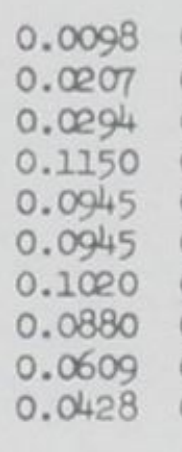 & 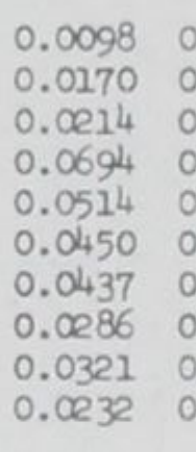 & 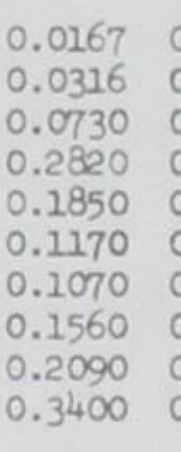 & 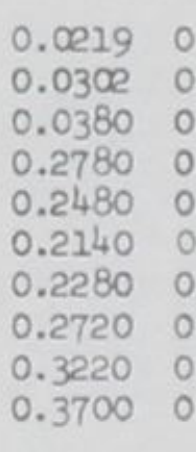 & 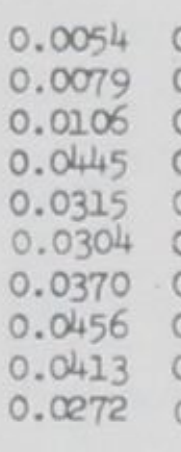 & $\begin{array}{l}0.0031 \\
0.0032 \\
0.0036 \\
0.0036 \\
0.0125 \\
0.0134 \\
0.0134 \\
0.0158 \\
0.027 \\
0.0125 \\
0.0229 \\
0.0229\end{array}$ & 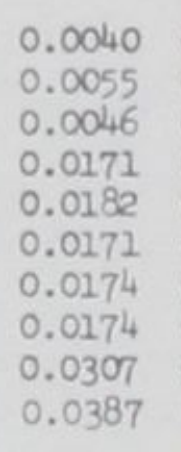 & $\begin{array}{l}0.0055 \\
0.00038 \\
0.0034 \\
0.0140 \\
0.0140 \\
0.0140 \\
0.01097 \\
0.0181 \\
0.0166 \\
0.0163 \\
0.0233 \\
0.0311\end{array}$ & 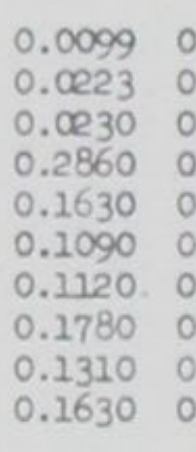 & $\begin{array}{l}0.020 \\
0.034 \\
0.0334 \\
0.0340 \\
0.140 \\
0.14200 \\
0.1460 \\
0.1480 \\
0.1990 \\
0.2220 \\
0.2300 \\
0.230\end{array}$ & 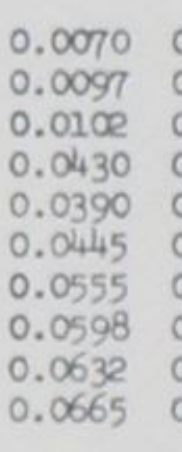 & 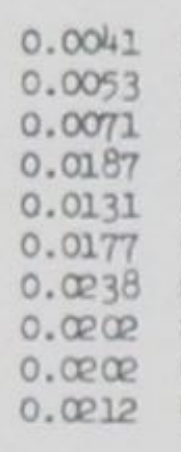 & 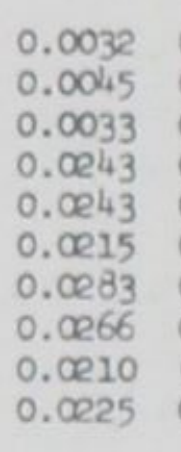 & 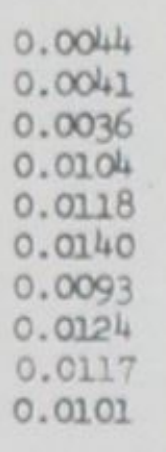 \\
\hline $56 \mathrm{~A}$ & 。 & vertical & $\begin{array}{l}19.00 \\
19.00 \\
19.00 \\
19.00\end{array}$ & $\begin{array}{l}13 \\
14 \\
15 \\
16 \\
18 \\
18\end{array}$ & $\begin{array}{l}1330 \\
1519 \\
1746 \\
1926 \\
2243 \\
2512\end{array}$ & & $\begin{array}{l}1.08000 \\
2.64000 \\
55.7000 \\
55.7000 \\
5.5000 \\
5.2000\end{array}$ & $\begin{array}{l}0.1250 \\
0.12140 \\
0.3260 \\
0.3370 \\
0.3320 \\
0.6410\end{array}$ & $\begin{array}{l}0.2900 \\
0.2670 \\
0.7600 \\
0.7600 \\
0.7450 \\
.14100\end{array}$ & $\begin{array}{l}0.1000 \\
0.0778 \\
0.1970 \\
0.1490 \\
0.144010 \\
0.3700\end{array}$ & 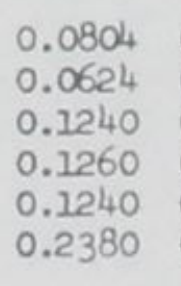 & $\begin{array}{l}0.0405 \\
0.0415 \\
0.1000 \\
0.1000 \\
0.0985 \\
0.1420\end{array}$ & 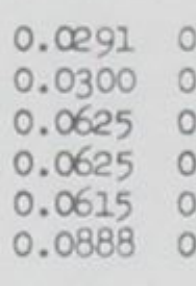 & $\begin{array}{l}0.0780 \\
0.11460 \\
0.1270 \\
0.1240 \\
0.11440 \\
.03060\end{array}$ & $\begin{array}{ll}0.080303 \\
0.1120 \\
0.240 \\
0.2500 \\
0.250 \\
0.240 \\
0.4570\end{array}$ & $\begin{array}{l}0.0141 \\
0.0236 \\
0.0994 \\
0.0288 \\
0.0288 \\
0.0555\end{array}$ & $\begin{array}{l}0.0411 \\
0.0098 \\
0.0070 \\
0.0060 \\
0.061 \\
0.0170\end{array}$ & $\begin{array}{l}0.0063 \\
0.0005 \\
0.0004 \\
0.00079 \\
0.0090 \\
0.0226\end{array}$ & 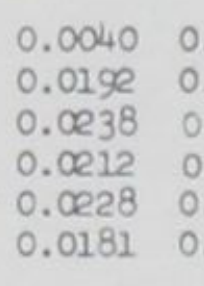 & 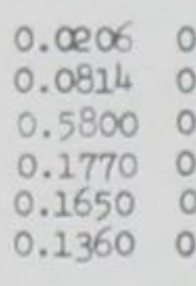 & $\begin{array}{l}0.0437 \\
0.0443 \\
0.2300 \\
0.2520 \\
0.2440 \\
0.2200\end{array}$ & $\begin{array}{l}0.0143 \\
0.0292 \\
0.0778 \\
0.085 \\
0.0756 \\
0.0705\end{array}$ & 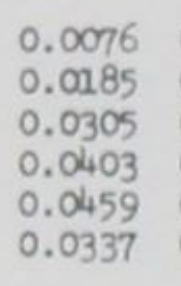 & $\begin{array}{l}0.0036 \\
0.0038 \\
0.0209 \\
0.0298 \\
0.0660 \\
0.02525 .\end{array}$ & $\begin{array}{l}0.0031 \\
0.0009 \\
0.0126 \\
0.0175 \\
0.0167 \\
0.0137\end{array}$ \\
\hline 57 & 。 & Vertical & $\begin{array}{l}14.48 \\
14.48 \\
14.48 \\
14.48 \\
14.48 \\
14.48\end{array}$ & $\begin{array}{l}15 \\
16 \\
17 \\
18 \\
19 \\
20\end{array}$ & $\begin{array}{l}1330 \\
1514 \\
1709 \\
1914 \\
2133 \\
21364 \\
23608 \\
2608\end{array}$ & & $\begin{array}{r}2.4400 \\
4.5100 \\
4.6700 \\
4.4400 \\
4.400 \\
4.1300 \\
4.1300 \\
4.1000\end{array}$ & $\begin{array}{l}0.2280 \\
0.5440 \\
0.5750 \\
0.5440 \\
0.5140 \\
0.5100 \\
0.5210 \\
0.5210\end{array}$ & $\begin{array}{l}0.5500 \\
1.1900 \\
1.2700 \\
1.2100 \\
1.2100 \\
1.1600 \\
1.1500\end{array}$ & $\begin{array}{l}0.1650 \\
0.35200 \\
0.3400 \\
0.3600 \\
0.3330 \\
0.3100 \\
0.3110 \\
0.3060\end{array}$ & $\begin{array}{l}0.1310 \\
0.2140 \\
0.2280 \\
0.2190 \\
0.2190 \\
0.2100 \\
0.200 \\
0.22440\end{array}$ & $\begin{array}{l}0.0647 \\
0.142 \\
0.1230 \\
0.1250 \\
0.15250 \\
0.1180 \\
0.1180 \\
0.1120\end{array}$ & $\begin{array}{ll}0.0462 & 0 \\
0.0795 & 0 \\
0.0848 & 0 \\
0.07955 & 0.0795 \\
0.0745 & 0 \\
0.0745 & 0 \\
0.0680 & 0\end{array}$ & $\begin{array}{l}0.2940 \\
0.2430 \\
0.2430 \\
0.2680 \\
0.3500 \\
0.350 \\
0.350 \\
. .3460\end{array}$ & 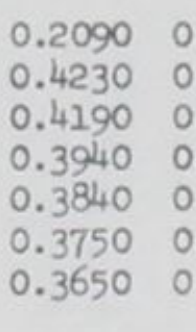 & 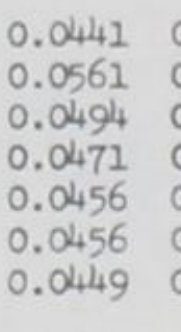 & $\begin{array}{l}0.038 \\
0.03185 \\
0.1131 \\
0.0131 \\
0.0136 \\
0.0126 \\
0.0136\end{array}$ & $\begin{array}{l}0.0066 \\
0.0278 \\
0.0223 \\
0.0215 \\
0.0158 \\
0.0158 \\
0.0198 \\
0.01998\end{array}$ & $\begin{array}{lll}0.0178 & 0 \\
0.01944 & 0 \\
0.0158 & 0 \\
0.0153 & 0 \\
0.0155 & 0 \\
0.0157 & 0 \\
0.0217 & 0 \\
0.0132 & 0\end{array}$ & $\begin{array}{lll}0.0990 & 0 \\
0.1450 & 0 \\
0.1450 & 0 \\
0.14340 & 0 \\
0.1340 & 0 \\
0.14140 & 0 \\
0.2340 & 0 \\
0.2720 & 0\end{array}$ & $\begin{array}{l}0.0864 \\
0.1600 \\
0.2400 \\
0.1900 \\
0.1830 \\
0.1650 \\
0.1650 \\
0.1650\end{array}$ & $\begin{array}{l}0.076 \\
0.0768 \\
0.0050 \\
0.0600 \\
0.0633 \\
0.0551 \\
0.0551 \\
0.0551\end{array}$ & 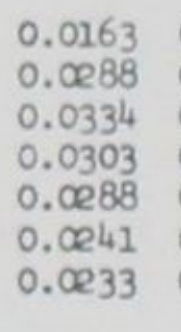 & $\begin{array}{l}0.0006 \\
0.0164 \\
0.015 \\
0.0226 \\
0.0249 \\
0.049 \\
0.049 \\
0.0254\end{array}$ & $\begin{array}{l}0.0078 \\
0.018 \\
0.0118 \\
0.0150 \\
0.0134 \\
0.0132 \\
0.013 \\
0.0113 \\
0.0116\end{array}$ \\
\hline 58 & 。 & vertical & 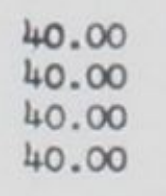 & $\begin{array}{l}99 \\
11 \\
12\end{array}$ & $\begin{array}{l}1321 \\
1634 \\
1977 \\
2354\end{array}$ & & $\begin{array}{l}0.7450 \\
1.0900 \\
2.4900 \\
2.6400\end{array}$ & $\begin{array}{l}0.0605 \\
0.07098 \\
0.0138 \\
0.2240\end{array}$ & $\begin{array}{l}0.1520 \\
0.17790 \\
0.4460 \\
0.6360\end{array}$ & $\begin{array}{l}0.0455 \\
0.0655 \\
0.1050 \\
0.1570\end{array}$ & $\begin{array}{l}0.0175 \\
0.0302 \\
0.0303 \\
0.1270\end{array}$ & $\begin{array}{l}0.0132 \\
0.0214 \\
0.0440 \\
0.0650\end{array}$ & $\begin{array}{l}0.0122 \\
0.01717 \\
0.0321 \\
0.0466\end{array}$ & $\begin{array}{l}0.0366 \\
0.0264 \\
0.2430 \\
0.2960\end{array}$ & $\begin{array}{lll}0.0312 & 0 \\
0.0327 & 0 \\
0.1560 & 0 \\
0.1960 & 0\end{array}$ & $\begin{array}{l}0.0098 \\
0.0792 \\
0.01010 \\
0.0642\end{array}$ & $\begin{array}{l}0.0034 \\
0.0037 \\
0.0303 \\
0.0404\end{array}$ & $\begin{array}{l}0.0031 \\
0.0363 \\
0.0227 \\
0.0390\end{array}$ & $\begin{array}{l}0.0036 \\
0.0313 \\
0.0166 \\
0.0044\end{array}$ & $\begin{array}{l}0.0142 \\
0.0283 \\
0.0533 \\
0.0918\end{array}$ & $\begin{array}{l}.0189 \\
.0254 \\
.0493 \\
.0655 \\
.0555\end{array}$ & $\begin{array}{l}0.0081 \\
0.0021 \\
0.01288 \\
0.0 \times 36\end{array}$ & $\begin{array}{l}0.00049 \\
0.0098 \\
0.0091 \\
0.0108\end{array}$ & $\begin{array}{l}0.0042 \\
0.0065 \\
0.0110 \\
0.0158\end{array}$ & $\begin{array}{l}0.0031 \\
0.0063 \\
0.0002 \\
0.0051\end{array}$ \\
\hline
\end{tabular}


APPENDIX E

TABULATION OF PHASE VELOCITY MEASUREMENTS BETWEEN VERTICAL TRANSDUCERS AT VARIOUS DEPTHS 


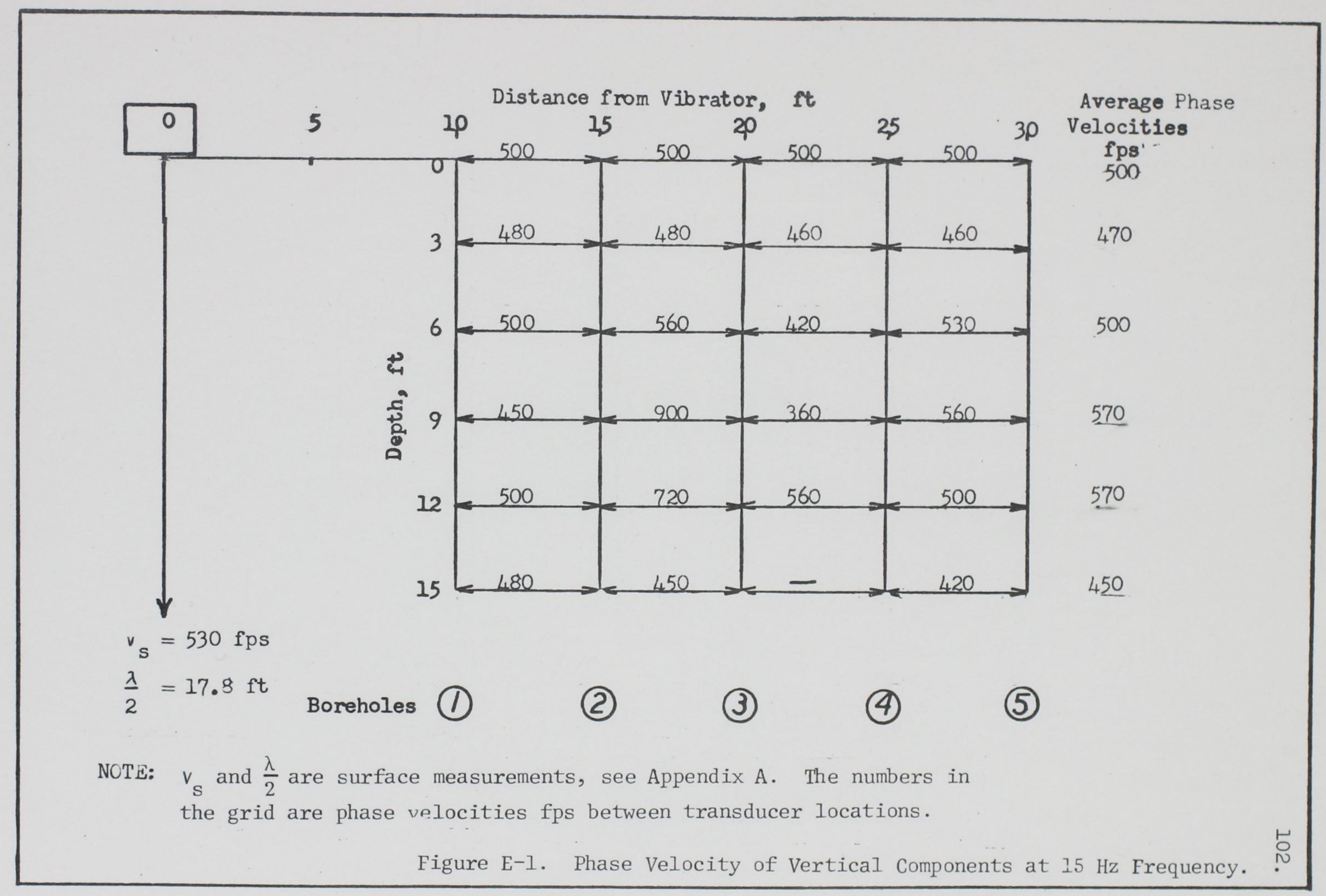




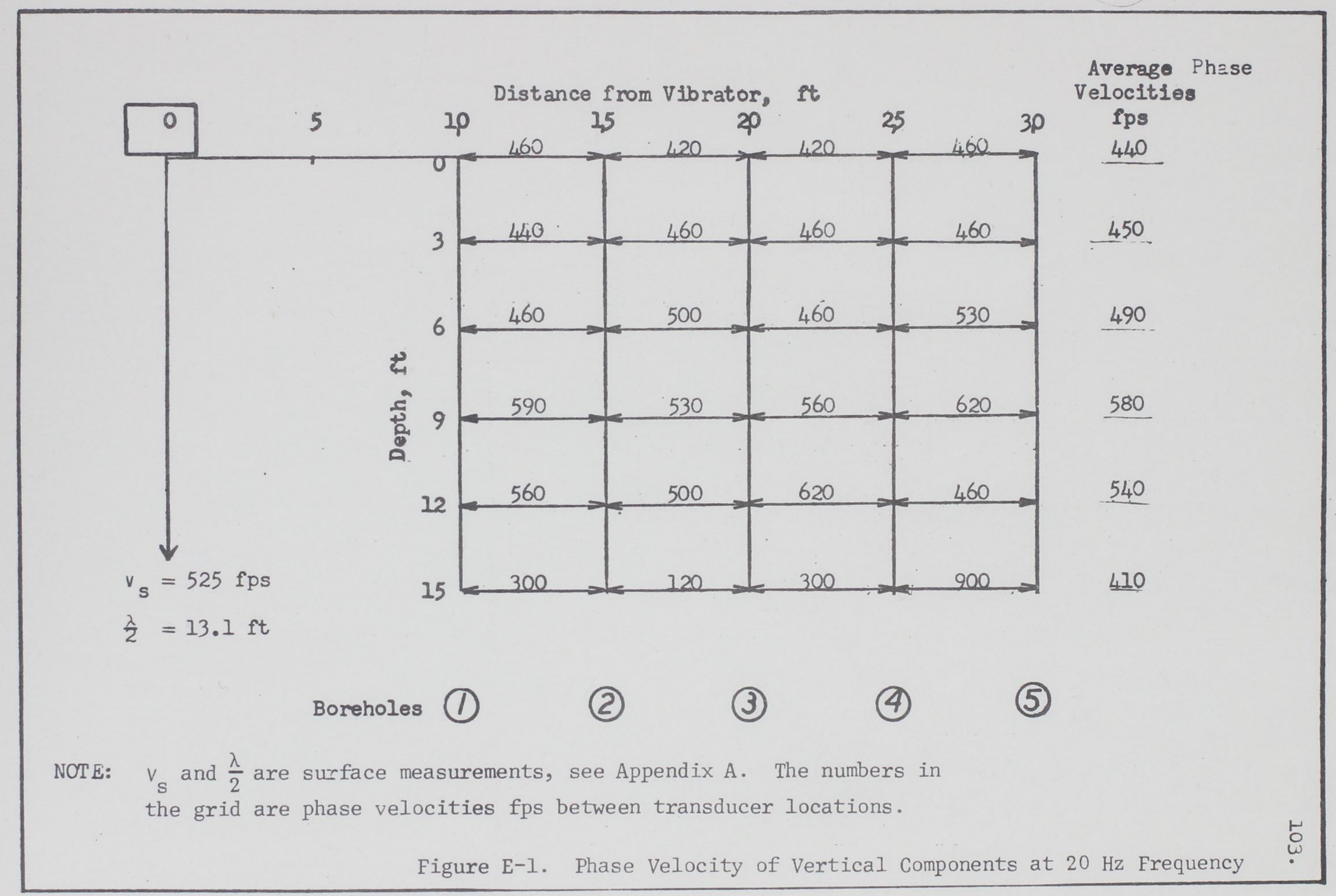




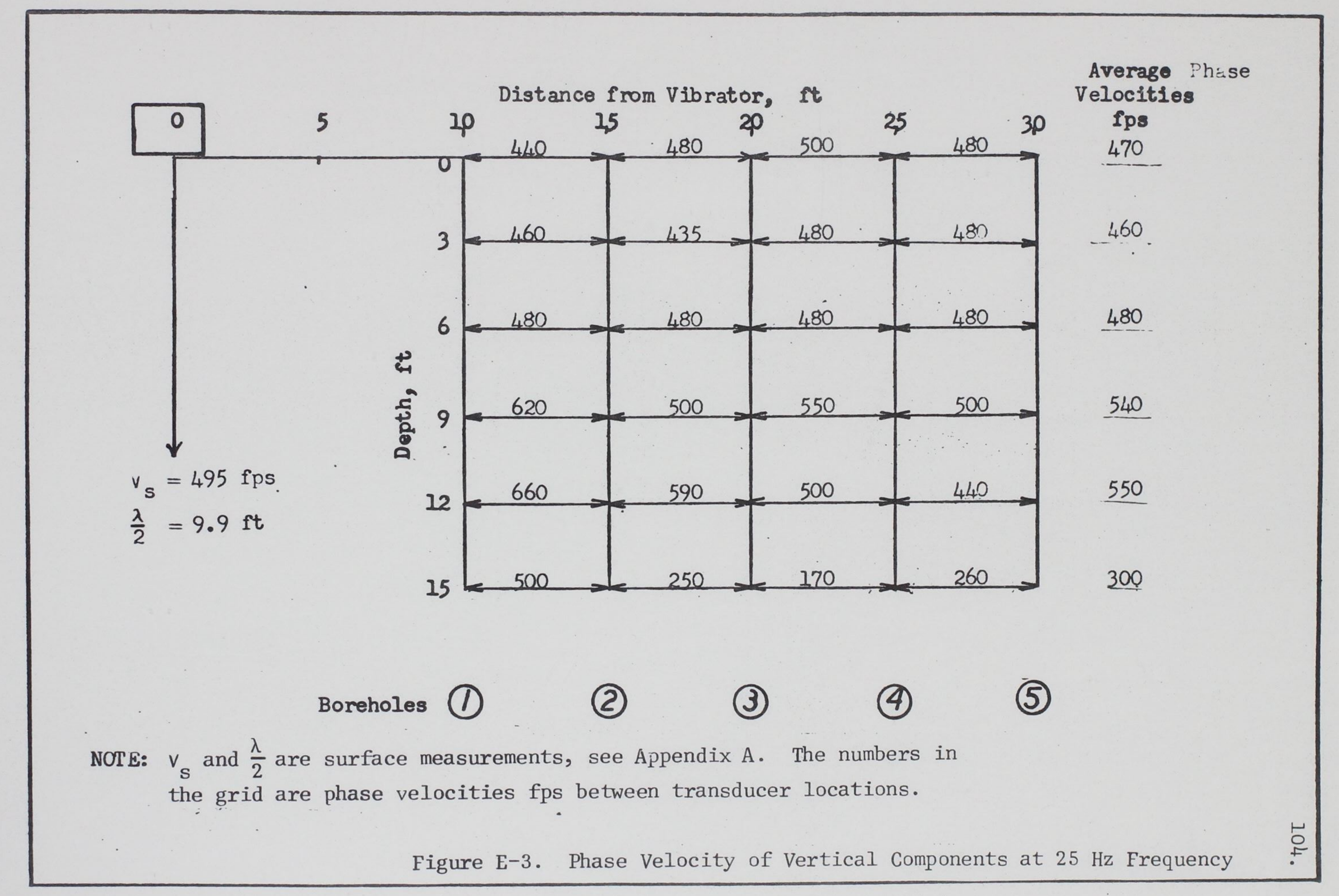




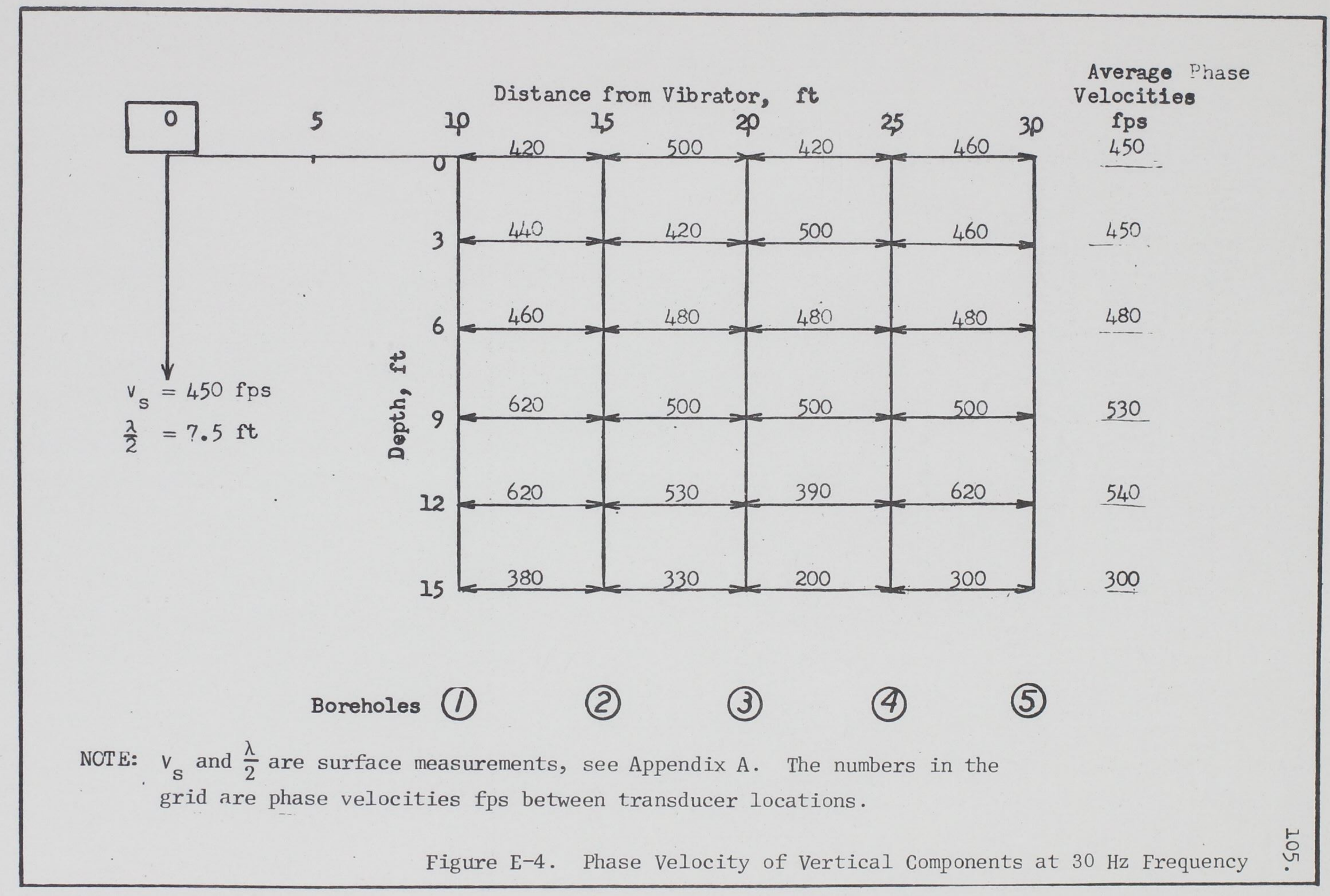




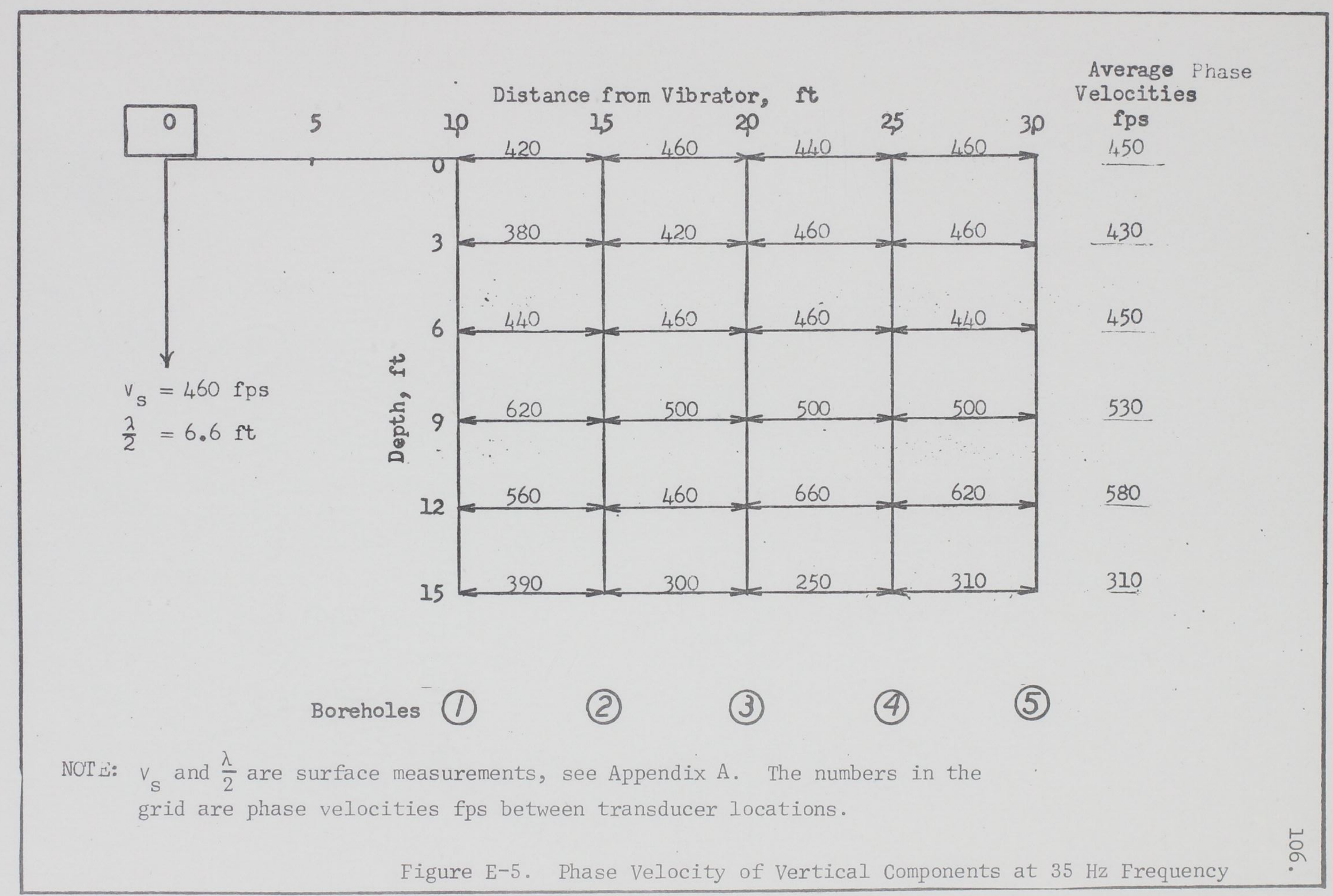




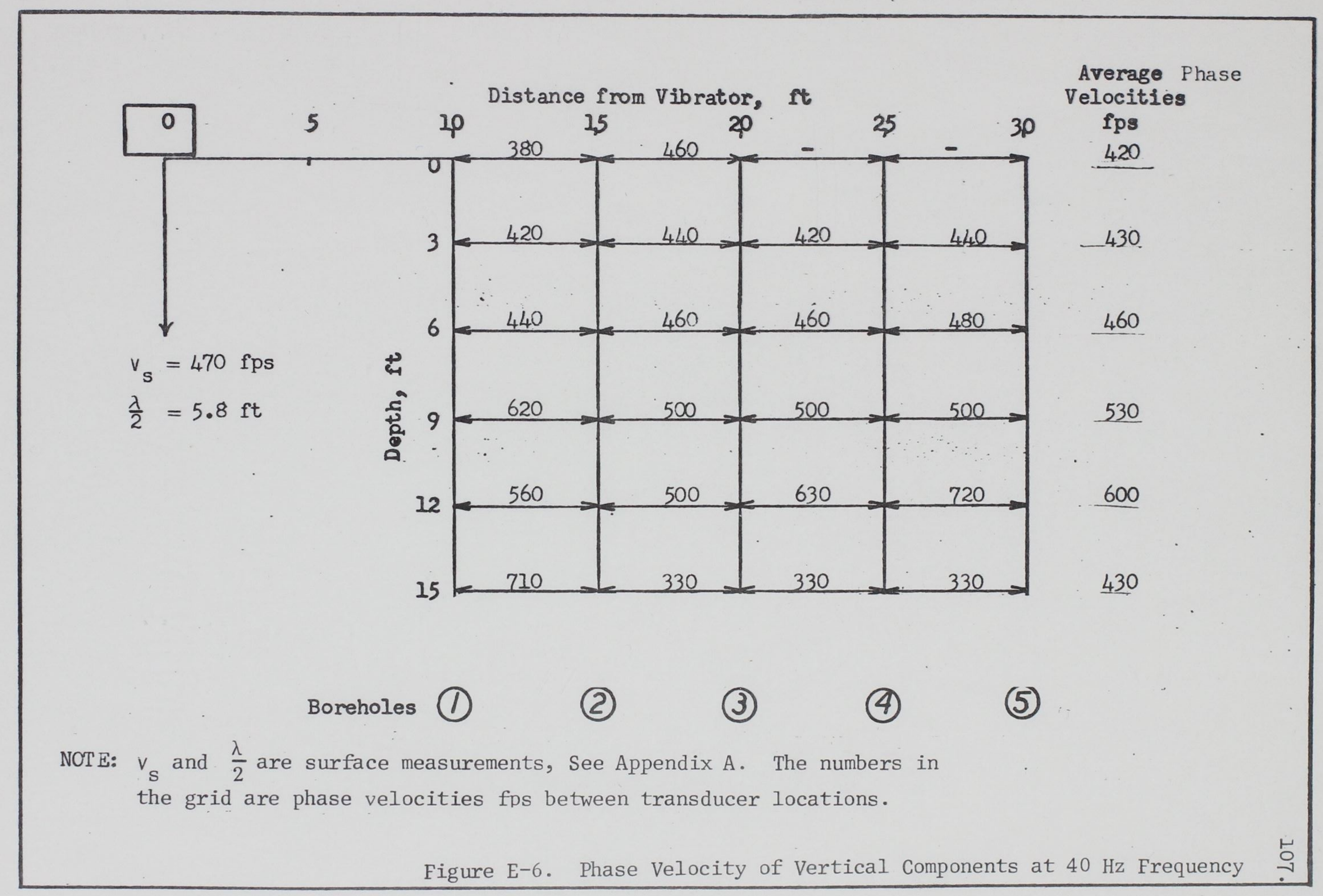



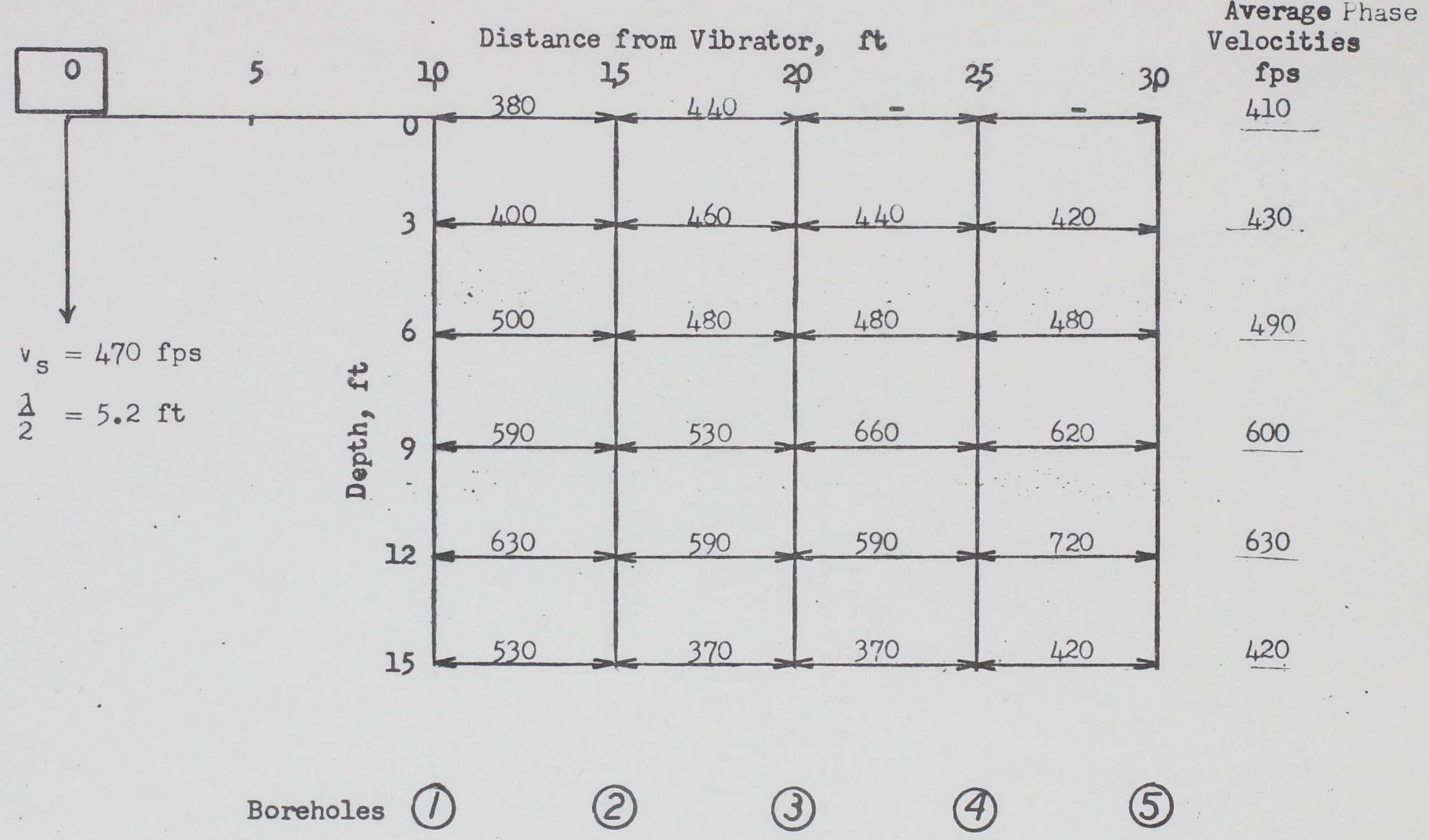

NOT $: v_{s}$ and $\frac{\lambda}{2}$ are surface m easurements, see Appendix A. The numbers in the grid are phase velocities fps between transducer locations. 


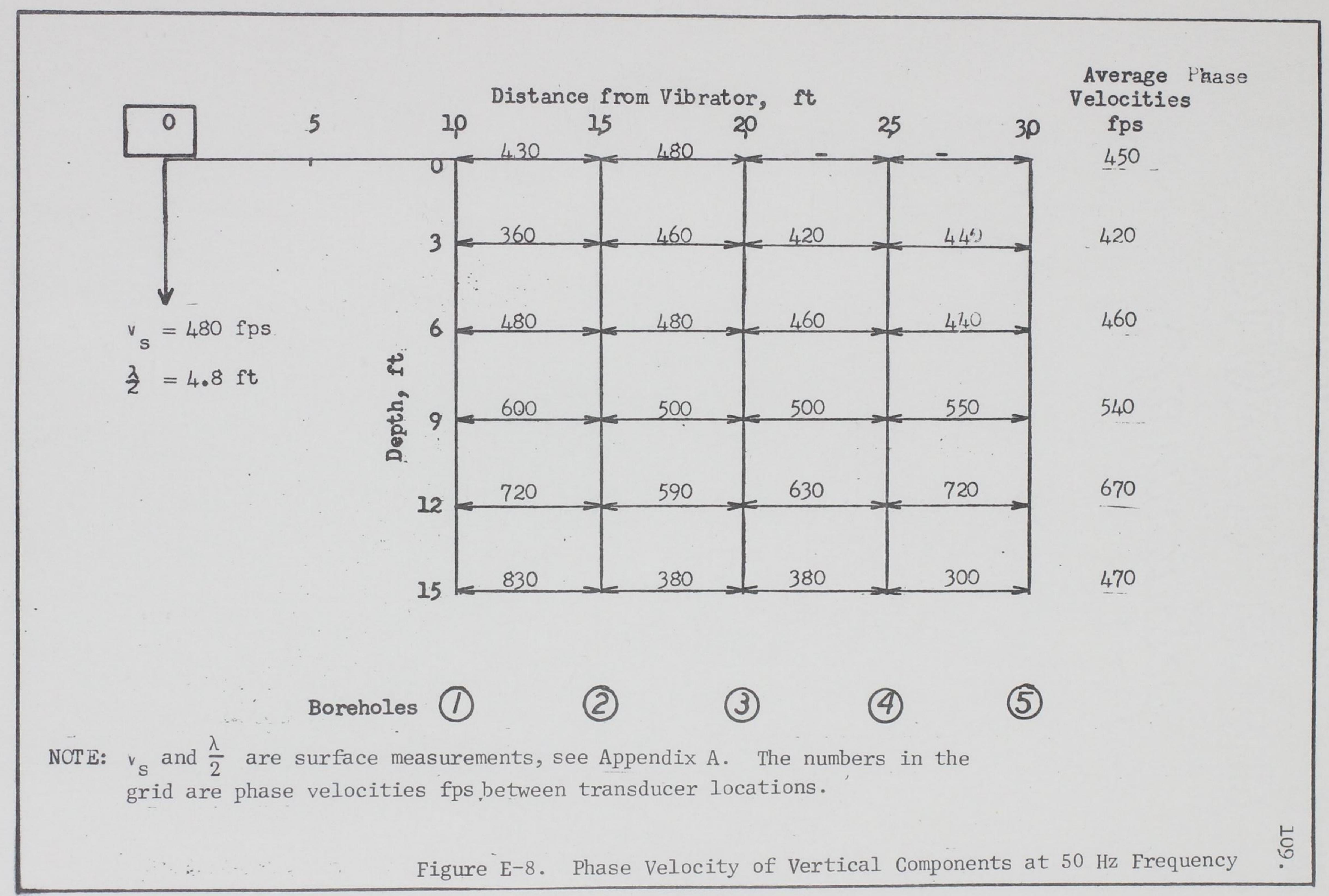


APPENDIX F

PLOTS OF PARTICLE VELOCITY AT VARIOUS DEPTHS 


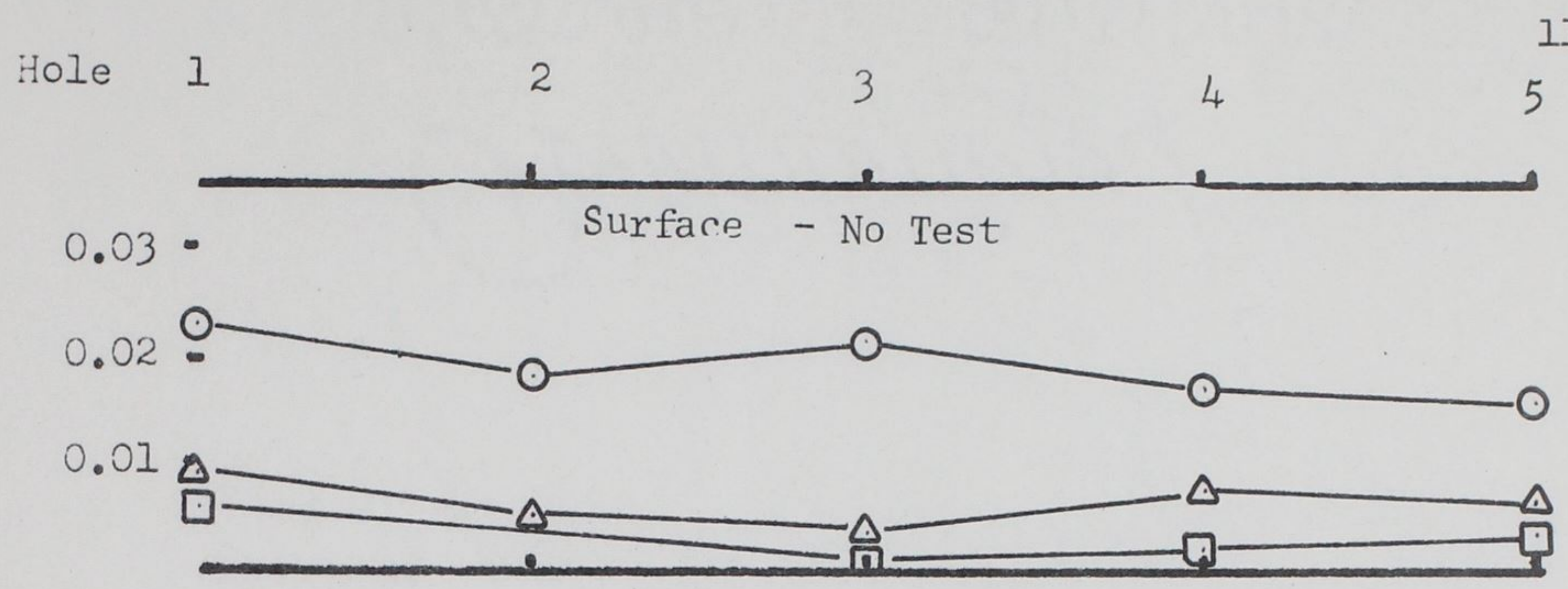

3 ft Depth - Test 32

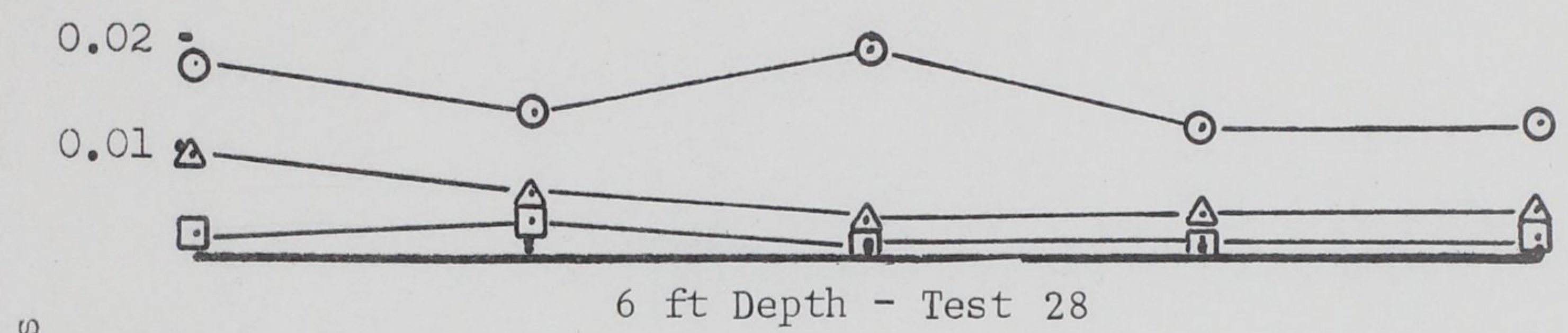

$\Omega_{n-4}^{-4}$

0.02

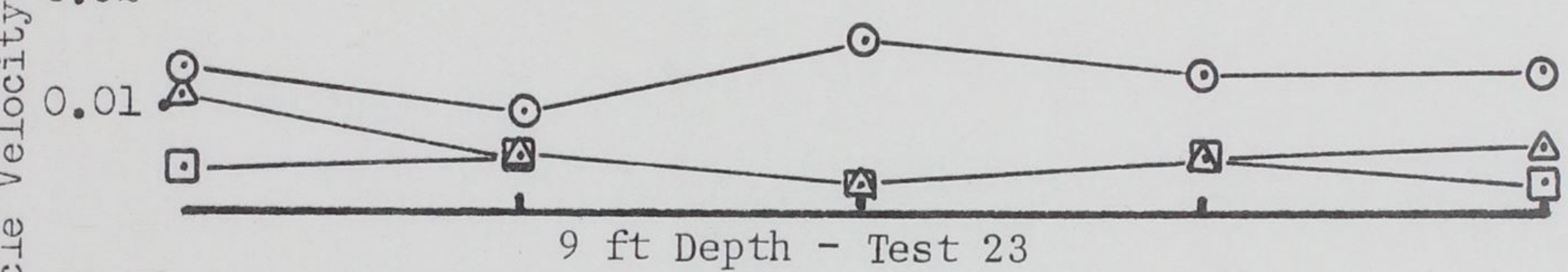

0.02

s.

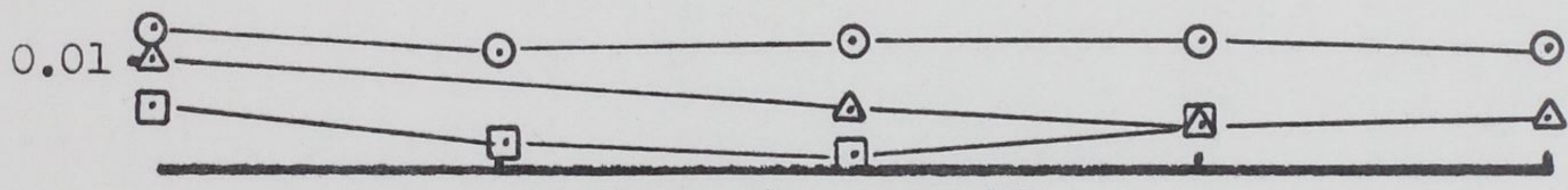

12 ft Depth - Test 19

$0.02=$

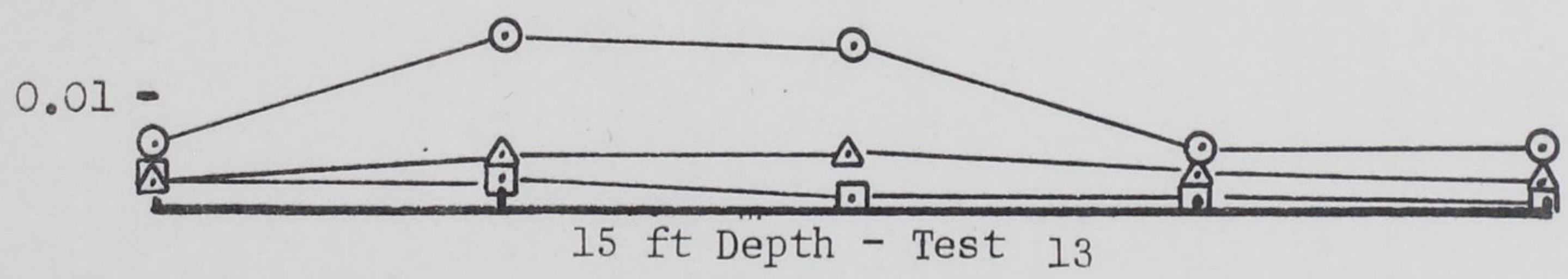

○ vertical

$\triangle$ radial

transverse

Note: Vibrator $10^{\prime}$ from hole 1

Force 882 It for a 11 tests

holes $5 \mathrm{ft}$ apart

Figure F-l. Particle Velocity at Various Depths Holes 1-5, Frequency $15 \mathrm{~Hz}$ 
Hole 1

$$
2
$$

$$
3
$$

4

๑vertical

Force 1568 lbs for all tests

○- holes $5 \mathrm{ft}$ apart

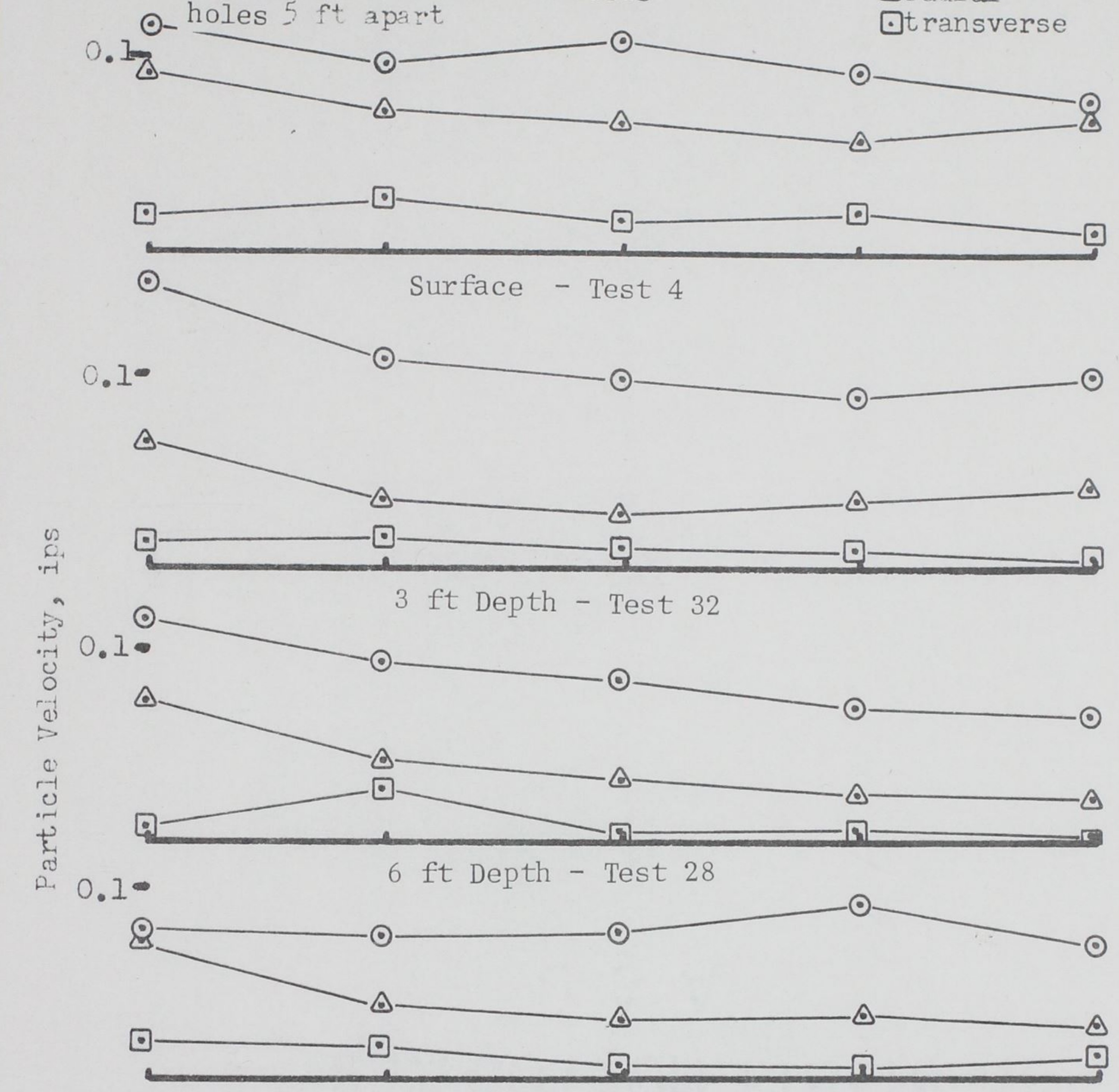

$\Delta$ radial

๑transverse

9 ft Depth - Test 23

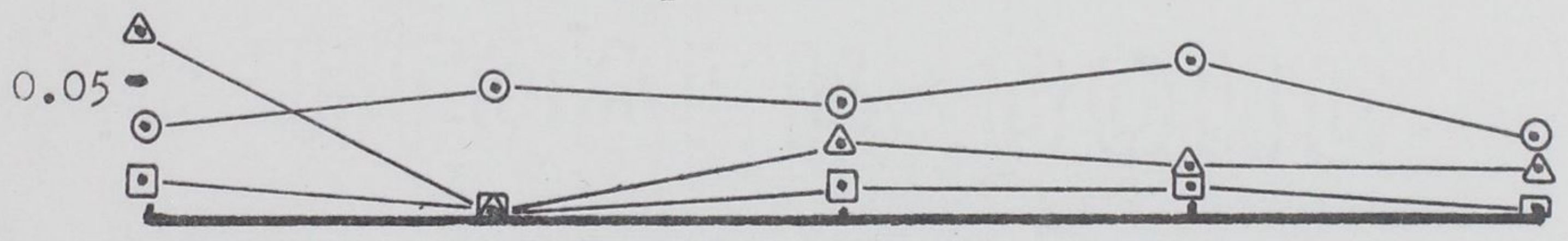

12 ft Depth - Test 19

0.05

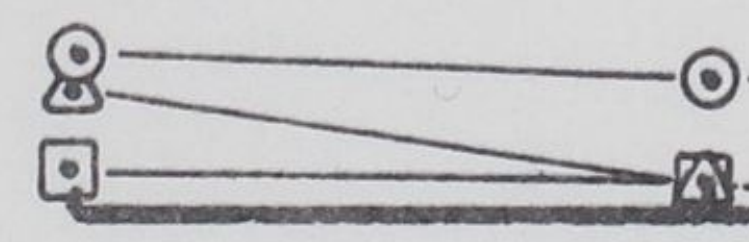

$15 \mathrm{ft}$ Depth - Test 13

Figure F-2. Particle Velocity at Various Depths Holes 1-5, Frequency $20 \mathrm{~Hz}$ 
liole
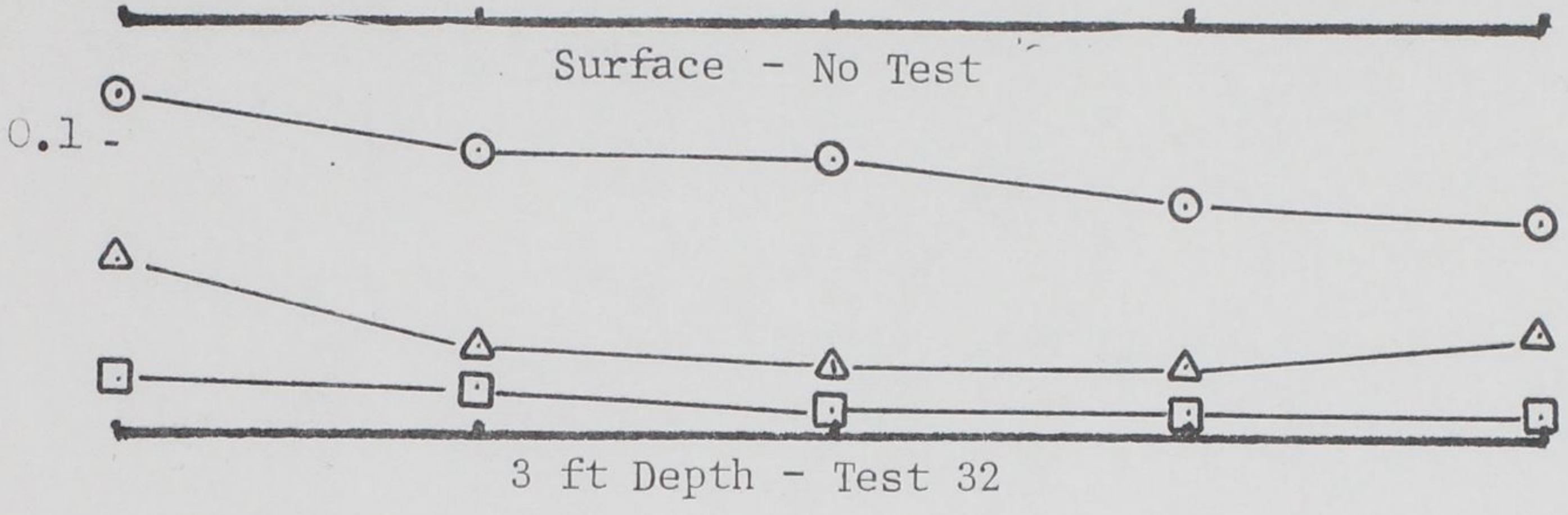

0.1

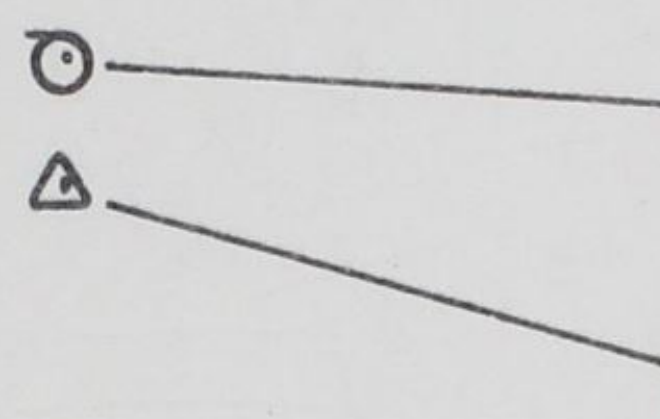

$\odot$
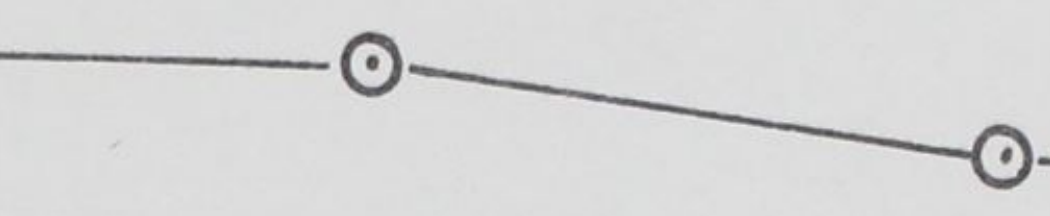

$\odot$

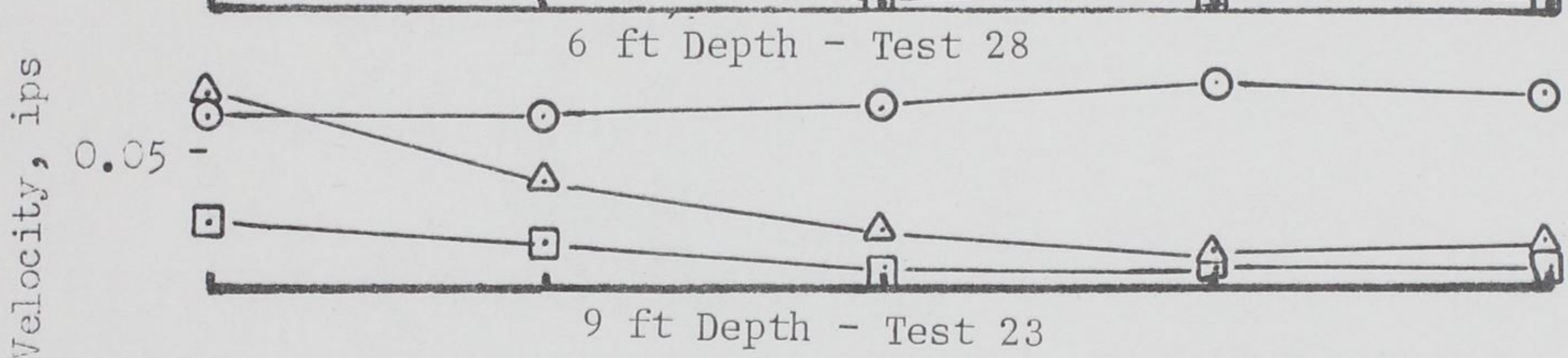

0.05
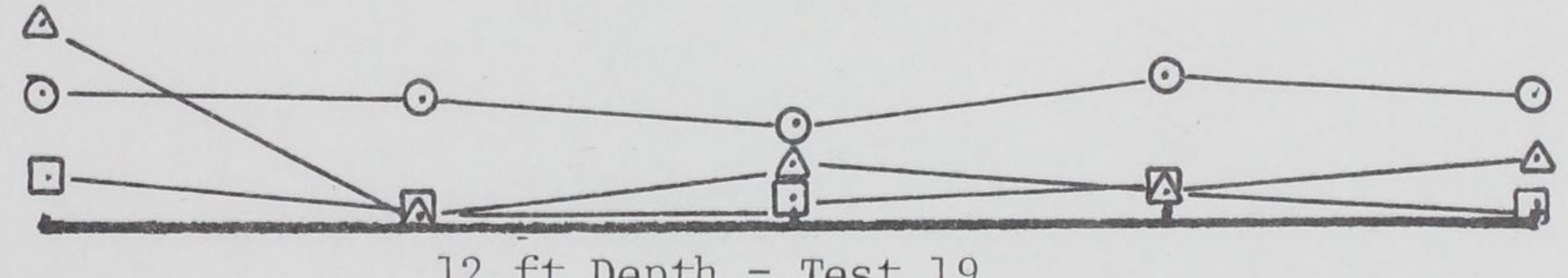

12 ft Depth - Test 19

0.05

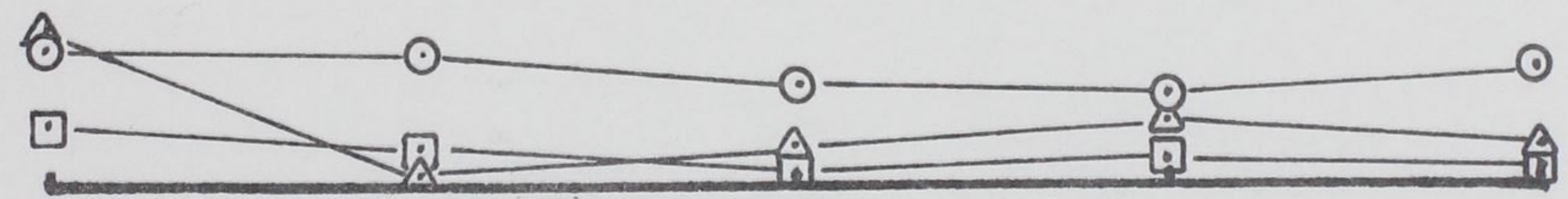

15 ft Depth - Test 13

○ vertical

$\triangle$ radial

ⓣransverse

Note: Vibrat or $10^{\prime}$ from hole 1. Force 2450 Ib for 2 71 tests holes $5 \mathrm{ft}$ apart

Figure F-3. Particle Velocity at Various Depths Holes 1-5, Frequency $25 \mathrm{~Hz}$ 


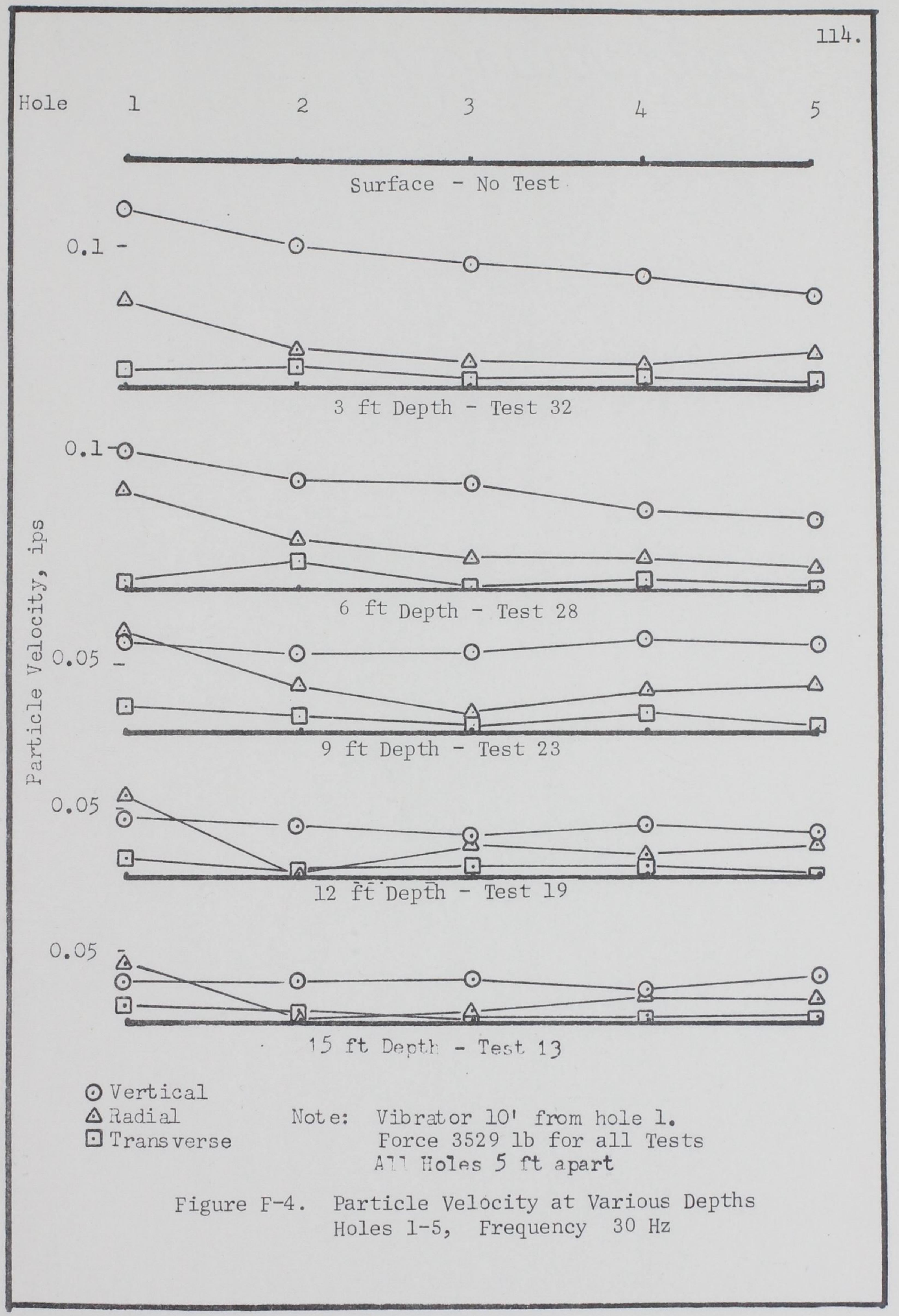




Hole $1 \quad 2 \quad 3 \quad 4 \quad 5^{115 .}$

Surfacé - No Test

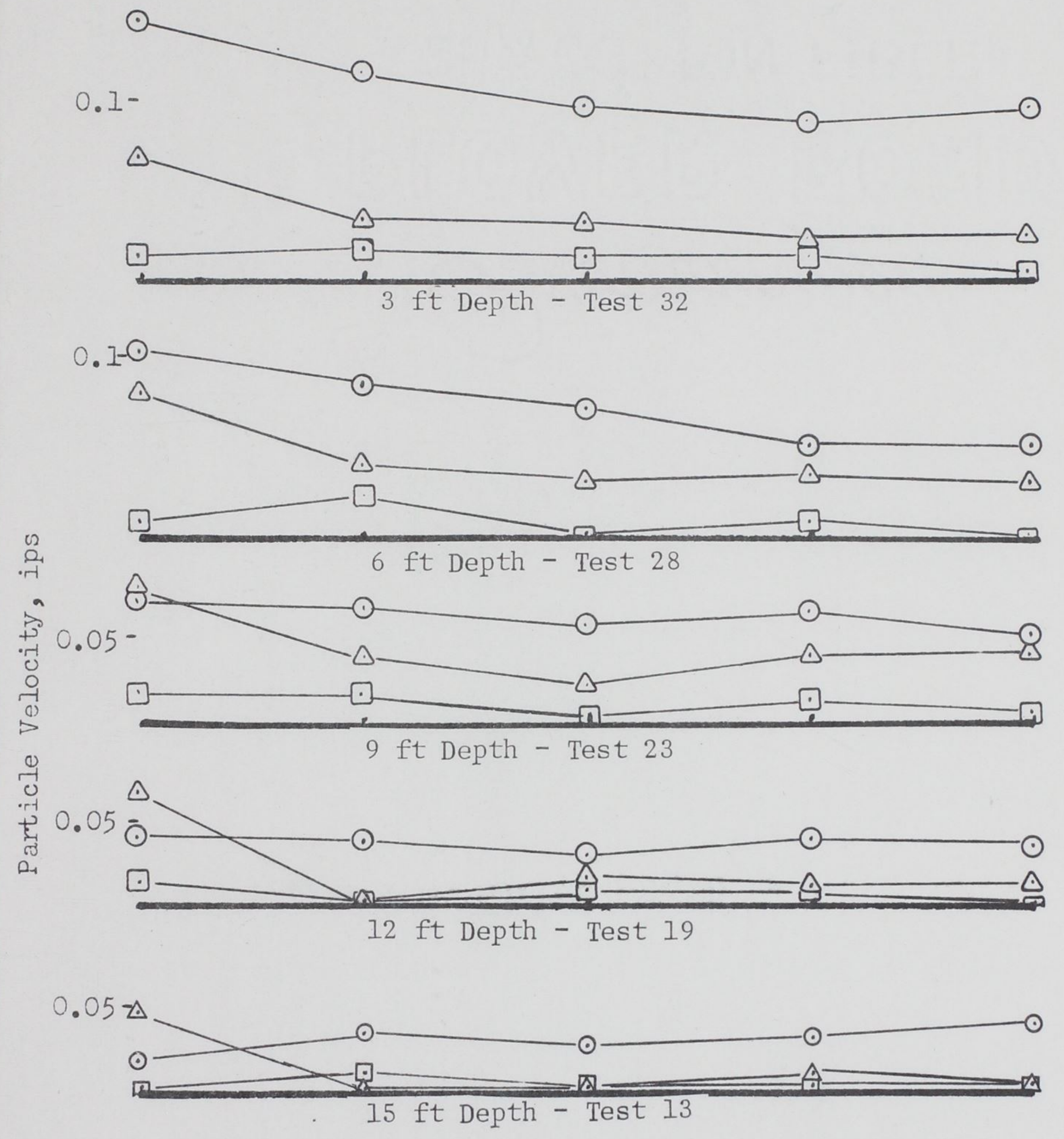

$\odot$ vertical

$\triangle$ radial Note: Vibrator 101 from hole 1.

transverse

Force $4802 \mathrm{lb}$ for all Tests All heles 5 ft apart

Figure F-5. Particle Velocity at Various Depths Holes 1-5, Frequency $35 \mathrm{~Hz}$ 
Hole 1

2

3
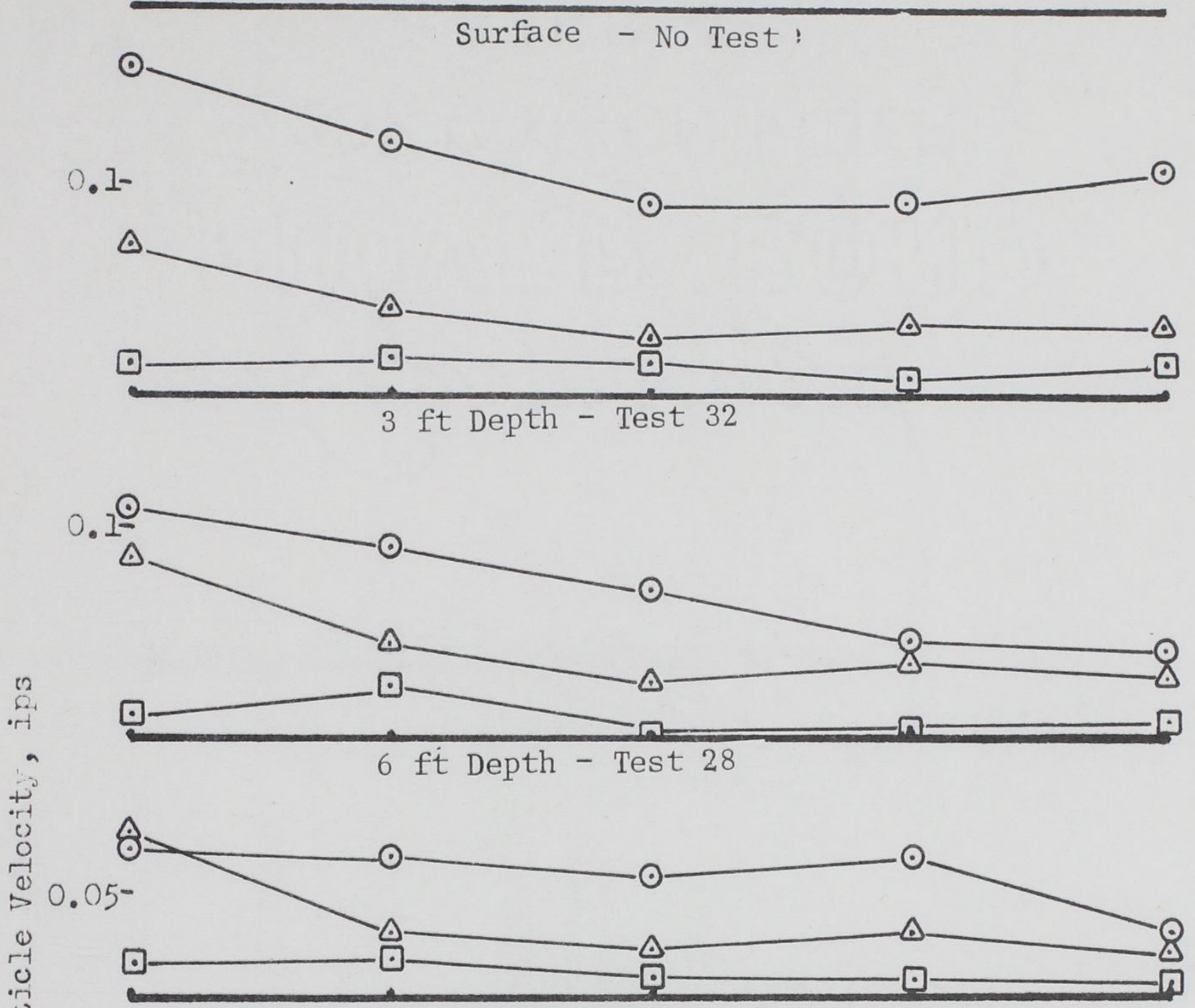

9 ft Depth - Test 23

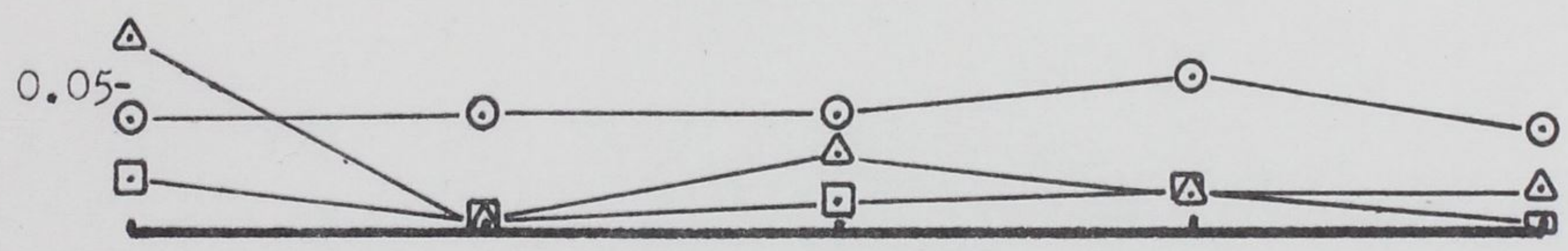

12 ft Depth - Test 19

$0.05-$

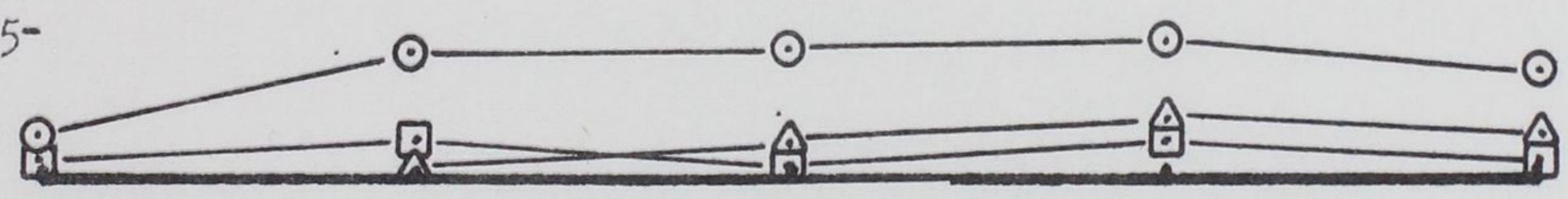

Overtical $15 \mathrm{ft}$ Depth - Test 13

Aradial Note: Vibrator 101 from hole 1.

Otransverse Force $6272 \mathrm{lb}$ for all Tests

All holes $5 \mathrm{ft}$ apart

Figure F-6. Particle Velocity at Various Depths Holes 1-5, Frequency $40 \mathrm{~Hz}$ 


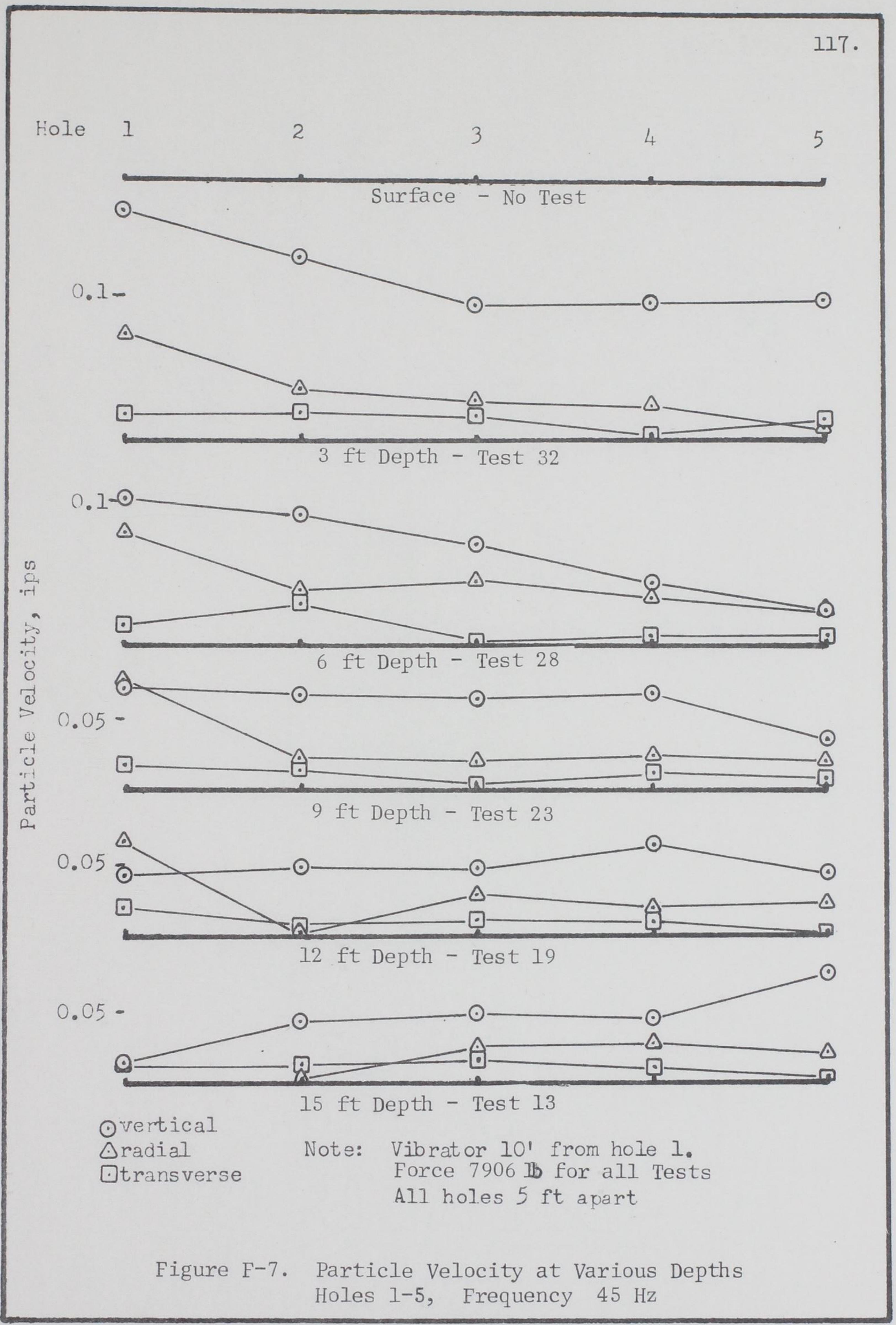




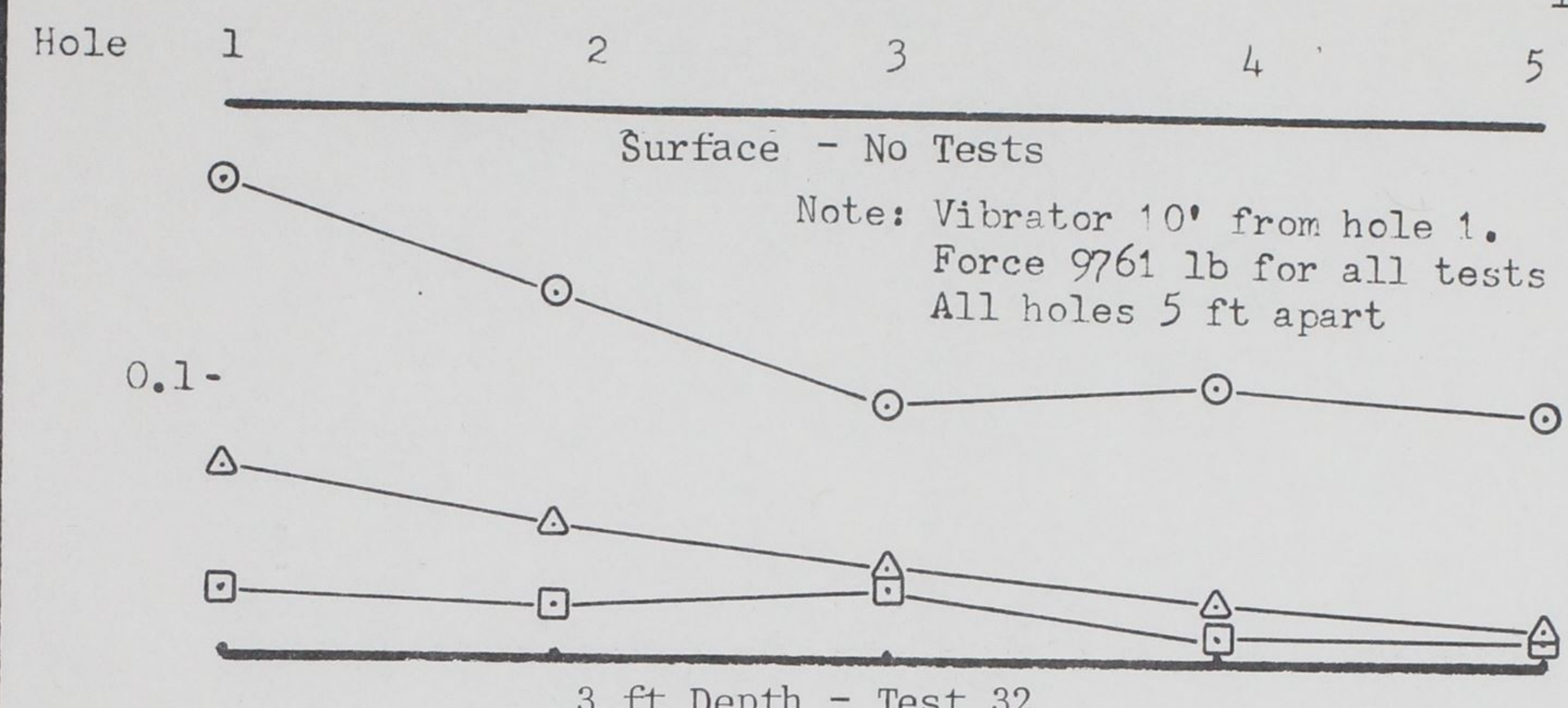

It Depth - Test 32
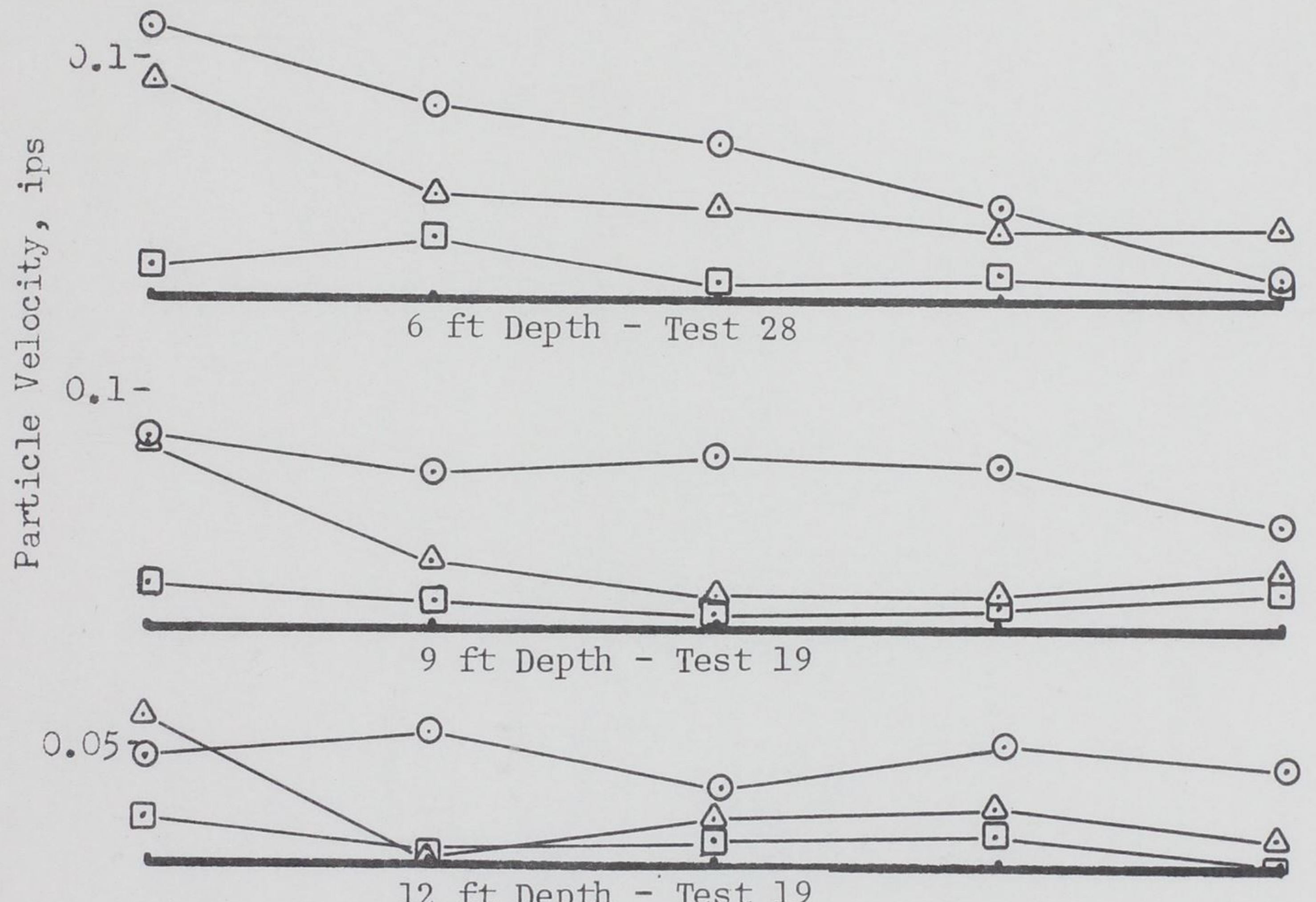

$12 \mathrm{ft}$ Depth - Test 19

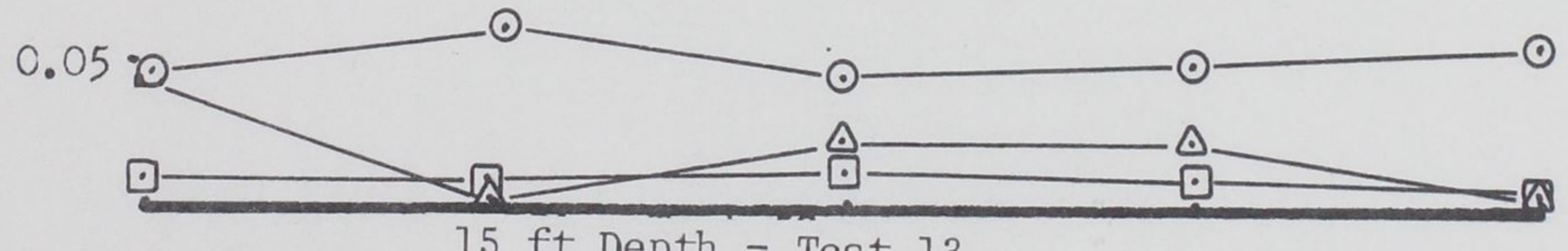

○ vertical

$15 \mathrm{ft}$ Depth - Test 13

$\Delta$ radial

๑transverse

Figure F-8. Particle Velocity at Various Depths 1 Holes 1-5, Frequency $50 \mathrm{~Hz}$ 


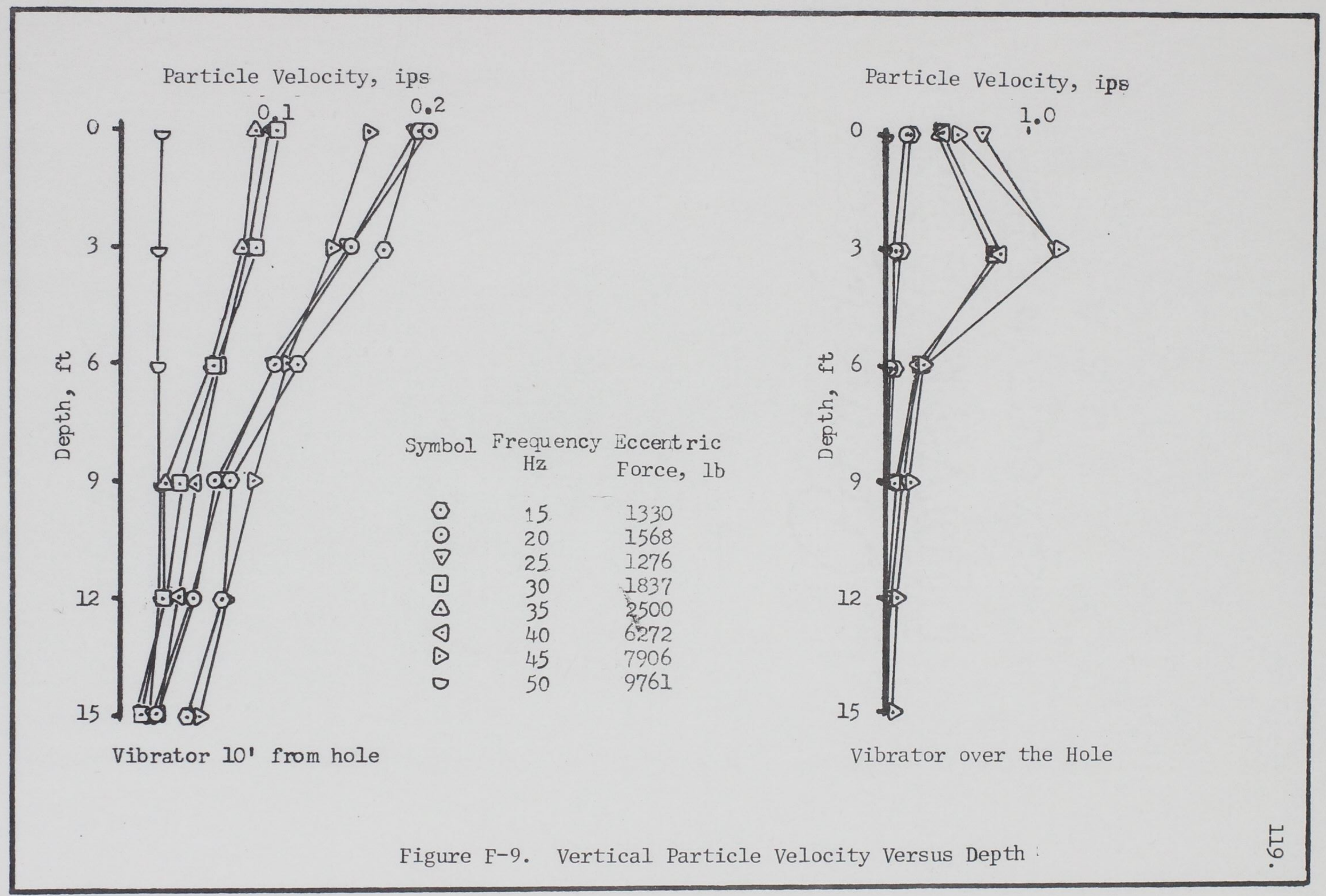


Particle Velocity, ips

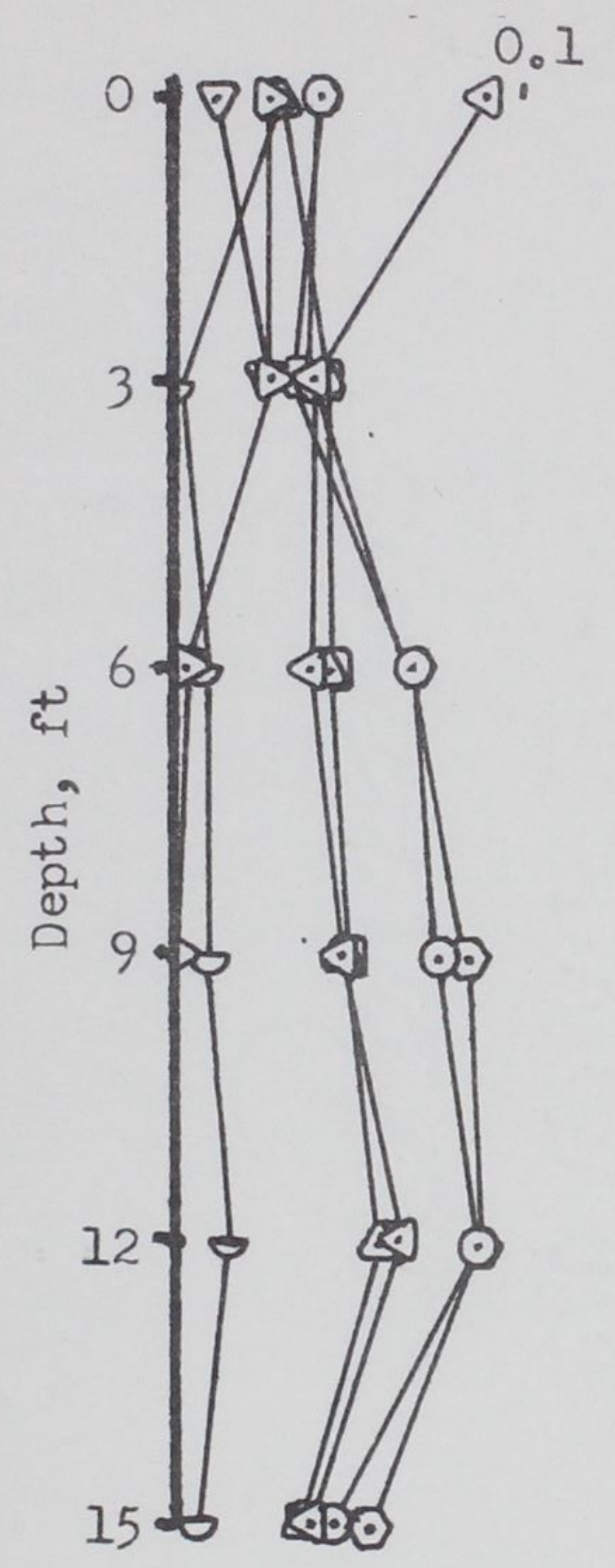

Vibrator $10^{\prime}$ from hole

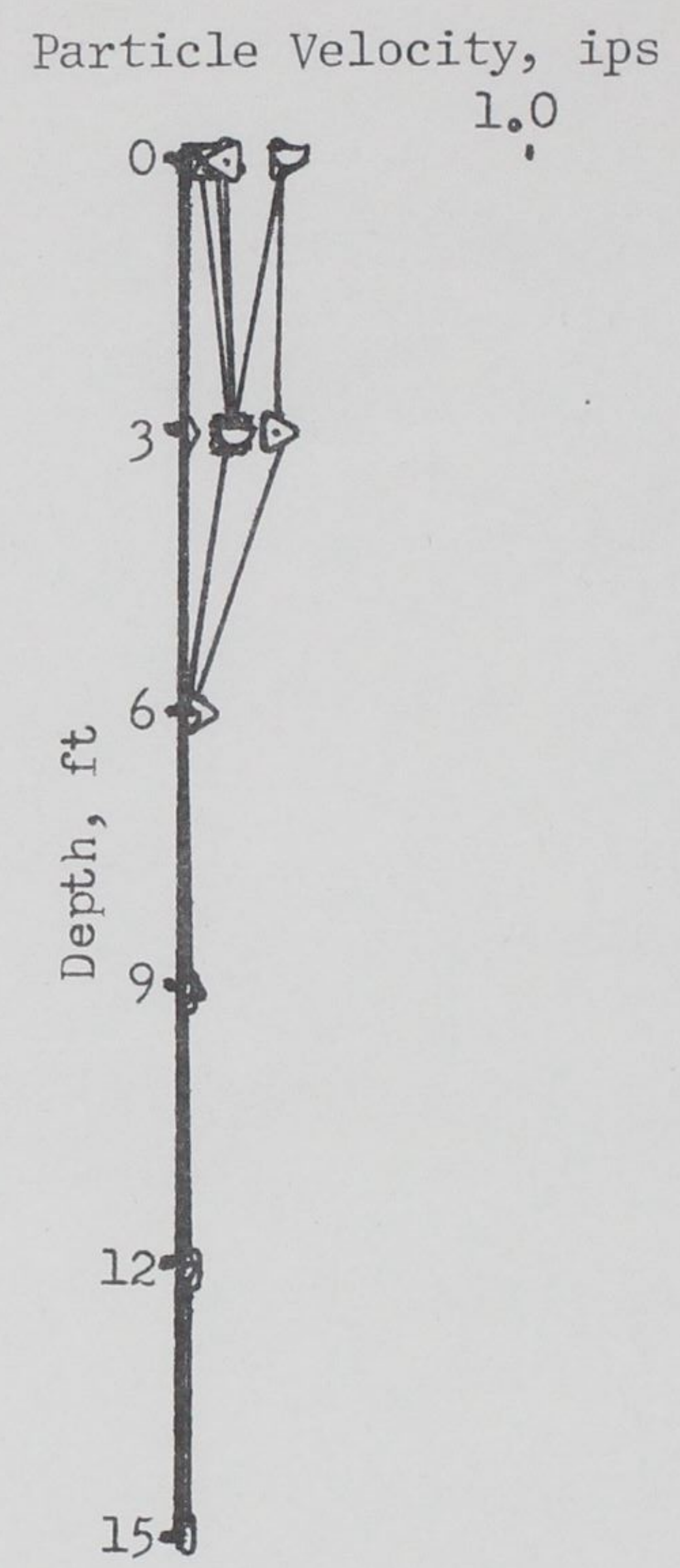

Vibrator over the Hole

Figure F-10. Radial Particle Velocity Versus Depth 


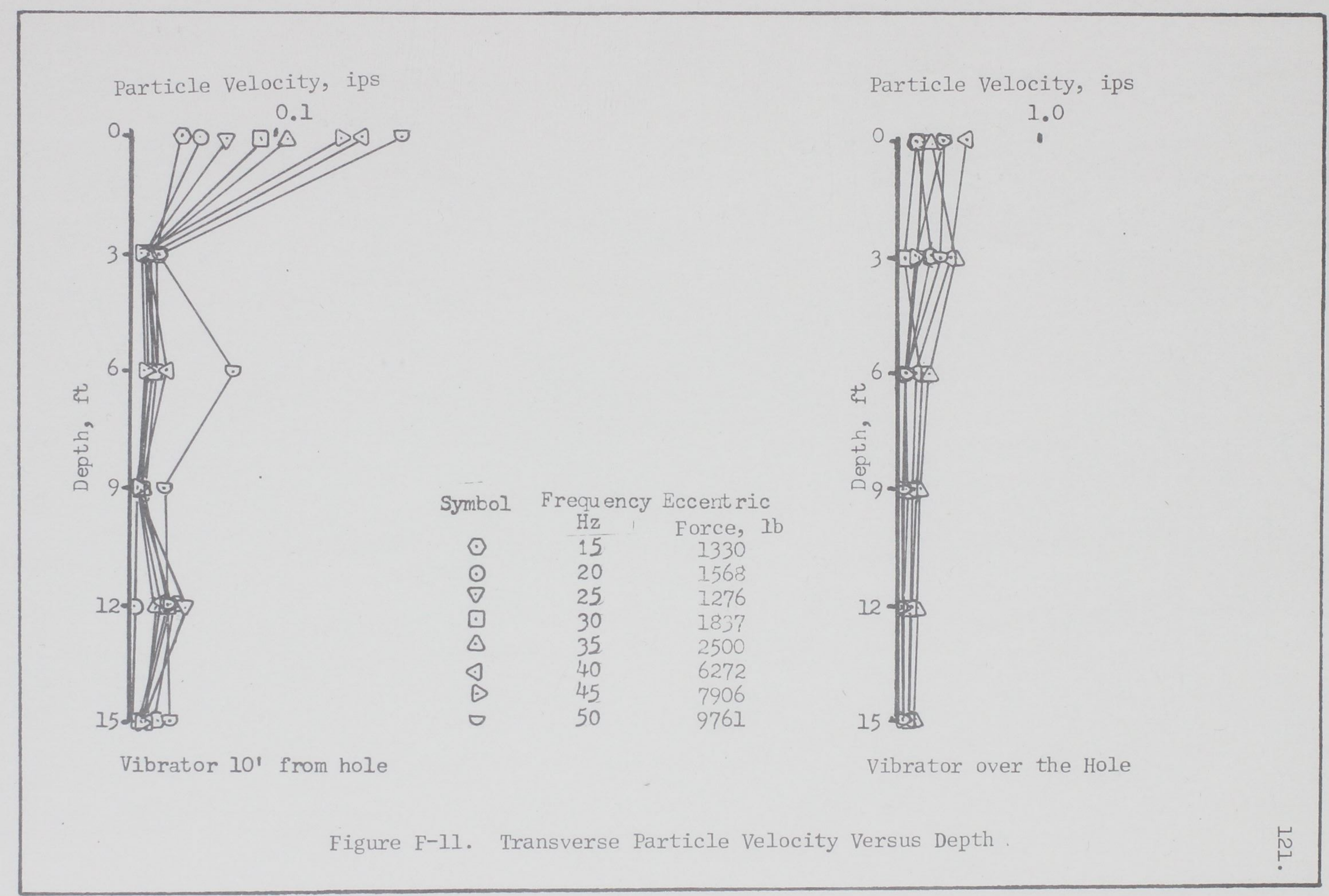




\section{REFERENCES AND BIBLIOGRAPHY}

\section{References}

1. Geophysical Specialties Company, Engineering Seismograph. 1961

2. U. S. Army, Chief of Engineers, Subsurface Investigation, Geophysical Explorations. EM 1110-2-1802, Vicksburg, Mississippi, 1948.

3. Heukelom, W., and Foster, C. R., "Dynamic Testing of Pavements." ASCE Soil Mechanics and Foundations Division Journal, Vol. 86, No. SMI, Part 1, New York, New York, pp. 1-28, 1960.

4. Heiland, C. A., Geophysical Exploration, Prentice-Hall, Inc., New York, New York, 1940.

5. Heukelom, W., Dynamic Testing of Pavements; Survey of Theoretical Considerations, Unpublished. 


\section{Bibliography}

1. Arnold, R. N., Bycroft, G. N., and Warburton, G. B., "Forced Vibrations of a Body on an Infinite Elastic Solid," J. Appl. Mech., Trans. ASME, Vol. 77, pp. 391-401, 1955.

2. Barkan, D. D., "Field Investigations of the Theory of Vibration of Massive Foundations under Machines," Proc. I ICSMFE (Harvard University, Cambridge, Mass.) Vol. II, pp. 285-288, 1936.

3. Heukelom, W., and Foster, C. R., "Dynamic Testing of Pavements," J. Soil Mech. and Found. Div., Proc. ASCE, Vol. 86 No. SMI, part 1 Feb., pp. 1-28, 1960.

4. Jones, R., "In Situ Measurement of the Dynamic Properties of Soil by Vibration Methods," Geotechnique, Vol. 8, No. l, Mar., pp. 1-2l, 1958 .

5. Lysmer, J., and Richart, F. E., Jr., "Dynamic Response of Footings to Vertical Loading," J. Soil Mech. and Found. Div., Proc. ASCE, Vol. 92, No. SM 1, Jan., pp. 65-91, 1966.

6. Reissner, E., and Sagoci, H. F., "Forced Torsional Oscillations of an Elastic Half-Space," J. of Appl. Phys. Vol. 15, pp. 652662,1944 .

7. Richart, F. E., Jr., and Whitman, R. V., "Comparis on of Footing Vibration Tests with Theory," J. Soil Mech. and Found. Div., Proc. ASCE, Vol. 93, No. SM 6, Nov., pp. 143-168, 1967.

8. Warburton, G. B., "Forced Vibration of a Body Upon an Elastic Stratum," J. Appl. Mech., Trans. ASME, Vol. 24, pp. 55-58, 1957. 


\section{DOCUMENT CONTROL DATA - R \& D}

(Security ciassification of title, body of abstract and indexing annotetion must be entered when the overall report is classified) 1. ORIGINATING ACTIVITY (Corporate author)

U. S. Army Engineer Waterways Experiment Station

Vicksburg, Mississippi

2a. REPORT SECURITY CLASSIFICATION Unclassified

2b. GROUP

\section{REPORT TITLE}

AN EVALUATION OF AN EXISTING PROCEDURE FOR DETERMINING SHEAR MODULI AT DEPTHS BY IN SITU VIBRATORY TECHNI QUE

\section{DESCRIPTIVE NOTES (TYPe of report and inclusive dates)}

Final report

5. AUTHOR(S) (First name, middle initial, last name)

Jack Fowler

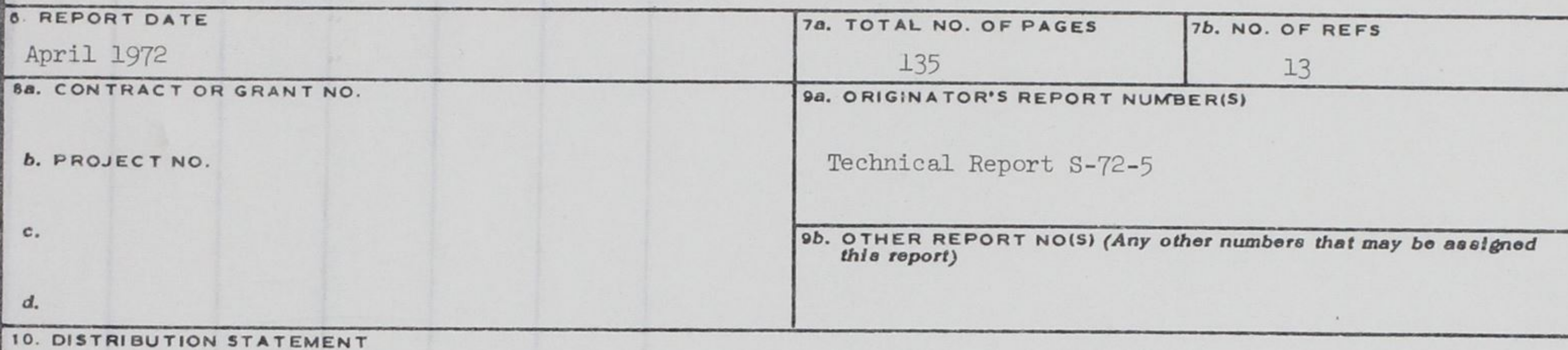

Approved for public release; distribution unlimited.

\section{SUPPLEMENTARY NOTES Report was also submitted}

to Mississippi State University, State College,

Mississippi, as thesis for degree of Master of

Science in Civil Engineering

13. ABSTRACT The Corps of Engineers has been determining the dynamic characteristic of soil and pavement systems by the use of surface-induced vibrations for approximately 10 years. This non-destructive vibratory technique is utilized by all federal agencies involved in planning the design of space-craft launch and operation facilities, antiballistic missile sites, heavy weapons, air field and road construction, radar towers or structures to house delicate electronic equipment when accurate and quick information pertaining to the ability of the soils to resist deformation is required. The Corps of Engineers has been actively en gaged in improving and developing equipment and procedures for determining the elastic moduli (and thus the resistance to deformation) of foundation soils by vibratory techniques. The basic theory assumes that the Rayleigh waves generated by the vertical oscillations of a vibrator on the soils surface are for all practical purposes considered to be shear-waves. When the waves are propagated at a known frequency, the wave velocity is determined by the product of the wavelength and frequency. The shear-wave velocity propagation is assumed to take place within a depth equal to about one half the wavelength. The purpose of this investigation was to validate the existing theory by determining shear moduli from the displacements, velocities, frequencies, phase relationship, and wave shape characteristics recorded versus distance and depth from a vibratory source placed on the ground surface. Specifically to evaluate the concept that the surface wave propagates through a depth about equal to one half the wavelength. The results of this investigation indicated that the test section represented a fairly homogeneous elastic half-space which causes very little dispersion of a vibrating wave. Phase velocity measurements determined from surface and subsurface transducers were in excellert agreement. The conventional and dynamic laboratory and field tests of the soil fro the site also indicated that the soil represented a homogeneous elastic half-space. The data collected offered no explanation or proof to support the theory that surface waves penetrate the soil for a depth equal to one half the wavelength. It was concluded from the analysis of the existing concept, that the surface wave propagates through a depth approximately equal to half the wavelength cannot be verified from tests of a homogeneous medium where there is practically no dispersion of the wave. It was also concluded, however, that the vibratory technique does provide a reliable description of the subsurface condition and that the ac curate values of in situ moduli of the medium should be used in conjunction with conventional soils exploration and laboratory tests for the design of foundations subjected to dynamic loads. It was recommended that similar tests be conducted on test sections that would include more dispersive soil materials or layered systems. Additional information from similar tests would be beneficial in verifying the present procedures for determining in situ soil characteristics. 
Unclassified

Security Classification

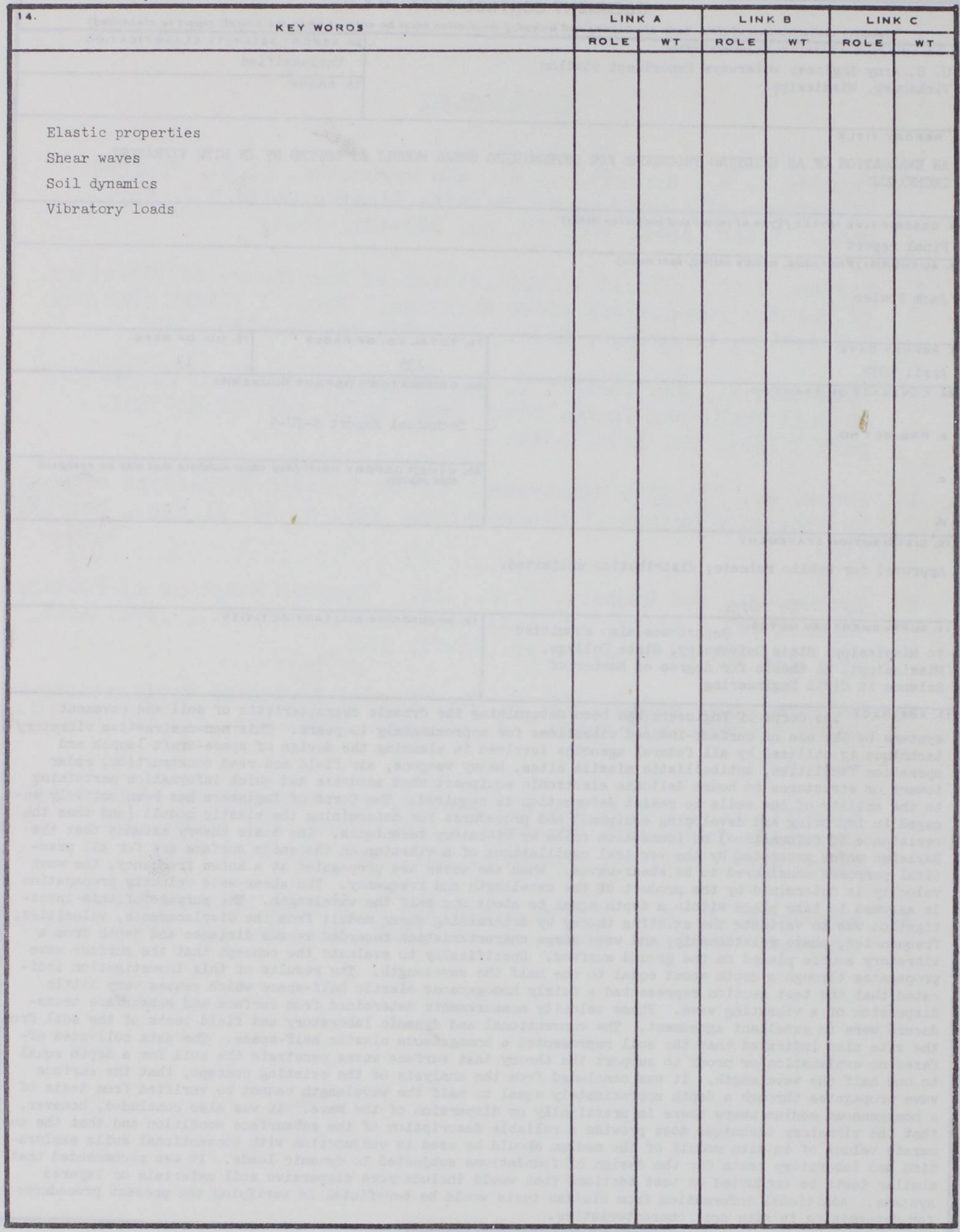

Unclassified 